US Army Corps

of Engineers ${ }_{\circledast}$

Engineer Research and

Development Center

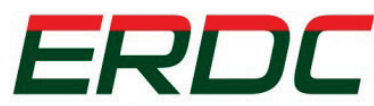

INNOVATIVE SOLUTIONS for a safer, better world

Wetlands Regulatory Assistance Program

\title{
Operational Draft Regional Guidebook for the Rapid Assessment of Wetlands in the North Slope Region of Alaska
}

Jacob F. Berkowitz, Nathan R. Beane, Kevin D. Philley,

and Matt Ferguson
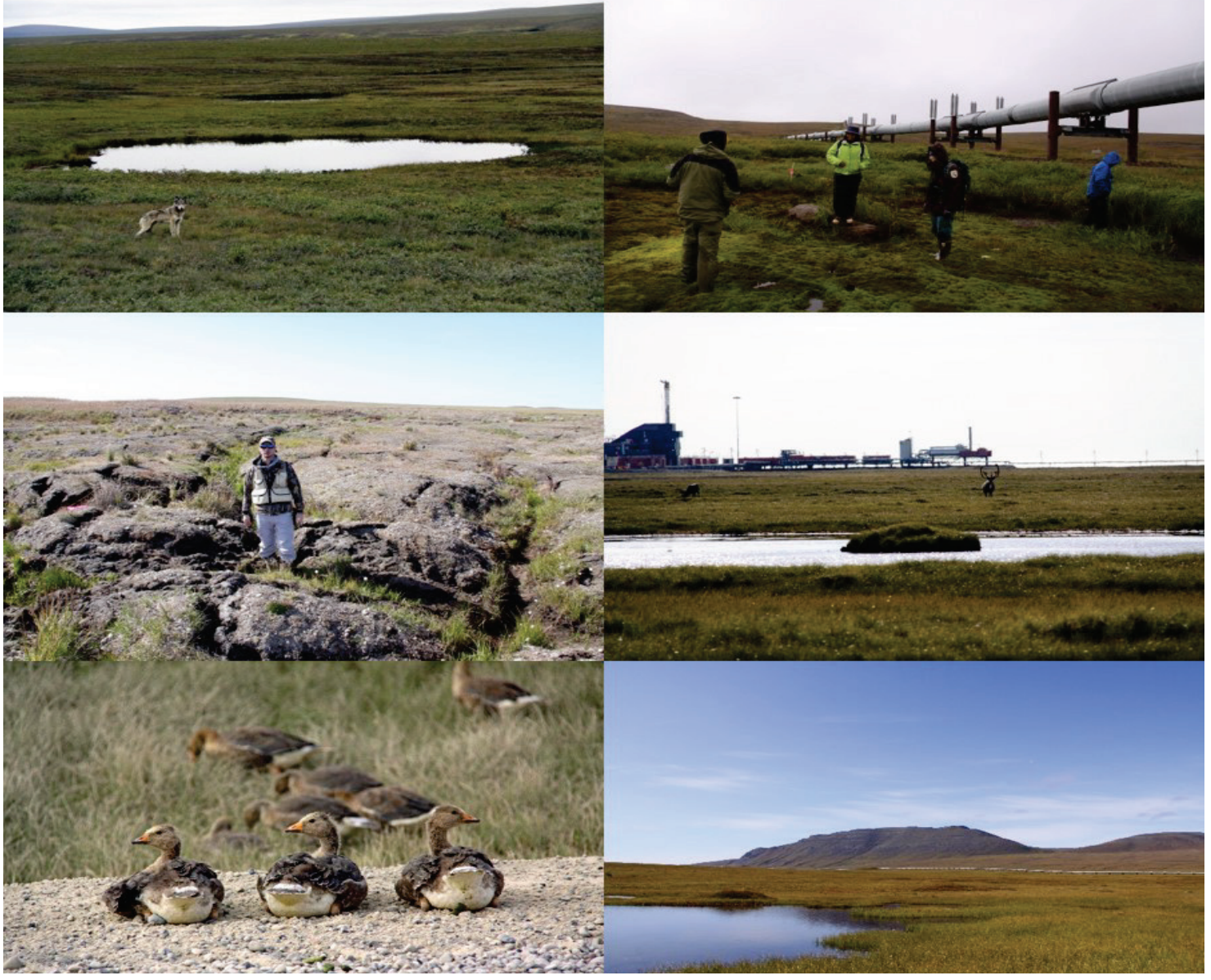
The U.S. Army Engineer Research and Development Center (ERDC) solves the nation's toughest engineering and environmental challenges. ERDC develops innovative solutions in civil and military engineering, geospatial sciences, water resources, and environmental sciences for the Army, the Department of Defense, civilian agencies, and our nation's public good. Find out more at www.erdc.usace.army.mil.

To search for other technical reports published by ERDC, visit the ERDC online library at http://acwc.sdp.sirsi.net/client/default. 


\section{Operational Draft Regional Guidebook for the Rapid Assessment of Wetlands in the North Slope Region of Alaska}

Jacob F. Berkowitz, Nathan R. Beane, and Kevin D. Philley

U.S. Army Engineer Research and Development Center

Environmental Laboratory

3909 Halls Ferry Road

Vicksburg, MS 39180

Matt Ferguson

U.S. Army Corps of Engineers, Alaska District

$22043^{\text {rd }}$ Street

JBER, AK 99506-0898

Final report

Approved for public release; distribution is unlimited.

Prepared for U.S. Army Corps of Engineers

Washington, DC 20314-1000

Under Work Unit A1210-North Slope Alaska 


\section{Abstract}

This guidebook describes a rapid approach to assessing wetlands within the Arctic Foothills and Arctic Coastal Plain (North Slope) region of Alaska. This report utilized established approaches to (1) characterize regional wetlands, (2) provide the rationale used to determine assessment scores, (3) describe assessment variables utilized, (4) outline the developed assessment equations, and (5) provide a step-by-step protocol for applying results. The region's remote nature and short growing season limits the time period during which on-site data can be collected. As a result, the developed method allows for a tiered approach utilizing (1) an assessment based upon off-site data (remotely sensed or desktop resources) only or (2) an assessment using a combination of on-site (field data collection) and off-site data collection. On-site data collection may be required at the discretion of USACE. Several scenarios are presented to aid users in conducting the rapid wetland assessment.

DISCLAIMER: The contents of this report are not to be used for advertising, publication, or promotional purposes. Citation of trade names does not constitute an official endorsement or approval of the use of such commercial products. All product names and trademarks cited are the property of their respective owners. The findings of this report are not to be construed as an official Department of the Army position unless so designated by other authorized documents. 


\section{Contents}

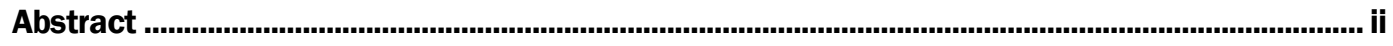

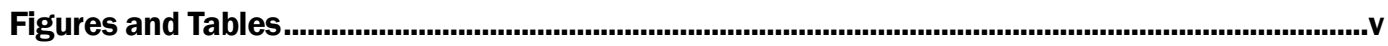

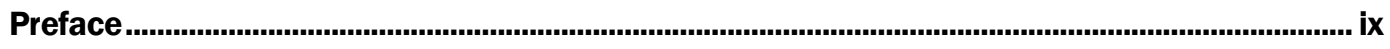

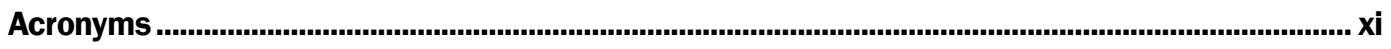

1 Characterization of Regional Wetland Subclasses for North Slope Alaska............................ 1

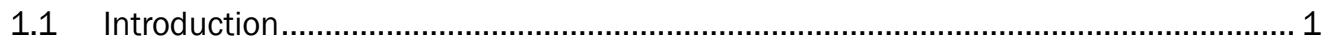

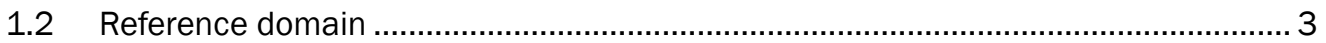

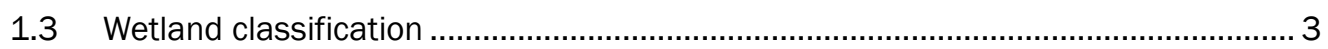

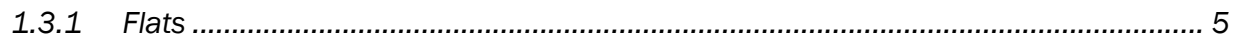

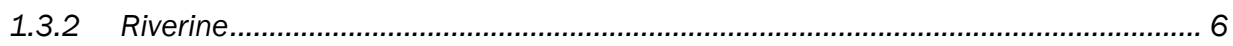

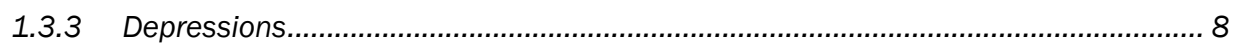

1.3.4 Fringe (e.g., lacustrine, tidal, and vegetated shallows)........................................... 8

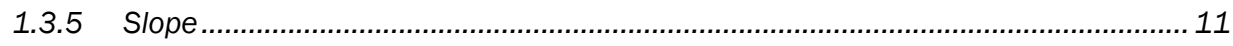

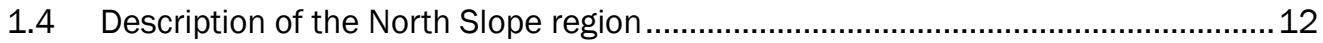

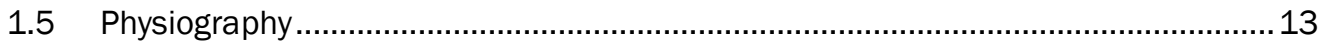

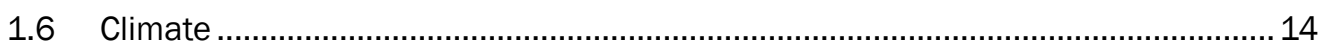

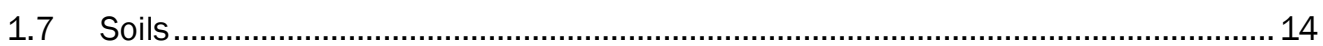

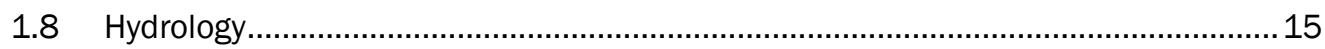

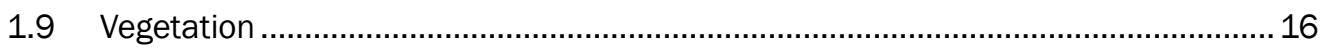

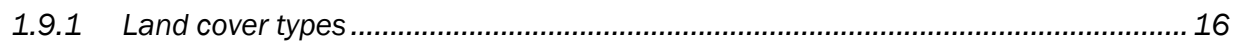

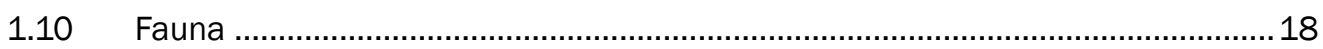

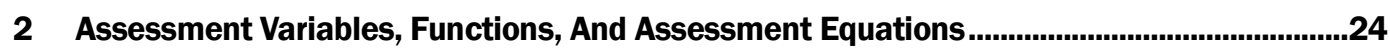

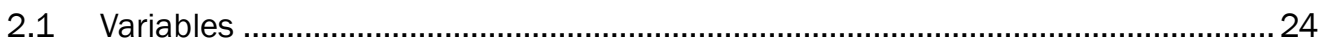

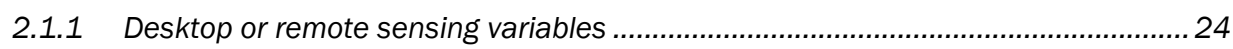

2.1.2 On-site variables........................................................................................................ 26

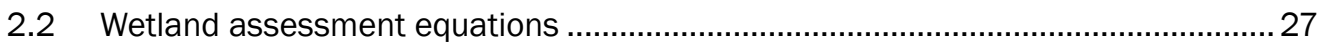

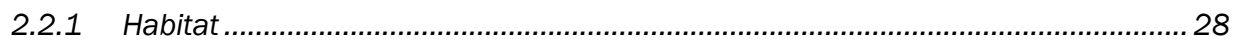

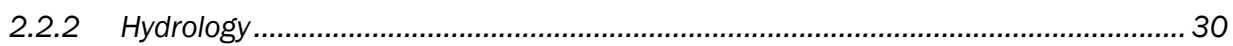

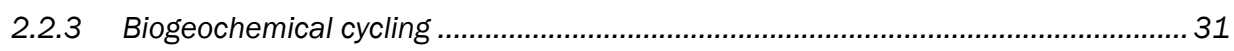

2.3.4 On-site assessment score modifier....................................................................... 34

2.3.5 Dust deposition and the presence of thermokarst ............................................. 34

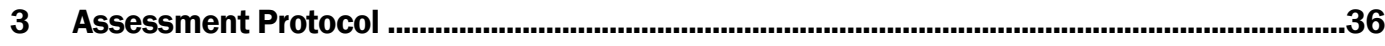

3.1 Desktop or remote sensing variable protocol .........................................................38

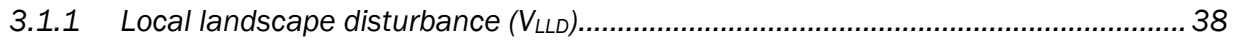

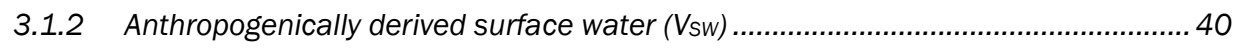

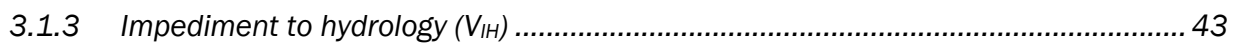

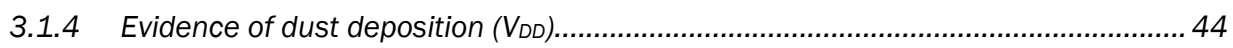




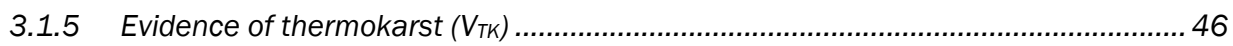

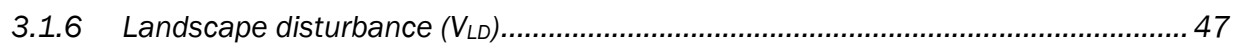

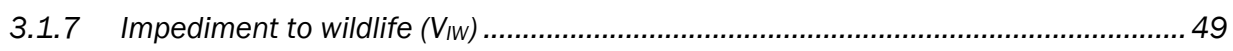

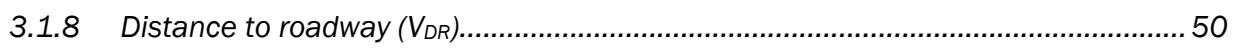

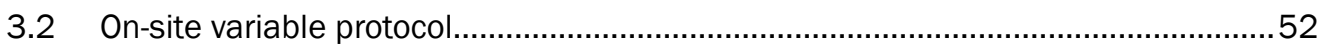

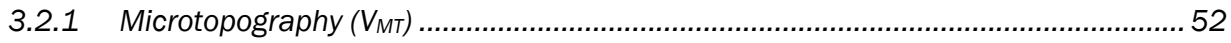

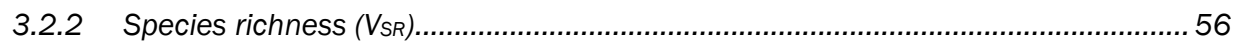

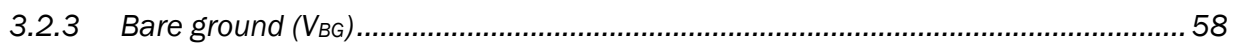

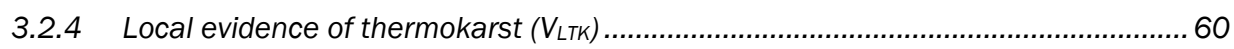

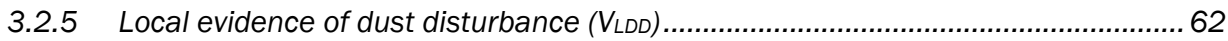

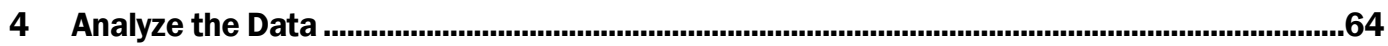

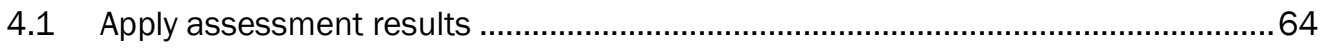

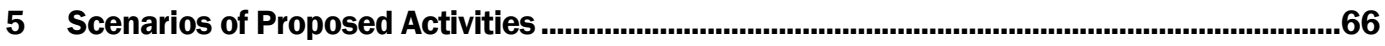

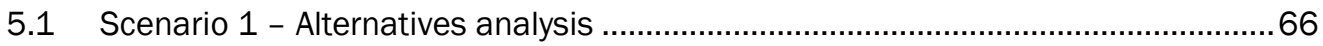

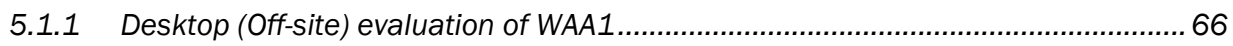

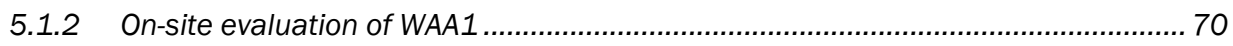

5.1.3 Desktop (Off-site evaluation) of WAA2 ................................................................... 74

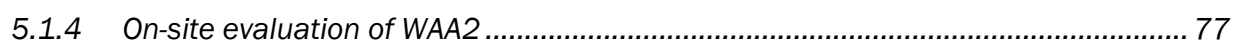

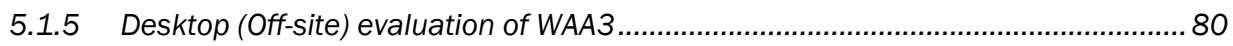

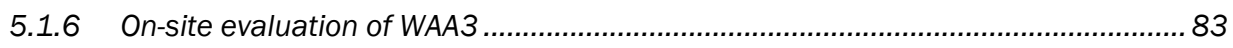

5.1.7 Alternatives analysis for WAA1, WAA2, and WAA3 .............................................. 85

5.2 Scenario 2 - Assessment of linear project areas................................................. 87

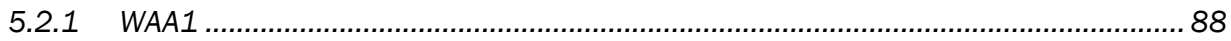

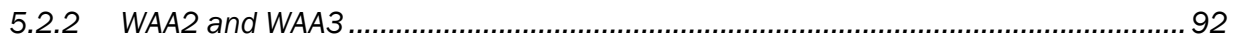

5.3 Scenario 3 - Assessment of preservation-only mitigation......................................95

5.3.1 WAA1 and WAA2 pre-project assessment (WAA1 PRE and WAA2PRE) .........................96

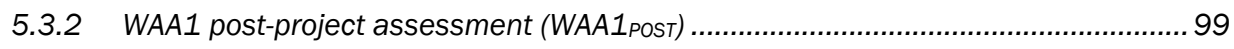

5.3.2 WAA2 post-project assessment (WAA2POST) ..................................................... 102

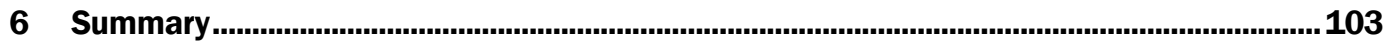

References ..................................................................................................................................... 104

Appendix A: Resources for Wetland Classification, Assisting in Site Characterization, and Conducting Off-Site Analysis of Wetlands within the North Slope Region................... 109

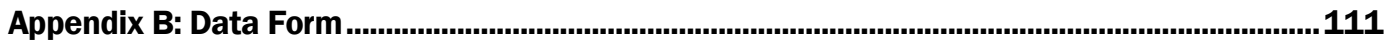

\section{Report Documentation Page}




\section{Figures and Tables}

\section{Figures}

Figure 1. Arctic Foothills (AF) and Arctic Coastal Plain (ACP) North Slope Region of Alaska. The region north of the Brooks Range comprises the reference domain addressed by this rapid wetland assessment method. Reference data were collected at 88 sample locations (not all data collection locations are visible due to map scale).

Figure 2. Reference domain of the North Slope region as defined by Ecoregion and MLRA.............. 2

Figure 3. Example of the flats wetland class occurring on ice wedge polygons along the ACP near Utqiagvik (formally known as Barrow), AK. The low-lying linear features are underlain by ice wedges; and the regions in between, which are also permafrost, are composed of organic soil horizons with subsurface horizons that consist of frozen gravels, sands, and silts with an ice-rich matrix. Photo by Thomas Douglas.

Figure 4. Flats wetlands occur throughout the Arctic Foothills, often located in large valleys and basins. Note the presence of microtopography in the image foreground.

Figure 5. A riverine wetland located in the ACP region.

Figure 6. Overbank flooding from the Sagavanirktok River breached the Dalton highway during a spring flood event in 2015 (Photo by Loren Holmes, Alaska Dispatch News, May 24, 2015).

Figure 7. Depression wetlands located in the AF (top) and ACP (bottom) ........................................... 9

Figure 8. Lacustrine fringe dominated by Arctophila fulva (top) and tidal fringe wetlands containing Puccinellia spp. (bottom).

Figure 9. Slope wetland located within the AF region. ....................................................................12

Figure 10. North Slope Land Cover types (NSSI 2013). .................................................................17

Figure 11. A gray wolf (Canis lupus) traversing a depression wetland habitat within the AF.............19

Figure 12. A tundra swan (Cygnus columbianus) feeding adjacent to a lacustrine fringe wetland of the ACP.

Figure 13. Caribou (Rangifer tarandus) moving across a tidal fringe wetland near the Beaufort Sea within the ACP.

Figure 14. An Arctic Fox (Vulpes lagopus) outside its den site adjacent to a lacustrine fringe wetland within the ACP.

Figure 15. Muskoxen (Ovibos moschatus) in a flats wetland adjacent to the Dalton Highway within the ACP..

Figure 16. A brown bear (Ursus arctos) drinking from a pool adjacent to a riverine wetland near the Dalton Highway within the AF Region.

Figure 17. A Ptarmigan (Lagopus sp.) hiding within a slope wetland within the AF.

Figure 18. Off-site variable collection occurs at two spatial scales, with five variables (VLL, $\mathrm{V}_{\mathrm{IH}}, \mathrm{V}_{\mathrm{DD}}, \mathrm{V}_{\mathrm{TK}}$, and $\mathrm{V}_{\mathrm{SW}}$ ) examined within an $80 \mathrm{~m}$ radius circle and three variables (VLD, $\mathrm{V}_{\mathrm{IW}}$, and $V_{D R}$ ) examined within a larger $800 \mathrm{~m}$ radius area that encompasses the $80 \mathrm{~m}$ radius circle. Please note that the $80 \mathrm{~m}$ radius plot is dead center of the $800 \mathrm{~m}$ radius plot.

Figure 19. Plot layout for on-site data collection. Thirty meter transects are positioned perpendicularly for the measurement of $\mathrm{V}_{\text {Мт. }}$. A single $1 \mathrm{~m}$ quadrat should be located in a representative area within each quarter section for the measurement of $\mathrm{V}_{\mathrm{SR}}$ and $\mathrm{V}_{\mathrm{BG}}$. 
Observations of local evidence of both dust deposition ( $\left.\mathrm{V}_{\mathrm{LDD}}\right)$ and thermokarst $\left(\mathrm{V}_{\mathrm{LTK}}\right)$ are made throughout the sample area.

Figure 20. Example of a proposed mitigation project area that contains three WAAs $(A=$ flats; $B=$ depression; $C=$ riverine) that represent three undisturbed HGM classes that must each be analyzed separately.

Figure 21. Example of a proposed mitigation project area containing one HGM wetland class. A portion of the wetland is undisturbed and other portions show different levels of disturbance. Note that separate wetland assessment areas are necessary in (A) the portion lacking any sign of disturbance in a flats wetland; this area will be preserved, (B) areas containing some disturbance in a flats wetland as a result of the road and fill pad; this area would undergo rehabilitation, and (C) areas filled by the road and fill pad; this area would undergo re-establishment.

Figure 22. The dashed white line identifies the project area. There are two wetland classes present. One wetland class has both disturbed and undisturbed areas. Therefore, three wetland assessment areas are defined. A representative data point is selected for each wetland assessment area: (A) WAA 1, a disturbed flats wetland affected by infrastructure development (i.e., pad and existing road), (B) WAA 2, a riverine wetland, and (C) WAA 3, an undisturbed flats wetland.

Figure 23. Percent $V_{L L D}$ assessed at the $80 \mathrm{~m}$ radius. The blue highlighted area contains a primary road, secondary road, and gravel fill pad, which occupy $23 \%$ of the plot. As a result, the total disturbed area equals $23 \%$, corresponding to a variable subindex score of 0.43 for VLLD. The portion highlighted in transparent orange represents an area where dust was deposited adjacent to the roadway (see discussion of $V_{D D}$ below).

Figure 24. Association between the percentage of the $80 \mathrm{~m}$ radius plot that shows disturbance and the VLLD subindex score.

Figure 25. Percent $V_{s w}$ assessed at the $80 \mathrm{~m}$ scale, shown in transparent blue. Site $A$ exhibits anthropogenically derived open water adjacent to the road and pipeline; Site B contains open water associated with a large borrow site.

Figure 26. Ground view of $V_{s w}$ adjacent to heavily disturbed area. Placement of fill material disrupted drainage, which led to an increase in surface water..

Figure 27. Association between the percentage of the $80 \mathrm{~m}$ radius area occupied by $\mathrm{V}_{\mathrm{sw}}$ value and the $\mathrm{V}_{\mathrm{sw}}$ variable subindex score.

Figure 28. $V_{\mathbb{H}}$ assessed at the $80 \mathrm{~m}$ scale. The shaded segment, is impeded by the roadway passing through the plot.

Figure 29. Association between the number of quarter segments within the $80 \mathrm{~m}$ radius area that contain an impediment to hydrology value and the $\mathrm{V}_{\mathbb{H}}$ variable subindex score.

Figure 30. Evidence of dust deposition adjacent to roadways. Since this variable is assessed as presence or absence, it is not necessary to calculate the area where evidence of dust deposition occurs.

Figure 31. Example of thermokarst features located adjacent to infrastructure; note the patterns of deformed polygonal ground occurring at the edge of fill pads and roads.

Figure 32. $V_{L D}$ assessed at the $800 \mathrm{~m}$ scale, shown in transparent blue.

Figure 33. Association between the percentage of the $800 \mathrm{~m}$ radius area occupied by disturbance and the $V_{L D}$ variable subindex score.

Figure 34. $V_{I w}$ assessed at the $800 \mathrm{~m}$ scale. The shaded segments, $C$ and $D$, are impeded by aboveground utilities and associated structures.

Figure 35. Association between the number of quarter segments within the $800 \mathrm{~m}$ radius area that contain an impediment to wildlife value and the VIw variable subindex score. 
Figure 36. $V_{D R}$ from the assessment site in meters, at the $800 \mathrm{~m}$ scale.

Figure 37. Association between the distance to roadway value and the $V_{D R}$ variable subindex score.

Figure 38. Layout for on-site data collection includes the location of transects $\left(\mathrm{V}_{\mathrm{MT}}\right)$ and quadrats $\left(\mathrm{V}_{\mathrm{BG}}, \mathrm{V}_{\mathrm{SR}}\right)$. Note that $\mathrm{V}_{\mathrm{LDD}}$ and $\mathrm{V}_{\mathrm{LTK}}$ should be documented anywhere within the sample area.

Figure 39. A transect line setup with a level, suspended line for sampling (A), and a closeup of a rod setup for a transect line end (B).

Figure 40. Measuring the distance from the reference level (i.e., level string-line) to the ground surface at each $1 \mathrm{~m}$ interval along the transect.

Figure 41. Partial transect line showing elevation difference measurements as measured along $1 \mathrm{~m}$ intervals.

Figure 42. Association between the microtopography value and the $\mathrm{V}_{\mathrm{MT}}$ variable subindex score for fringe and depression wetland classes.

Figure 43. Association between the microtopography value and the $\mathrm{V}_{\mathrm{MT}}$ variable subindex score for riverine and flats wetland classes.

Figure 44. Association between the microtopography value and the $\mathrm{V}_{\mathrm{MT}}$ variable subindex score for slope wetlands.

Figure 45. Association between the average species richness observed in four $1 \mathrm{~m}^{2}$ quadrats and the $\mathrm{V}_{\mathrm{SR}}$ variable subindex score within the ACP region.

Figure 46. Association between the average species richness observed in four $1 \mathrm{~m}^{2}$ quadrats and the $V_{S R}$ variable subindex score within the foothills region.

Figure 47. Examples of quadrat with bare ground estimates of $(A) 100 \%,(B) 90 \%,(C)$ $25 \%$, and (D) $0 \%$.

Figure 48. Association between the average percentage of bare ground observed within four $1 \mathrm{~m}^{2}$ quadrats and the $\mathrm{V}_{\mathrm{BG}}$ variable subindex score.

Figure 49. Examples of thermokarst occurring in an area where vegetation has been removed (top), and the area adjacent to infrastructure that has formed thermokarst features (bottom).

Figure 50. Examples of dust accumulation on vegetation.

Figure 51. Proposed alternative pads with access roads, and pad expansion. ...............................67

Figure 52. Proposed activities with designated WAAs. .......................................................................67

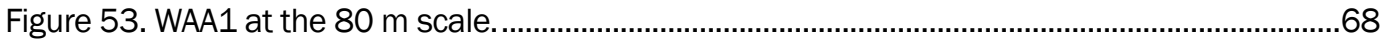

Figure 54. WAA1 at the $800 \mathrm{~m}$ scale. A linear discolored area crossing the northern portion of the plot indicates a prior disturbance. This disturbance is less than $1 \%$ of the area and, therefore, received a VLD subindex score of 0 .

Figure 55. Example of completed off-site assessment for WAA1 using the wetland assessment calculator.

Figure 56. Demonstrative photos for a site assessment of WAA1 situated within the ACP region.

Figure 57. Example of wetland assessment calculator for WAA1 on-site variables..........................72

Figure 58. Example of summary of assessment scores for WAA1 generated using the wetland assessment calculator. .

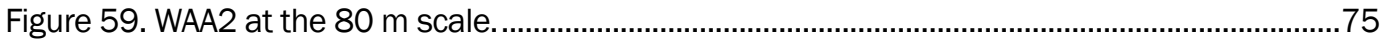

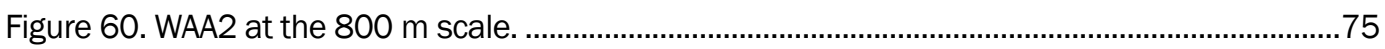


Figure 61. Example of off-site assessment scores for WAA2

Figure 62. On-site photos for WAA2 situated within the ACP, note the dominance of Arctophila fulva, which results in a species richness variable subindex score of 1.0.

Figure 63. Example of on-site data for WAA2, which was determined by using the wetland assessment calculator.

Figure 64. Example of summary of assessment scores for WAA2, which was generated using the wetland assessment calculator.

Figure 65. WAA3 at the $80 \mathrm{~m}$ scale.

Figure 66. WAA3 at the $800 \mathrm{~m}$ scale. Shaded portion of the plot is impeded to wildlife movement.

Figure 67. Example of wetland assessment calculator used to determine off-site scores for WAA3.

Figure 68. Demonstrative photos for on-site assessment of WAA3 situated within the ACP and directly adjacent to a gravel pad.

Figure 69. Example of on-site wetland assessment scores, which were determined by using the wetland assessment calculator.

Figure 70. Summary of wetland assessment scores generated for WAA3 using the wetland assessment calculator.

Figure 71. Wetland assessment component scores for WAA1, WAA2, and WAA3.

Figure 72. Proposed well-pad and access road.

Figure 73. Project area with three WAAs identified.

Figure 74. WAA1 located adjacent to an existing well-pad. The green shaded $1 / 4$ segment of the $80 \mathrm{~m}$ radius area has impediments to hydrology. The gray shaded portion of the $800 \mathrm{~m}$ radius area has impediments to wildlife.

Figure 75. Example of Desktop (off-site) assessment scores for WAA1 using the wetland assessment calculator. ..................................................................................................................91

Figure 76. WAA2 located in a riverine wetland, and WAA3 located in a flats wetland. 93

Figure 77. Example of summary of assessment scores for WAA2 generated using the wetland assessment calculator. Though it is located in a different HGM class, WAA3 would receive the same scores as WAA2.

Figure 78. Parcel boundary and projected footprint of well-pad and access road, as identified in mitigation plan. .96

Figure 79. Location of WAA1 and WAA2 with associated data points.

Figure 80. Example of off-site assessment scores for WAA1PRE using the wetland assessment calculator.

Figure 81. Example of summary of assessment scores for WAA1Post generated using the wetland assessment calculator.

\section{Tables}

Table 1. Comparison chart of wetland classification schemes available for use on the North Slope region of Alaska.

Table 2. Summary of wetland assessment scores for WAA1 ............................................................73

Table 3. Wetland assessment component scores for WAA1, WAA2, and WAA3...............................86 


\section{Preface}

Development of this guidebook was conducted for the Wetlands Regulatory Assistance Program under Project, A1210-North Slope Alaska. The program manager was Ms. Sally Stroupe.

The report was prepared by the Ecosystem Evaluation and Engineering Division, Wetlands and Coastal Ecology Branch, U.S. Army Engineer Research and Development Center, Environmental Laboratory (ERDCEL). At the time of publication, Ms. Patty Tolley was Chief, CEERD-EE-W; Dr. Mark D. Farr was Chief, CEERD-EE; and Dr. Al Cofrancesco, CEERDEM-W was the Technical Director for ERDC-EL Civil Works. The Deputy Director of ERDC-EL was Dr. Jack Davis, and the Director was Dr. Beth Fleming.

Additional preparation was provided by Mr. Calvin Alvarez, Mr. Jeremy Grauf, and Ms. Sheila Newman of the USACE, Alaska District.

COL Bryan S. Green was Commander of ERDC, and Dr. David W. Pittman was the Director.

The following people made major contributions to the development of this guidebook, including field data collection and participation in peer review: Estrella Campellone, USACE Alaska District; Gayle Martin, U.S. Environmental Protection Agency (USEPA); Louise Smith, U.S. Fish and Wildlife Service (USFWS); and Bill Streever, British Petroleum (BP) (retired). Unless otherwise indicated, all photograph credits are attributed to Dr. Nathan R. Beane.

The following provided additional technical review and comments:

Dr. Tosin Sekoni, Steve Currie, and Sally Stroupe, ERDC-EL; Mary Anne Thiesing, USEPA; David V. D’Amore, U.S. Forest Service (USFS); Dr. Thomas Roberts, Tennessee Technological University; Michelle Schuman, U.S. Department of Agriculture - Natural Resources Conservation Service (USDA-NRCS); Richard Darden, USACE Alaska District; and representatives from USACE Headquarters. Questions regarding the application of this guidebook should be directed to the 
USACE Alaska District - Regulatory Division at 907-753-2712;

regpagemaster@usace.army.mil.

This report should be cited as:

Berkowitz, J. F., N. R. Beane, K. Philley, and M. W. Ferguson. 2017. Operational draft regional guidebook for the rapid assessment of wetlands in the North Slope region of Alaska. ERDC/EL TR-17-14. Vicksburg, MS: U.S. Army Engineer Research and Development Center. 


\section{Acronyms}

\begin{tabular}{|c|c|}
\hline $\mathrm{ACP}$ & Arctic Coastal Plain \\
\hline ADFG & Alaska Department of Fish and Game \\
\hline $\mathrm{AF}$ & Arctic Foothills \\
\hline AGDC & Alaska Geospatial Data Clearinghouse \\
\hline AVHRR & Advanced Very High Resolution Radiometer \\
\hline BP & British Petroleum \\
\hline CDM & Credit Debit Methodology \\
\hline DEMs & Digital Elevation Models \\
\hline ERDC-EL & $\begin{array}{l}\text { U.S. Army Engineer Research and Development Center, } \\
\text { Environmental Laboratory }\end{array}$ \\
\hline GINA & Geographic Information Network of Alaska \\
\hline GIS & Geographic Information System \\
\hline HGM & Hydrogeomorphic \\
\hline MLRAs & Major Land Resource Areas \\
\hline NSSI & North Slope Science Initiative \\
\hline USDA-NRCS & $\begin{array}{l}\text { U.S. Department of Agriculture - Natural Resources } \\
\text { Conservation Service }\end{array}$ \\
\hline USDOI-BLM & $\begin{array}{l}\text { U.S. Department of the Interior - Bureau of Land } \\
\text { Management }\end{array}$ \\
\hline USEPA & U.S. Environmental Protection Agency \\
\hline USFS & U.S. Forest Service \\
\hline USFWS & U.S. Fish and Wildlife Service \\
\hline USGS & United States Geological Survey \\
\hline $\mathrm{V}_{\mathrm{BG}}$ & Bare ground \\
\hline
\end{tabular}




$\begin{array}{ll}V_{\text {DD }} & \text { Evidence of dust deposition } \\ V_{\text {DR }} & \text { Distance to roadway } \\ V_{\text {IH }} & \text { Impediment to hydrology } \\ V_{\text {IW }} & \text { Impediment to wildlife } \\ V_{\text {LD }} & \text { Landscape disturbance } \\ V_{\text {LDD }} & \text { Local evidence of dust disturbance } \\ V_{\text {LLD }} & \text { Local landscape disturbance } \\ V_{\text {LTK }} & \text { Local evidence of thermokarst } \\ V_{\text {MT }} & \text { Microtopography } \\ \text { VSR } & \text { Species richness } \\ \text { VSW } & \text { Anthropogenically derived surface water } \\ V_{\text {TK }} & \text { Evidence of thermokarst } \\ \text { WAA } & \text { Wetland Assessment Area } \\ \text { WAA1POST } & \text { WAA1 post-project assessment } \\ \text { WAA2POST } & \text { WAA2 post-project assessment } \\ \text { WAA1PRE } & \text { WAA1 pre-project assessment } \\ \text { WAA2PRE } & \text { WAA2 pre-project assessment }\end{array}$




\section{Characterization of Regional Wetland Subclasses for North Slope Alaska}

\subsection{Introduction}

This guidebook was developed for the purpose of rapidly assessing wetlands within the North Slope region of Alaska (Figures 1 and 2). The method is designed to support permit review. This method does not identify the importance of wetlands within a watershed, measure specific wetland functions, or determine sufficiency for mitigation on its own. This methodology can be used to inform project alternatives, assess unavoidable impacts, and aid in the determination of sufficiency for mitigation.

This guidebook begins with a description of the North Slope, including summary information regarding the spatial extent of the area, climate, topography, soils, vegetation, fauna, and hydrology of the region.

Additionally, a description of the wetland classes occurring within the region is provided.

Figure 1. Arctic Foothills (AF) and Arctic Coastal Plain (ACP) North Slope Region of Alaska. The region north of the Brooks Range comprises the reference domain addressed by this rapid wetland assessment method. Reference data were collected at 88 sample locations (not all data collection locations are visible due to map scale).

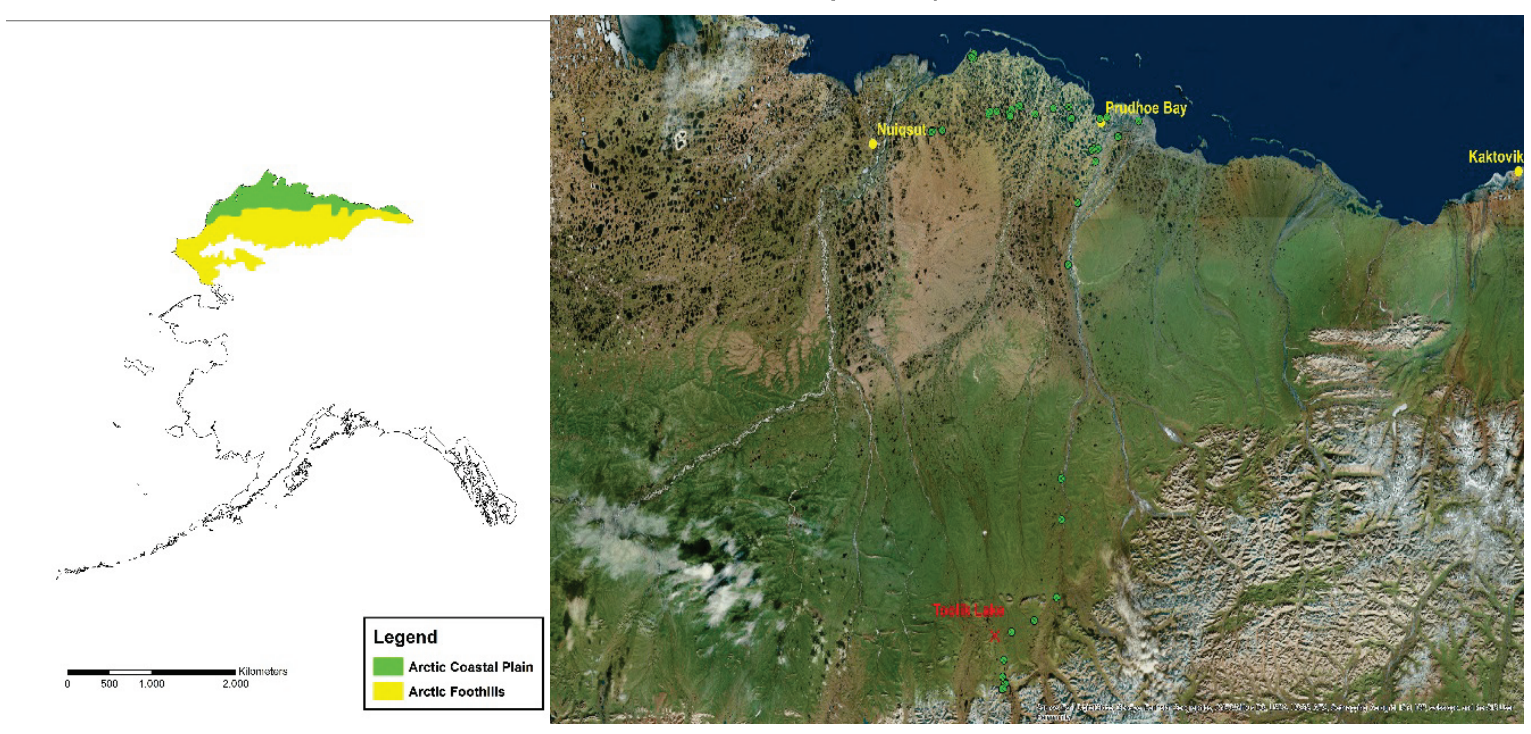


Figure 2. Reference domain of the North Slope region as defined by Ecoregion and MLRA.

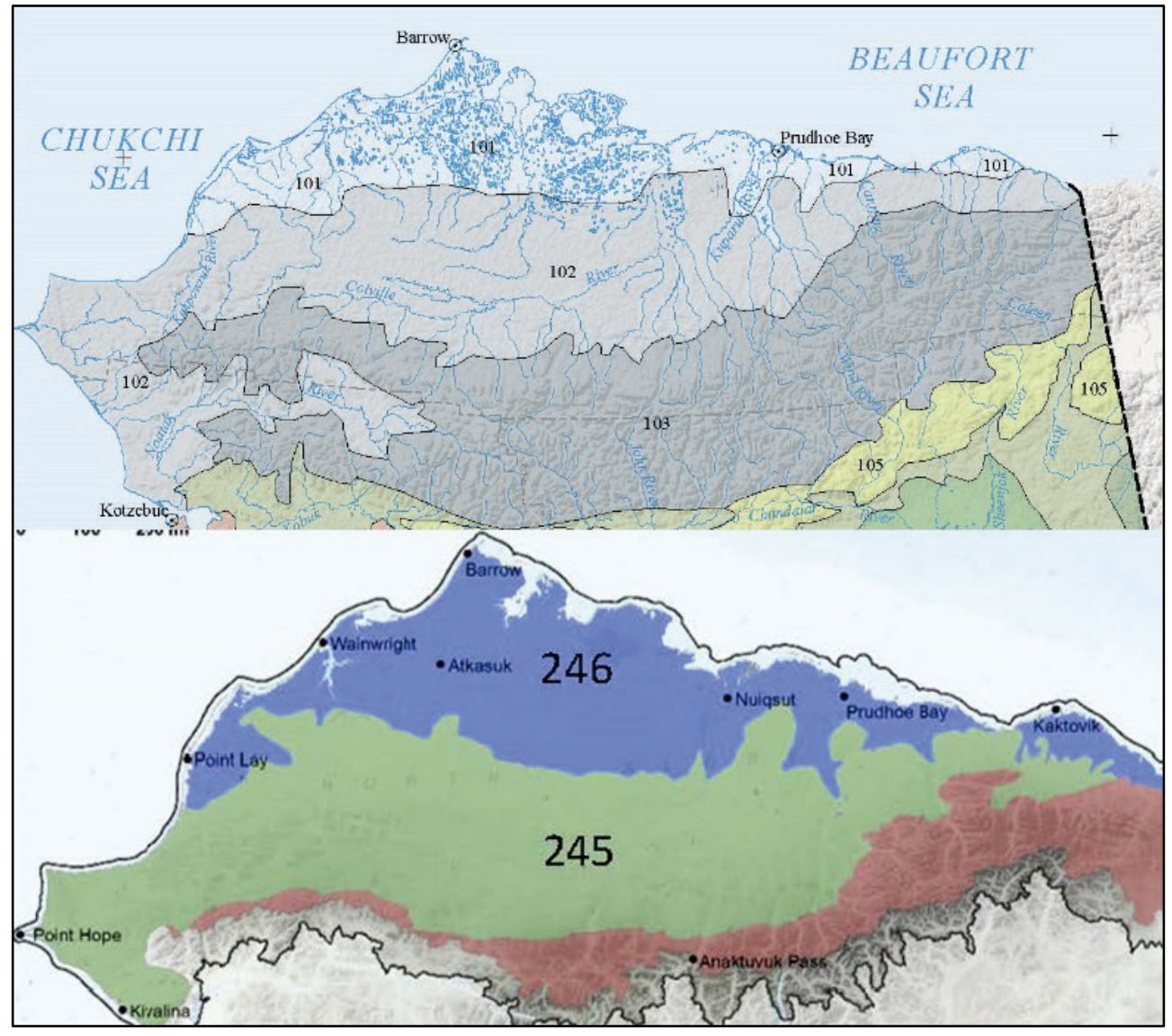

The development of the assessment guidebook followed the guidance provided by Smith et al. (2013) for wetland assessments including: (1) ecosystem classification, (2) assessment variable and equation calibration based upon reference data, (3) a written protocol for data collection, (4) peer review, and (5) verification of results. This guidebook was developed and underwent peer review with the input of a multi-agency, interdisciplinary development team including wetland scientists from USACE, USEPA, USFWS, USDA-NRCS, academia, and experts from the private sector. Background information about wetland classification and rapid wetland assessment development procedures can be found in the following documents:

- A hydrogeomorphic classification for wetlands (Brinson 1993). https://wetlands.el.erdc.dren.mil/literature.html

- Hydrogeomorphic (HGM) Approach to assessing wetland functions: Guidelines for developing guidebooks (Version 2) (Smith et al. 2013). https://wetlands.el.erdc.dren.mil/procedure.html 
The assessment equations utilized within this guidebook were calibrated using data from reference wetlands within the region including areas located near the Toolik Lake Long-Term Ecological Research Station, Prudhoe Bay, Kuparuk, Oliktok Point, Milne Point, the Miluveach River, and along the Dalton highway (Figure 1). The methodology is applicable throughout the North Slope region as defined within. The assessment equations may be refined on a regional or sub-regional basis to account for observed differences in select variables based upon the availability of additional data (Smith et al. 2013). For example, additional reference data may be collected and used to recalibrate assessment equations (Summers et al. 2017).

\subsection{Reference domain}

The reference domain (i.e., area of application) for this guidebook is collectively referred to as the North Slope. The reference domain extends northward from the Brooks Range, encompassing the AF and the ACP Major Land Resource Areas (MLRAs), which approximately correspond to Ecoregions 101 and 102 (Figure 2; Bailey 1995). The reference domain includes expansive landscapes, encompassing nearly 170,000 square kilometers (USDA NRCS 2004; 2006). These regions are comprised of many braided rivers, thousands of lakes, and numerous wetland habitats.

\subsection{Wetland classification}

Several wetland classification schemes have been applied to wetlands, including areas in the North Slope region. The most common classifications include the HGM approach outlined in Smith et al. (1995) and Brinson (1993), which utilized hydrology source, flow regime, and landscape position, the USFWS classification system (Cowardin et al. 1979), which is based upon water source and vegetative cover, and the North Slope Science Initiative (NSSI 2013), which produced a land cover classification map. Others, including Jorgenson et al. (2009) and Viereck et al. (1992), determined wetland classification based upon a variety of characteristics including vegetation type and growth form, landform, and hydrologic regime (e.g., wet sedge meadow). Table 1 provides a comparison chart for the major wetland classification schemes available for use in the region. Appendix A provides a list of resources that can aid in the determination of wetland classification within the region. 
Table 1. Comparison chart of wetland classification schemes available for use on the North Slope region of Alaska. ${ }^{1}$

\begin{tabular}{|l|l|l|l|}
\hline HGM class & Cowardin & $\begin{array}{l}\text { North Slope Science } \\
\text { Initiative }\end{array}$ & Jorgenson et al. (2009) \\
\hline Flats & PEM, PSS & $\begin{array}{l}\text { Wet sedge, Mesic } \\
\text { sedge-dwarf shrub } \\
\text { tundra, tussock } \\
\text { tundra, low-tall willow, } \\
\text { dwarf shrub, sparsely } \\
\text { vegetated }\end{array}$ & $\begin{array}{l}\text { Low/high centered polygon, } \\
\text { moist/wet sedge meadow }\end{array}$ \\
\hline Riverine & PEM, PSS & $\begin{array}{l}\text { Wet sedge, tussock } \\
\text { tundra, low-tall willow }\end{array}$ & $\begin{array}{l}\text { Wet sedge meadow, gravel/vegetated } \\
\text { bars }\end{array}$ \\
\hline Depression & PEM, PEMC & $\begin{array}{l}\text { Low-tall willow, wet } \\
\text { sedge }\end{array}$ & $\begin{array}{l}\text { Low centered polygon, moist/wet } \\
\text { sedge meadow, drained lake basins }\end{array}$ \\
\hline Lacustrine Fringe & PEM, PEMH & $\begin{array}{l}\text { Wet sedge, Mesic } \\
\text { sedge-dwarf shrub } \\
\text { tundra, sparsely } \\
\text { vegetated }\end{array}$ & $\begin{array}{l}\text { Moist/wet sedge meadow, low/high } \\
\text { centered polygon }\end{array}$ \\
\hline Tidal Fringe & EEM & $\begin{array}{l}\text { Wet sedge, wet grass } \\
\text { (Puccinellia } \\
\text { phryganodes) }\end{array}$ & $\begin{array}{l}\text { Tidal flat, low/high centered polygon, } \\
\text { lacustrine fringe (Arctophila fluva) }\end{array}$ \\
\hline Slope & PEM, PSS & $\begin{array}{l}\text { Tussock tundra, } \\
\text { tussock shrub tundra, } \\
\text { birch ericaceous low } \\
\text { shrub }\end{array}$ & Moist/wet sedge meadow \\
\hline
\end{tabular}

The rapid wetland assessment described herein utilizes the HGM wetland classification approach. Wetland classifications based upon other schemes should be translated into HGM classes contingent upon analysis of available data (e.g., aerial images, GIS layers, on-site observations) in conjunction with Table 1. The HGM classification scheme is selected because: (1) HGM addresses all of the wetland types occurring in the North Slope region, and (2) each of the wetlands observed during assessment development can be described using a single HGM class, whereas a subset of the wetlands examined were characterized by multiple classes using other classification schemes. Each regional wetland class is briefly described below.

\footnotetext{
1 Explanation of codes available in Cowardin et al. (1979) Jorgenson et al. (2009). The rapid wetland assessment does not cover streams or open waters (e.g., lakes, ponds)
} 


\subsubsection{Flats}

The flats wetland class occurs on low gradient areas throughout the North Slope and represents one of the most common wetland types found throughout the region. Most of the flats in the region are characterized by organic surface soil horizons underlain by permafrost consisting of organic and mineral soil materials, often containing gravels. Flats may exhibit microtopographic relief, including the formation of polygonal ground resulting from repeated cycles of freeze-thaw events (Davis 2001). Additionally, many flats wetlands in the region are characterized by areas of low- and high-centered polygons on polygonal ground (Figures 3 and 4). Hydrologic sources supporting flats include direct precipitation, snowmelt, and seasonal thaw of the surface-active layer.

Figure 3. Example of the flats wetland class occurring on ice wedge polygons along the ACP near Utqiagvik (formally known as Barrow), AK. The low-lying linear features are underlain by ice wedges; and the regions in between, which are also permafrost, are composed of organic soil horizons with subsurface horizons that consist of frozen gravels, sands, and silts with an ice-rich matrix. Photo by Thomas Douglas. 
Figure 4. Flats wetlands occur throughout the Arctic Foothills, often located in large valleys and basins. Note the presence of microtopography in the image foreground.

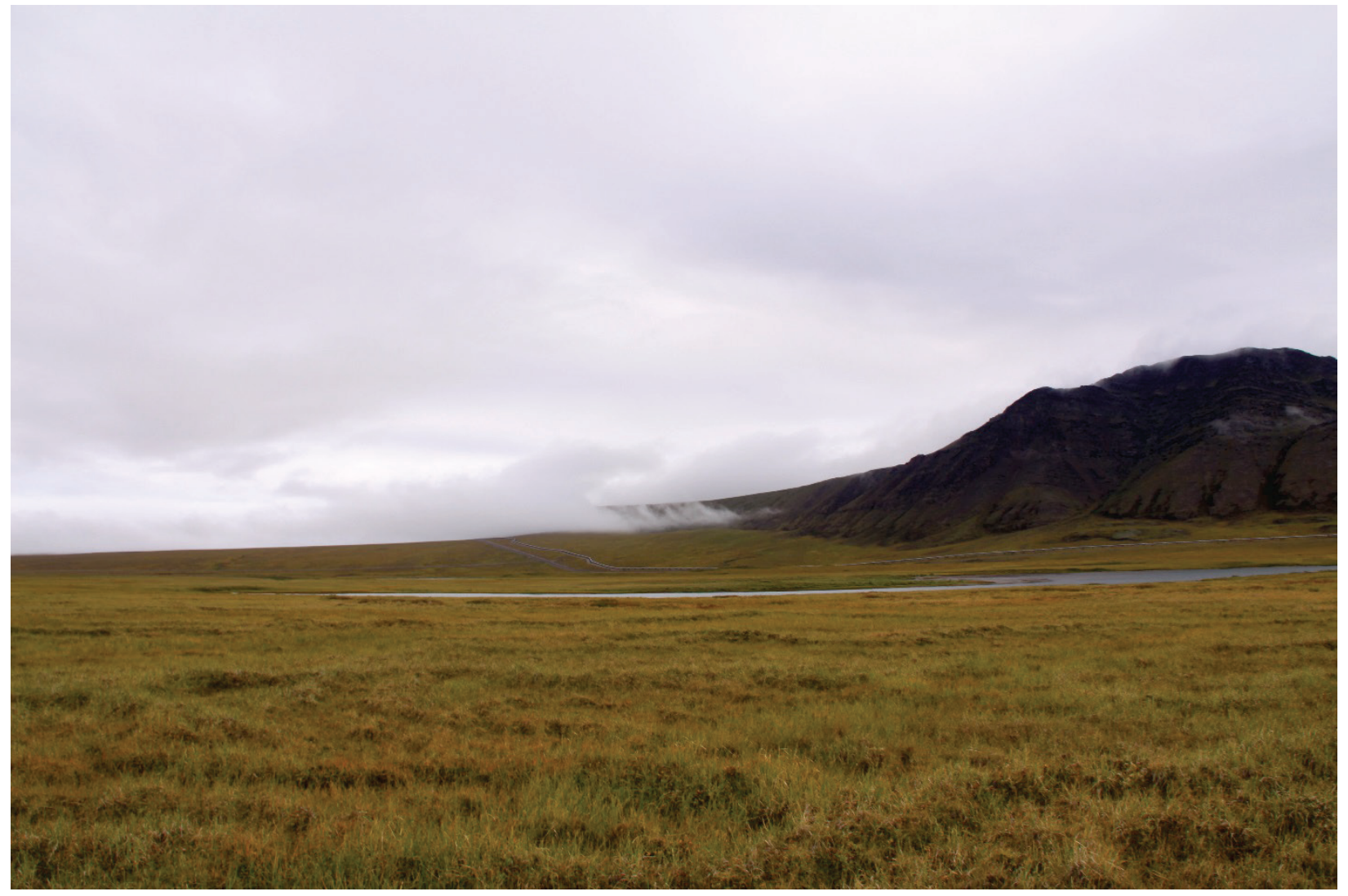

\subsubsection{Riverine}

The riverine class includes those wetlands that are subject to overbank flooding from streams and rivers (Figures 5 and 6) (Brinson 1993; Noble and Berkowitz 2016). Potential hydrologic sources include both overbank and backwater flooding, with most flooding associated with early summer meltwater runoff. A typical backwater flooding scenario occurs when a large stream that is in flood stage prevents the tributary network from draining efficiently, and the low-lying areas associated with those tributaries fill with water. Alternatively, ice dams, high tides, or prevailing ocean winds can prevent efficient drainage of freshwater rivers, thus leading to backwater flooding on the adjacent coastal plain. Riverine wetlands occur primarily along banks, on small gravel and/or vegetated bars within the channels of streams, and on the limited floodplain surfaces adjacent to some channels. Off-channel areas that are subject to overbank flows may be similar to flats wetlands. Riverine wetlands include palustrine wetlands found in the active flood plain. 
Figure 5. A riverine wetland located in the ACP region.

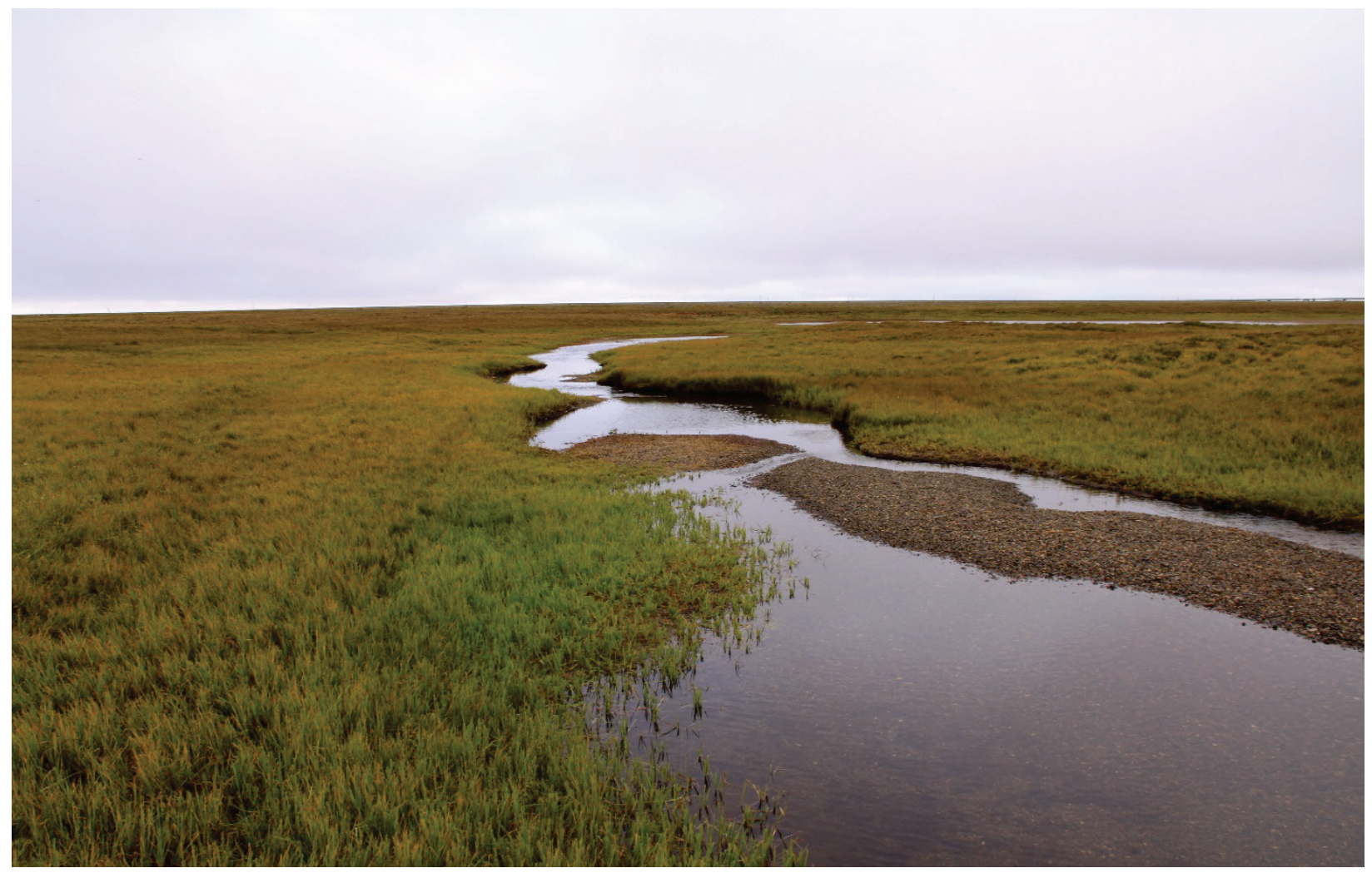

Figure 6. Overbank flooding from the Sagavanirktok River breached the Dalton highway during a spring flood event in 2015 (Photo by Loren Holmes, Alaska Dispatch News, May 24, 2015).

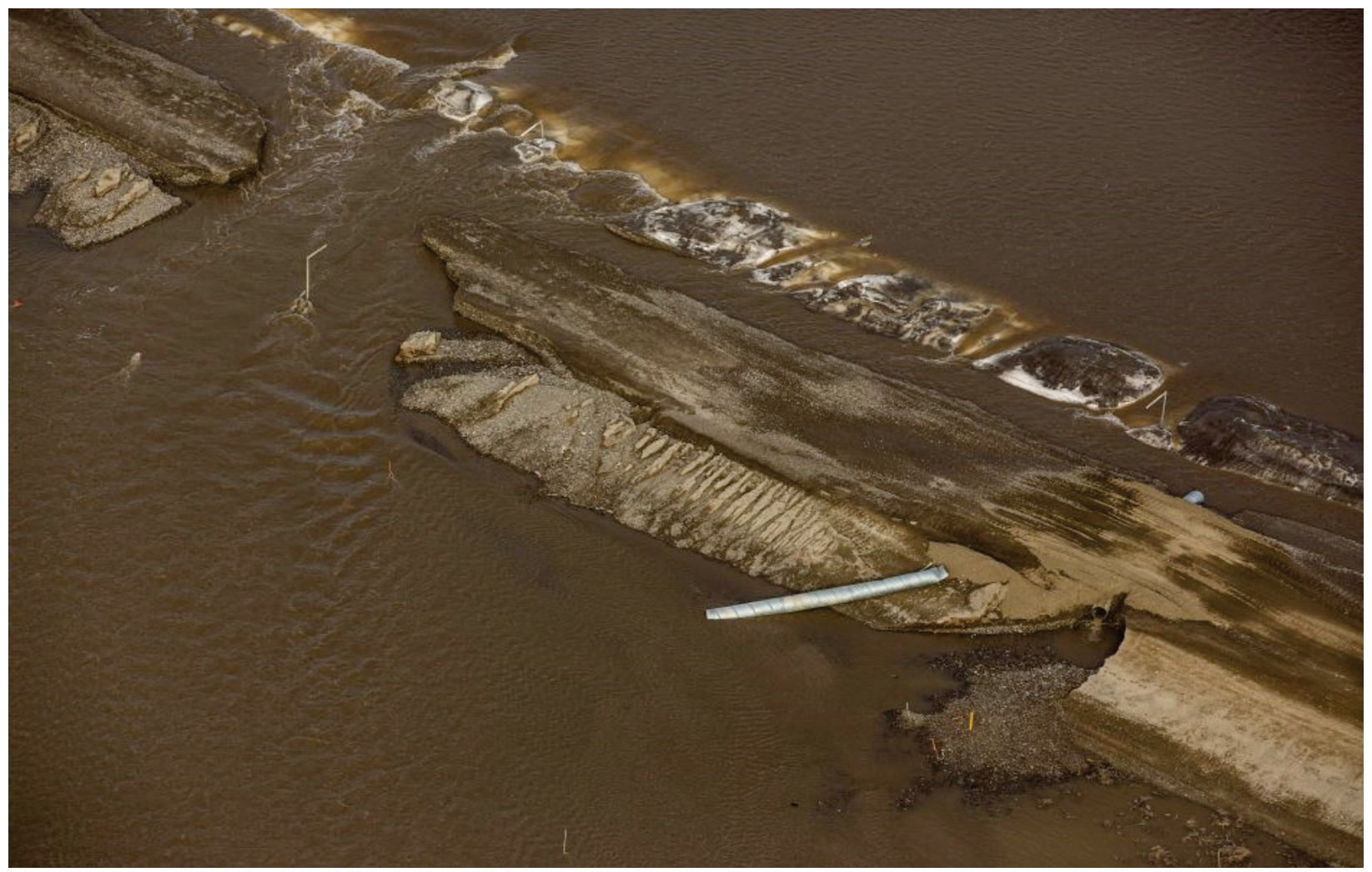




\subsubsection{Depressions}

Depression wetlands occur in abandoned channels, large point bar swales, drained lake basins, and other low-lying areas within the landscape (Figure 7) (Brinson 1993; Noble and Berkowitz 2016). Depression wetlands hold water for extended periods of time due to their size, depth, and ability to collect surface and subsurface flows from an area much larger than the depression itself. They tend to fill following early summer thaw and snowmelt, which is prior to the onset of higher evaporation rates.

\subsubsection{Fringe (e.g., lacustrine, tidal, and vegetated shallows)}

Fringe wetlands occur along the perimeter of water bodies that maintain an open water zone year round (Figure 8). Fringe wetlands occur in the fluctuation zone of the water body, which supplies the major source of hydrology. Fringes can be differentiated from depression wetlands by the fact that in fringe wetlands, the dominant hydrologic source is overbank flow from lakes or tidal fluctuations in which hydrodynamics remain bidirectional. Conversely, depression wetland hydrodynamics are dominated by vertical hydrodynamics with hydrologic sources including return flow from surrounding surface and/or groundwaters and interflow. A large number of fringe wetlands occur along the shores of freshwater lakes and along the shoreline of the Beaufort and Chukchi Seas within the North Slope region. Although freshwater and tidal fringe wetlands exhibit different hydrologic sources and hydrodynamics, they share several similarities including low degree of topographic relief, low species richness compared to other HGM wetland classes, and consistently saturated or inundated soil conditions. As a result, for the purposes of this wetland assessment, fringe wetlands include both freshwater lacustrine and tidal fringe areas.

Tidal fringe wetlands occur along coasts and estuaries and are under the influence of the Beaufort Sea tides (approximately $0.3 \mathrm{~m}$ ) or Arctic Ocean. These wetlands intergrade landward with riverine wetlands where tidal current diminishes and riverflow becomes the dominant water source. Additional water sources may be groundwater discharge and precipitation. These fringe wetlands are dominated by Puccinellia phryganodes. 
Figure 7. Depression wetlands located in the AF (top) and ACP (bottom).

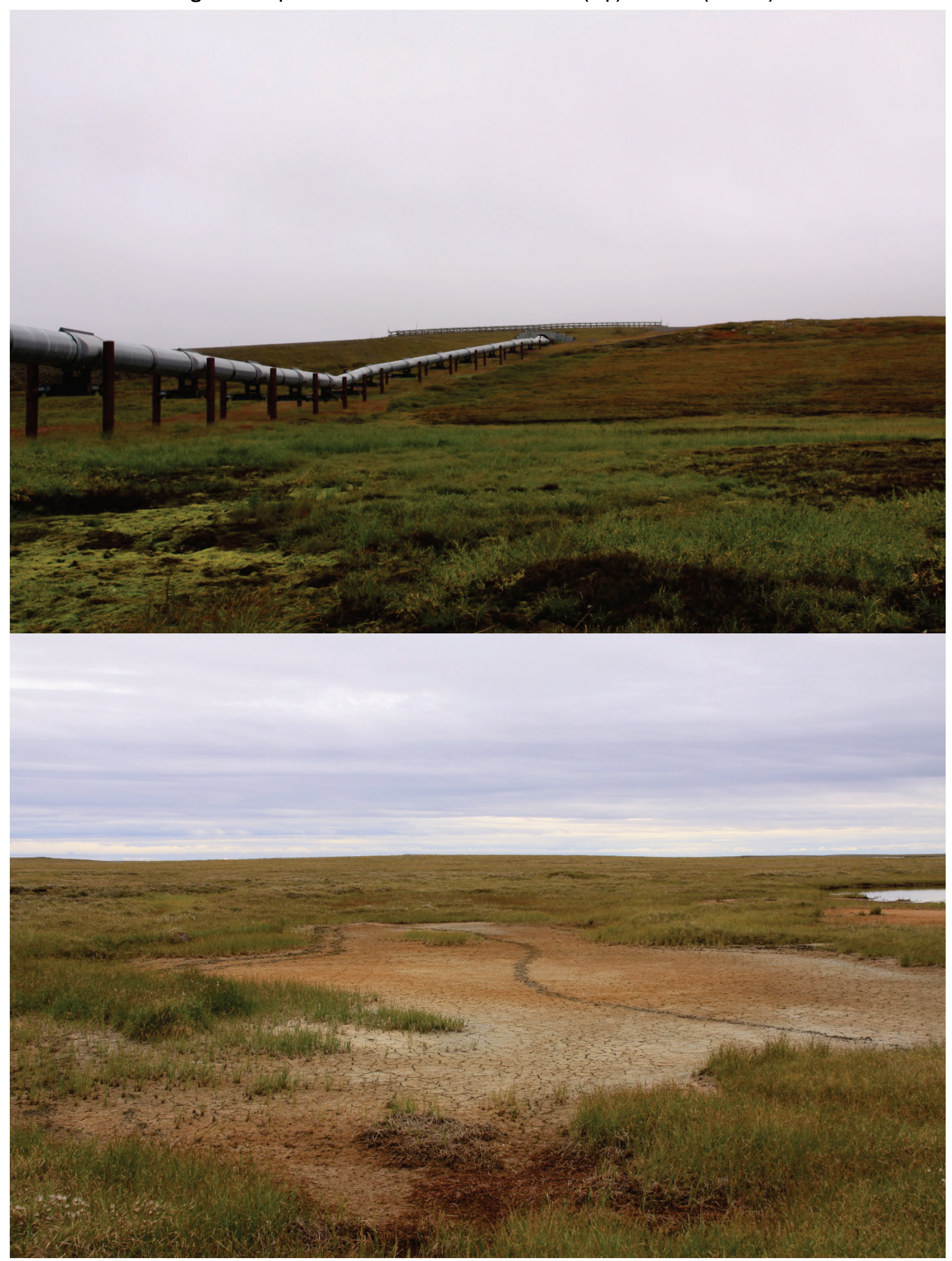


Figure 8. Lacustrine fringe dominated by Arctophila fulva (top) and tidal fringe wetlands containing Puccinellia spp. (bottom).
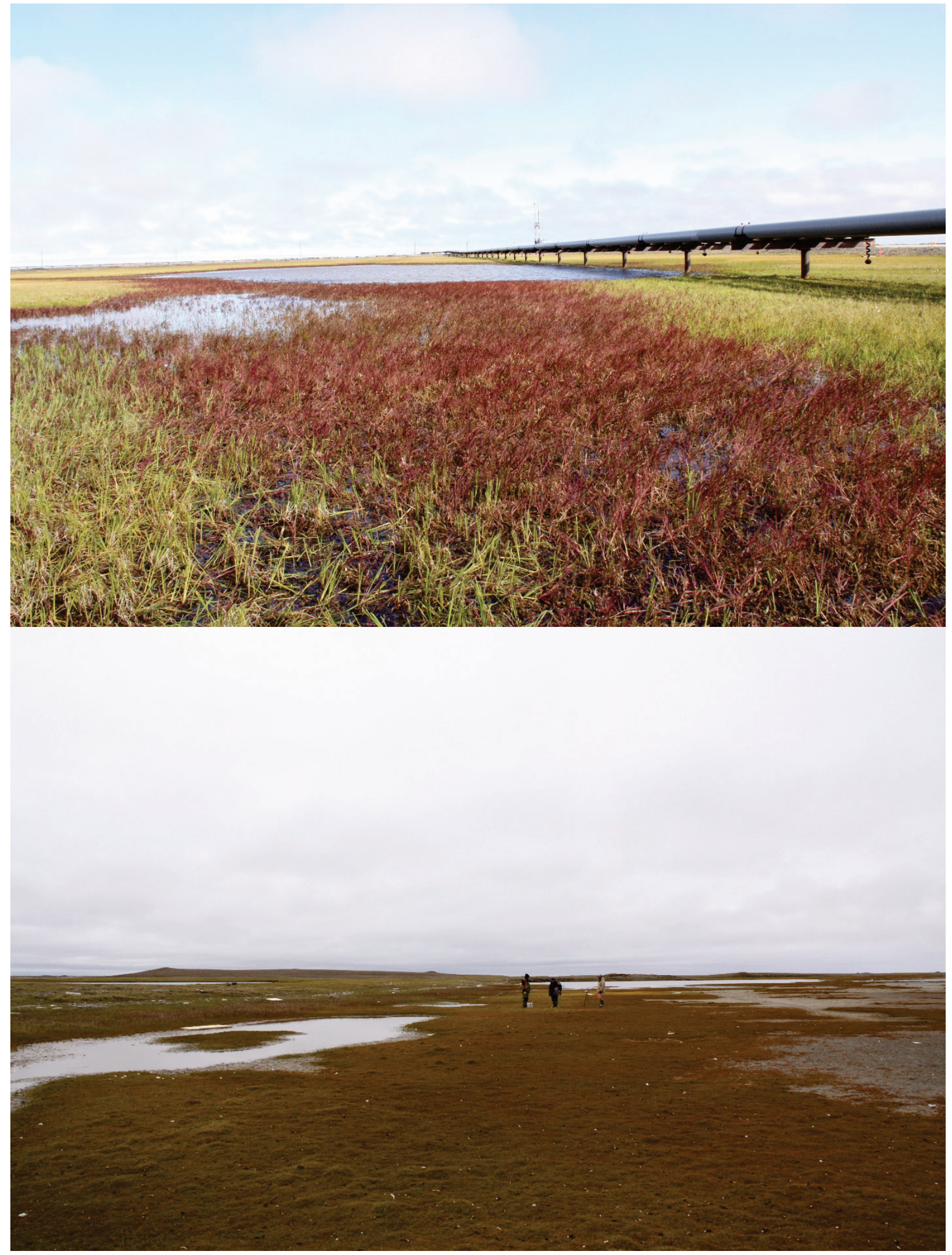
Lacustrine fringe wetlands are adjacent to lakes where the water elevation of the lake maintains the water table in the wetland. In some cases, these wetlands consist of a floating mat attached to land. Additional sources of water are precipitation and groundwater discharge; the latter dominates where lacustrine fringe wetlands intergrade with uplands or slope wetlands. Surface water flow is bidirectional and usually controlled by water level fluctuations such as seiches in the adjoining lake. Lacustrine fringe wetlands are indistinguishable from depressional wetlands where the size of the lake becomes so small relative to fringe wetlands that the lake is incapable of stabilizing water tables. Lacustrine wetlands lose water by flow returning to the lake or ocean after flooding, saturation surface flow, and evapotranspiration. Organic matter normally accumulates in areas sufficiently protected from shoreline wave erosion. Typical plant communities are dominated by four-leaf mares tail (Hippuris tetraphylla) and pendant grass (Arctophila fulva) (Shafer 1998).

\subsubsection{Slope}

Throughout the North Slope, slope wetlands occur where (1) there are slope breaks (i.e., topographic position within the landscape) or (2) geologic conditions result in the discharge of groundwater into the wetland (Figure 9). Seasonally or permanently frozen soil layers may maintain high water tables during portions of the growing season, resulting in the formation of slope wetlands on a variety of elevation gradients ranging from steep hillsides to slight slopes. Shallow groundwater or interflow discharging at the land surface provides the dominant water source in slope wetlands areas that contain permafrost; this includes water held above frozen soil. Direct precipitation contributes as a secondary hydrologic source. Slope wetlands can be confused with flats wetlands; however, in flats wetlands, precipitation in combination with melting snow and ice represent the primary water source. In slope wetlands, the dominant hydrodynamics occur downslope as unidirectional flow at or just below the soil surface. Slope wetlands lose water mainly through surface flow, shallow subsurface flow, and evapotranspiration. The convergence of flows occurs in zones at the margin of incipient channels that receive water from more than one direction. 
Figure 9. Slope wetland located within the AF region.

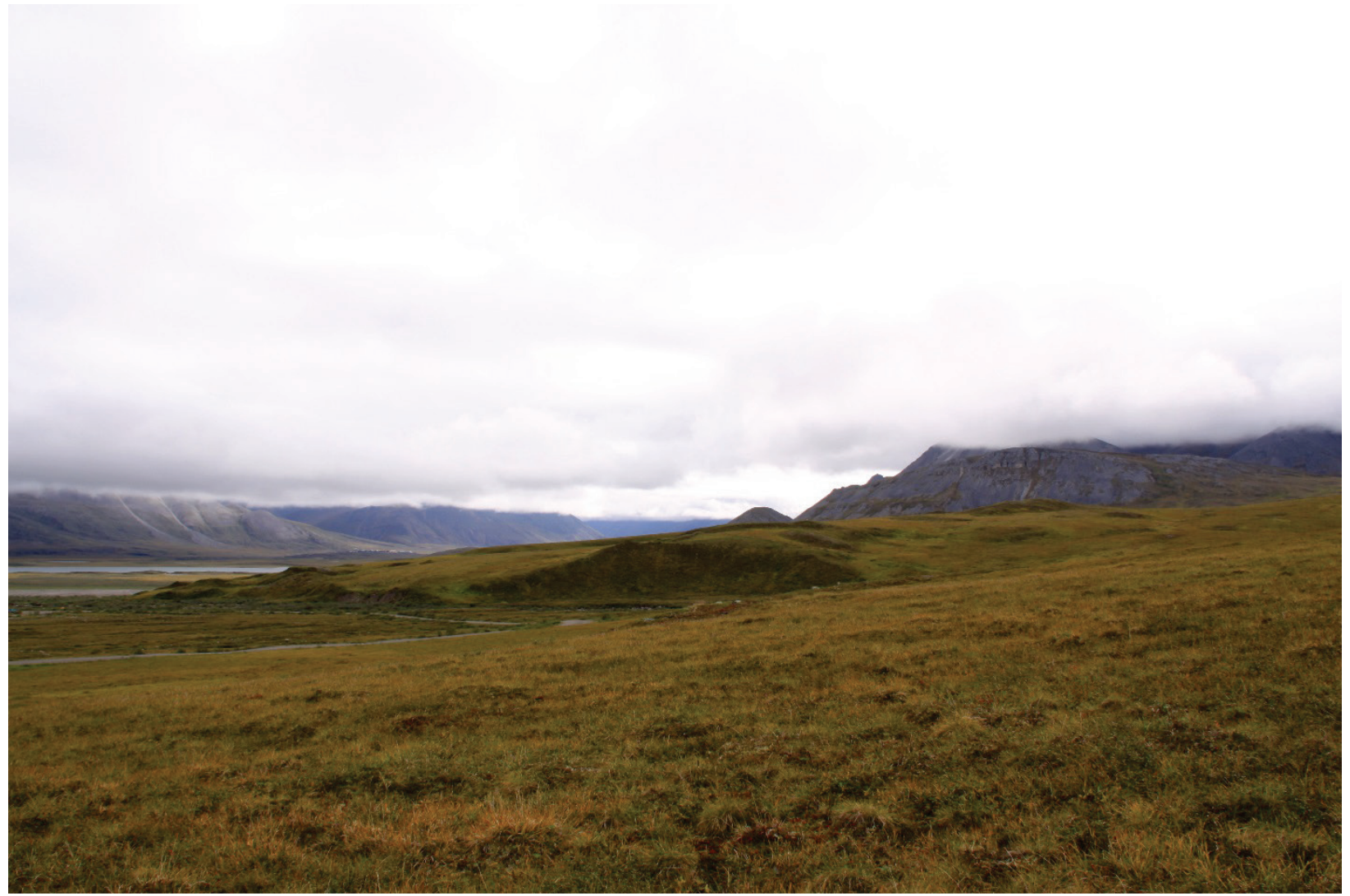

\subsection{Description of the North Slope region}

The North Slope is largely comprised of undeveloped lands including wildlands interspersed with sparsely populated settlements, hunting camps, and native Alaskan villages including Anaktuvuk Pass, Atqasuk, Utqiagvik, Kaktovik, Nuiqsut, Point Hope, Point Lay, and Wainwright. Development and infrastructure occurs within the ACP, including the Prudhoe Bay oil field complex, the northern portion of the Trans-Alaska Pipeline, and the Dalton Highway (i.e., Haul Road) (USDA NRCS 2004).

Traditional land use within the North Slope consists of subsistence hunting, fishing, and gathering. Current land use changes that directly or indirectly impact wetlands in the region include the construction of roads and ice roads, gravel mines and pads, air strips, and other infrastructure; ATV trails; dust from roads and other activities; oil and gas development; surface water extraction; impoundments; improved drainage activities; and expansion of villages and hunting camps. Potential ecological impacts due to land use include activities that bury or disturb organic soil surface layers that insulate and protect underlying permafrost layers, which lead 
to the development of thermokarst. Thermokarst, a form of periglacial topography that resembles karst and has hollows that are produced by the selective melting of permafrost, results from permafrost instability. Development of thermokarst leads to degradation of soil structure and an increase in surface water ponding, which affects albedo, vegetative communities, local hydrology, and nutrient cycling. Other land use changes that impact albedo, the proportion of the solar radiation reflected upon the Earths' surface, also have the capacity to alter soil stability. Any activity that disturbs surface organic layers and disrupts thermal balance within the soil has the capacity to impact soil stability and wetlands functions including habitat, hydrology, and biogeochemical cycling (Davis 2001). Additionally, oil spills and other sources of pollution resulting from industrial development within the region are major concerns.

\subsection{Physiography}

The AF is comprised of gently rolling hills that extend along the northern border of the Brooks Range, a 1,100 km (700 mi) east-west mountain range that is the northern extension of the northern Rocky Mountains (Wahrhaftig 1965; USDA NRCS 2004). The topography of the AF ranges from broad, rounded hills to nearly level basins and river valleys (USDA NRCS 2004). The ridges, buttes, and mesas, comprised of sedimentary rocks, divide the alluvial valleys and areas characterized by glacial moraine. The AF encompasses an area of approximately 11 million square kilometers (MLRA 245) (USDA NRCS 2004). Fresh water lakes and streams occur throughout the AF, with some of the streams freezing solid each winter. Large aufeis deposits, sheets of ice that form during winter months when successive flows freeze along stream banks and river valleys, last into the summer months in some areas (ADFG 2006; USDA NRCS 2004). Elevation in the AF ranges from $200 \mathrm{~m}$ (655 feet) at the northern boundary with the ACP to about $610 \mathrm{~m}(2,000$ feet) in the southern part located along the border with the Northern Brooks Range Mountains.

The ACP consists of level to gently rolling plains rising from the Beaufort Sea and extending southward to the AF (Wahrhaftig 1965). It is dotted with thousands of small to medium-sized lakes and interconnecting wetlands (NSSI 2013). Numerous lakes characterize the area, many of which are elongated thaw lakes that are oriented north-northwest. The elevation ranges from sea level to $200 \mathrm{~m}$ (656 feet). 


\subsection{Climate}

The AF is characterized by a dry, polar climate that has short growing seasons and long, cold winters (NSSI 2013). Average annual temperatures range from -12.2 to $-7.8^{\circ} \mathrm{C}\left(10-18{ }^{\circ} \mathrm{F}\right)$, with colder temperatures occurring at higher elevations (USDA NRCS 2004). Average annual precipitation varies from less than $254 \mathrm{~mm}$ (10 in) at lower elevations, to $381-508 \mathrm{~mm}$ (15-20 in) at higher elevations to the south. Average annual snowfall ranges from $102-152 \mathrm{~cm}$ (40-60 in) with fewer than 10 days to 55 days of frost-free period ranges. The growing season is characterized by the period during which direct observation of vegetation green-up, growth, and maintenance occur both above and below ground (USACE 2007). In the absence of direct observations, Markon (2001) estimated the growing season within the AF to occur June 7 through September 21.

The ACP is also characterized by a dry, polar climate that has short growing seasons and long, cold winters. Within the interior ACP, temperatures are slightly warmer in summer months and increased seasonal moderation occurs closer to the coast (NSSI 2013). The average annual temperature ranges from -15 to $-10{ }^{\circ} \mathrm{C}\left(8\right.$ to $\left.14{ }^{\circ} \mathrm{F}\right)$. Although freezing temperatures are possible any month of the year, the ACP experiences an average of 5 to 20 frost-free days per year. Average annual precipitation ranges from 102-152 $\mathrm{mm}$ (4-6 in), with average annual snowfall ranging from 50-102 cm (20-40 in). As described above, direct observation best determines vegetative growth; however, estimated growing season dates within the ACP occur June 20 to September 18 (Markon 2001; USACE 2007). Winds can cause drifting of snow across portions of the ACP and AF.

\subsection{Soils}

The soil order that dominates the reference domain is Gelisols, which comprise approximately 95\% of the region (USDA NRCS 2006). Gelisols are characterized by the presence of permafrost within the upper $2 \mathrm{~m}$ of the soil surface (Davis 2001; Buol et al. 2011). Permafrost plays an important role in the vegetation, hydrology, fauna, and overall function of wetlands within the reference domain. Entisols, Inceptisols, and other soil orders comprise less than $1 \%$ of the region's soil types; nonsoil areas (e.g., rock or ice) account for $4 \%$ of the landscape. The soils in this area possess a pergelic soil temperature regime, with most having an aquic soil 
moisture regime and mixed mineralogy. Soils are generally shallow to moderately deep over permafrost (Bridgham et al. 2001).

Soil microbes use carbon compounds found in organic matter as an energy source. However, the rate at which soil microbes utilize organic carbon is considerably lower in a cold, saturated, and anaerobic environment than under aerobic conditions (Reddy and DeLaune 2008). Therefore, in the seasonally thawed and saturated soils of the reference domain, partially decomposed, organic matter accumulates. The result is often the development of thick organic layers, such as peat or muck, or dark, organic-rich mineral layers with underlying layers remaining seasonally or permanently frozen. Underlying soil layers often consist of permanently frozen silt loams, which are frequently associated with large amounts of gravel and other coarse materials (Buol et al. 2006).

\subsection{Hydrology}

The $\mathrm{AF}$ and $\mathrm{ACP}$ contain many rivers that originate in the Brooks Range (ADFG 2006). Rivers are often confined to a single, moderate gradient, meandering channel, with braided channels occurring in low gradient areas. The Colville River is the largest drainage in the region, with other major rivers also in the region including the Canning and Sagavanirktok Rivers (USDA NRCS 2004). The ACP consists of thousands of small to medium-sized lakes. Many of the lakes within the ACP are elongated thaw lakes that are principally oriented north-northwest (NSSI 2013). The AF region contains fewer lakes than the ACP. The majority of the lakes within the reference domain remain shallow with typical depths less than $2 \mathrm{~m}$.

The presence of permafrost plays a major role in maintaining the wetland hydrology of the region. As seasonal thaw occurs, saturation and inundation of upper soil horizons is common and result in the formation of a seasonal active layer. The underlying permafrost provides a shallow, restrictive layer allowing the surface water table to perch for extended periods of time. As a result, the region is predominantly wetlands. Hydrologic sources within the reference domain include seasonal flooding along rivers and streams, snowmelt, direct precipitation, shallow groundwater discharge, and coastal flooding. Wetland hydrology is more prevalent in the early summer following spring thaw, break up, associated sheet flow over the land surface, and overbank flooding from streams and rivers. Evapotranspiration peaks in August, although near-surface saturation commonly predominates throughout much of the growing season. 


\subsection{Vegetation}

The $\mathrm{AF}$ is dominated by expanses of shrub-sedge tussock tundra with willow (Salix spp.) thickets along rivers and dryas (Dryas spp.) tundra along ridges. Bare soil and bedrock also occur in the region with lichens and scattered herbaceous vegetation. Mesic areas, with deeper soils (e.g., depressions and saturated sites) consist of willow (Salix spp.), ericaceous scrub-shrub, mesic graminoid herbaceous communities, and tussock forming sedges. Valleys within the AF consist of a mix scrub-shrub vegetation that is dominated by willow (Salix spp.), dwarf birch (Betula nana), and alder (Alnus spp.), among others.

The ACP supports vegetation that is primarily adapted to wet soil and cool climatic conditions, which consist of sedges, sedges-grasses, and sedgemoss meadows (USDA NRCS 2006). Floodplain vegetation consists of willow scrub-shrub and scattered herbaceous vegetation. Commonly observed, non-floodplain areas support dwarf shrub conditions with dryas, black crowberry (Empetrum nigrum L.), ericaceous shrubs, and dwarf willow. Thin, rocky soils support lichen and low-growing herbaceous vegetation, with bare soil and bedrock in some locations.

\subsubsection{Land cover types}

In 2013, the NSSI produced a land cover map defining 24 land cover types that represent approximately 24 million hectares (ha) (60 million acres) occurring north of the Brooks Range (Figure 10). The four most prevalent land cover types were: tussock shrub tundra (24\%), tussock tundra (12\%), dryas dwarf shrub (10\%) and wet sedge meadow tundra (9\%), accounting for approximately $55 \%$ of the total area. The vegetation associated with each of these common land cover types is described below. Table 1 provides a comparison chart for interpolating between NSSI data and the HGM classification system. 
Figure 10. North Slope Land Cover types (NSSI 2013).

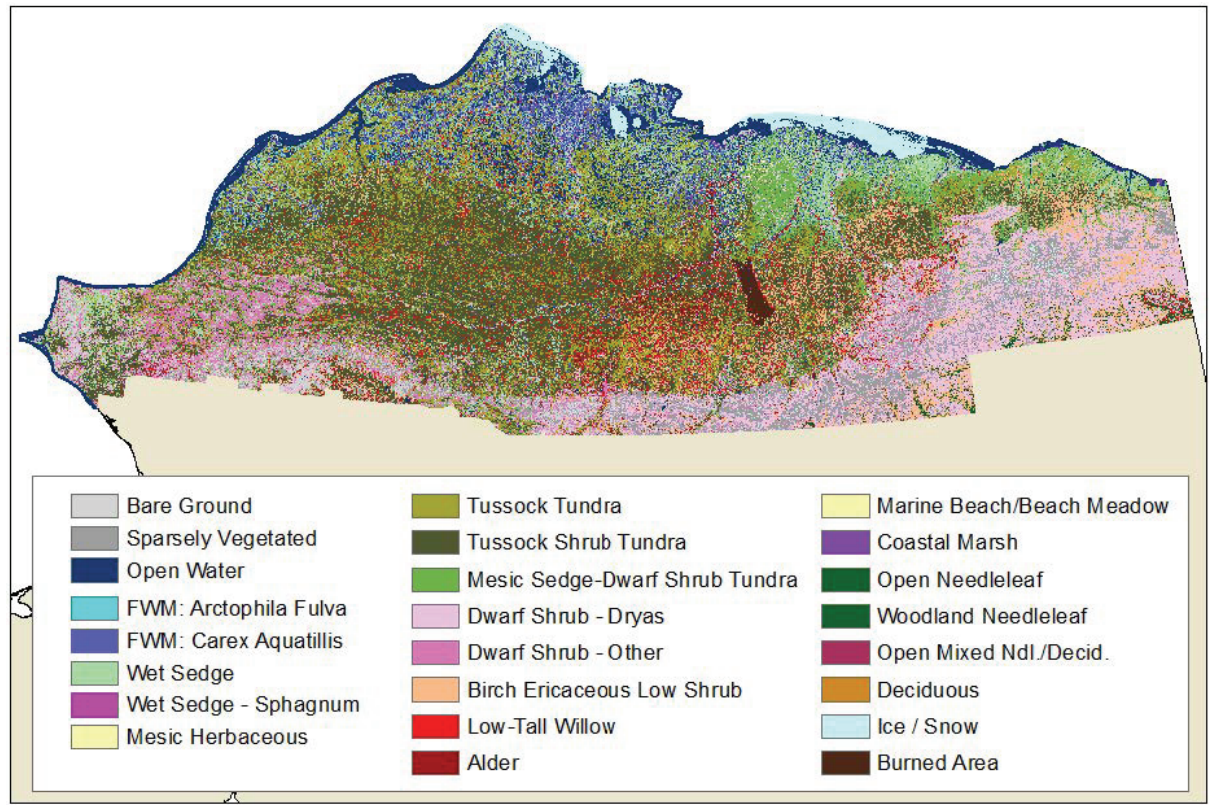

The tussock shrub tundra land cover type occupies approximately $24 \%$ of the landscape. This cover type occurs within both the ACP and AF (Viereck et al. 1992; NSSI 2013). Common plant communities include dwarf birch (Betula nana), diamond-leaf willow (Salix pulchra), marsh Labrador-tea (Rhododendron tomentosum) and bog blueberry (Vaccinium uliginosum) (NSSI 2013). Tussock-forming vegetation is primarily tussock cotton-grass (Eriophorum vaginatum) with Bigelow's sedge (Carex bigelowii) in some areas. Shrub/subshrub species include low-bush cranberry (Vaccinium vitis-idaea) and black crowberry. Forbs often include field horsetail (Equisetum arvense) and cloudberry (Rubus chamaemorus). Nonvascular plants include sphagnum (Sphagnum spp.), splendid feather moss (Hylocomium splendens), turgid aulacomnium moss (Aulacomnium turgidum), and elongate dicranum moss (Dicranum elongatum). Water sedge (Carex aquatilis), tall cotton-grass (Eriophorum angustifolium) or Chamisso's cotton-grass (Eriophorum chamissonis) are observed on highcentered and low-centered polygons.

The tussock tundra land cover type occupies $12 \%$ of the landscape, and occurs within both the ACP and the AF (NSSI 2013). This cover type is similar to the tussock shrub tundra, with the addition of bog blueberry added to the presence of shrub species. This cover type includes tussock cotton-grass as the primary tussock-former, with spruce muskeg sedge sometimes occurring as dominant or co-dominate. On high-centered and low-centered polygons, water sedge, tall cotton-grass or Chamisso's 
cotton-grass occur. Nonvascular species include sphagnum, splendid feather moss, turgid aulacomnium moss, and elongate dicranum moss.

The dryas dwarf shrub land cover type occupies $10 \%$ of the landscape. This cover type occurs primarily within the $\mathrm{AF}$, but is observed in some portions of the ACP (NSSI 2013). The vegetation of this land cover type includes eight petal mountain-avens (Dryas octopetala) on upper floodplain terraces, entireleaf mountain-avens (Dryas intergrifolia) on ridges and sideslopes, white arctic mountain heather (Cassiope tetragona), alpine bearberry (Arctostaphylos alpina), bog blueberry, and net vein willow (Salix reticulata), field horsetail, and Canadian singlespike sedge (Carex scirpoidea). Non-vascular species include rhytidium moss (Rhytidium rugosum), splendid feather moss, navel lichen (Umbilicaria spp.), racomitrium moss (Racomitrium lanuginosum) and biological soil crusts.

The wet sedge land cover type occupies $9 \%$ of the landscape. This cover type is common in both the AF and ACP (NSSI 2013). Within the ACP, this cover type dominates the low-centered polygons. In the AF, wet sedge communities occur in areas of enhanced soil moisture due to shallow groundwater within regions of permafrost. Vegetation in the AF is dominated by water sedge, tall cotton-grass, or creeping sedge (Carex chordorrhiza). At the perimeter of the low-centered polygons, shrub species occur and include dwarf birch, Alaska bog willow (Salix fuscescens), bog blueberry, and bog rosemary (Andromeda polifolia). Common non-vascular species include aulacomnium mosses, scorpidium moss (Scorpidium scorpioides), drepanocladus moss (Drepanocladus spp.), and sphagnum moss.

Low-centered polygon interiors are often dominated by water sedge and tall cotton-grass, while the elevated perimeters support low shrubs and tussocks. Common shrub species include dwarf birch, diamond-leaf willow, marsh Labrador tea, low-bush cranberry, and black crowberry. Sedges include tussock cotton-grass and Bigelow's sedge. Non-vascular plant species include sphagnum, polytrichum moss (Polytrichum strictum), and splendid feather moss.

\subsection{Fauna}

The North Slope provides habitat to a diverse array of wildlife (USDA NRCS 2004; ADFG 2006) (Figures 11-17). The wetlands within the domain provide important pre-breeding, nesting, brood-rearing, and fall staging 
habitats for over 8 million breeding and migrating birds (Johnson and Herter 1989; USDOI-BLM 2012). Birds migrate to the region for abundant summer food resources, long day length, and reduction in predator density and parasite vulnerability compared to more southern habitats (Boelman et al. 2015). Over 90 species of birds, including seabirds, loons, waterfowl, shorebirds, raptors, passerines, and ptarmigan occur within the reference domain. A majority of these species are present only during the nesting season (late May through October). Examples of nesting waterfowl species include Greater White-fronted (Anser albifrons), Snow (Chen caerulescens), and Brant Geese (Branta benicla); Tundra Swans (Cygnus columbianus); Common (Somateria mollissima), King (S. spectabilis), and Spectacled eiders (S. fischeri); and Yellow-billed Loons (Gavia adamsii). Additionally, the bulk of the U.S. breeding population of Long-billed Dowitcher (Limnodromus scolopaceus), Dunlin (Calidris alpina), and Semipalmated (C. pusilla), Pectoral (C. melanotos), Buff-breasted (Tryngites subruficollis) and Stilt Sandpipers (C. himantopus) nest in the region. Collectively, more than 6 million birds are estimated to breed on the National Petroleum Reserve-Alaska alone (ADFG 2006). Some species, such as rock (Lagopus muta) and willow ptarmigan (L. lagopus), common raven (Corvus corax), gyrfalcon (Falco rusticolus), and snowy owl (Bubo scandiacus) may occur in the area year round.

Figure 11. A gray wolf (Canis lupus) traversing a depression wetland habitat within the AF.

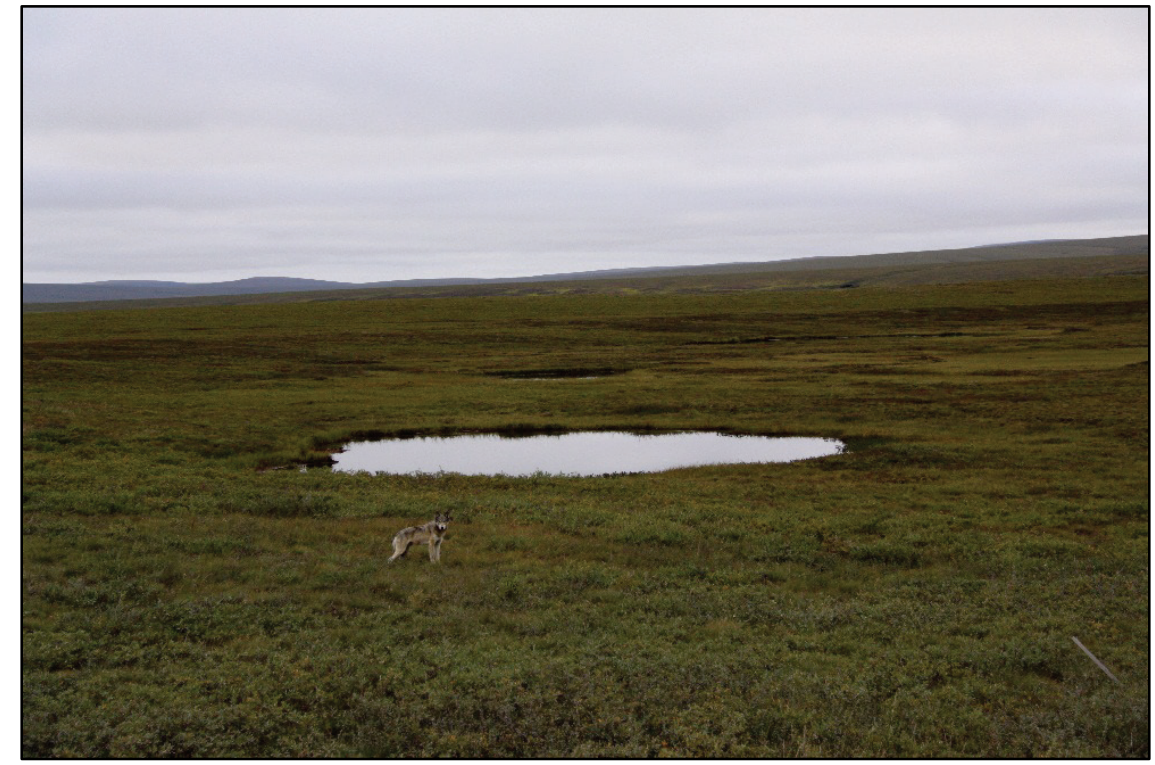


Figure 12. A tundra swan (Cygnus columbianus) feeding adjacent to a lacustrine fringe wetland of the ACP.

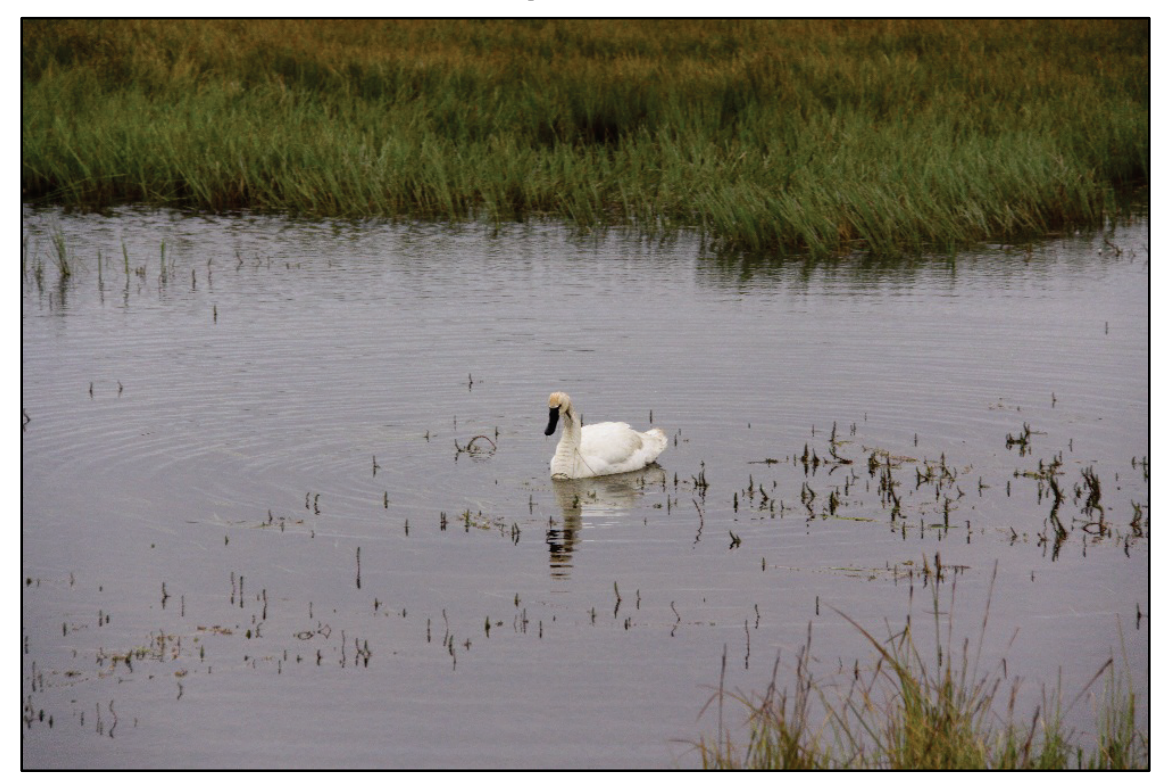

Figure 13. Caribou (Rangifer tarandus) moving across a tidal fringe wetland near the Beaufort Sea within the ACP.

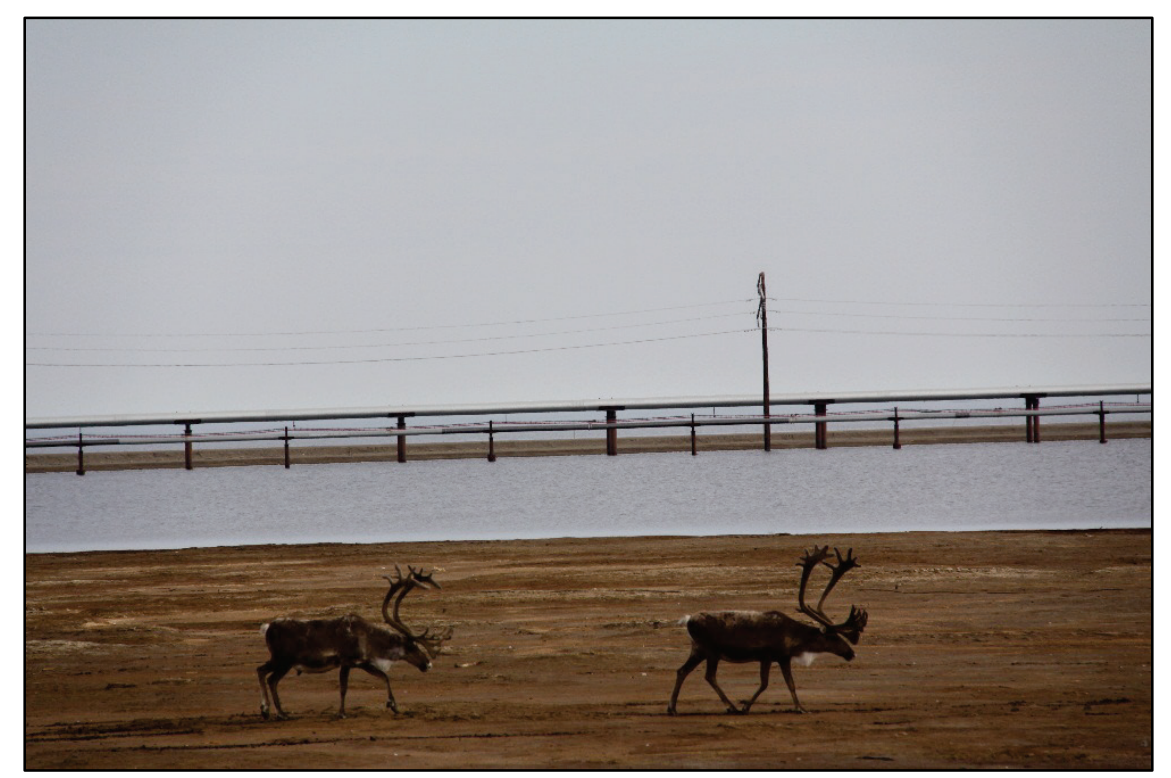


Figure 14. An Arctic Fox (Vulpes lagopus) outside its den site adjacent to a lacustrine fringe wetland within the ACP.

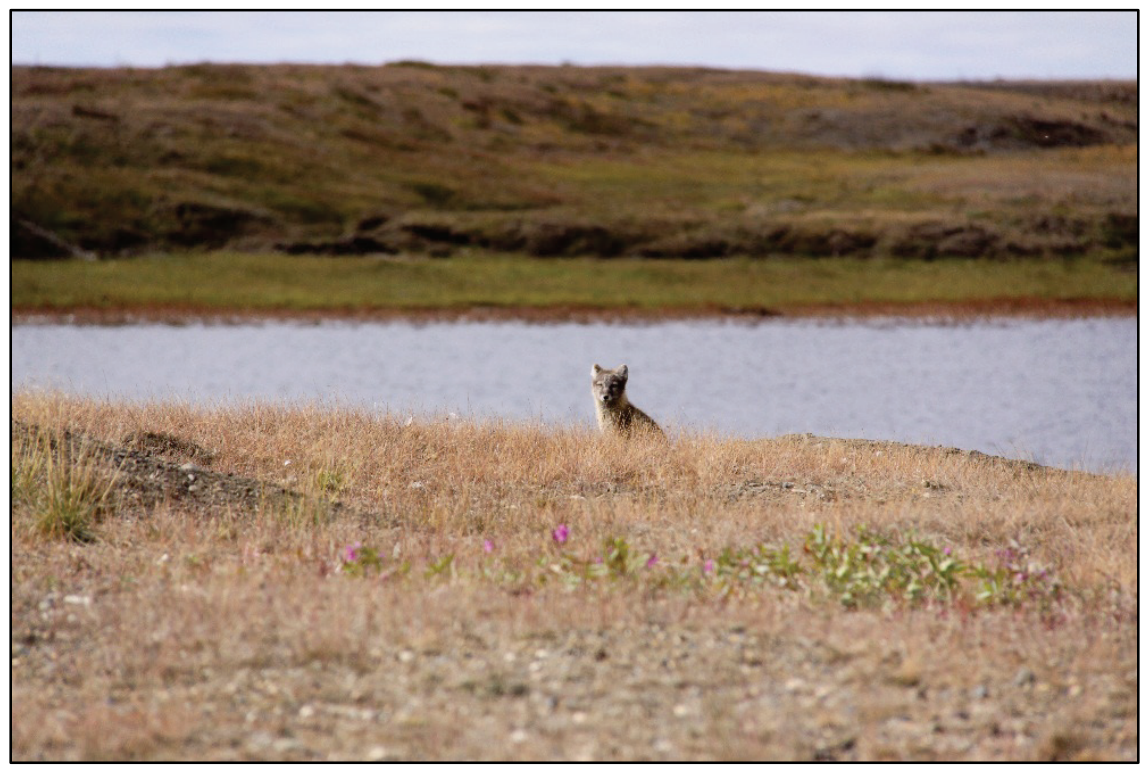

Figure 15. Muskoxen (Ovibos moschatus) in a flats wetland adjacent to the Dalton Highway within the ACP.

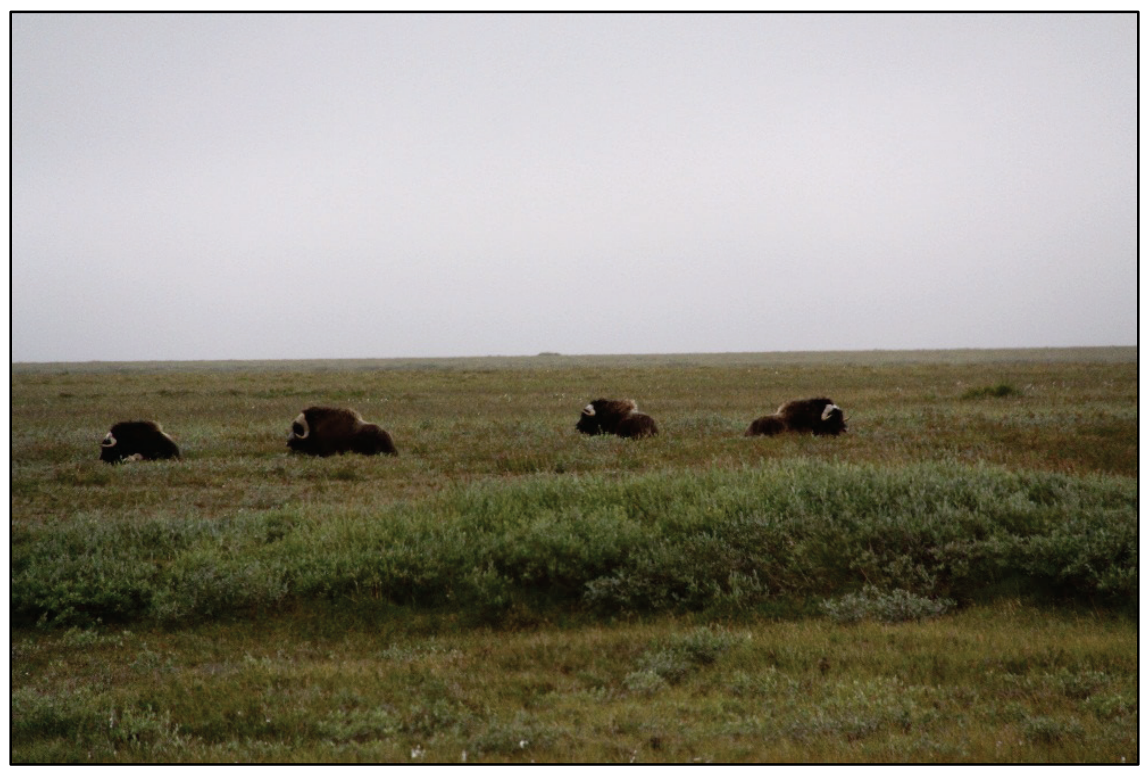


Figure 16. A brown bear (Ursus arctos) drinking from a pool adjacent to a riverine wetland near the Dalton Highway within the AF Region.

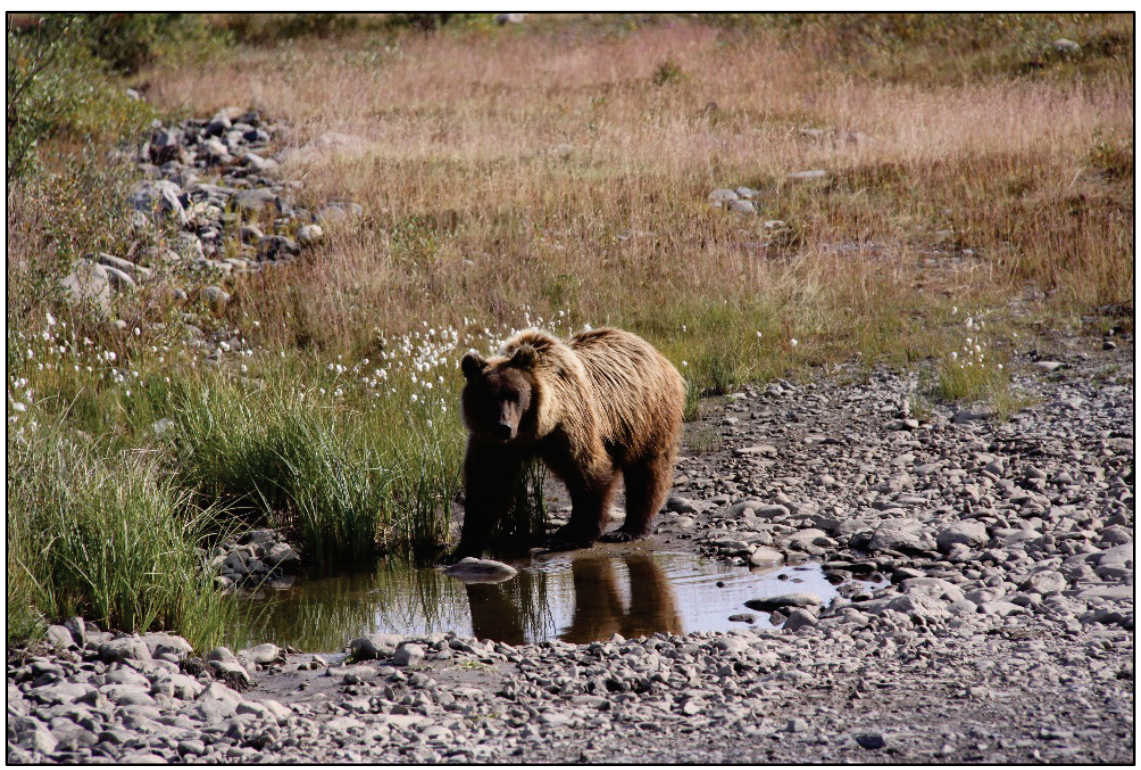

Figure 17. A Ptarmigan (Lagopus sp.) hiding within a slope wetland within the AF.

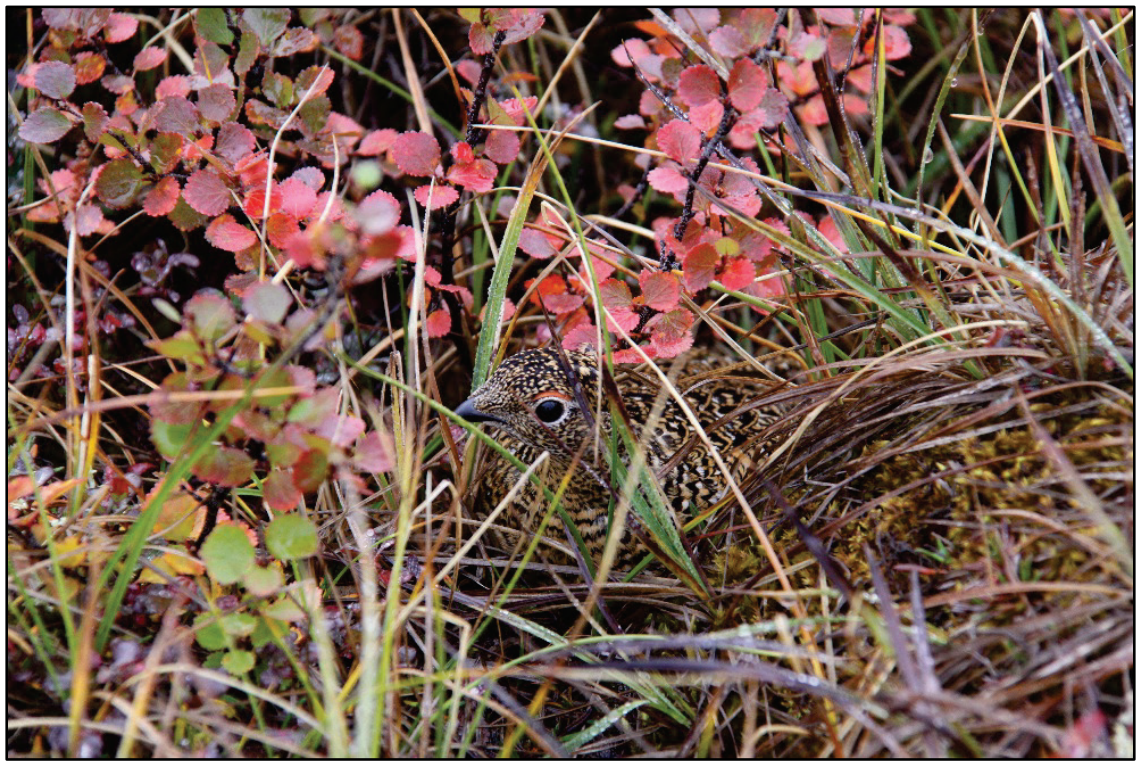

The AF provides important habitat for an array of fauna, which includes offering den sites for bears and wolves and supplying important habitat for muskoxen (Ovibos moschatus), arctic ground squirrels (Spermophilus parryii), Smith's Longspurs (Calcarius pictus), and Peregrine falcons (Falco peregrinus). The moist tundra habitat of the foothills offers nesting habitat for Baird's (Calidris bairdii) and Stilt and Buff-breasted Sandpipers, with Ptarmigans and Long-tailed Jaegers (Stercorarius 
longicaudus) transitioning from the AF to the ACP to breed. The tundra environment of this region also provides nesting habitat for small mammals including the insular vole (Microtus abbreviatus).

Several caribou (Rangifer tarandus) herds utilize the North Slope and remain an important species for subsistence hunting in this region (ADFG 2006). The Central Arctic caribou herd calves on the ACP and seek a mosquito-relief habitat along the coast during summer months. The Teshekpuk Lake Caribou herds generally calve closer to the coast near Teshekpuk Lake. The Porcupine herd calves east of the Canning River on the ACP and move inland to foothills post-calving. The Western Arctic herd uses the windier foothills of the western portion of the domain for calving and mosquito-relief habitat (USDOI-BLM 2012). Lakes within the AF contain Arctic char (Salvelinus alpinus), lake trout (S. namaycush), and whitefish (Coregonus sp.). Along the west coast, larger rivers provide spawning habitat for Dolly Varden char (Salvelinus malma) and five species of Pacific salmon (Oncorhynchus spp.) (ADFG 2006).

The ACP provides important habitat for muskox, wolverine (Gulo gulo), moose (Alces alces), lemmings (Lemmus lemmus), polar bears (Ursus maritimus) and arctic foxes (Vulpes lagopus) near the coast, with gray wolves and brown bears (Ursus arctos) found throughout (USDOI-BLM 2012). Barren ground shrews (Sorex ugyunak), singing voles (Microtus miurus), and arctic ground squirrels also inhabit the ACP. Coastal waters offer habitat for walruses (Odobenus rosmarus), minke (Balaenoptera acutorostrata), beluga (Delphinapterus leucas), gray (Eschrichtius robustus), and bowhead (Balaena mysticetus) whales, as well as bearded (Erignathus barbatus), spotted (Phoca largha), and ringed (Pusa hispida) seals. Many lakes, rivers, and streams in the region do not freeze completely, providing habitat for Arctic grayling (Thymallus arcticus), Arctic cisco (Coregonus autumnalis), broad whitefish (C. nasus), least cisco (C. sardinella), and Dolly Varden char in overwintering areas. 


\section{Assessment Variables, Functions, And Assessment Equations}

Data supporting the development and calibration of this rapid wetland assessment were collected at 88 sampling areas within the North Slope. The sampled wetland areas encompassed each of the wetland classes described above and exhibited the range of alterations reported by the development team. The remote nature of the region and the short growing season limits the time period during which on-site data can be collected. As a result, the rapid assessment method allows for either (1) an assessment based upon off-site data (remote sensing and desktop tools) only or (2) an assessment using a combination of on-site (field collected data) and off-site data collection. This approach provides a tiered structure, in which the best available data are utilized to determine assessment scores. A site visit allows for verification of the accuracy of off-site data and accounts for recent changes that may potentially affect wetland assessment outcomes in the area of interest. USACE may require the collection of on-site data.

\subsection{Variables}

The following section introduces the variables used in the rapid assessment of wetlands within the North Slope. During the development of this guidebook, over 50 variables were evaluated for inclusion, including over 20 on-site variables and 30 off-site variables. The 13 variables selected displayed utility in differentiating between areas with varying levels of disturbance, proved efficient and easy to measure, and displayed repeatability among users. Each variable was calibrated based upon data collected within the region. The protocol provided in Section 3.0 describes specific approaches for collecting data for each variable. Variables were converted to variable subindex scores ranging from o to 1.0 using an assessment calculator. Results were then combined using empirical assessment equations to produce an assessment score for three wetland functions (habitat, hydrology, and biogeochemical cycling) and an on-site modifier (when on-site data are available).

\subsubsection{Desktop or remote sensing variables}

Off-site variables were based upon analysis of GIS tools, imagery, or other remote-sensing resources. A list of potential off-site data sources is 
presented in Appendix A, although other resources may be available. Users should utilize the most current and/or accurate data or information available. The USGS and other federal and state agencies, academia, and private sources provide a number of tools for off-site analysis. Off-site variable data are collected at two spatial scales, $80 \mathrm{~m}$ radius and $800 \mathrm{~m}$ radius surrounding a data point (Figure 18). The $80 \mathrm{~m}$ and $800 \mathrm{~m}$ radius areas were selected after evaluating a number of possible scales of data collection. The selected scales were able to account for potential wetland impacts at each of the study areas examined. The following variables were utilized to determine assessment scores for three wetland functions (habitat, hydrology, and biogeochemical cycling):

Variables assessed at the $80 \mathrm{~m}$ radius

1. Local landscape disturbance $\left(\mathrm{V}_{\text {LLD }}\right)$

2. Anthropogenically derived surface water $(\mathrm{Vsw})$

3. Impediment to hydrology $\left(\mathrm{V}_{\mathrm{IH}}\right)$

4. Evidence of dust deposition ( $\mathrm{VDD}_{\mathrm{DD}}$

5. Evidence of thermokarst $\left(\mathrm{V}_{\mathrm{TK}}\right)$

Variables assessed at the $800 \mathrm{~m}$ radius

1. Landscape disturbance $\left(\mathrm{V}_{\mathrm{LD}}\right)$

2. Impediment to wildlife ( $\left.\mathrm{V}_{\mathrm{IW}}\right)$

3. Distance to roadway ( $\left.V_{D R}\right)$

Each variable was calibrated or scaled using the data collected within the reference domain. The scaling for each off-site variable is presented in the protocols outlined below. Variable subindex scores can be calculated manually from the graphs presented in Section 3.0 or determined using the wetland assessment calculator provided. 
Figure 18. Off-site variable collection occurs at two spatial scales, with five variables $\left(V_{L L D}, V_{I H}, V_{D D}, V_{T K}\right.$, and $V_{s w}$ ) examined within an $80 \mathrm{~m}$ radius circle and three variables ( $V_{L D}, V_{I w}$, and $V_{D R}$ ) examined within a larger $800 \mathrm{~m}$ radius area that encompasses the $80 \mathrm{~m}$ radius circle. Please note that the $80 \mathrm{~m}$ radius plot is dead center of the $800 \mathrm{~m}$ radius plot.

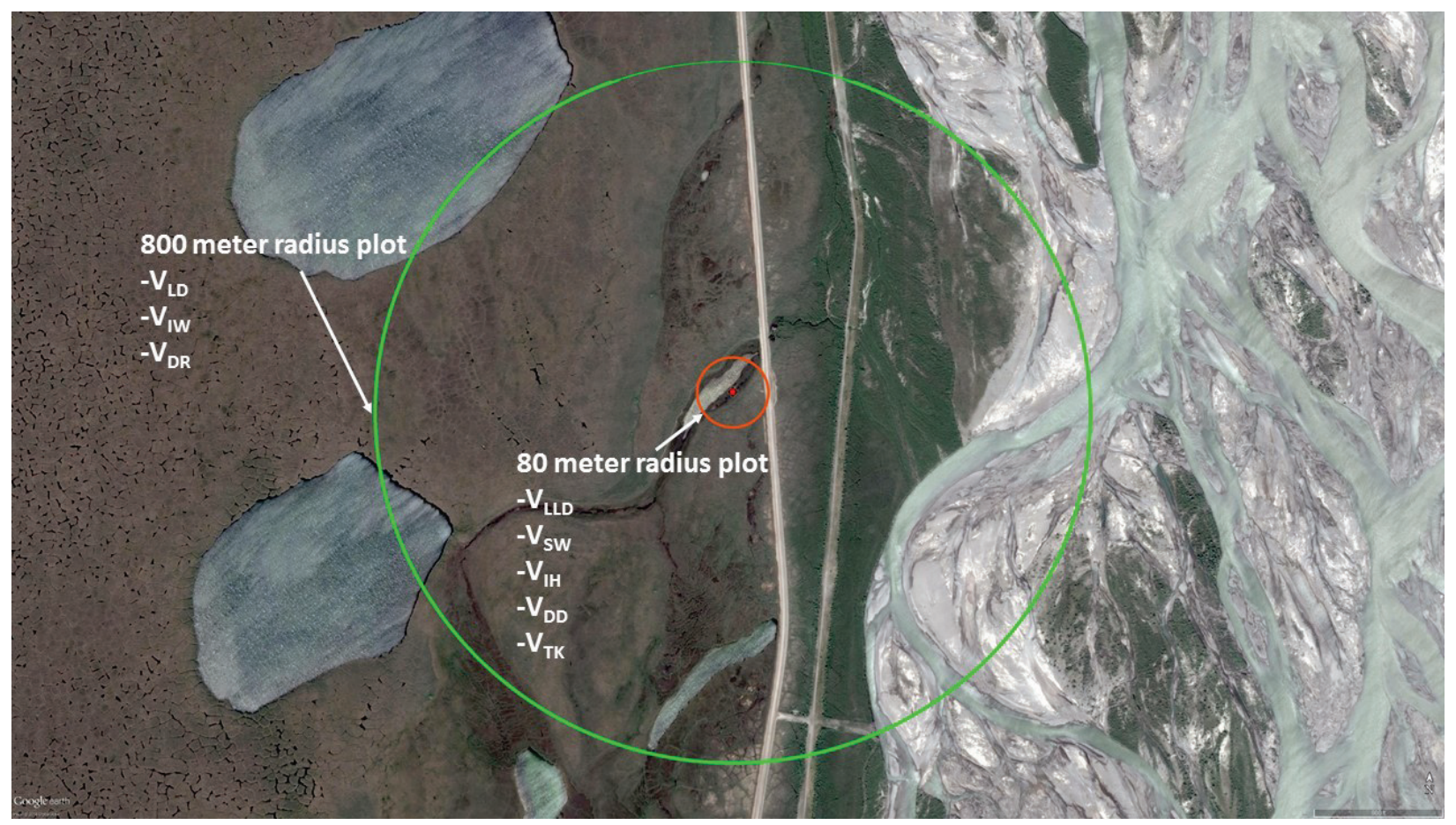

\subsubsection{On-site variables}

On-site variable data collected during the growing season were supplemented and used in conjunction with off-site variables. As a result, the on-site data should be collected in the same area utilized for the offsite data collection, but confined to the $80 \mathrm{~m}$ radius plot described above. The following variables were utilized to determine assessment scores for the on-site modifier.

1. Microtopography ( $\left.\mathrm{V}_{\mathrm{MT}}\right)$

2. Species richness $\left(\mathrm{V}_{\mathrm{SR}}\right)$

3. Bare ground $\left(\mathrm{V}_{\mathrm{BG}}\right)$

4. Local evidence of thermokarst $\left(\mathrm{V}_{\text {LTK }}\right)$

5. Local evidence of dust deposition ( $\left.\mathrm{V}_{\mathrm{LDD}}\right)$

Microtopography was collected using two $30 \mathrm{~m}$ transects. Species richness and bare ground variables are collected utilizing four $1 \mathrm{~m}$ quadrats (Figure 19). Local evidence of thermokarst and dust deposition are presence or absence determinations. 
Figure 19. Plot layout for on-site data collection. Thirty meter transects are positioned perpendicularly for the measurement of $\mathrm{V}_{\mathrm{MT}}$. A single $1 \mathrm{~m}$ quadrat should be located in a representative area within each quarter section for the measurement of $V_{S R}$ and $V_{B G}$. Observations of local evidence of both dust deposition ( $\mathrm{VLDD}_{\mathrm{LD}}$ ) and thermokarst ( $\mathrm{V}_{\mathrm{LTK}}$ ) are made throughout the sample area.

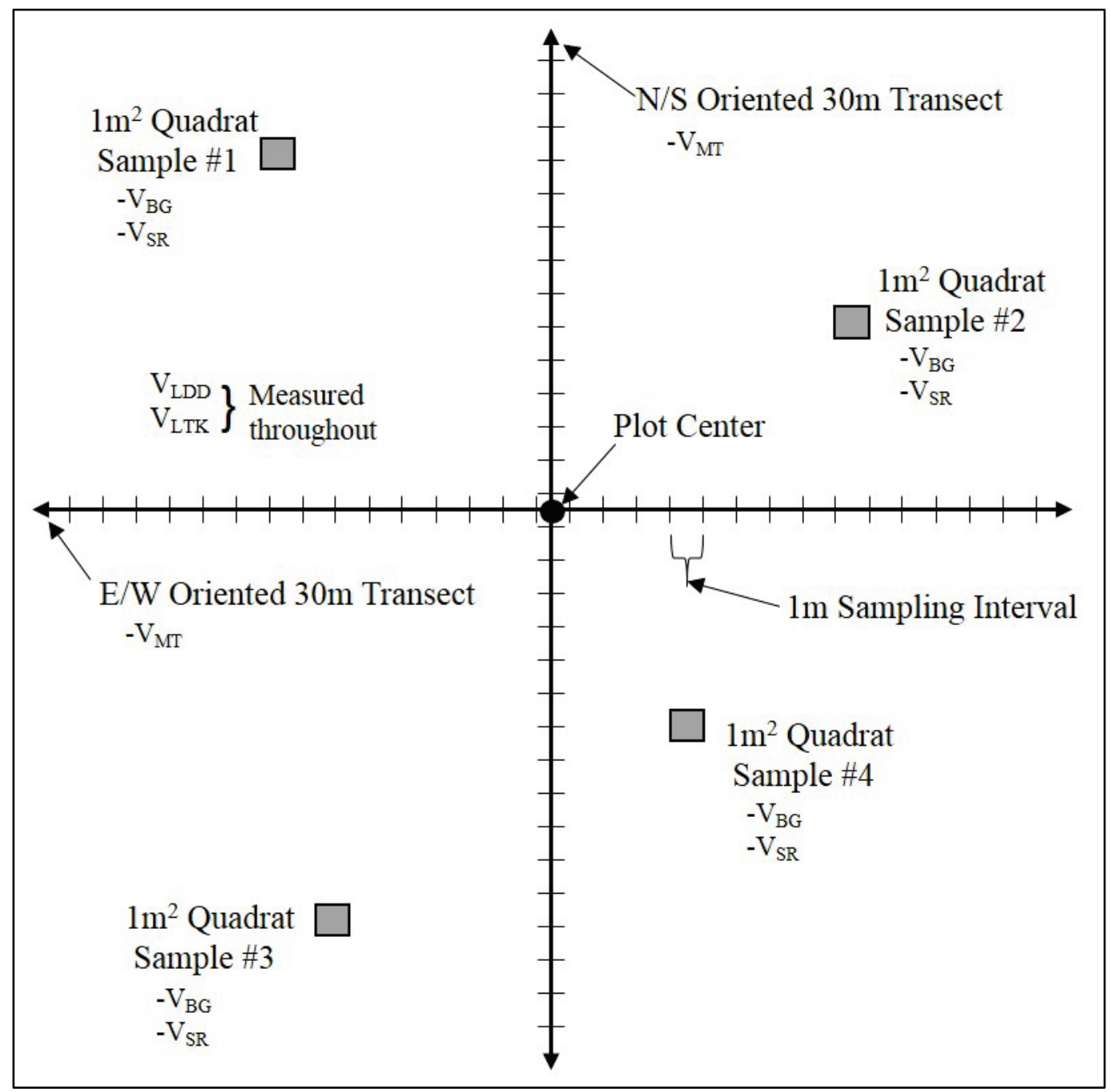

\subsection{Wetland assessment equations}

This section provides the definition, rationale, characteristics, and assessment equations utilized to quantify wetland functions (e.g., habitat, hydrology, and biogeochemical cycling) and the on-site assessment modifier when on-site data are available. Although the rapid assessment approach does not directly measure wetland functions, surrogate measures related to function have been utilized in a variety of methodologies (Smith et al., 1995; 2013). These surrogate measures have been successfully related to wetland functions in several studies (Noble et al., 2014). For example, Summers et al. (2015) demonstrated the capacity of rapid assessment approaches to 
infer habitat functions in salamander communities; Berkowitz et al. (2014) showed strong relationships between rapid assessment scores and direct measurements of biogeochemical cycling functions.

The following introduces the empirical equations utilized to calculate assessment scores and provides rationale and justification for selection and weighting of the wetland assessment. Each assessment equation was derived empirically based upon data collected within the region, direct observation of wetland functional stressors, and input from the assessment development team. The implications of dust deposition and thermokarst to wetland function are also discussed.

\subsubsection{Habitat}

The habitat function is defined as the capacity of wetlands in the region to provide critical life requisites to the vegetation and wildlife community.

The rationale for selecting the habitat function includes the fact that wetlands are recognized as valuable habitats for a diversity of plants as well as invertebrate and vertebrate animal species. Plant communities, birds, and small and large mammals were selected as the focus of this function. Birds were chosen because they are of considerable public and agency interest, and they respond rapidly to changes in the quality and quantity of their habitats. In addition, birds include diverse and unique species that have strong associations with the different ecological components that characterize wetlands in the reference domain. Birds have been shown to be sensitive indicators and integrators of environmental changes, such as those brought about by human use and alteration of landscapes (Morrison 1986, Croonquist and Brooks 1991).

Examples of potential independent, quantitative measures of this function that could be used to validate the assessment index (Smith et al. 2013) include the combined species richness of plants, birds, and mammals that use regional wetlands throughout the annual cycle. Data requirements for assessment validation include direct monitoring of wildlife communities using appropriate techniques for each taxon. Ralph et al. (1993) described field methods for monitoring bird populations.

Hydrologic or landscape alterations to wetlands have the potential to impact plant and wildlife species. Species with direct dependence on water are highly vulnerable to the placement of fill materials or to wetland 
drainage due to human developments. Even partial draining or filling could impact breeding activity because of the length of time needed for nesting, egg development, and maturation of the young. Conversely, artificially increasing the amount of time that surface water is present in a wetland by excavating, changing patterns of albedo, or by augmenting runoff into the wetland can potentially reduce the suitability for plants and animals. Sites with unaltered conditions that have not been subjected to disturbance for long periods support a characteristic vegetation composition and structure. Wildlife species have evolved with and adapted to these conditions. Thus, alterations to wetlands have the potential to change the composition and structure of the plant and wildlife community. Factors other than anthropogenic disturbance, including droughts and catastrophic storms, fire frequency and intensity, competition, disease, browsing pressure, community succession, and natural disturbances, also affect plant and wildlife communities.

Birds and other wildlife found within the region are also known to be impacted adversely by habitat fragmentation. Habitat fragmentation can impact bird nesting areas and access to calving/denning areas in other species. In addition, fragmentation may impact movement corridors to brood-rearing areas as well as access to migration routes. These factors can result in increased predation, nest parasitism, and other impacts (Kessel 1979; Liebezeit et al. 2009; Furness and Greenwood 1993; Nelleman et al. 2003). Area-sensitive species tend to have lower reproductive output in smaller habitat patches, or they simply avoid small patches altogether. Additionally, some species prefer areas characterized by a mosaic of different habitat types.

The assessment equation for habitat incorporates the following variables: Impediment to wildlife ( $\mathrm{V}_{\mathrm{IW}}$ ), Distance to roadway ( $\mathrm{V}_{\mathrm{DR}}$ ), Landscape disturbance $\left(\mathrm{V}_{\mathrm{LD}}\right)$, and Local landscape disturbance $\left(\mathrm{V}_{\mathrm{LLD}}\right)$. These variables are combined by determining (1) the minimum (MIN) score regarding Impediment to wildlife ( $\mathrm{V}_{\mathrm{IW}}$ ) and Distance to roadway ( $\mathrm{V}_{\mathrm{DR}}$ ) and (2) the arithmetic mean of Landscape disturbance $\left(\mathrm{V}_{\mathrm{LD}}\right)$ and Local landscape disturbance $\left(V_{L L D}\right)$. The two terms are then combined using a simple arithmetic mean:

$$
\text { Habitat assessment score }=\left[\mathrm{MIN}\left(\mathrm{V}_{\mathrm{IW}}, \mathrm{V}_{\mathrm{DR}}\right)+\left(\left(\mathrm{V}_{\mathrm{LD}}+\mathrm{V}_{\mathrm{LLD}}\right) / 2\right)\right] / 2
$$


The habitat assessment equation includes two equally weighted terms encompassing (1) measures of impedance to wildlife movement, such as roadways or other infrastructure and (2) the degree of landscape disturbance at both site specific and regional scales. For example, areas with high concentrations of roads, pipelines, or other infrastructure can deter or alter wildlife movements, fragment habitat, and decrease habitat quality and quantity. Potential habitat assessment scores range from 0.0 to 1.0, with higher scores corresponding to a lower degree of alteration and a higher potential to provide wetland habitat functions.

\subsubsection{Hydrology}

The hydrology function is defined as the ability of the wetlands within the region to dissipate energy associated with flow velocity, transport water down gradient, maintain natural soil moisture and surface water levels, and provide waters to streams and rivers at local and regional scales (Woo and Winter 1993; McNamara et al. 1998). Potential independent, quantitative measures that may be used in validating the hydrology function include direct measures of soil moisture, surface water flow, and/or near-surface ground water movements over time.

The rationale for selecting the hydrology function includes the fact that water transport and energy dissipation are fundamental physical functions performed by wetlands throughout the reference domain (Roulet and Woo 1986; Woo and Young 2006). The energy produced by flowing water affects the rate of microbial processes and the amount of sediment, organic matter, and nutrients that are transported down gradient (Chapin et al. 1993). A dramatic increase or decrease in surface water ponding can also impact habitat, permafrost stability, and nutrient cycling dynamics.

The characteristics and processes that influence the capacity of wetlands to dissipate energy and convey water have both natural and anthropogenic origins. Climate, landscape-scale geomorphic characteristics, and characteristics of the soil are factors largely established by natural processes (Rovansek et al. 1996). However, even landscape scale geomorphic characteristics and soils can be altered by anthropogenic alterations.

Human activities may have a profound effect on the amount, timing, and movement of water. Modifications to the landscape such as construction of fill pads, gravel mines, roads, or other infrastructure potentially modify hydrology and affect this wetland function. 
The assessment equation for hydrology incorporates the following variables: Impediment to hydrology $\left(\mathrm{V}_{\mathrm{IH}}\right)$, Anthropogenically derived surface water ( $\left.V_{S w}\right)$, Landscape disturbance $\left(\mathrm{V}_{\mathrm{LD}}\right)$, and Local landscape disturbance $\left(\mathrm{V}_{\mathrm{LLD}}\right)$. These variables are combined by determining the (1) arithmetic mean of Impediment to hydrology $\left(\mathrm{V}_{\mathrm{IH}}\right)$ and Anthropogenically derived surface water $\left(\mathrm{V}_{\mathrm{sw}}\right)$ and (2) the arithmetic mean of Landscape disturbance $\left(\mathrm{V}_{\mathrm{LD}}\right)$ and Local landscape disturbance $\left(\mathrm{V}_{\mathrm{LLD}}\right)$. The two terms are then combined using a geometric mean:

$$
\text { Hydrology assessment score }=\left[\left(\left(V_{I H}+V_{S W}\right) / 2\right) X\left(\left(V_{L D}+V_{L L D}\right) / 2\right)\right]^{1 / 2}
$$

The hydrology assessment equation includes two equally weighted terms encompassing (1) measures of impedance to hydrologic flow and the presence of anthropogenically derived surface water and (2) the degree of landscape disturbance at both $80 \mathrm{~m}$ radius and $800 \mathrm{~m}$ radius scales. For example, areas with high concentrations of infrastructure limit the mobility of surface water, resulting in ponding of water adjacent to fill pads or other structures. Potential hydrology assessment scores range from 0.0 to 1.0, with higher scores corresponding to a lower degree of alteration and a higher potential to provide wetland hydrology functions.

\subsubsection{Biogeochemical cycling}

The biogeochemical cycling function is defined as the characteristic biotic and abiotic processes of wetlands that alter the concentration and form of nutrients and compounds (Reddy and DeLaune 2008). The rationale for selecting the biogeochemical cycling function includes the fact that these processes encompass the conversion of nutrients and other elements and compounds from one form into another by assimilation into plant biomass, remineralization of those materials when the plant materials decompose, long-term storage of nutrients and compounds in mineral and organic soil fractions, and interaction between aquatic, terrestrial, and atmospheric environmental compartments. This includes the capacity of wetlands to sequester and transform carbon as well as other compounds (including pollutants) (McGuire et al. 2009). Biogeochemical functions are recognized as a primary function that should be considered in relationship to wetland impacts (Mitsch and Gosselink 2007).

A sustained supply of organic carbon in the soil provides for maintenance of characteristic plant communities including annual primary productivity, composition, and diversity (Bormann and Likens 1970). The 
plant community (i.e., producers) provides the food and habitat structure (i.e., energy and materials) needed to maintain the characteristic animal community (i.e., consumers). In time, the plant and animal communities function as a source of detritus that serve as the foundation of energy and materials needed to maintain the characteristic community of decomposers. The decomposers break down organic materials into simpler elements and compounds that can reenter the nutrient cycle (Berendse and Jonasson 1992; Jonasson et al. 1999; Jonasson and Shaver 1999).

Biogeochemical cycling is a function of biotic and abiotic processes that result from conditions within and around the wetland (Giblin et al. 1991). In wetlands, carbon is stored within, and cycled among, four major compartments: (a) the soil, (b) primary producers such as vascular and nonvascular plants, (c) consumers such as animals, fungi, and bacteria, and (d) dead organic matter. Due to the low temperatures and short growing season, wetlands in the region store large quantities of carbon, which provide carbon sequestration on a massive scale (Mack et al. 2004). Carbon storage occurs in wetlands because the oxygen needed for aerobic respiration has a rate of diffusion 10,000 times slower in water than in air. Thus, wetlands' anaerobic conditions slow the microbial decomposition of organic matter.

Many wetland plants, called hydrophytes, are unique in that they have adapted to living in water or wet soil environments. Physiological adaptations in leaves, stems, and roots allow for greater gas exchange, permit respiration to take place, and allow the plant to harvest the stored chemical energy it has produced through photosynthesis. Although there is no clear starting or ending point for carbon cycling, it can be argued that it is the presence and duration of water in the wetland that determines the characteristic plant community of hydrophytes and the rate of carbon cycling. In turn, it is the maintenance of the characteristic primary productivity of the plant community that sets the stage for all subsequent transformations of energy and materials at each trophic level within the wetland. It follows that alterations to hydrologic inputs, outputs, or storage and/or changes to the characteristic plant community will directly affect the way in which the wetland can perform this function (Frey and McClelland 2009). It should also be noted that the organic rich wetland soils in the region also play an important role in mercury cycling through the environment and the formation, storage, and distribution of methylmercury in the environment (Hammerschmidt et al. 2006). 
Abiotic processes that affect retention and cycling of nutrients and other compounds depend primarily on the adsorption of materials to soil particles, the amount of water that passes through the wetland carrying dissolved constituents, the hydroperiod or retention time of water that maintains anaerobic conditions, and the importation of materials from surrounding areas (Shaver et al. 1991; Shaver et al. 1992; Sullivan et al. 2008; Schuur et al. 2008). Natural soils, hydrology, and vegetation are important factors in maintaining these characteristic biogeochemical processes.

Measuring the rate at which carbon or other compounds are transferred and transformed between and within trophic levels would be a potential independent, quantitative measure used to validate the biogeochemical cycling function. However, the time and effort required to make these measurements are well beyond a rapid assessment procedure.

Reference data suggest that land use practices in and around the wetland have great effect on the characteristic plant community structure (i.e., species composition and coverage), diversity, and primary productivity. Changes in hydrology through filling, development of obstructions (e.g., roads, pipelines), increased surface water or ponding, or other changes can have a direct and pronounced effect on the accumulation and decomposition of soil organic matter. Soil organic matter is a characteristic that affects soil oxidation-reduction reactions. Soil alterations also change the physical features to which native plants have adapted. As a result, disturbances have the potential to influence biogeochemical interactions and function.

The assessment equation for biogeochemical cycling incorporates the following variables: Landscape disturbance ( $\left.\mathrm{V}_{\mathrm{LD}}\right)$, and Local landscape disturbance (VLLD). The biogeochemical cycling assessment score is the minimum value of these two variables:

$$
\text { Biogeochemical cycling assessment score }=\mathrm{MIN}\left(\mathrm{V}_{\mathrm{LD}}, \mathrm{V}_{\mathrm{LLD}}\right)
$$

The biogeochemical cycling assessment equation has one term describing the degree of landscape disturbance at the two scales ( $80 \mathrm{~m}$ and $800 \mathrm{~m}$ ). For example, areas with high concentrations of infrastructure have the capacity to alter both inputs and outputs of nutrients, water, gases, and other factors that influence biogeochemical cycling. Potential biogeochemical cycling assessment scores range from 0.0 to 1.0, with 
higher scores corresponding to a lower degree of alteration and a higher potential to provide wetland biogeochemical cycling functions.

\subsubsection{On-site assessment score modifier}

Collection of on-site data provide a useful tool to (1) verify determinations made using off-site analysis and (2) further refine assessment results based on using ground based measurements. As noted above, the wetland assessment can be conducted with or without the collection of on-site data. Based upon data gathered during assessment development, collection of on-site data requires $<2 \mathrm{hrs}$ per sample location, allowing for a number of on-site assessments to be completed in one day or less (Smith et al. 2013). However, the timing of an on-site assessment is limited to the growing season, when herbaceous vegetation growth can be observed. Efforts should be made to focus on-site data collection during the peak of the growing season when possible.

The on-site assessment score modifier incorporates three variables including: Species richness ( $\left.\mathrm{V}_{\mathrm{SR}}\right)$, Bare ground $\left(\mathrm{V}_{\mathrm{BG}}\right)$, and Microtopography ( $\left.\mathrm{V}_{\mathrm{MT}}\right)$. The on-site modifier score is determined using the arithmetic mean of the three variables:

On-site assessment score modifier $=\left(\mathrm{V}_{\mathrm{SR}}+\mathrm{V}_{\mathrm{BG}}+\mathrm{V}_{\mathrm{MT}}\right) / 3$

The on-site assessment score modifier contains one term, which represents the field conditions observed within the project area. Disturbances such as placement of fill material, road construction, dust, and alterations to hydrology or the stability of the permafrost layer impact on-site conditions and result in a decreased assessment score. On-site assessment score modifier values range from 0.0 to 1.0, with increasing values associated with lower levels of disturbance and a high level of ecological function.

Please note, on-site data collection may be required at the discretion of USACE.

\subsubsection{Dust deposition and the presence of thermokarst}

During development of the rapid wetland assessment, the development team indicated that dust deposition and the presence of thermokarst were important factors negatively impacting wetlands within the region. As a 
result, evidence of dust deposition and thermokarst limit the maximum attainable scores derived above for each wetland function and the on-site modifier. Dust deposition and the presence of thermokarst are evaluated at $80 \mathrm{~m}$ scale. Procedures for determining the presence of dust and thermokarst and the associated limitation of assessment scores are described in the sample protocol presented below. 


\section{Assessment Protocol}

The following section provides a systematic protocol for application of the rapid wetland assessment including instructions for the measurement of each assessment variable, guidance on determining variable subindex scores, data analysis, and interpretation of results. All data collected for use are recorded on the "Alaska North Slope Region Wetland Assessment" data form (see Section 9.0).

- Step 1. Define the wetland assessment area.

The wetland assessment area (WAA) should be defined as all or part of an aquatic resource at a proposed project site that is relatively homogeneous in:

(1) Character (belongs to a single HGM wetland class and is relatively homogeneous with respect to the site-specific criteria used to assess wetland condition [Smith et al. 2013]), (2) Proposed impact, or (3) Proposed mitigation, to be assessed as a single unit (Figures 20 and 21).

Figure 20. Example of a proposed mitigation project area that contains three WAAs ( $A=$ flats; $B=$ depression; $C=$ riverine) that represent three undisturbed HGM classes that must each be analyzed separately.

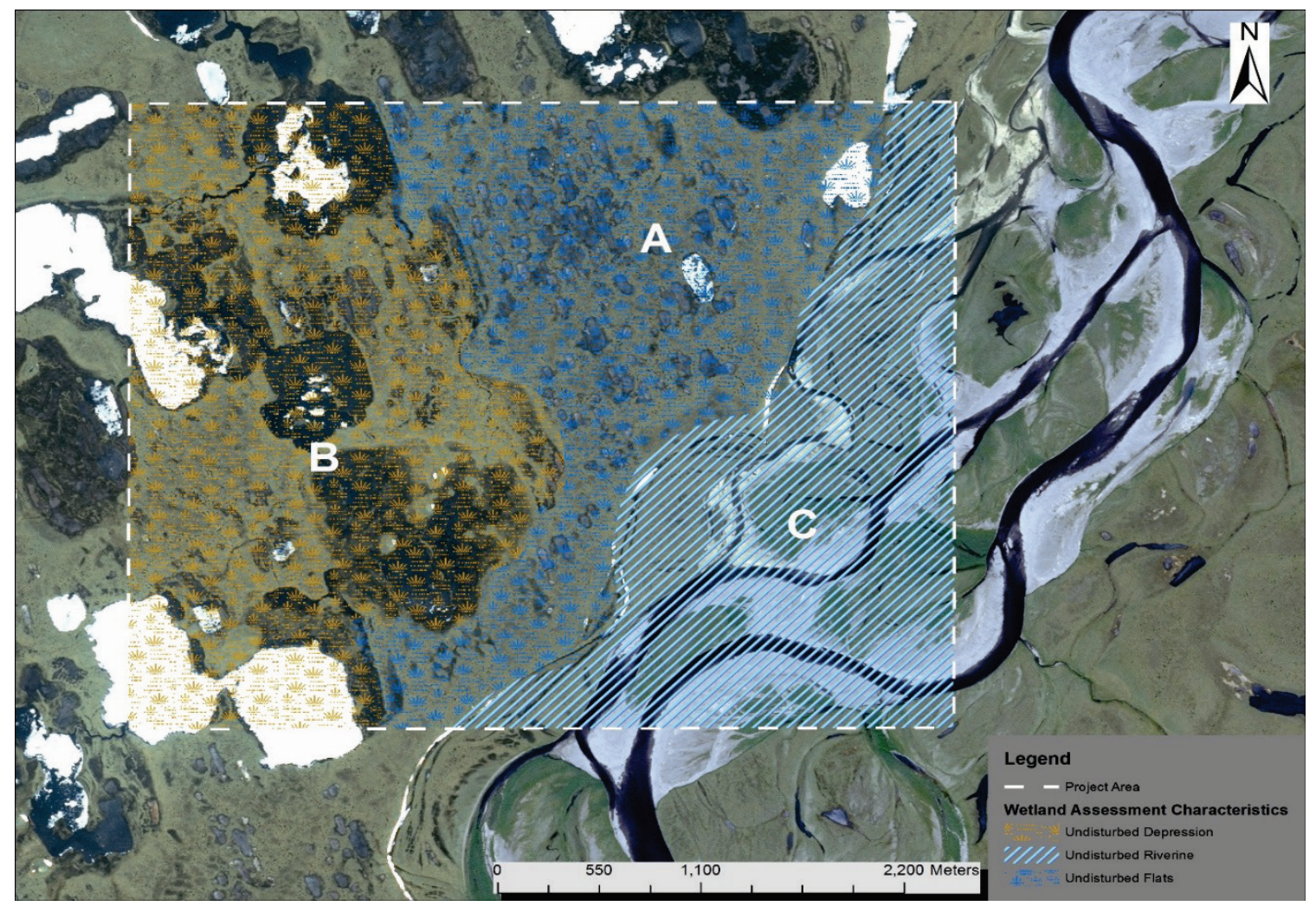


Figure 21. Example of a proposed mitigation project area containing one HGM wetland class. A portion of the wetland is undisturbed and other portions show different levels of disturbance. Note that separate wetland assessment areas are necessary in (A) the portion lacking any sign of disturbance in a flats wetland; this area will be preserved, (B) areas containing some disturbance in a flats wetland as a result of the road and fill pad; this area would undergo rehabilitation, and (C) areas filled by the road and fill pad; this area would undergo re-establishment.

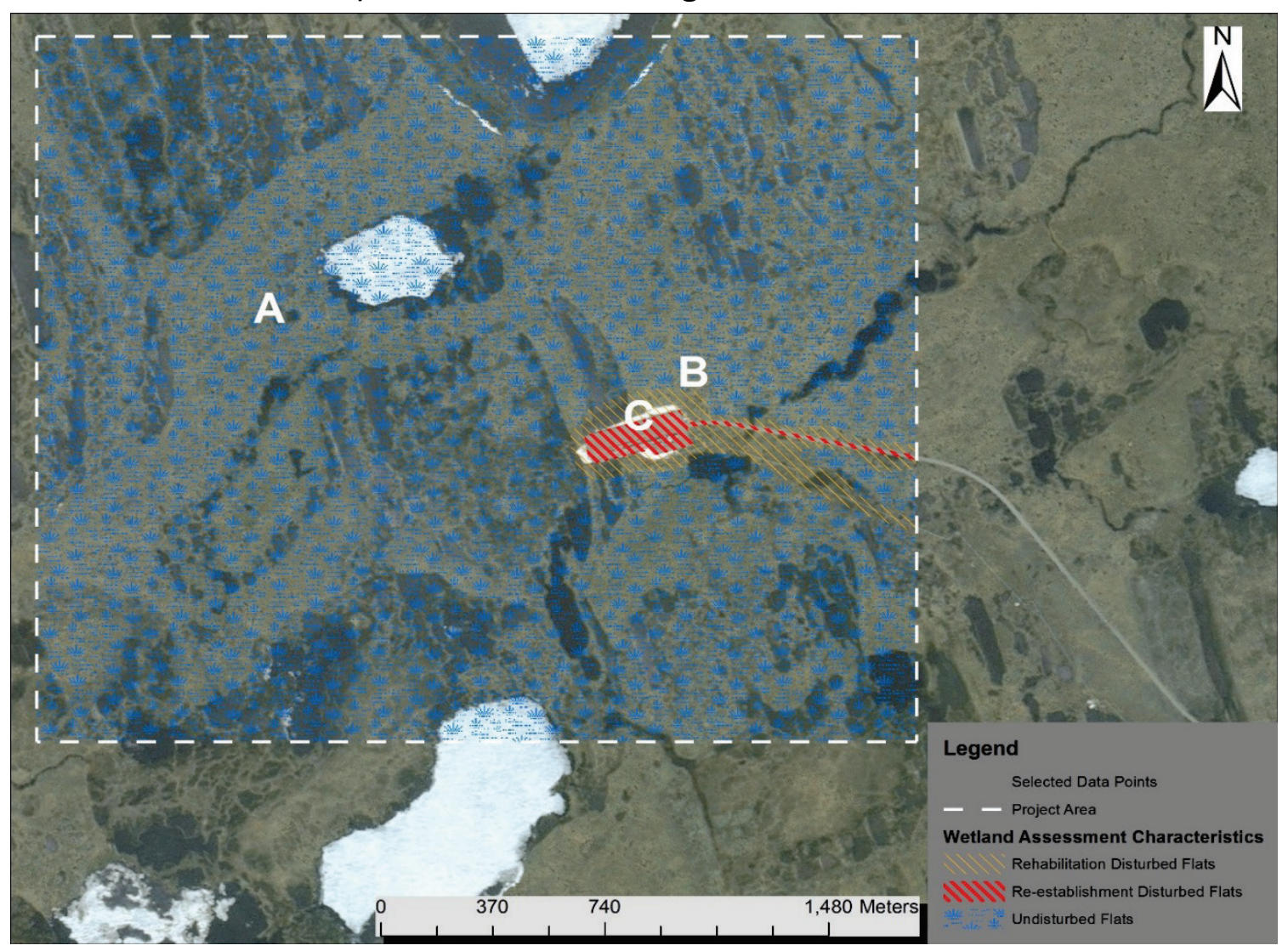

- Step 2. Select data point locations.

A minimum of one representative data point is required for each WAA (Figure 22).

- Step 3. Collect data.

Once the data have been collected for each representative data point, individual data point scores are weighted by area to determine the final wetland assessment outcome (see protocol below and scenarios in section 5.0). 
Figure 22. The dashed white line identifies the project area. There are two wetland classes present. One wetland class has both disturbed and undisturbed areas. Therefore, three wetland assessment areas are defined. A representative data point is selected for each wetland assessment area: (A) WAA

1, a disturbed flats wetland affected by infrastructure development (i.e., pad and existing road), (B) WAA 2, a riverine wetland, and (C) WAA 3, an undisturbed flats wetland.

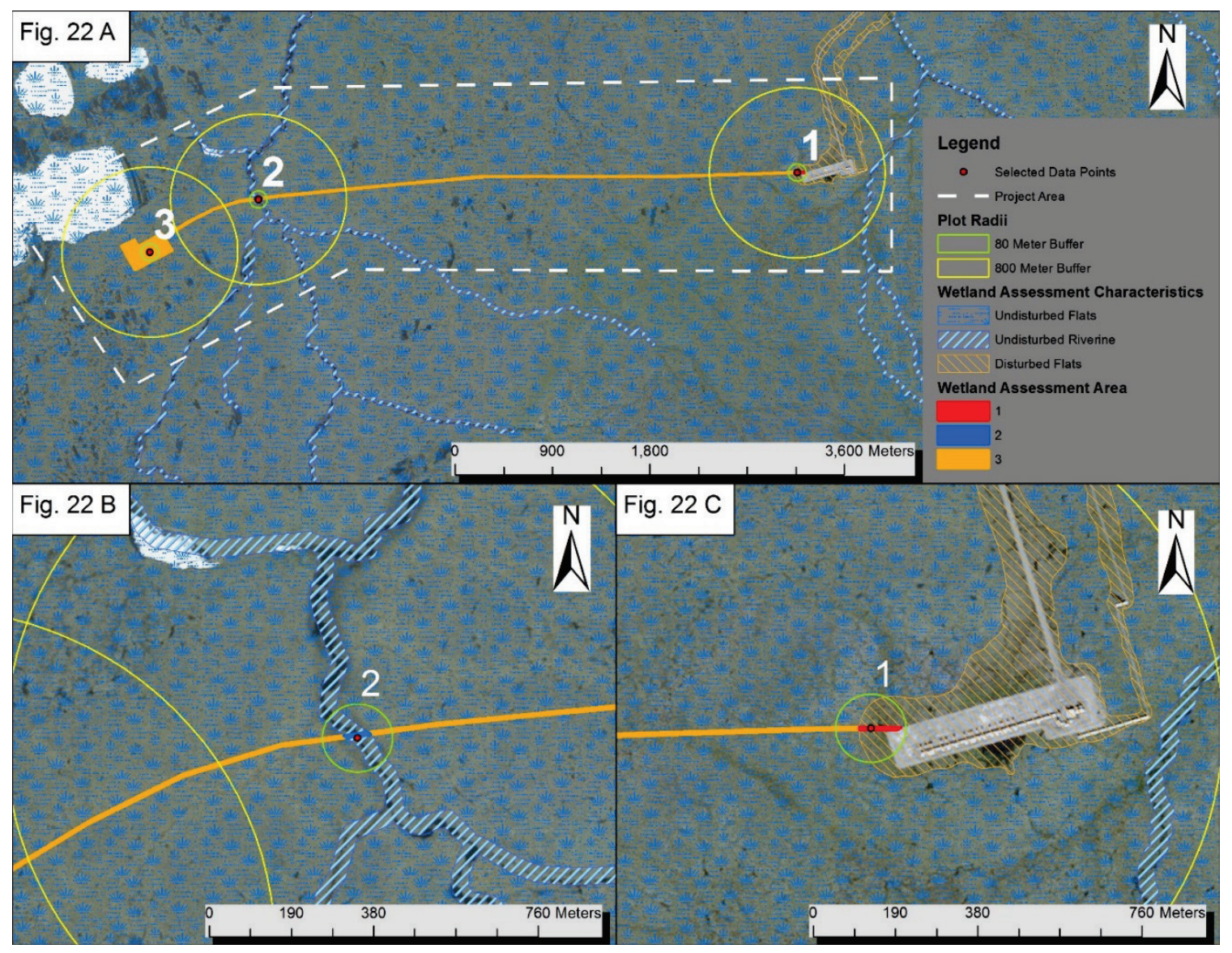

\subsection{Desktop or remote sensing variable protocol}

The collection of off-site variables occurs at two spatial scales, $80 \mathrm{~m}$ and $800 \mathrm{~m}$ radius areas. Procedures for determining each off-site variable are provided below. The variable measurements are converted to a variable subindex score using the figures provided or the wetland assessment calculator.

\subsubsection{Local landscape disturbance (VLLD)}

$V_{L L D}$ is defined as the total anthropogenic disturbance quantified as a percentage of the $80 \mathrm{~m}$ radius area. Disturbances include, but are not limited to, roads, levees, utility lines, structural features, borrow pits, pads, pipelines, and parking lots. Areas with peculiar coloration and/or textures can often be verified as disturbed by referring to historical aerial images. 
The example shown in Figure 23 includes areas occupied by a primary road, a secondary road, and a gravel pad (blue) that cumulatively occupy $23 \%$ of the plot. Use the following procedure to measure $V_{L L D}$ :

1. Centered on a representative location within the assessment area, establish an $80 \mathrm{~m}$ radius plot.

2. Determine the percentage of the area exhibiting signs of disturbance.

3. Use Figure 24 or the provided wetland assessment calculator to determine the subindex score for VLLD.

Figure 23. Percent $V_{L L D}$ assessed at the $80 \mathrm{~m}$ radius. The blue highlighted area contains a primary road, secondary road, and gravel fill pad, which occupy $23 \%$ of the plot. As a result, the total disturbed area equals $23 \%$, corresponding to a variable subindex score of 0.43 for $V_{\text {LLD. The portion }}$ highlighted in transparent orange represents an area where dust was deposited adjacent to the roadway (see discussion of $V_{D D}$ below).

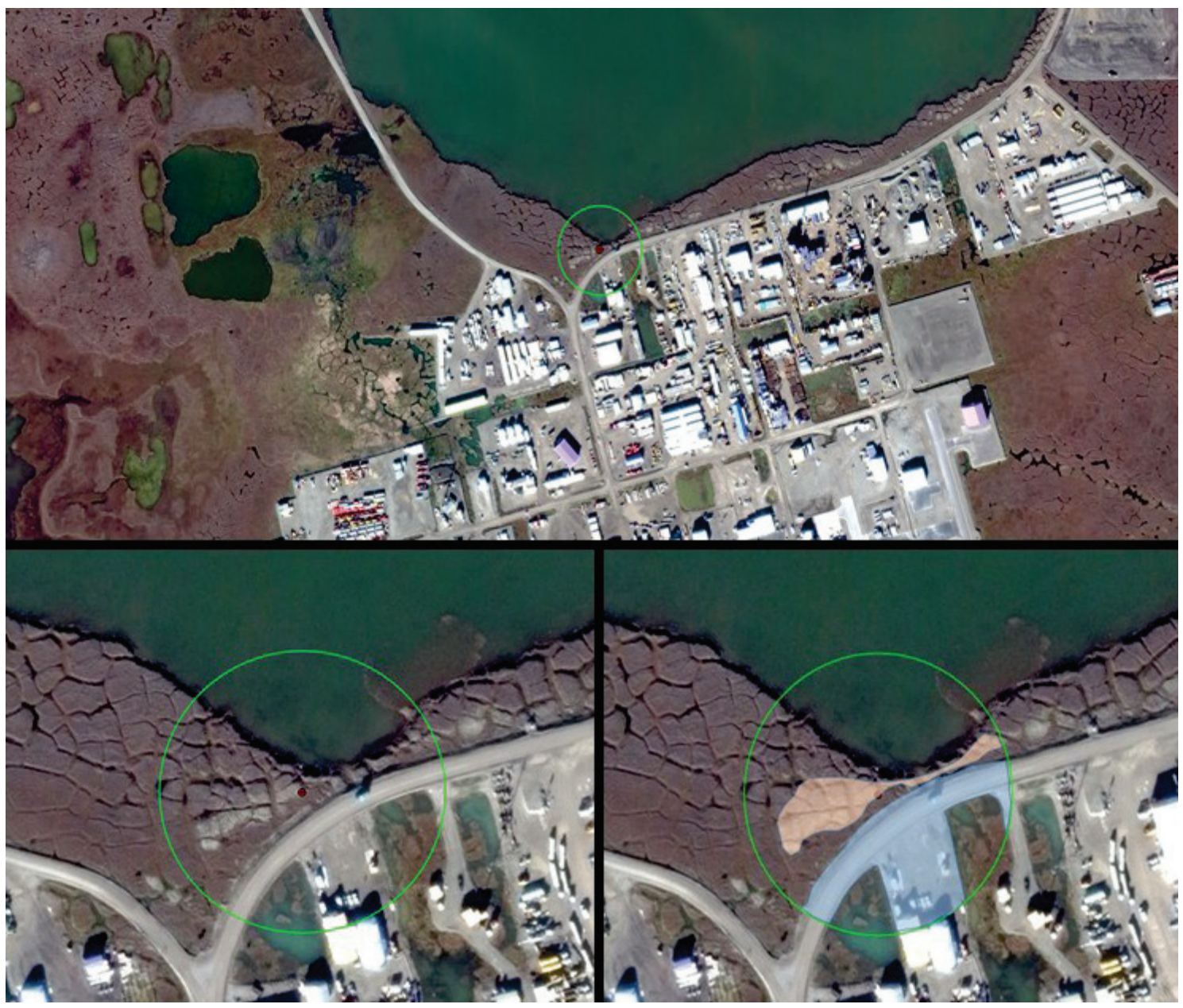


Figure 24. Association between the percentage of the $80 \mathrm{~m}$ radius plot that shows disturbance and the $V_{\text {LLD }}$ subindex score.

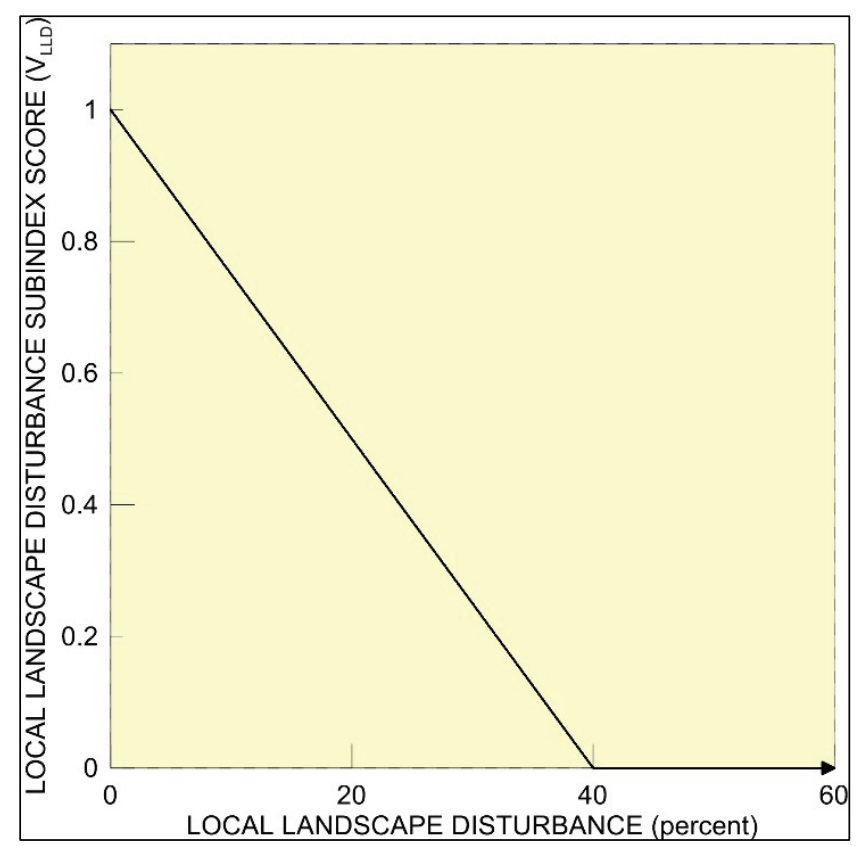

\subsubsection{Anthropogenically derived surface water ( $\left.V_{s w}\right)$}

Vsw is defined as the total amount of anthropogenically derived surface water, quantified as a percentage of an $80 \mathrm{~m}$ radius plot. This variable indicates altered hydrology, human-induced surface water ponding, or alteration of the local geomorphology by removal of the substrate and subsequent collection of surface water. These areas include water collected in excavations (e.g., borrow pits, mines), water accumulated against manmade linear features due to impaired drainage, and surface water associated with disturbances to soil stability abutting structures, pads, or fill areas. Open surface water should only be counted if it is conspicuously linked and situated in proximity to an anthropogenic activity. In Figures 25 and 26, Site A exhibits anthropogenic surface water (blue) associated with a road, pad, and utility line, occupying $15 \%$ of the plot, which corresponds to a variable subindex score of 0.1 (see Figure 27). Site B contains a borrow site (blue) adjacent to the stream and occupies approximately $35 \%$ of the plot and receives a subindex score of 0.0 (see Figure 27). In fact, all sites where the $80 \mathrm{~m}$ radius plot exhibits a $\mathrm{V}_{\mathrm{sw}}$ of $\geq 16 \%$ will score 0.0 . Use the following procedure to measure Vsw: 
1. Centered on a representative location within the assessment area, establish an $80 \mathrm{~m}$ radius plot.

2. Determine the total percentage of the plot occupied by anthropogenically derived surface water.

3. Use Figure 27 or the provided wetland assessment calculator to determine the subindex score for Vsw.

Figure 25. Percent $V_{S W}$ assessed at the $80 \mathrm{~m}$ scale, shown in transparent blue. Site $A$ exhibits anthropogenically derived open water adjacent to the road and pipeline; Site B contains open water associated with a large borrow site.

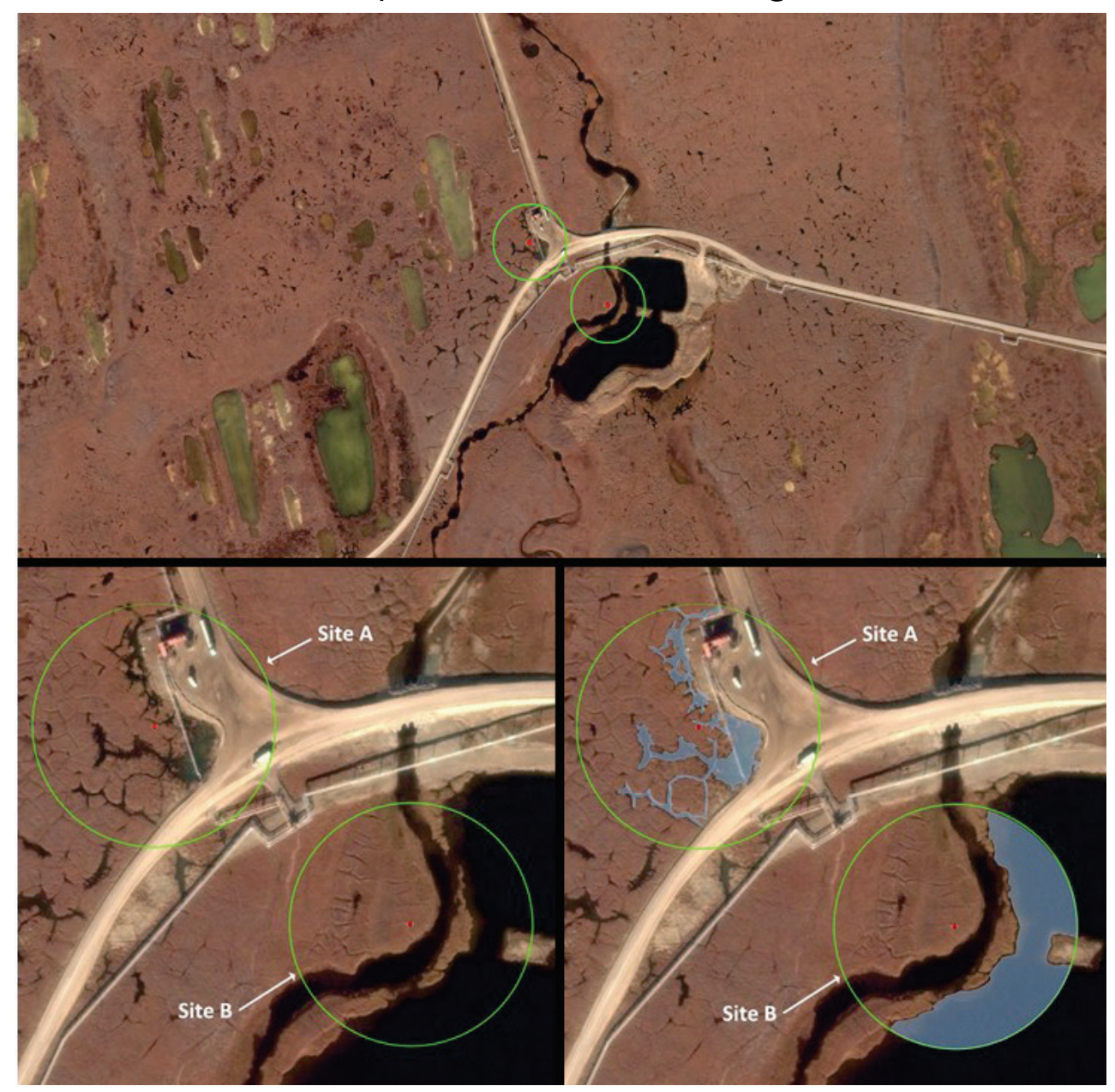


Figure 26. Ground view of Vsw adjacent to heavily disturbed area. Placement of fill material disrupted drainage, which led to an increase in surface water.

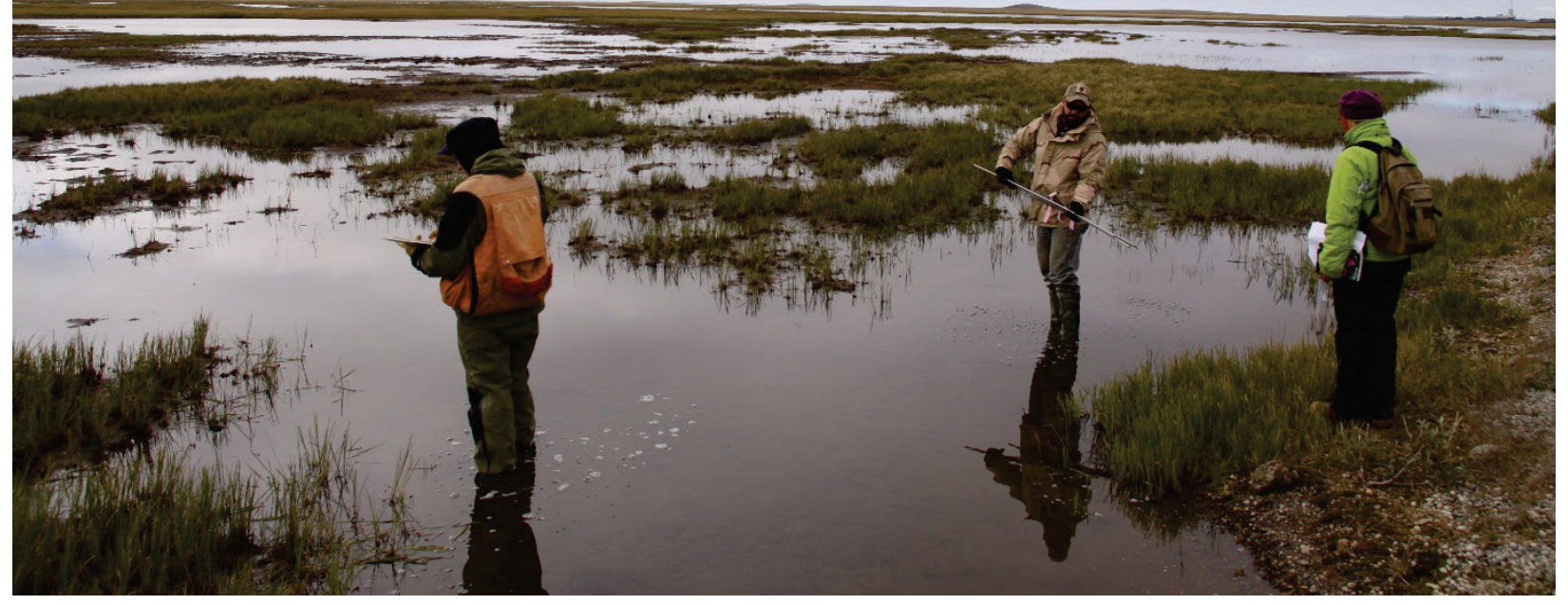

Figure 27. Association between the percentage of the $80 \mathrm{~m}$ radius area occupied by $V_{s w}$ value and the $V_{s w}$ variable subindex score.

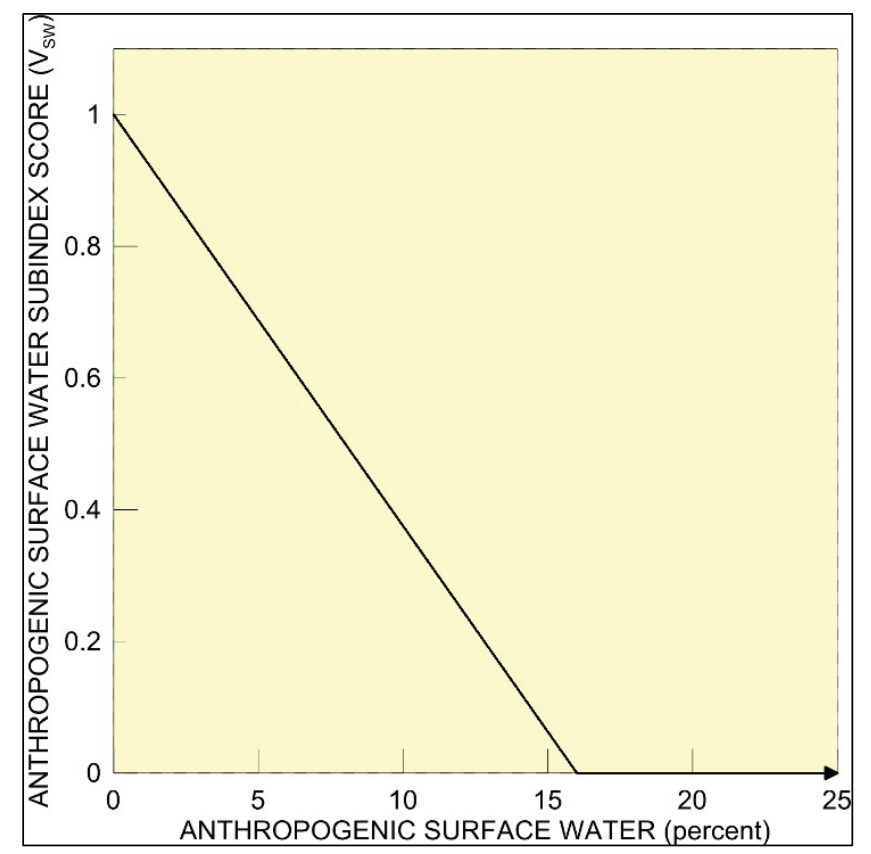




\subsubsection{Impediment to hydrology $\left(\mathrm{V}_{\mathrm{IH}}\right)$}

$\mathrm{V}_{\mathrm{IH}}$ is defined as the number of quarter segments assigned in any direction that contain hydrologic impediment, which is caused by the presence of man-made structures, excavations, or fill material. Impediments to hydrology include any activities capable of increasing or decreasing the frequency and duration of surface or near-surface water flow within the assessment area. The structure must have the capacity to impede flow. Other features occurring in a segment that do not impede flow should not be included in the determination of $\mathrm{V}_{\mathrm{IH}}$. The example shown in Figure 28 has one quarter segment impaired by a road passing through the northeast quadrant, which correspond to a variable subindex score of 0.75. Use the following procedure to measure $\mathrm{V}_{\mathrm{IH}}$ :

1. Centered on a representative location within the assessment area, establish an $80 \mathrm{~m}$ radius plot.

2. Record the number of quarter segments $(\mathrm{O}-4)$ that are impeded within the plot.

3. Use Figure 29 or the provided wetland assessment calculator to determine the variable subindex score for $\mathrm{V}_{\mathrm{IH}}$.

Figure 28. $V_{\mathrm{IH}}$ assessed at the $80 \mathrm{~m}$ scale. The shaded segment is impeded by the roadway passing through the plot.

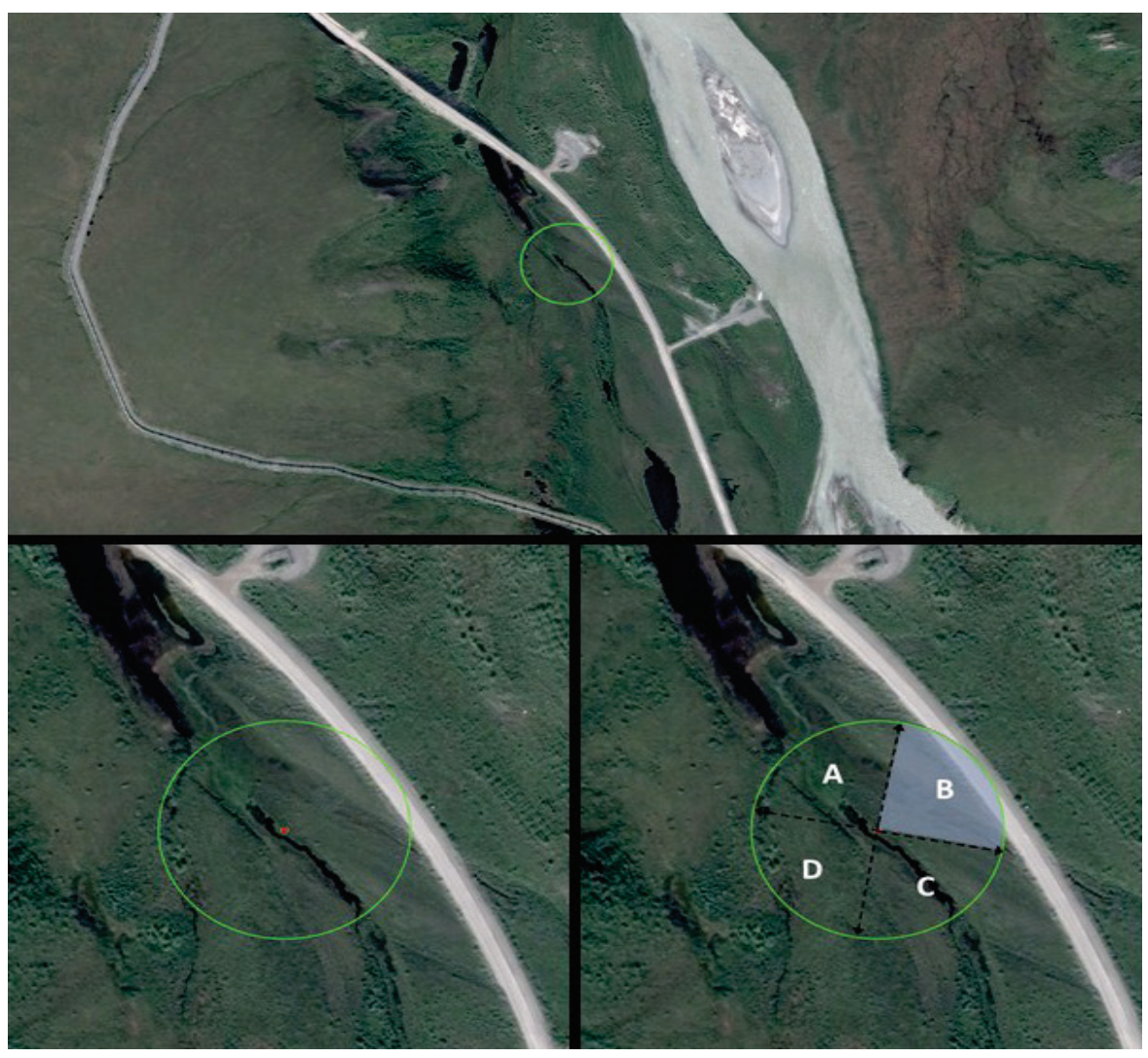


Figure 29. Association between the number of quarter segments within the $80 \mathrm{~m}$ radius area that contain an impediment to hydrology value and the $V_{\mathrm{H}}$ variable subindex score.

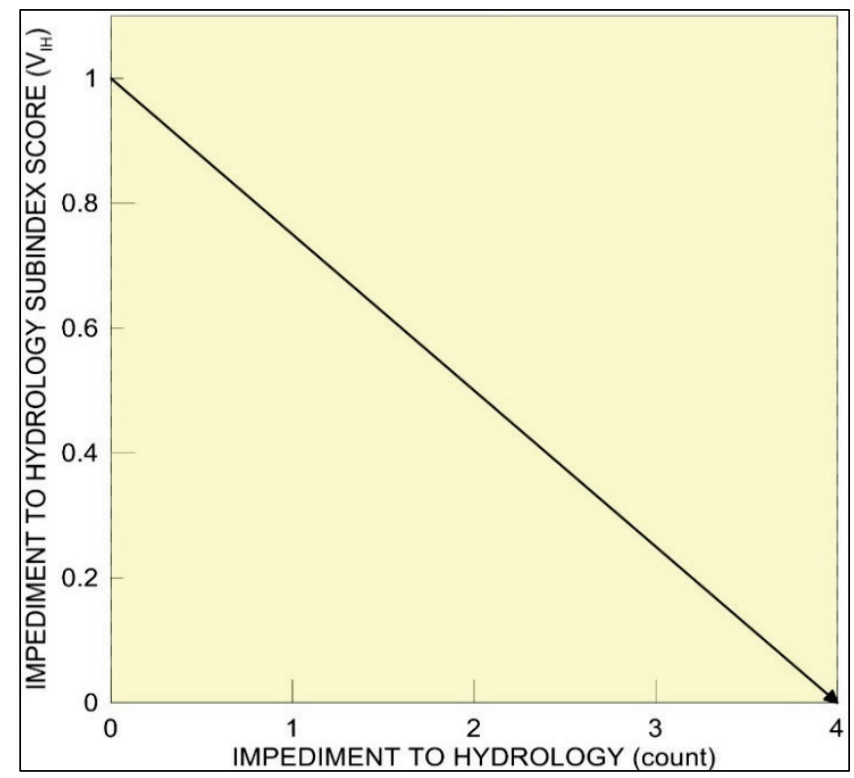

\subsubsection{Evidence of dust deposition ( $\left.\mathrm{V}_{\mathrm{DD}}\right)$}

$\mathrm{V}_{\mathrm{DD}}$ is defined as the presence of dust deposited from nearby roadways, gravel pads, parking lots, or other disturbed areas on vegetation and/or the ground surface. Dust has the capacity to impact albedo, vegetative communities, local hydrology, and the duration of snow cover (Walker and Everett 1987). Dust is often observed on one side of roadways due to predominant wind direction. Figure 30 displays an area with evidence of dust along a roadway. When present, evidence of dust deposition limits the maximum attainable assessment scores for habitat and biogeochemical cycling to 0.80 . Use the following procedure to document $\mathrm{V}_{\mathrm{DD}}$ :

1. Centered on a representative location within the assessment area, establish an $80 \mathrm{~m}$ radius plot.

2. If dust is observed within the area, indicate that on the wetland assessment calculator data form. When present, the deposition of dust limits the maximum attainable assessment subindex scores for habitat and biogeochemical cycling to 0.80 .

3. The provided wetland assessment calculator automatically accounts for the adjustment of assessment subindex scores based upon the presence or absence of $V_{D D}$. 
If the source of discoloration is in question, it should be calculated as "disturbance".

4. If the wetland assessment calculator is not being used, the user must be sure that subindex scores for habitat and biogeochemical cycling do not exceed 0.80 .

Figure 30. Evidence of dust deposition adjacent to roadways. Since this variable is assessed as presence or absence, it is not necessary to calculate the area where evidence of dust deposition occurs.

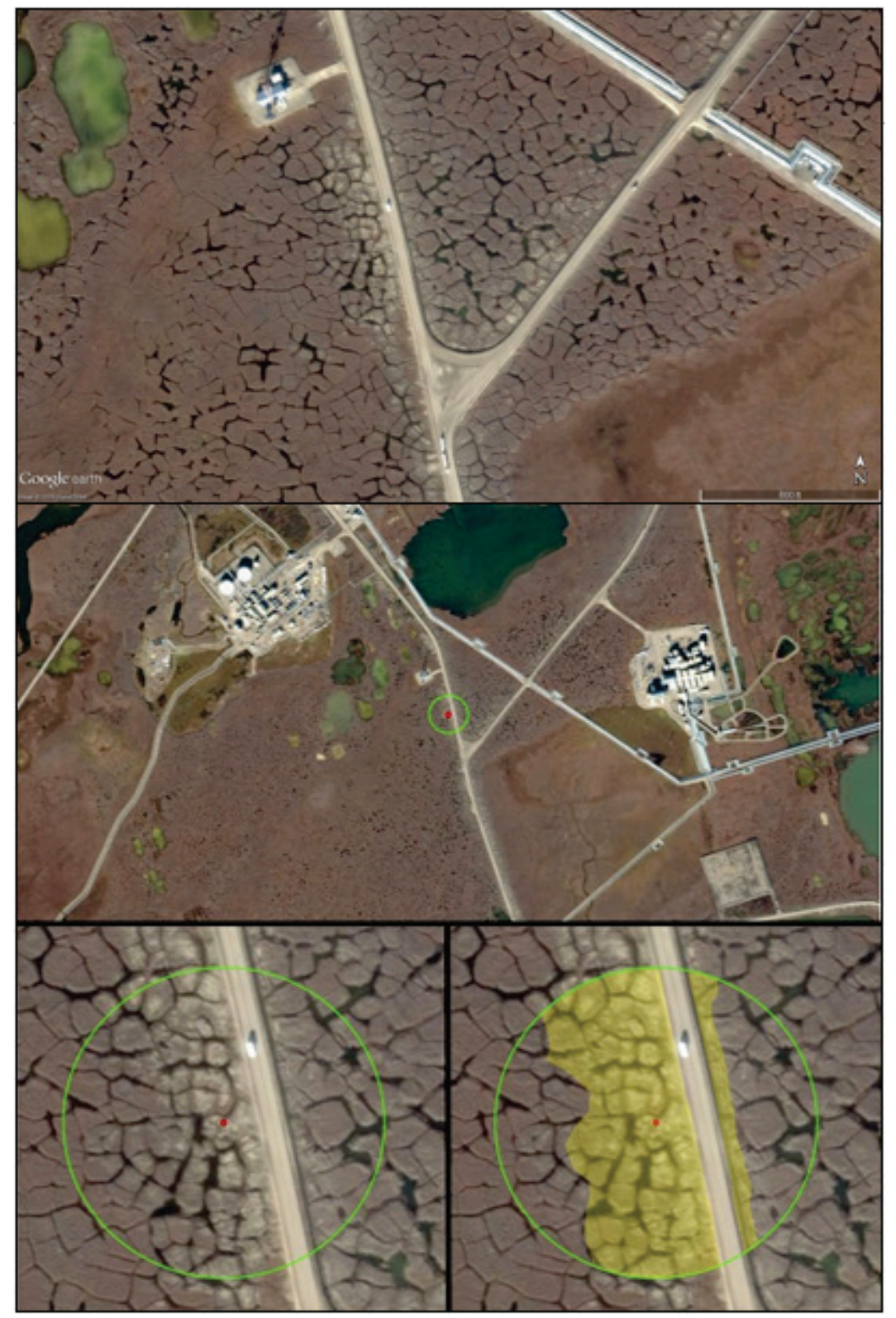




\subsubsection{Evidence of thermokarst $\left(\mathrm{V}_{\mathrm{TK}}\right)$}

Vтк is defined as the presence of thermokarst features within the $80 \mathrm{~m}$ radius area, which is often observed adjacent to roadways, gravel pads, or other infrastructure. Figure 31 displays an area with $\mathrm{V}_{\text {тк }}$ adjacent to a developed area; note the degradation of polygonal ground features and the increase in surface water compared to areas farther from the development site. When present, $\mathrm{V}_{\text {тк }}$ limits the maximum attainable assessment scores for habitat, hydrology, and biogeochemical cycling to 0.70 .

Figure 31. Example of thermokarst features located adjacent to infrastructure; note the patterns of deformed polygonal ground occurring at the edge of fill pads and roads.

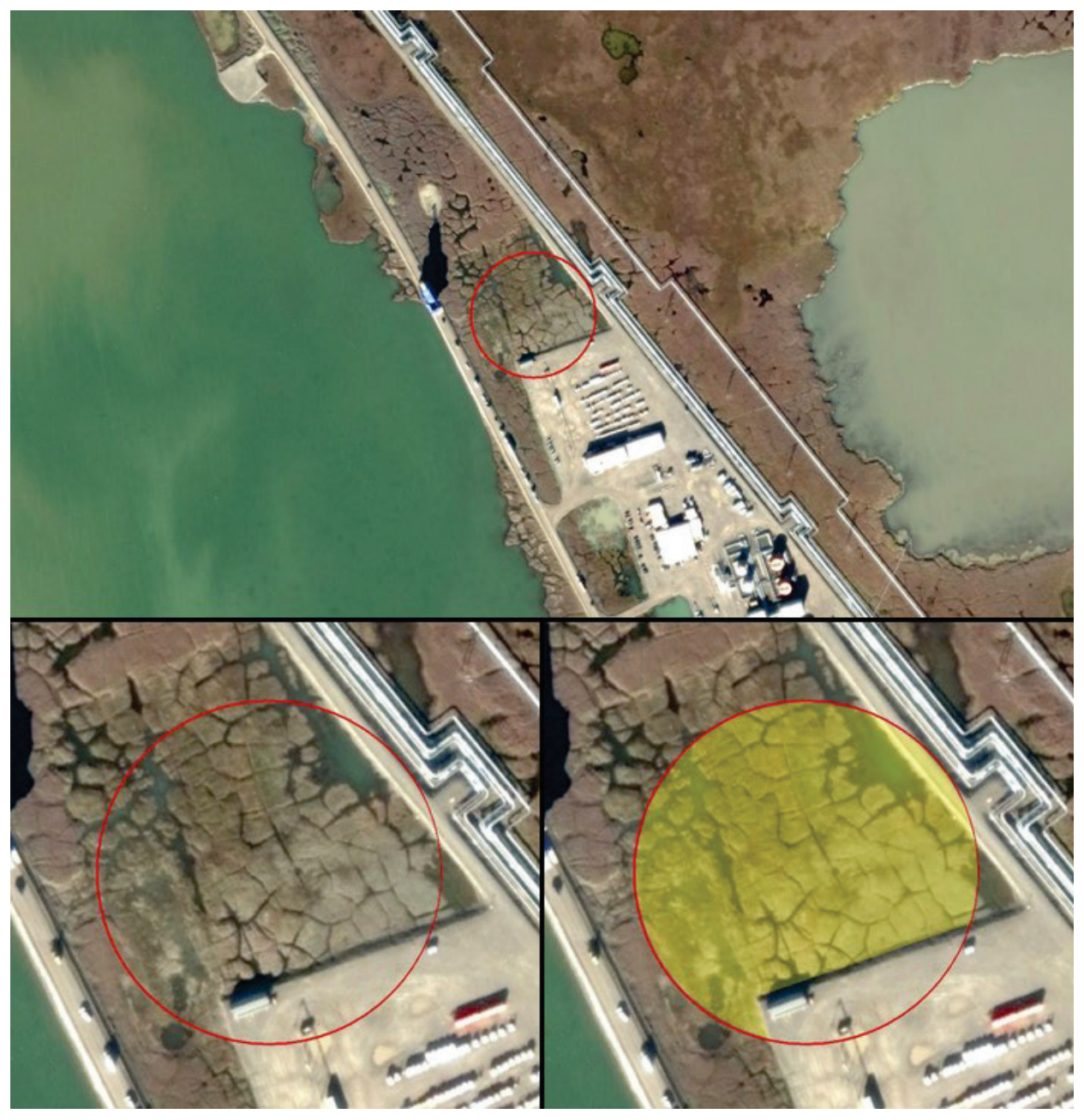


Use the following procedure to document $\mathrm{V}_{\text {тк: }}$

1. Centered on a representative location within the assessment area, establish an $80 \mathrm{~m}$ radius plot.

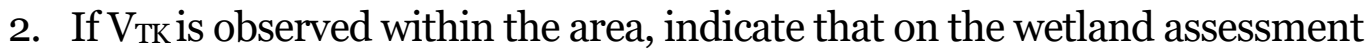
calculator data form. When present, thermokarst limits the maximum attainable assessment subindex scores for habitat, hydrology, and biogeochemical cycling to 0.70 .

3. The provided wetland assessment calculator automatically accounts for the adjustment of assessment subindex scores based upon the presence or absence of $\mathrm{V}_{\text {Tк. }}$

4. If the wetland assessment calculator is not being used, the user must be sure that subindex scores for habitat, hydrology, and biogeochemical cycling do not exceed 0.70 .

\subsubsection{Landscape disturbance (VLD)}

$\mathrm{V}_{\mathrm{LD}}$ is defined as the total anthropogenic disturbance, at the landscape scale, quantified as a percentage of an $800 \mathrm{~m}$ radius area. Disturbances include, but are not limited to, roads, levees, utility lines, structural features, borrow pits, pads, and parking lots. Potential areas of disturbance that exhibit peculiar coloration and/or textures can be identified using multiple images (e.g., different data sources, historical images, etc.). The example shown in Figure 32 includes a secondary road, borrow pit, and an area of fill deposition (blue) that occupies approximately $12 \%$ of the plot, which corresponds to a variable subindex score of 0.76 (Figure 33). Use the following procedure to measure $\mathrm{V}_{\mathrm{LD}}$ :

1. Centered on a representative location within the assessment area, establish an $800 \mathrm{~m}$ radius plot.

2. Determine the total percent of the area occupied by disturbance.

3. Use Figure 33 or the provided wetland assessment calculator to determine the variable subindex score for $\mathrm{V}_{\mathrm{LD}}$. 
Figure 32. $V_{L D}$ assessed at the $800 \mathrm{~m}$ scale, shown in transparent blue.

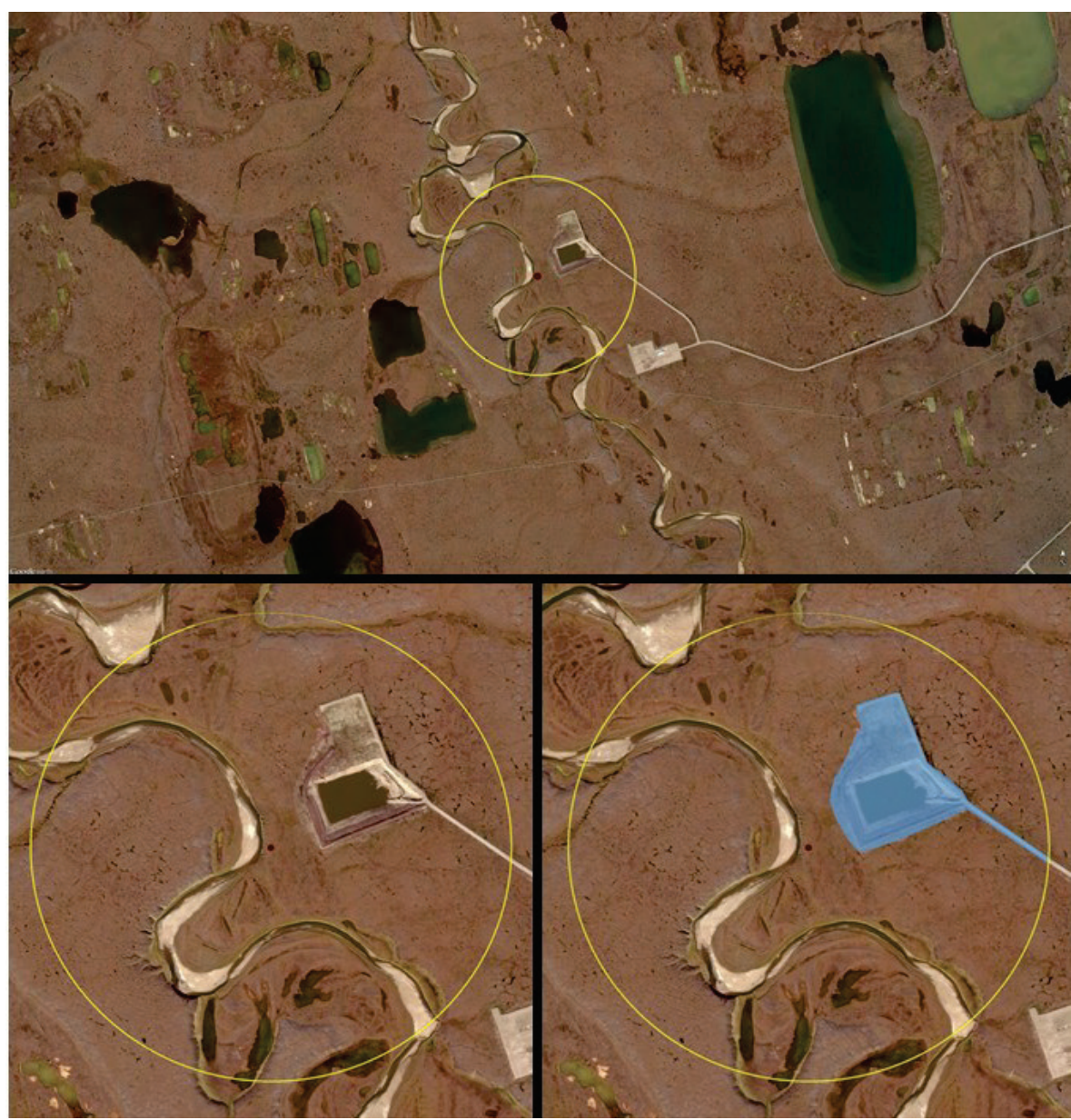

Figure 33. Association between the percentage of the $800 \mathrm{~m}$ radius area occupied by disturbance and the $V_{L D}$ variable subindex score.

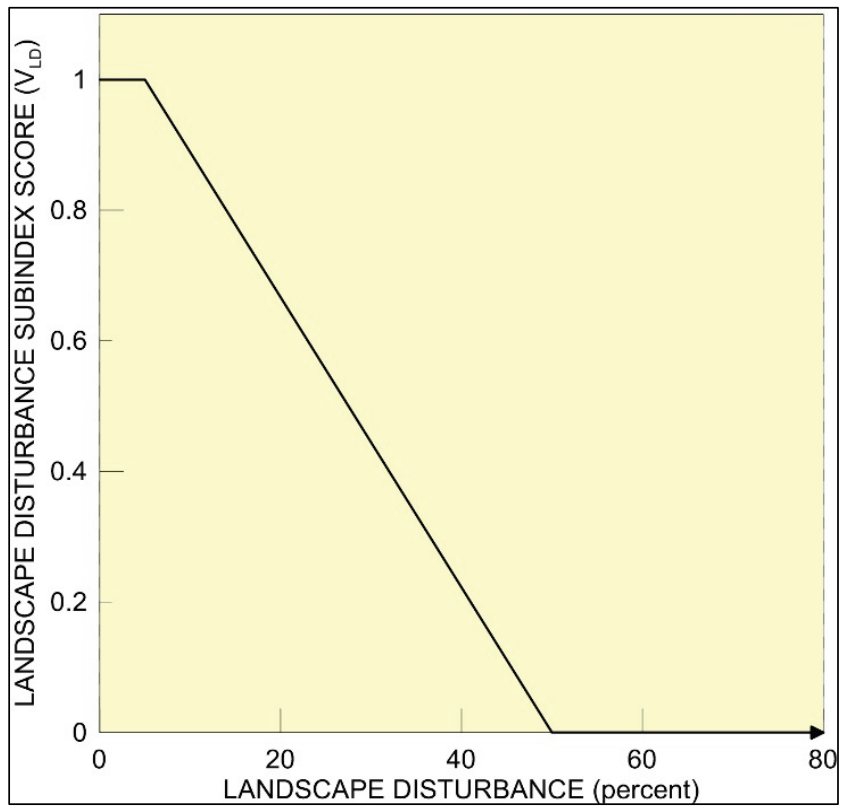




\subsubsection{Impediment to wildlife $\left(V_{I w}\right)$}

VIw is defined as the number of quarter segments, assigned in any direction, that are impaired to the free movement of wildlife by impediments such as roads, pads, pipelines, or other aboveground features. For the purpose of this assessment, natural features (e.g., lakes, rivers) are not considered an impediment. The site shown in Figure 34 has two quarter segments ( $\mathrm{C}$ and D) that are impaired by an aboveground utility line and associated structure, which correspond at a variable subindex score of 0.5 (Figure 35). Use the following procedure to measure $\mathrm{V}_{\mathrm{IW}}$ :

1. Centered on a representative location within the assessment area, establish an $800 \mathrm{~m}$ radius plot.

2. Count the number of quarter segments $(\mathrm{O}-4)$ that are impeded within the area.

3. Use Figure 35 or the provided wetland assessment calculator to determine the variable subindex score for $V_{\text {IW }}$.

Figure 34. Viw assessed at the $800 \mathrm{~m}$ scale. The shaded segments, $C$ and

D, are impeded by aboveground utilities and associated structures.

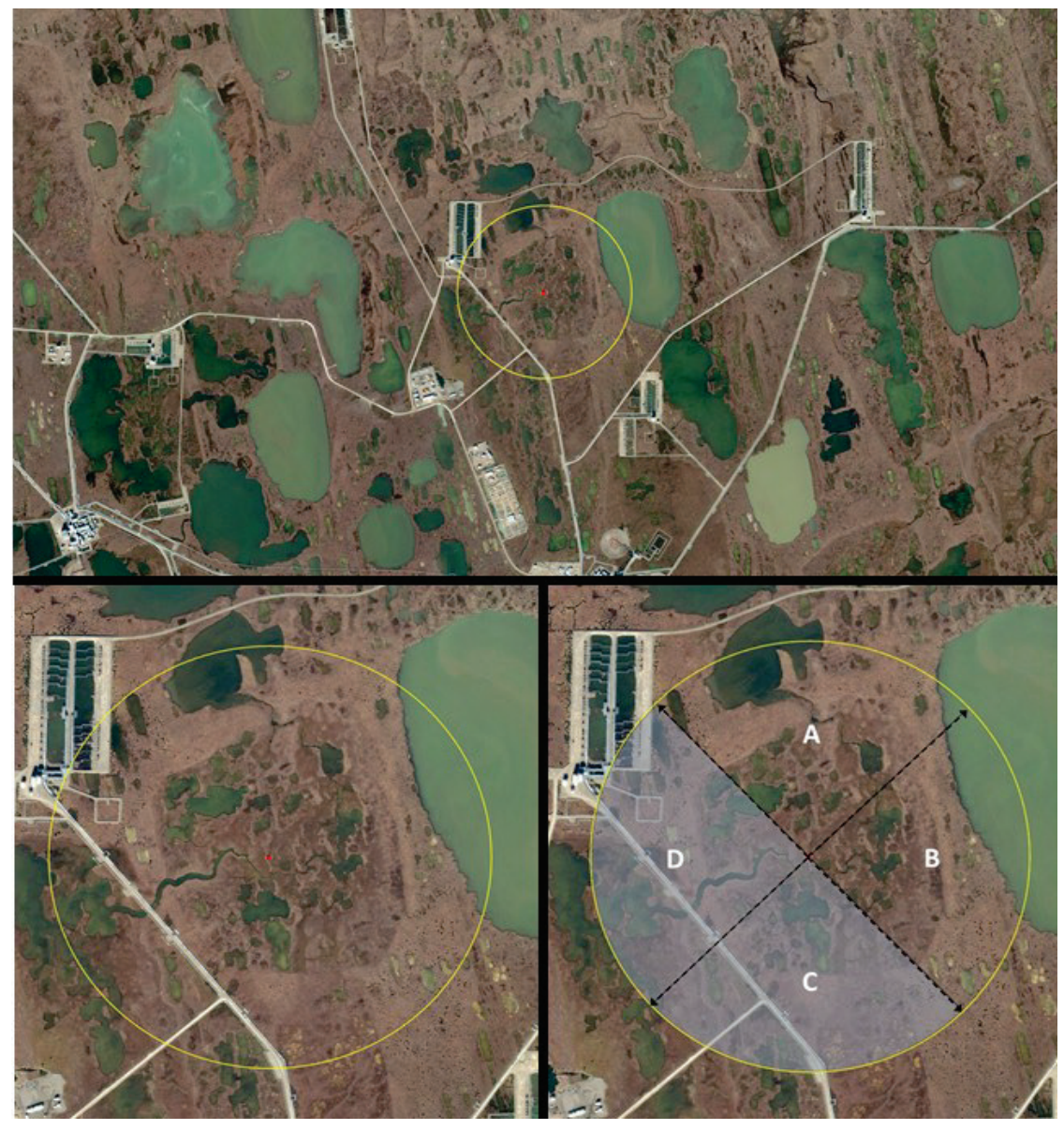


Figure 35. Association between the number of quarter segments within the $800 \mathrm{~m}$ radius area that contain an impediment to wildlife value and the $V_{I w}$ variable subindex score.

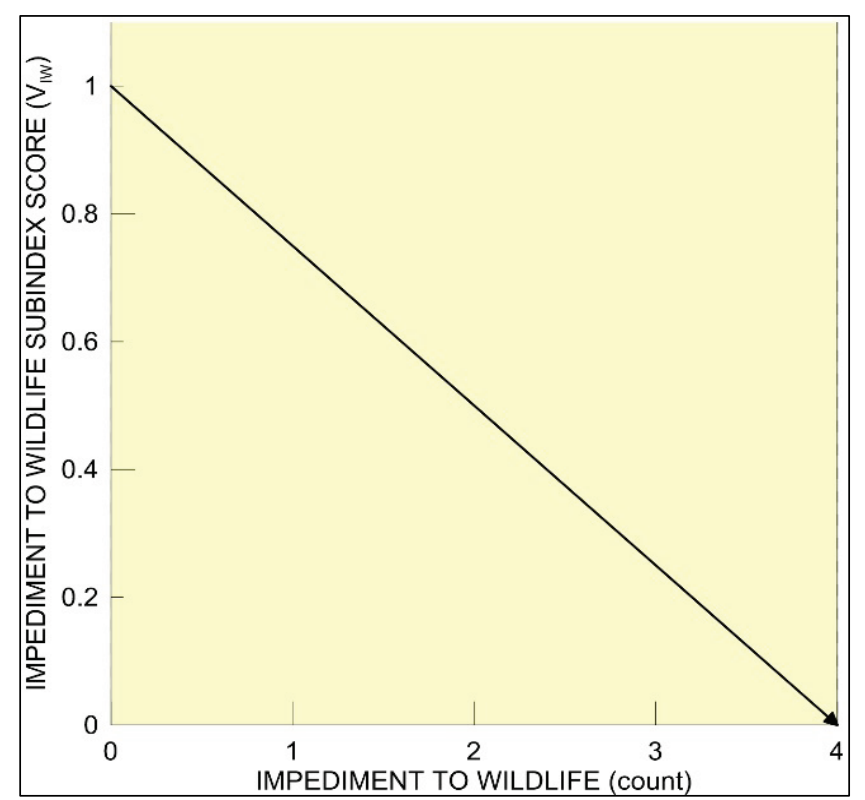

\subsubsection{Distance to roadway ( $\left.\mathrm{V}_{\mathrm{DR}}\right)$}

$V_{D R}$ is defined as the minimum distance in meters from the center of an $800 \mathrm{~m}$ radius area to a roadway of any size, class, or condition. This variable can be measured using the "ruler" tool in Google Earth, the "measure" tool in ArcMap, or a ruler with a map of a known scale. In Figure 36 , the nearest roadway is approximately $475 \mathrm{~m}$ from the assessment site, and has a subindex score of 0.95 (Figure 37). Use the following procedure to measure $V_{D R}$ :

1. Centered on a representative location within the assessment area, establish an $800 \mathrm{~m}$ radius plot.

2. Measure the minimum distance in meters, from the center of the assessment site to the nearest road, up to $800 \mathrm{~m}$.

3. Use Figure 37 or the provided wetland assessment calculator to determine the variable subindex score for $\mathrm{V}_{\mathrm{DR}}$. 
Figure $36 . V_{D R}$ from the assessment site in meters, at the $800 \mathrm{~m}$ scale.

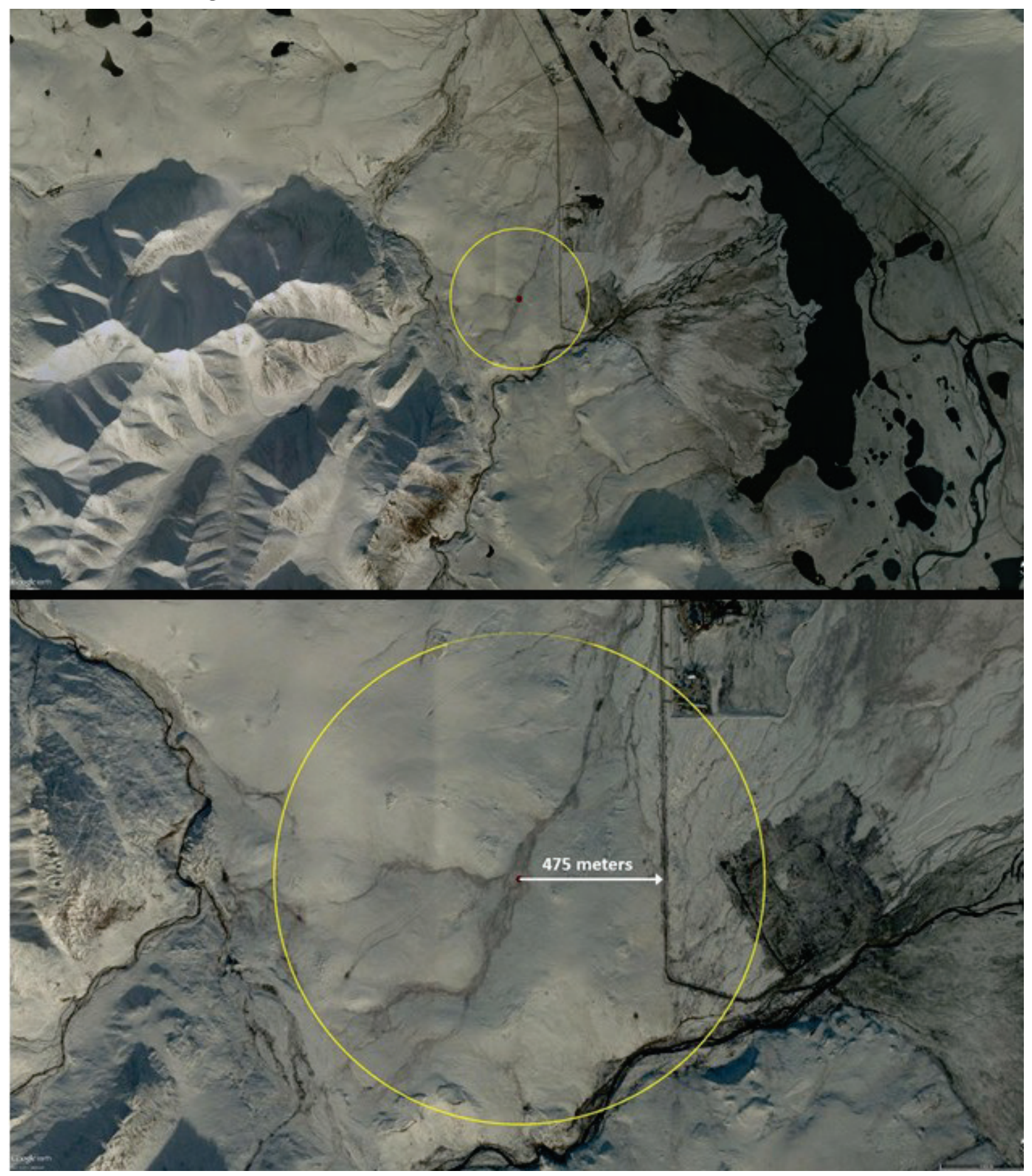


Figure 37. Association between the distance to roadway value and the $V_{D R}$ variable subindex score.

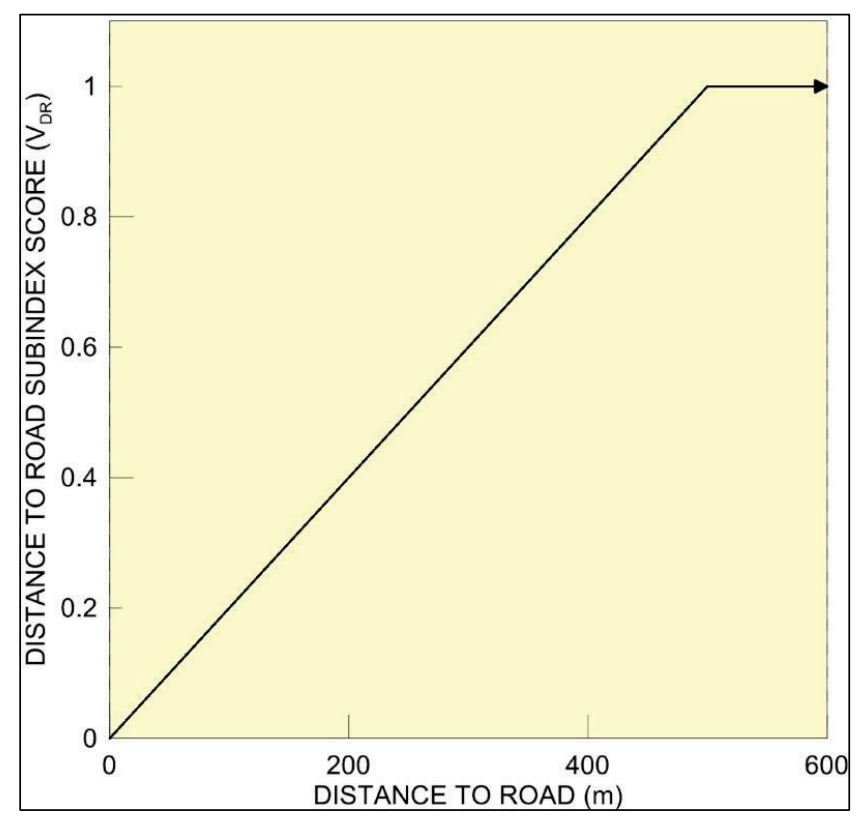

\subsection{On-site variable protocol}

The collection of on-site variables occurs within the same $80 \mathrm{~m}$ radius plot utilized to determine the off-site variables ( $\mathrm{V}_{\mathrm{LLD}}, \mathrm{V}_{\mathrm{SW}}, \mathrm{V}_{\mathrm{IH}}, \mathrm{V}_{\mathrm{TK}}$, and $\mathrm{V}_{\mathrm{DD}}$ ) above. Procedures for determining each on-site variable are provided below. The variables measurements are converted to a variable subindex score using the figures provided or the wetland assessment calculator.

\subsubsection{Microtopography $\left(\mathrm{V}_{\mathrm{MT}}\right)$}

$\mathrm{V}_{\mathrm{MT}}$ is defined as the topographic complexity of the WAA, determined at $1 \mathrm{~m}$ intervals along two $30 \mathrm{~m}$ transects. Microtopography is an important consideration in many of the wetland types that occur in the tussock tundra and areas exhibiting permafrost features (e.g., ice wedges, polygonal ground). It also serves as an indication of thermokarst and/or signs of wetland degradation. Implement the following procedure to determine $\mathrm{V}_{\mathrm{MT}}$ :

1. Establish two perpendicular $30 \mathrm{~m}$ transects, as shown in Figure 38, within each $80 \mathrm{~m}$ radius area utilized during off-site data collection.

2. Orientation of transects should be north to south and east to west, when feasible. Transects should be situated within a particular HGM class (e.g., depression, fringe) to the extent possible. As a result, transect orientations may need to be altered in order to remain within a narrow floodplain 
adjacent to small streams. If changes are necessary for plot layout (e.g., due to obstructions or open water, etc.), ensure that established sample plots are representative of the area being sampled, and note any changes to plot layout on the data form.

3. Transects can be established using a laser level and rod or ground stakes and rods, with a level string-line suspended above ground (1-1.5 $\mathrm{m}$ above ground level is often adequate). The height of each transect should be sufficient to avoid interference with vegetation (Figure 39).

4. At each $1 \mathrm{~m}$ interval along the $30 \mathrm{~m}$ transect, a measuring stick is used to record the distance, in centimeters, from the suspended string line or reference level to the ground surface (Figure 40 and 41). Thirty measurements should be recorded on the data form for the transect line.

5. Repeat the procedure for the second transect; thus sixty measurements will be recorded at each sample location.

6. To determine $\mathrm{V}_{\mathrm{MT}}$, enter the measured heights at each $1 \mathrm{~m}$ interval into the wetland assessment calculator.

7. Alternatively, $\mathrm{V}_{\mathrm{MT}}$ can be calculated manually by determining the absolute value change between each $1 \mathrm{~m}$ interval. For example, in Figure 41 the absolute difference between the first two sample points $(60 \mathrm{~cm}$ and $75 \mathrm{~cm})$ yield a value of 15 . Sum the total change in absolute values for the two transects. The Vмт variable subindex score can then be determined using Figures 42-44.

Figure 38. Layout for on-site data collection includes the location of transects $\left(\mathrm{V}_{\mathrm{MT}}\right)$ and quadrats $\left(\mathrm{V}_{\mathrm{BG}}, \mathrm{V}_{\mathrm{SR}}\right)$. Note that $\mathrm{V}_{\mathrm{LDD}}$ and $\mathrm{V}_{\mathrm{LTK}}$ should be documented anywhere within the sample area.

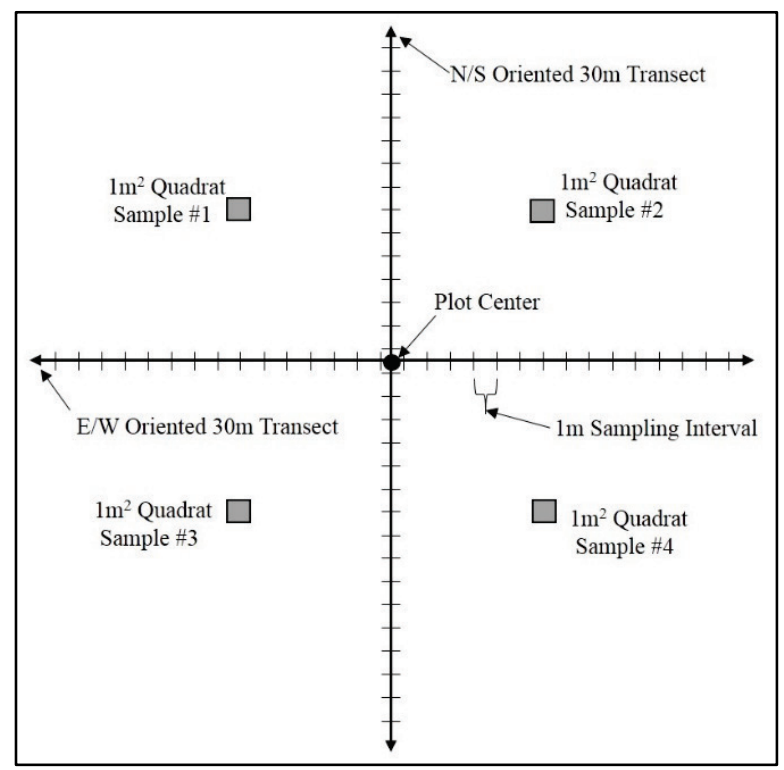


Figure 39. A transect line setup with a level, suspended line for sampling (A), and a close-up of a rod setup for a transect line end $(B)$.

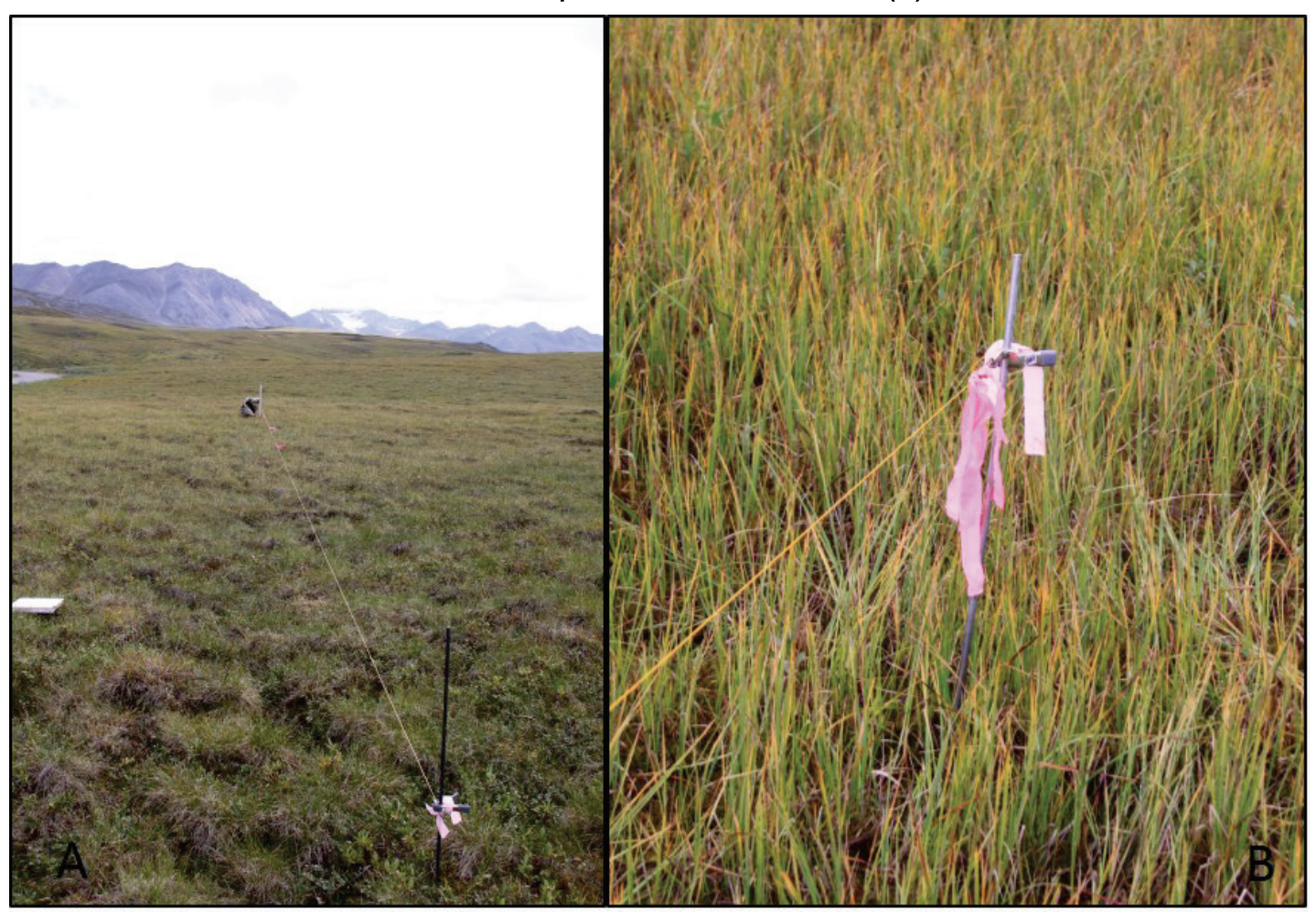

Figure 40. Measuring the distance from the reference level (i.e., level string-line) to the ground surface at each $1 \mathrm{~m}$ interval along the transect.

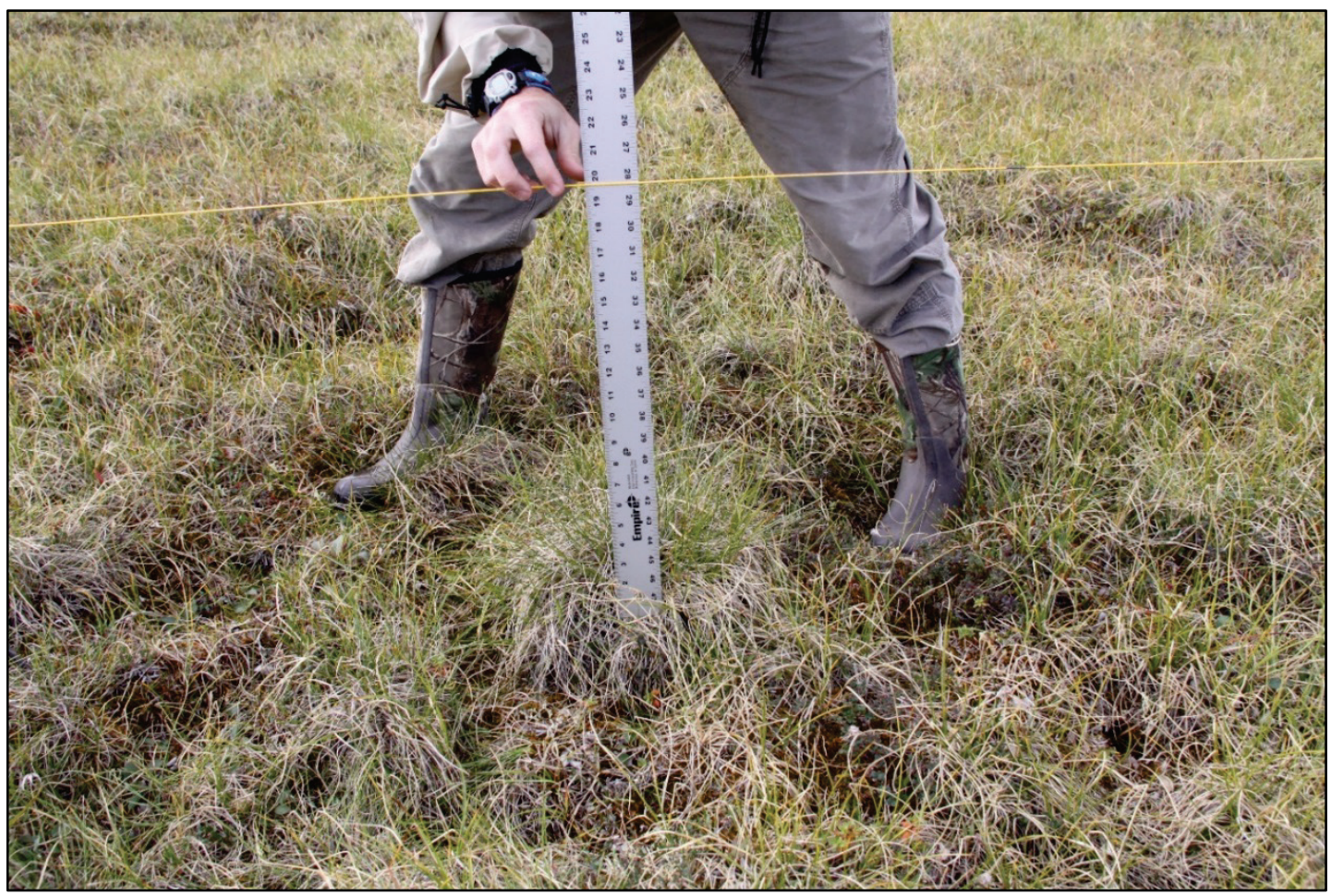


Figure 41. Partial transect line showing elevation difference measurements as measured along $1 \mathrm{~m}$ intervals.

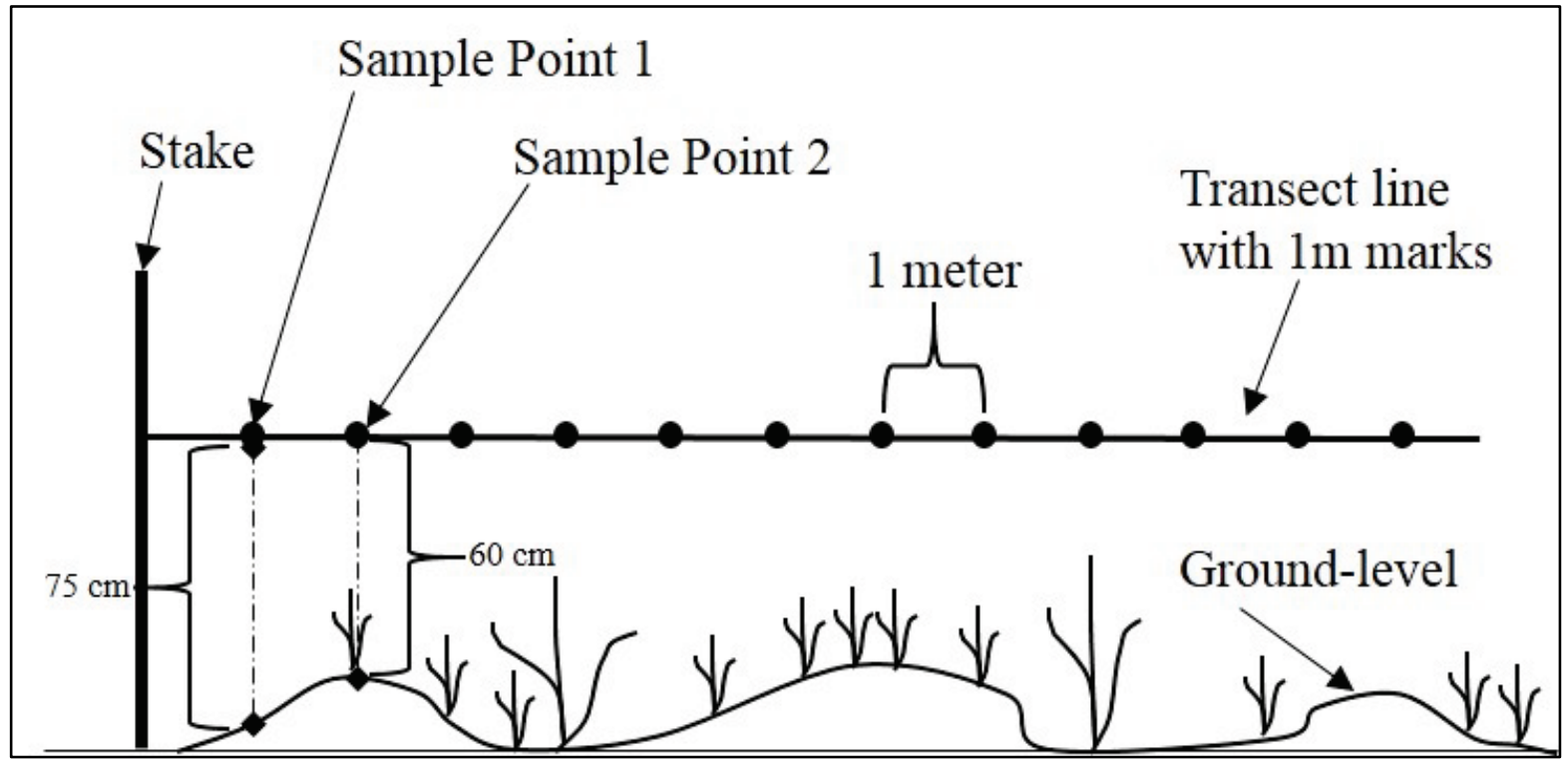

Figure 42. Association between the microtopography value and the $\mathrm{V}_{\text {MT }}$ variable subindex score for fringe and depression wetland classes.

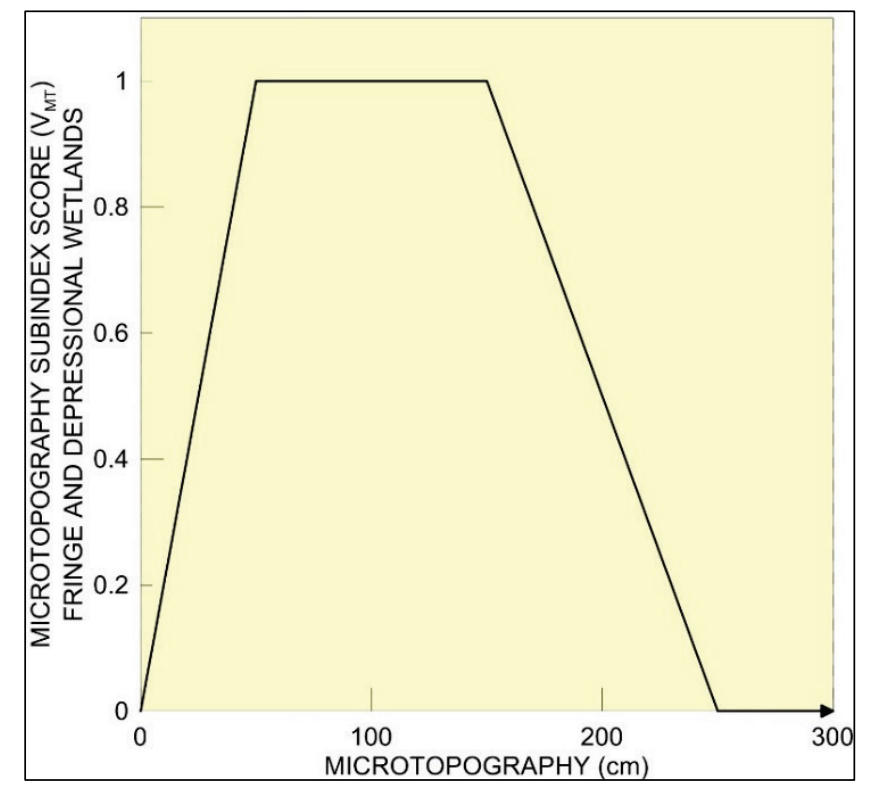


Figure 43. Association between the microtopography value and the $\mathrm{V}_{\mathrm{MT}}$ variable subindex score for riverine and flats wetland classes.

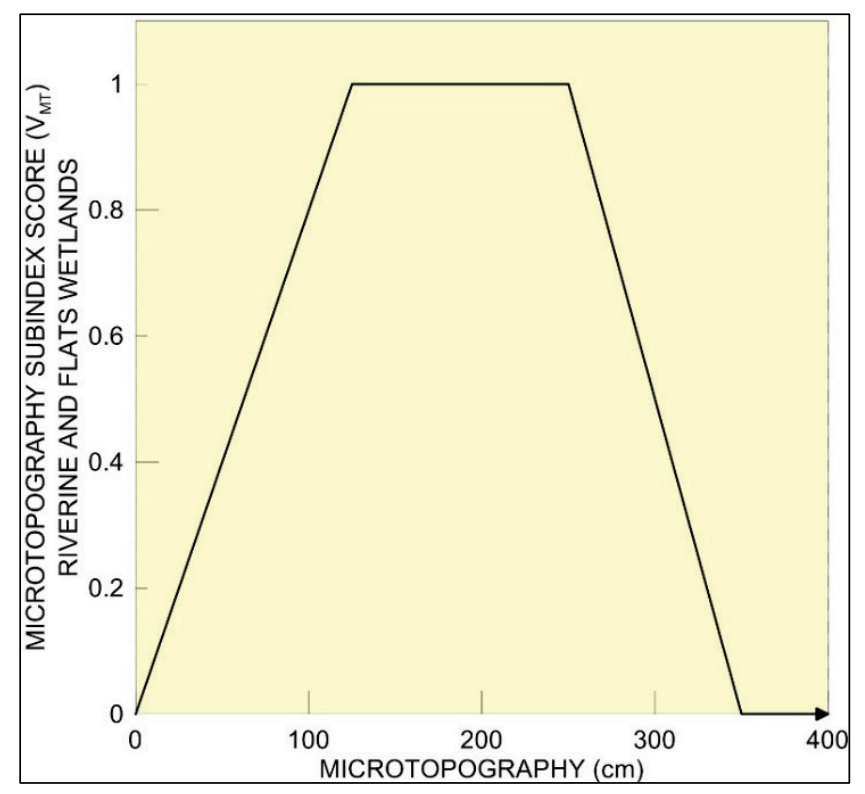

Figure 44. Association between the microtopography value and the $\mathrm{V}_{\mathrm{MT}}$ variable subindex score for slope wetlands.

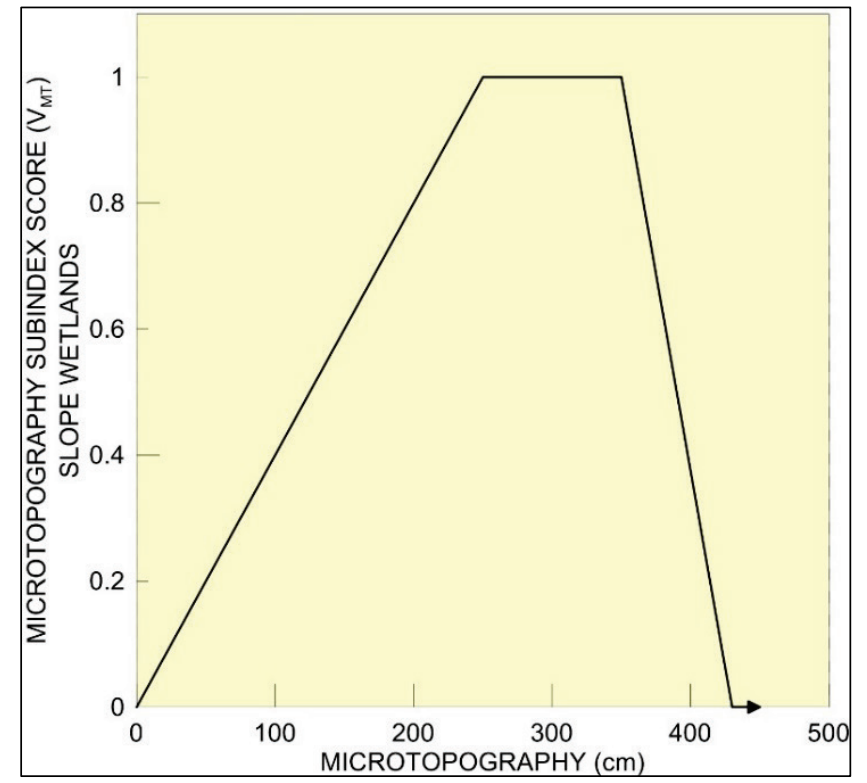

\subsubsection{Species richness (V}

$V_{\text {SR }}$ is defined as the number of vascular plant species represented within four $1 \mathrm{~m}^{2}$ quadrats. VSR provides a rapid assessment tool to evaluate species richness. To determine VSR, use the following protocol: 
1. Using the transect lines as boundaries, establish one $1 \mathrm{~m}^{2}$ quadrat within each quarter segment of the sample area as depicted in Figure 38. Selected quadrat locations should be representative of the site being assessed.

2. Within each quadrat, tally the count of species (vascular plants only; mosses, lichens or liverworts are excluded) and record on the data form.

3. To calculate $V_{S R}$, the average tally across all four quadrats are used. The calculator tool will calculate VSR, or Figures $45-46$ can be used to determine the value. For example, if average species richness within the ACP for a site was four, Figure 45 would be used to determine the $V_{\text {SR }}$ subindex score of 0.4. Some wetlands in the region display low species richness regardless of ecological conditions. As a result, wetlands located along tidal fringes and wetlands in which $>50 \%$ of the total plant cover consists of Arctophila fulva, Carex aquatilis, and/or Puccinellia sp. receive a species richness score of 1.0. The wetland assessment calculator automatically accounts for this based upon user inputs.

Figure 45. Association between the average species richness observed in four $1 \mathrm{~m}^{2}$ quadrats and the VSR variable subindex score within the ACP region.

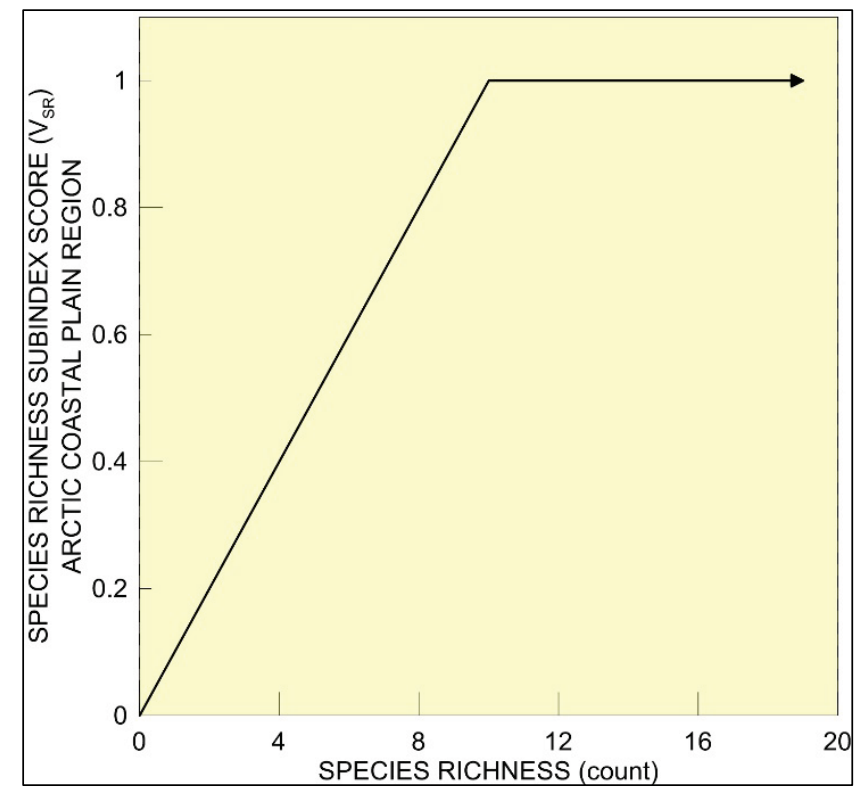


Figure 46. Association between the average species richness observed in four $1 \mathrm{~m}^{2}$ quadrats and the $V_{S R}$ variable subindex score within the foothills region.

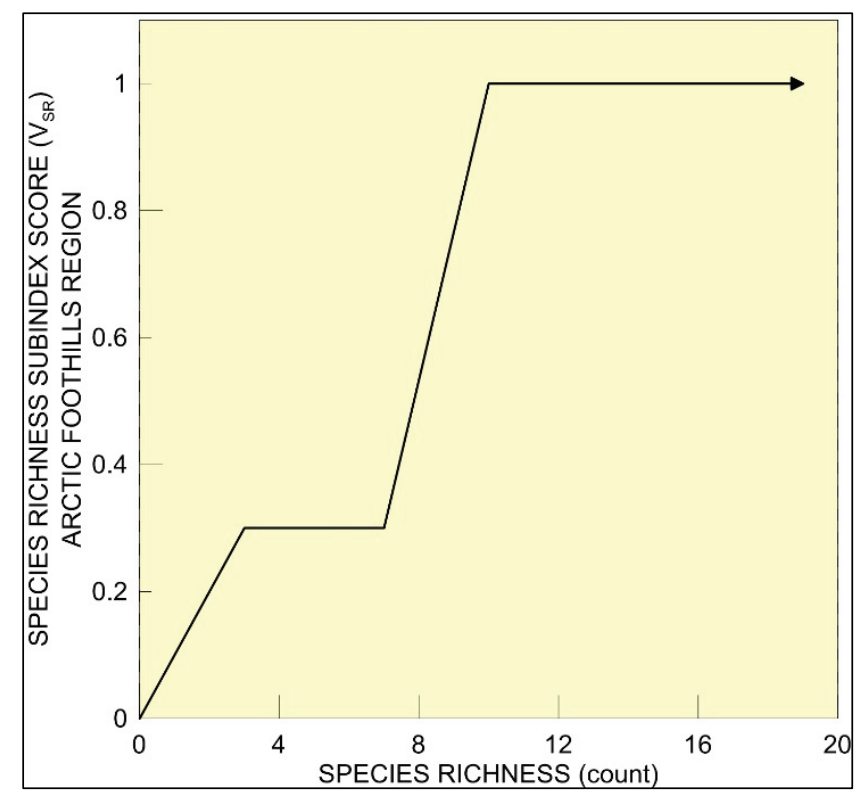

\subsubsection{Bare ground $\left(\mathrm{V}_{\mathrm{BG}}\right)$}

$\mathrm{V}_{\mathrm{BG}}$ is defined as a measure of the bare ground and expressed as areas lacking vascular or non-vascular plant cover. $\mathrm{V}_{\mathrm{BG}}$ is calculated as the average percentage of bare ground observed within four $1 \mathrm{~m}^{2}$ quadrats. This variable serves as an indirect measure of vegetation density, as areas with low vegetation density display increased levels of bare ground. $V_{B G}$ is calculated using the following protocol:

1. Using the same quadrat sample area used to determine species richness (V $\mathrm{V}_{\mathrm{SR}}$ ), estimate the percentage of bare ground to the nearest $5 \%$. Figure 47 provides examples of quadrats with varying amounts of bare ground.

2. The average percentage of bare ground across the four quadrats is used to determine $V_{\text {BG. }}$

3. Use the wetland assessment calculator in Figure 48 to determine the variable subindex score for $\mathrm{V}_{\mathrm{BG}}$. 
Figure 47. Examples of quadrat with bare ground estimates of (A) $100 \%$, (B) $90 \%$, (C) $25 \%$, and (D) $0 \%$.

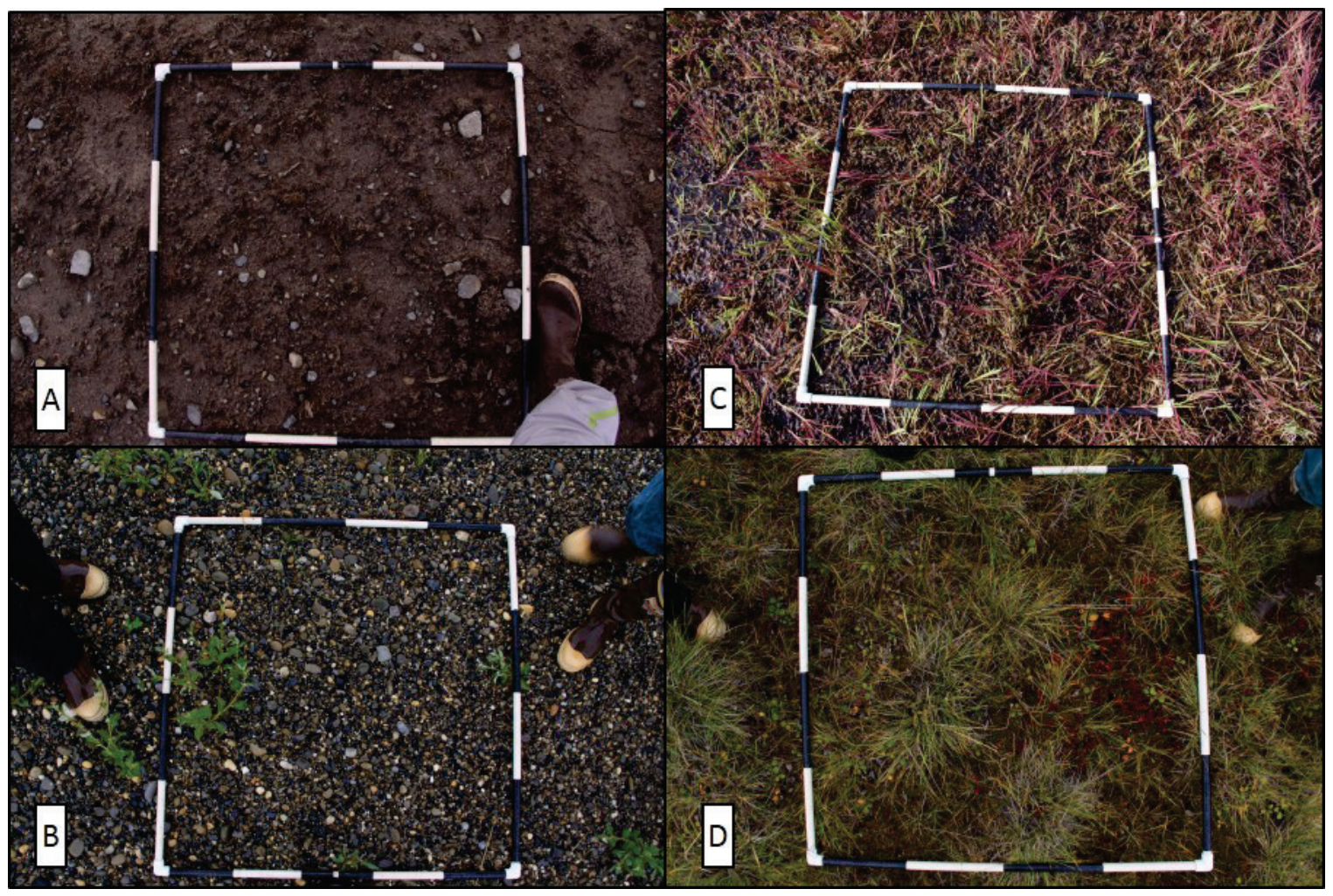

Figure 48. Association between the average percentage of bare ground observed within four $1 \mathrm{~m}^{2}$ quadrats and the $\mathrm{V}_{\mathrm{BG}}$ variable subindex score.

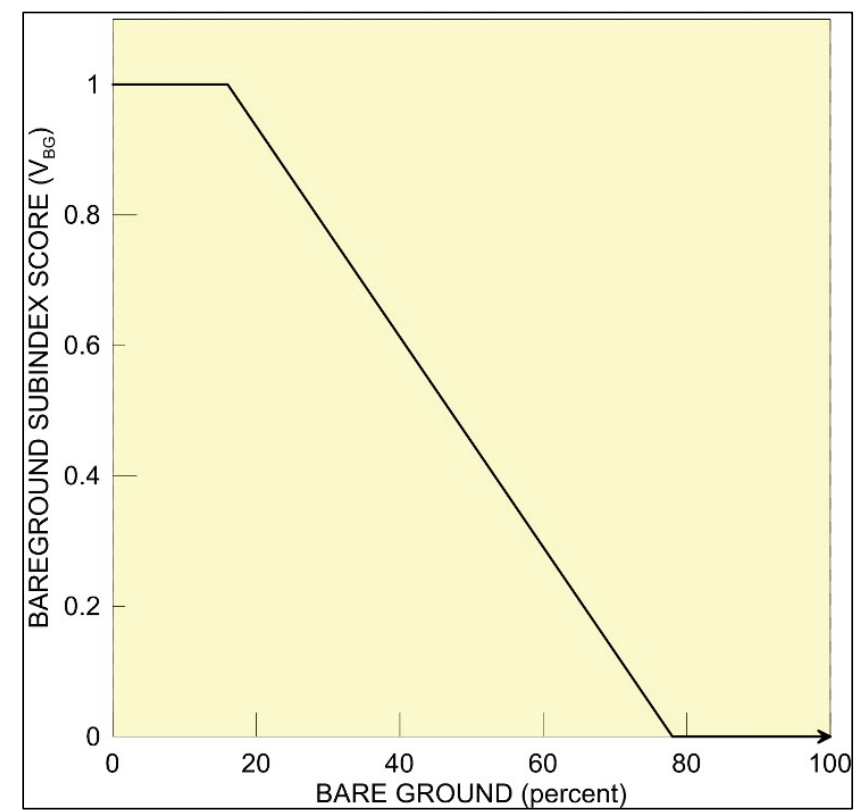




\subsubsection{Local evidence of thermokarst ( $\left.\mathrm{V}_{\mathrm{LTK}}\right)$}

If thermokarst disturbance is present on-site, the field team should record it on the data form or select "Yes" if using the calculator tool. When thermokarst occurs within the sampling area, the maximum possible score for the on-site assessment is 0.70. An example of thermokarst is depicted in Figure 49. 
Figure 49. Examples of thermokarst occurring in an area where vegetation has been removed (top), and the area adjacent to infrastructure that has formed thermokarst features (bottom).
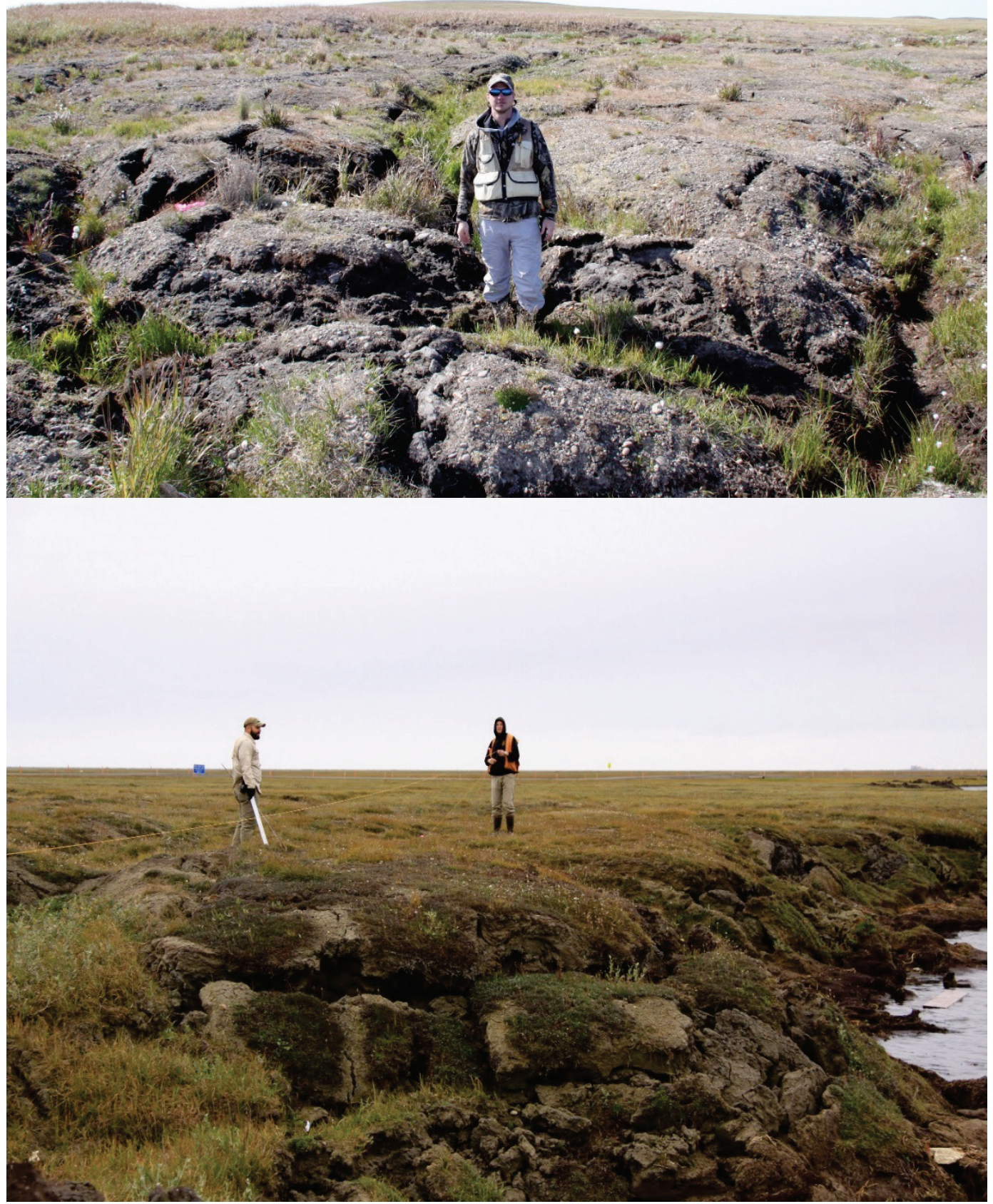


\subsubsection{Local evidence of dust disturbance (VDD)}

If dust is present on the vegetation during an on-site assessment as a result of roadway or other disturbance, the field team should record it on the data form or select "Yes" if using the calculator tool. When dust disturbance is present, the maximum possible score for the on-site assessment is 0.80. An example of dust on vegetation at a site is shown in Figure 50. 
Figure 50. Examples of dust accumulation on vegetation.

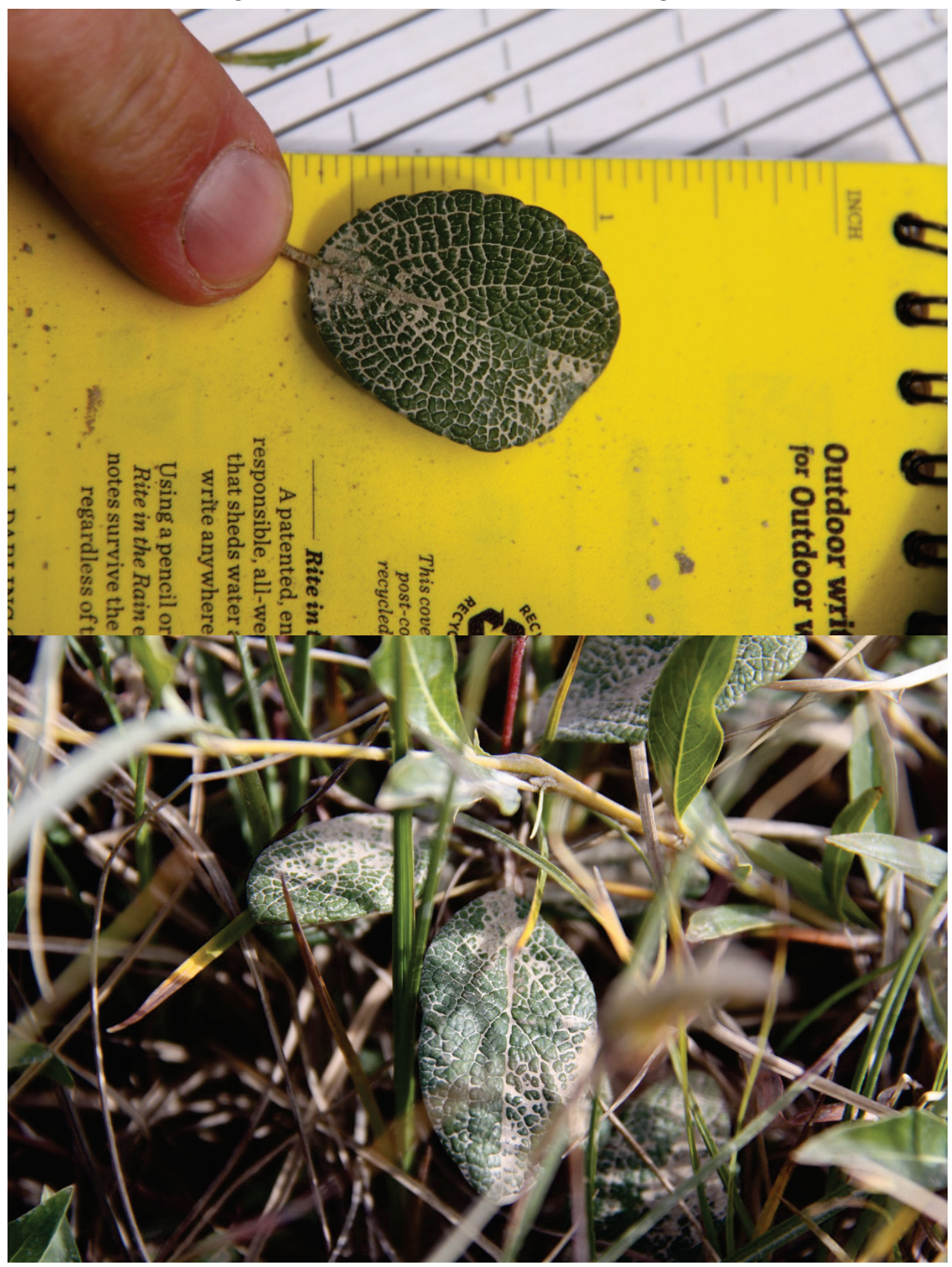




\section{Analyze the Data}

Analyzing field data can be done manually or automatically using the three-step process outlined below.

1. The first step in analyzing the field data is to transform the field measure of each assessment variable into a variable subindex score on a scale of 0 to 1.o by using the assessment calculator tool or the figures provided above.

2. The second step is to insert the variable subindices into the assessment equations (Section 2.0) and calculate the assessment scores for hydrology, biogeochemical cycling, habitat, and the on-site modifier (if used):

a. Habitat assessment score $=\left[\mathrm{MIN}\left(\mathrm{V}_{\mathrm{IW}}, \mathrm{V}_{\mathrm{DR}}\right)+\left(\left(\mathrm{V}_{\mathrm{LD}}+\mathrm{V}_{\mathrm{LLD}}\right) / 2\right)\right] / 2$

b. Hydrology assessment score $=\left[\left(\left(V_{I H}+V_{S W}\right) / 2\right)+\left(\left(V_{L D}+V_{L L D}\right) / 2\right)\right]^{1 / 2}$

c. Biogeochemical cycling assessment score $=\mathrm{MIN}\left(\mathrm{V}_{\mathrm{LD}}, \mathrm{V}_{\mathrm{LLD}}\right)$

d. On-site assessment score modifier $=\left(\mathrm{V}_{\mathrm{SR}}+\mathrm{V}_{\mathrm{BG}}+\mathrm{V}_{\mathrm{MT}}\right) / 3$

3. These assessment scores can then be incorporated into the Alaska District's Credit Debit Methodology (CDM) in order to calculate the credits generated by a mitigation project or the debits incurred by a proposed impact. Examples of how to collect, analyze, and interpret the assessment data are provided in the scenarios in Section 5.0 below.

\subsection{Apply assessment results}

Once the assessment and analysis phases are complete, the results can be used to compare the WAA at different points in time (e.g., pre- and postproject implementation) or in different WAAs at the same point in time (e.g., comparing project alternatives). To evaluate project-related impacts, at least two assessments will generally be needed. The first determines the assessment score of the WAA in its pre-project state. The second determines the assessment score in a post-project state based on proposed project plans and the anticipated changes to each of the variables. The difference between pre-project and post-project assessment scores represents the potential loss of ecological function due to the project. If the project results in conversion of land from jurisdictional wetlands to uplands, the post-project assessment score will always be 0 .

Similarly, in a scenario where establishment, restoration, or enhancement is to be conducted, the difference between the current and future status of 
a wetland, represents the potential gain in functional capacity as a result of the mitigation activities. For preservation activities, the potential gain in functional capacity is reflected in the difference between the anticipated assessment score if the project site was preserved (pre-) and the anticipated assessment score if the project site was not preserved (post). However, adjustments for temporal loss and the likelihood of success should be considered. The CDM provides a method to account for these considerations starting with the functional capacity indices described in this guidebook. 


\section{Scenarios of Proposed Activities}

The following section provides scenarios intended to demonstrate application of the wetland assessment and aid users regarding site selection, data interpretation, analysis and application of assessment results. The first scenario examines three alternatives for additional infrastructure installation to an area. The second scenario demonstrates an approach to assessing a linear road expansion project. A third scenario provides an example of how pre- and post-project assessment scores for a proposed preservation-only mitigation project can be evaluated.

\subsection{Scenario 1 - Alternatives analysis}

The following is an example scenario that demonstrates the evaluation of off-site and on-site variables utilizing the methodology described in this guidebook.

Company XYZ proposed to construct a new well-pad north of an existing facility. The company developed three alternatives (Figures 51 and 52) including: (1) a 6 ha ( $\sim 15$ acre) pad with a 2,816 m long, $6 \mathrm{~m}$ wide, access road (blue) in a riverine wetland; (2) a 6 ha ( $\sim 15$ acre) pad with a $1,126 \mathrm{~m}$ long, $6 \mathrm{~m}$ wide access road (magenta) in a depression wetland; and (3) an 8 ha ( 20 acre) pad expansion (orange) in a depression wetland. Each of the alternatives is evaluated using a separate WAA within the project area.

\subsubsection{Desktop (Off-site) evaluation of WAA1}

WAA1 is located in a riverine wetland. At the $80 \mathrm{~m}$ scale (Figure 53), the percent local landscape disturbance (VLLD), percent anthropogenically derived surface water ( $\mathrm{Vsw})$, impediment to hydrology $\left(\mathrm{V}_{\mathrm{IH}}\right)$, evidence of dust $\left(\mathrm{V}_{\mathrm{DD}}\right)$, and evidence of thermokarst $\left(\mathrm{V}_{\mathrm{TK}}\right)$ are determined. WAA1 contains $0 \% \mathrm{~V}_{\mathrm{LLD}}$, $0 \% \mathrm{~V}_{\mathrm{SW}}$, o impeded quarter segments for $\mathrm{V}_{\mathrm{IH}}$, and has no visible evidence of dust or thermokarst (i.e., "No" for $\mathrm{V}_{\mathrm{DD}}$ and $\mathrm{V}_{\mathrm{TK}}$ ).

At the $800 \mathrm{~m}$ scale (Figure 54), the percent landscape disturbance $\left(\mathrm{V}_{\mathrm{LD}}\right)$, impediment to wildlife $\left(\mathrm{V}_{\mathrm{IW}}\right)$, and distance to roadway $\left(\mathrm{V}_{\mathrm{DR}}\right)$ are determined. WAA1 contains $0 \% \mathrm{~V}_{\mathrm{LD}}$, as indicated by a linear discolored area, $\mathrm{o}$ impeded quarter segments for $\mathrm{V}_{\mathrm{IW}}$, and the nearest road is located greater than $800 \mathrm{~m}$ from WAA1 for $\mathrm{V}_{\mathrm{DR}}$. The value for each variable assessed at the $80 \mathrm{~m}$ and $800 \mathrm{~m}$ scale is used to determine variable subindex scores using the wetland assessment calculator (Figure 55). 
Figure 51. Proposed alternative pads with access roads, and pad expansion.

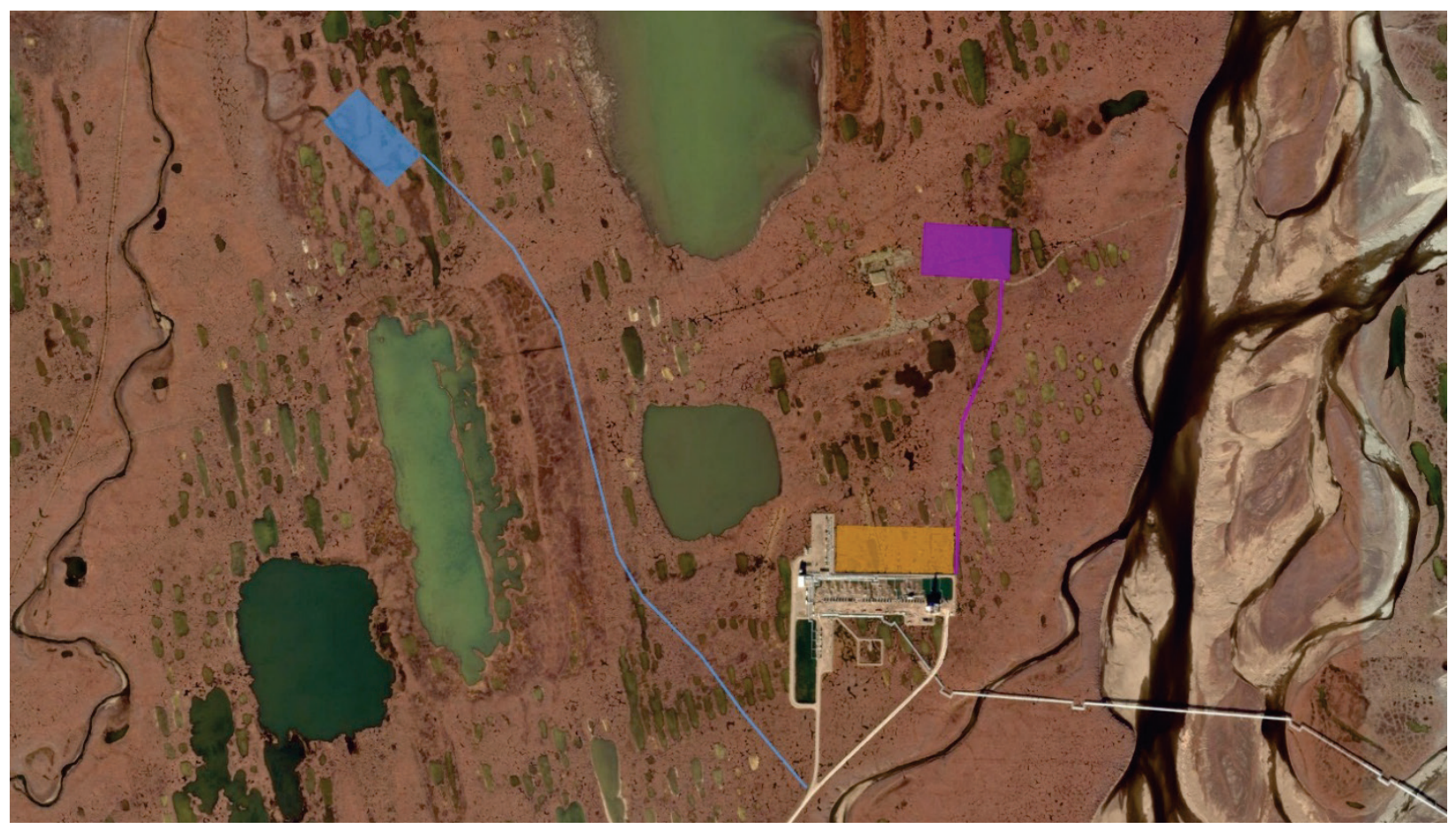

Figure 52. Proposed activities with designated WAAs.

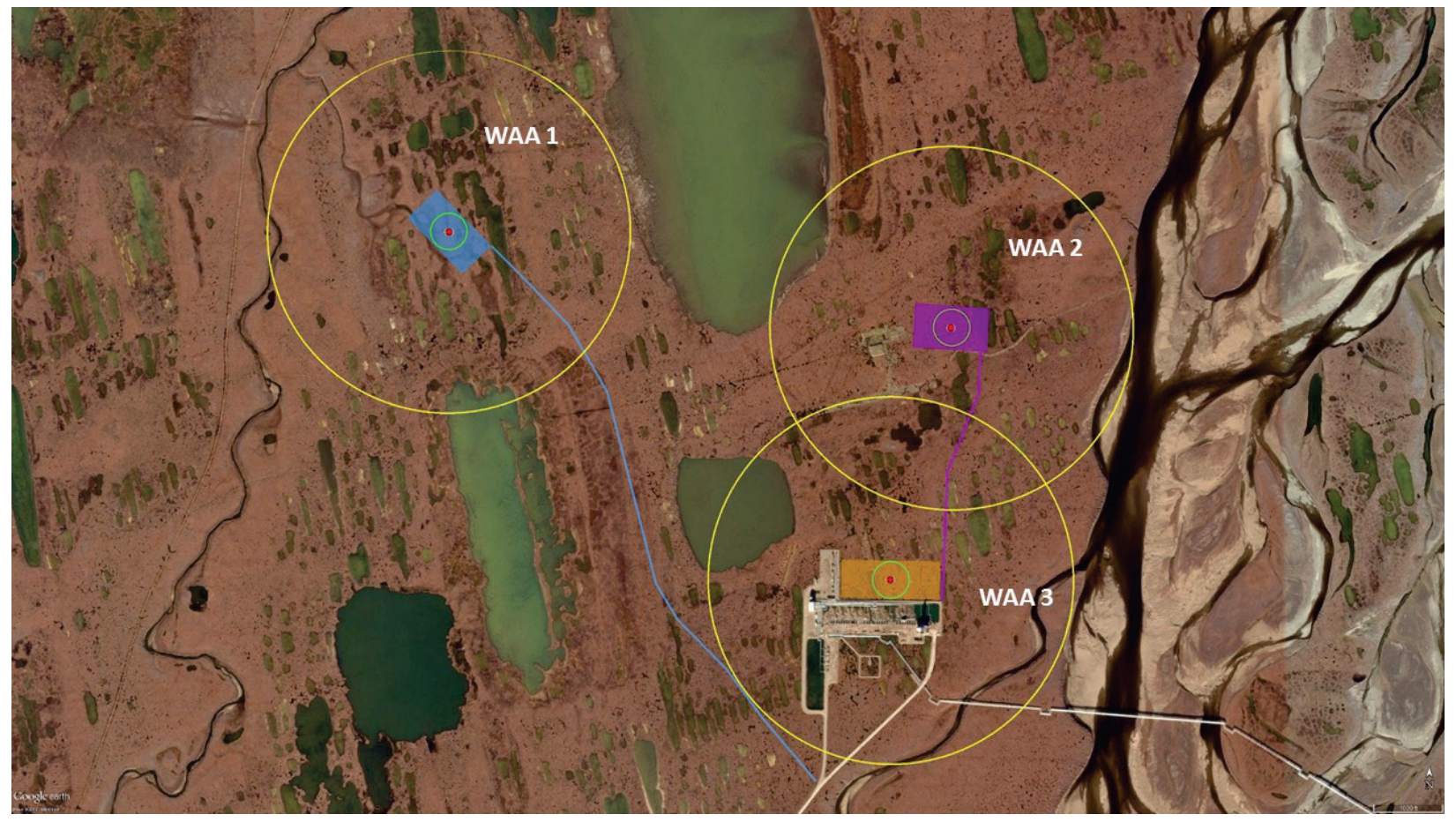


Figure 53. WAA1 at the $80 \mathrm{~m}$ scale.

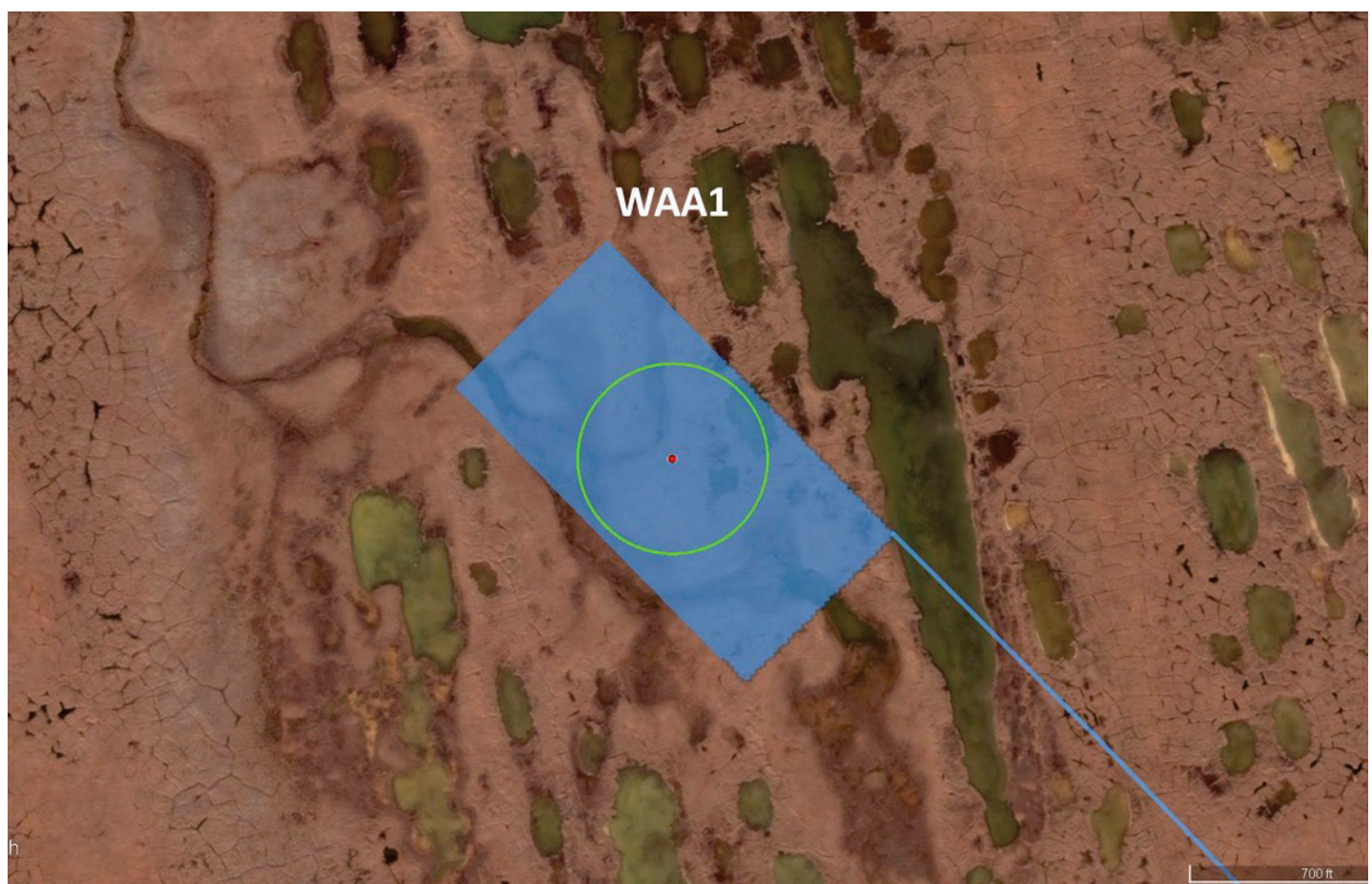

Figure 54. WAA1 at the $800 \mathrm{~m}$ scale. A linear discolored area crossing the northern portion of the plot indicates a prior disturbance. This disturbance is less than $1 \%$ of the area and, therefore, received a VLD subindex score of 0 .

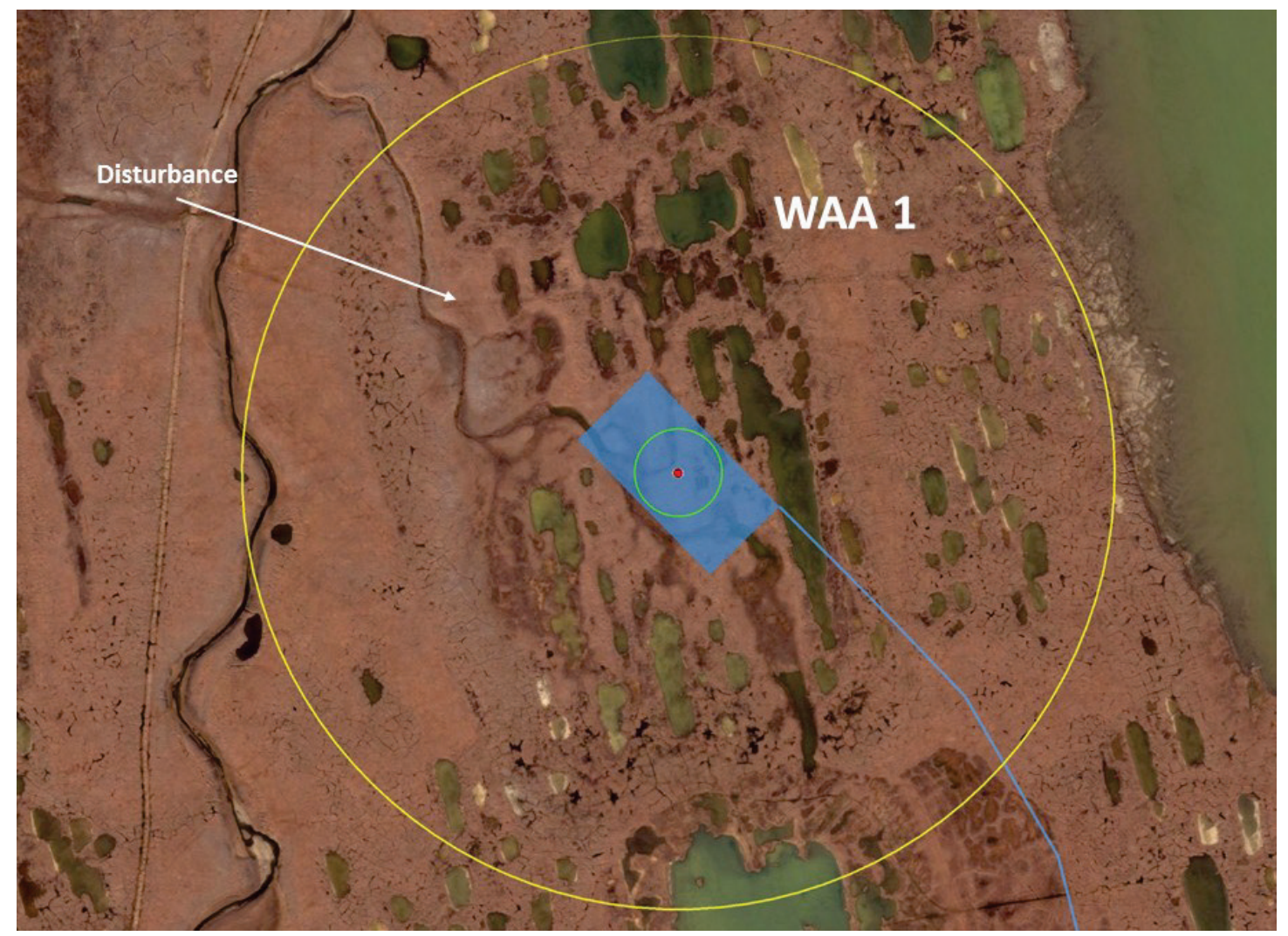


Figure 55. Example of completed off-site assessment for WAA1 using the wetland assessment calculator.

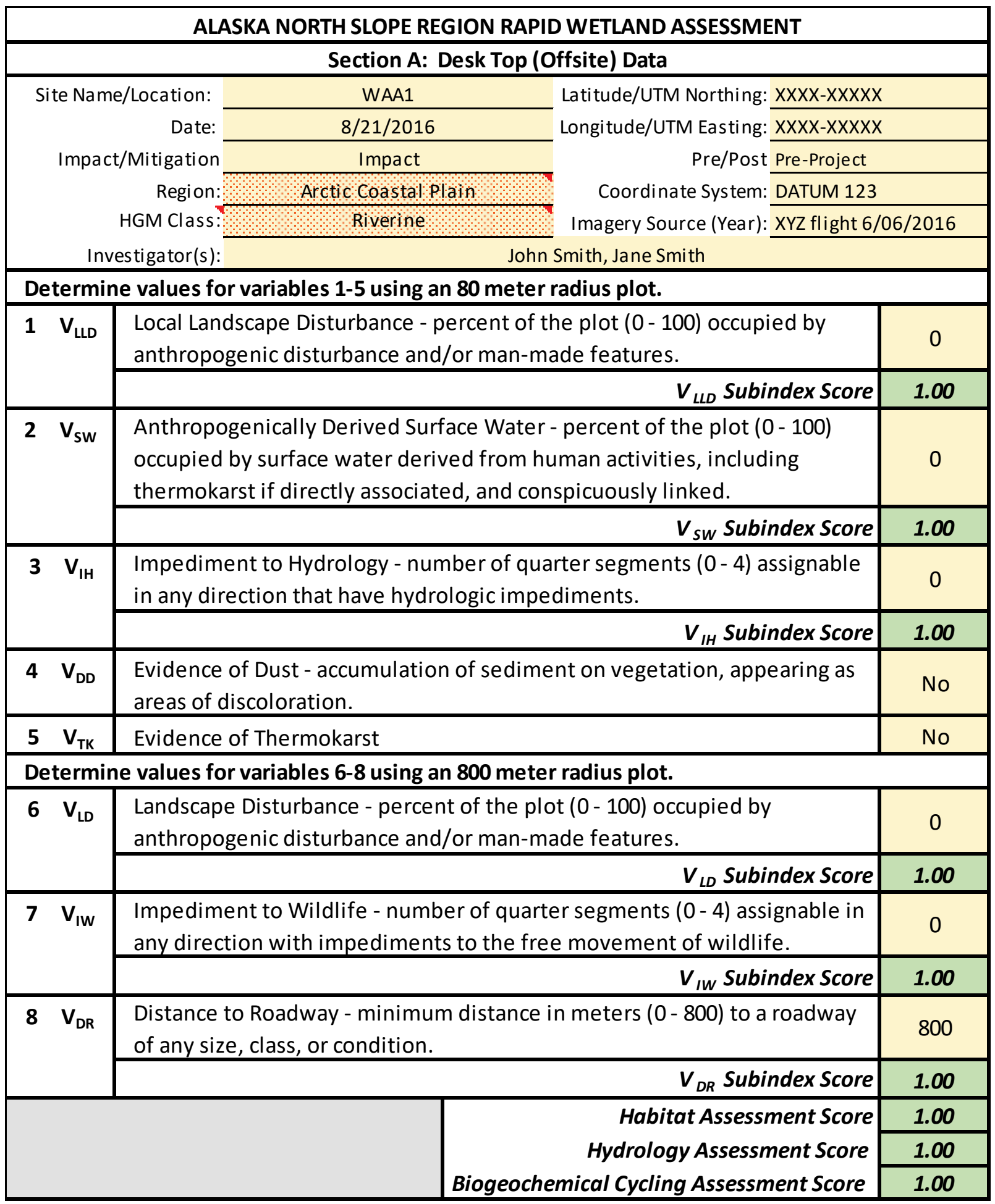

The variable subindex scores are used to calculate the habitat assessment score, hydrology assessment score, and the biogeochemical cycling assessment score. 


\section{Habitat Assessment Score}

The habitat assessment score is the minimum value of $V_{I W}$ and $V_{D R}$, plus the sum of $\mathrm{V}_{\mathrm{LD}}$ and $\mathrm{V}_{\mathrm{LLD}}$, divided by two, with the resulting quotient divided by two.

$\left[M I N\left(V_{I W}, V_{D R}\right)+\left(\left(V_{L D}+V_{L L D}\right) / 2\right)\right] / 2 \rightarrow[\operatorname{MIN}(1,1)+((1+1) / 2)] / 2=1.0$

\section{Hydrology Assessment Score}

The hydrology assessment score is the sum of $\mathrm{V}_{\mathrm{IH}}$ and $\mathrm{V}_{\mathrm{SW}}$, divided by two, multiplied by the sum of $\mathrm{V}_{\mathrm{LD}}$ and $\mathrm{V}_{\mathrm{LLD}}$, divided by two, with the resulting product raised to the $1 / 2$ power.

$$
\left[\left(\left(V_{I H}+V_{S W}\right) / 2\right) X\left(\left(V_{L D}+V_{L L D}\right) / 2\right)\right]^{1 / 2} \rightarrow[((1+1) / 2) X((1+1) / 2)]^{1 / 2}=1.0
$$

Biogeochemical Cycling Assessment Score

The biogeochemical cycling assessment score is the minimum value of $V_{L D}$ and VLLD.

$$
\operatorname{MIN}\left(V_{L D}, V_{L L D}\right) \rightarrow \operatorname{MIN}(1,1)=1.0
$$

\subsubsection{On-site evaluation of WAA1}

The on-site evaluation (when utilized) requires the establishment of two $30 \mathrm{~m}$ transects and four $1 \mathrm{~m}^{2}$ quadrats (Figure 56) within the $80 \mathrm{~m}$ radius area described above. Each of the on-site variables collected at WAA1 is described below.

$\mathrm{V}_{\mathrm{MT}}$ is calculated using a measure of absolute change in microtopography across the two transects. At WAA1, the measured microtopography value were entered into the wetland assessment calculator, resulting in an absolute microtopography value of 150 . This corresponds to a microtopography variable subindex score (Vмт) of 1.0 (Figures 43 and 57). 
Figure 56. Demonstrative photos for a site assessment of WAA1 situated within the ACP region.

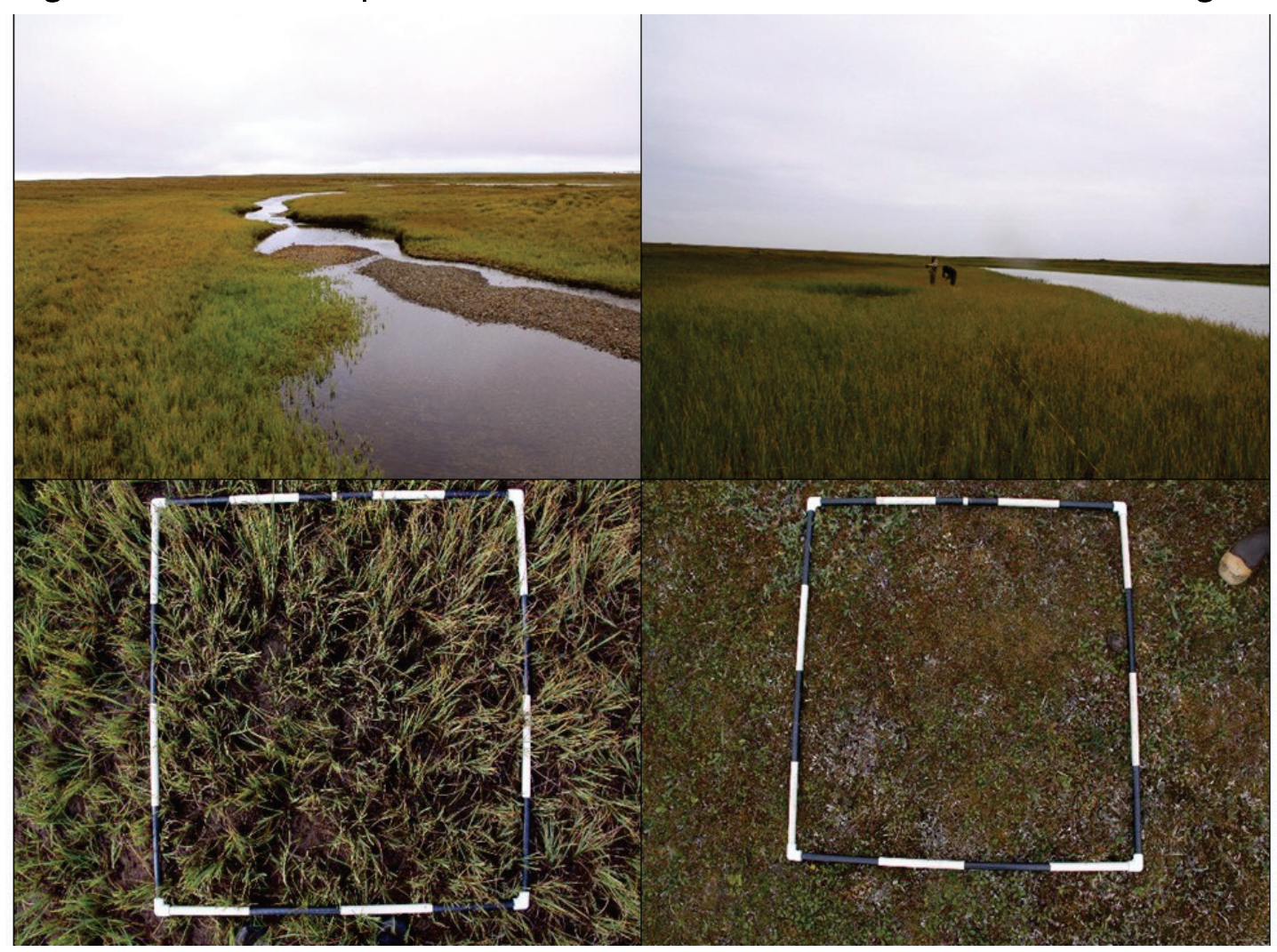

To calculate VsR, the average species richness of the four quadrat samples is used. In this example, quadrats displayed species richness values of 11, 12,9 , and 8 , resulting in an average species richness of 10 . The species richness count of 10 in the ACP equates to a VSR variable subindex score of 1.0 (Figures 45 and 57).

To calculate $\mathrm{V}_{\mathrm{BG}}$, the average bare ground percentage of the four quadrat samples is used. In this example, the quadrats exhibited bare ground values of $10 \%, 30 \%, 15 \%$, and $25 \%$, yielding an average bare ground value of $20 \%$. This equates to a $\mathrm{V}_{\mathrm{BG}}$ variable subindex score of 0.93 (Figure 48 and 57).

Note that evidence of dust deposition and evidence of thermokarst were both absent from WAA1, and neither were selected on the wetland assessment calculator. 
Figure 57. Example of wetland assessment calculator for WAA1 on-site variables.

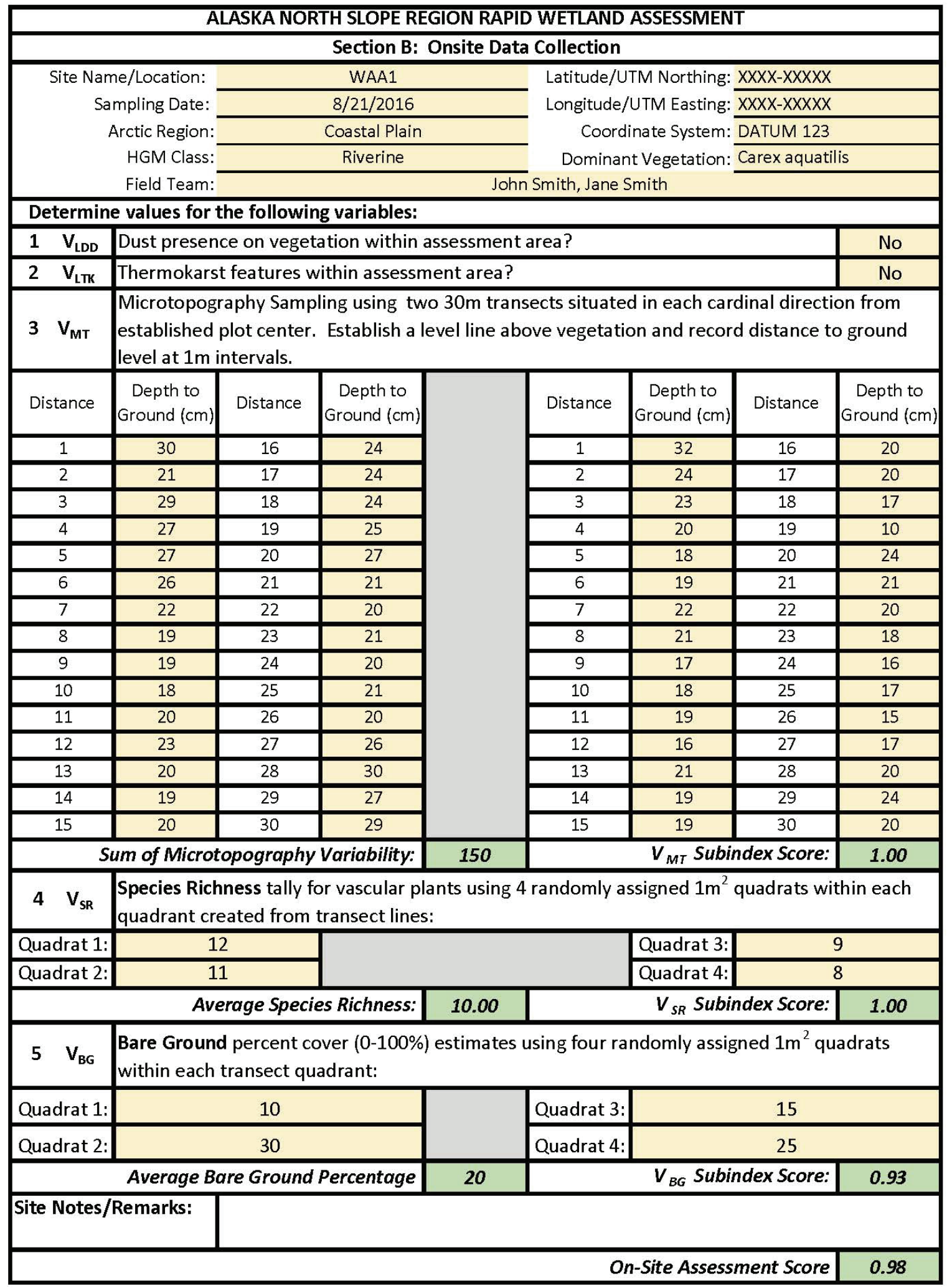


The variables subindex scores for $\mathrm{V}_{\mathrm{SR}}, \mathrm{V}_{\mathrm{BG}}$, and $\mathrm{V}_{\mathrm{MT}}$ are utilized to calculate the on-site assessment score modifier.

On-site Assessment Score Modifier:

$$
\left(V_{S R}+V_{B G}+V_{M T}\right) / 3 \rightarrow(1.0+0.93+1.0) / 3=0.98
$$

A summary of WAA1 assessment outcomes is presented in Table 2 and Figure 58. Summary tables can provide a valuable tool for reporting, documentation, and further analysis at site specific, project level, or regional scales.

Table 2. Summary of wetland assessment scores for WAA1.

\begin{tabular}{|l|c|}
\hline Wetland Assessment Component & Assessment Score \\
\hline Habitat & 1.0 \\
\hline Hydrology & 1.0 \\
\hline Biogeochemical cycling & 1.0 \\
\hline On-site modifier & 0.98 \\
\hline Average assessment score & 0.99 \\
\hline
\end{tabular}

Thus, the pre-project assessment score for WAA1 is 0.99. If the project results in conversion of land from jurisdictional wetlands to uplands, the post project assessment score will always be zero. 
Figure 58. Example of summary of assessment scores for WAA1 generated using the wetland assessment calculator.

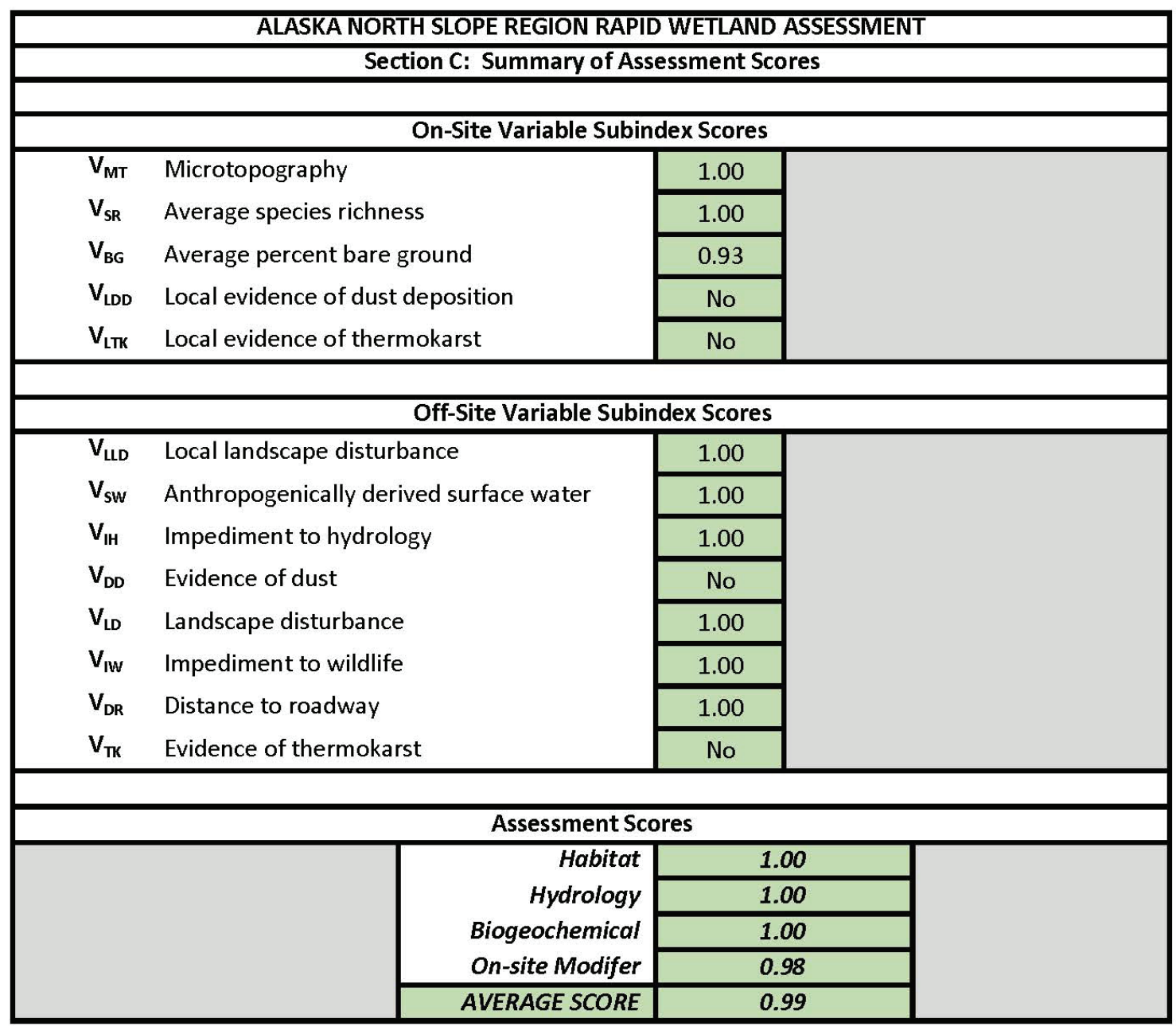

\subsubsection{Desktop (Off-site evaluation) of WAA2}

WAA2 is located in a depression wetland exhibiting several impacts (Figure 59). WAA2 contains $8 \% \mathrm{~V}_{\mathrm{LLD}}, 8 \% \mathrm{~V}_{\mathrm{SW}}$, thermokarst ( $\mathrm{V}_{\text {TK }}$ ) features are present, and there are 2 impeded quarter segments for $\mathrm{V}_{\mathrm{IH}}$. There is no evidence of dust deposition $\left(\mathrm{V}_{\mathrm{DD}}\right)$.

At the $800 \mathrm{~m}$ scale (Figure 60), WAA2 contains $8 \% \mathrm{~V}_{\mathrm{LD}}$, o impeded quarter segments for $\mathrm{VIW}_{\mathrm{IW}}$, and the nearest roadway is greater than $800 \mathrm{~m}$ $\left(V_{D R}\right)$. The values for each variable assessed at the $80 \mathrm{~m}$ and $800 \mathrm{~m}$ scale are used to determine variable subindex scores using the wetland assessment calculator (Figure 61). 
Figure 59. WAA2 at the $80 \mathrm{~m}$ scale.

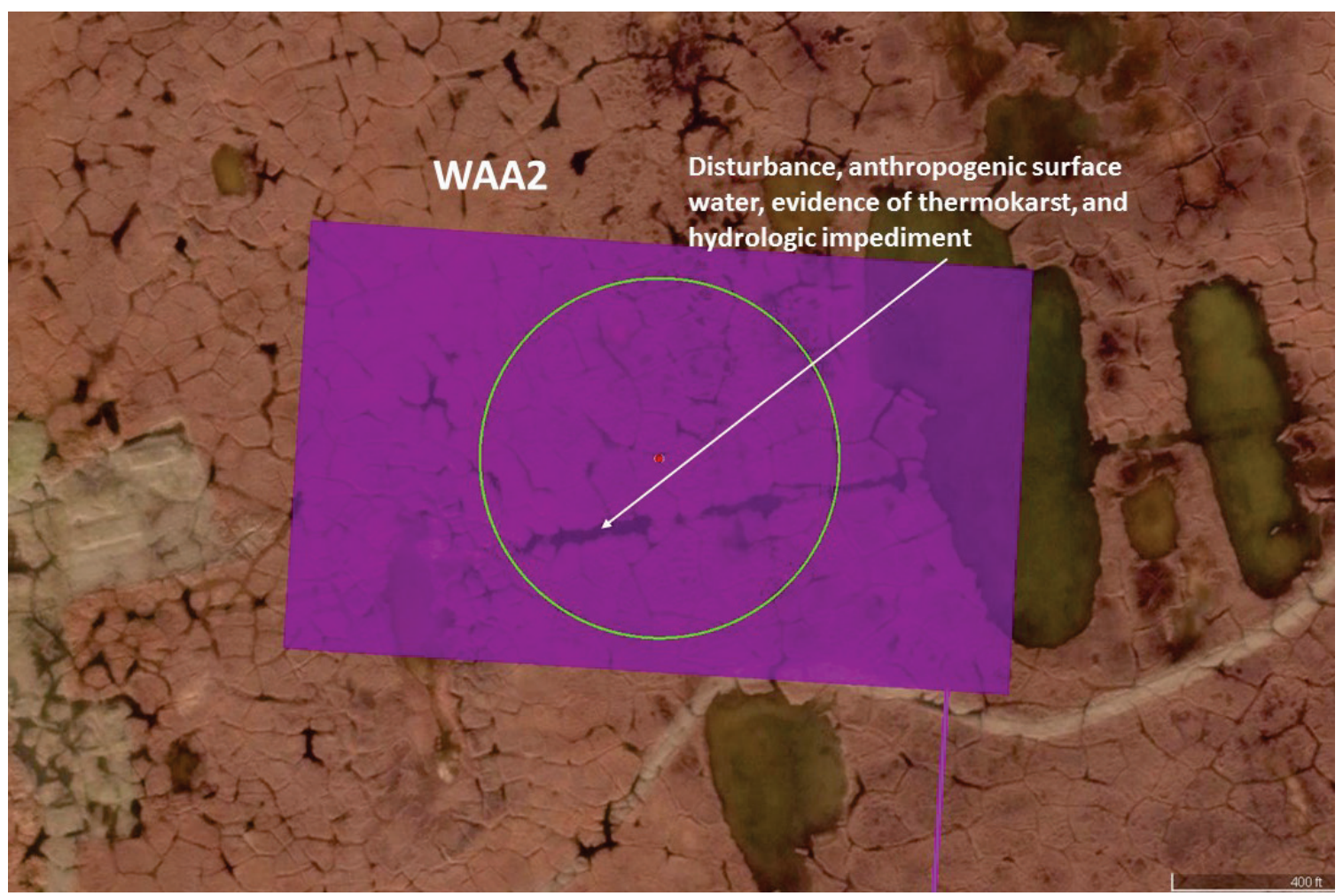

Figure 60. WAA2 at the $800 \mathrm{~m}$ scale.

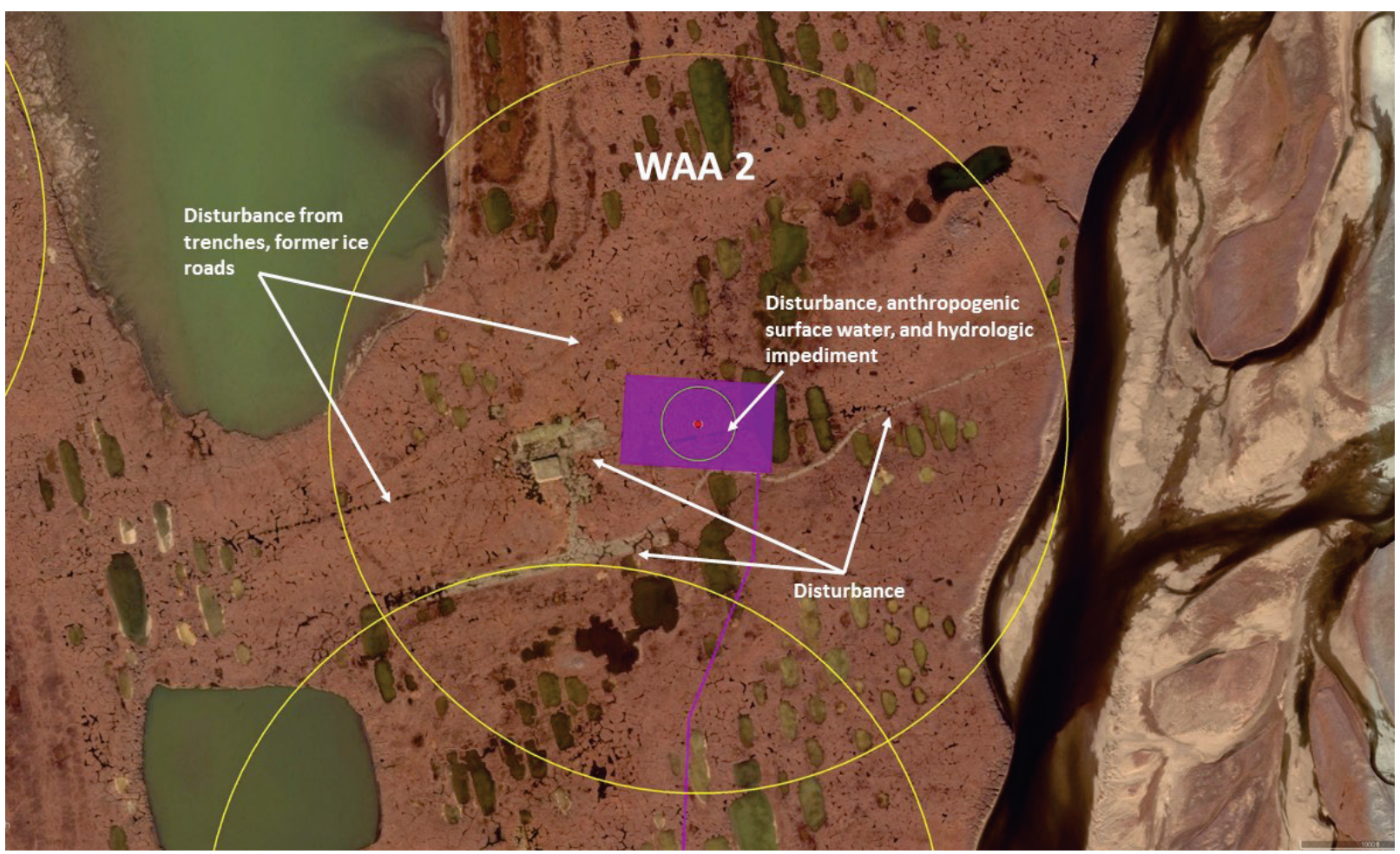


Figure 61. Example of off-site assessment scores for WAA2.

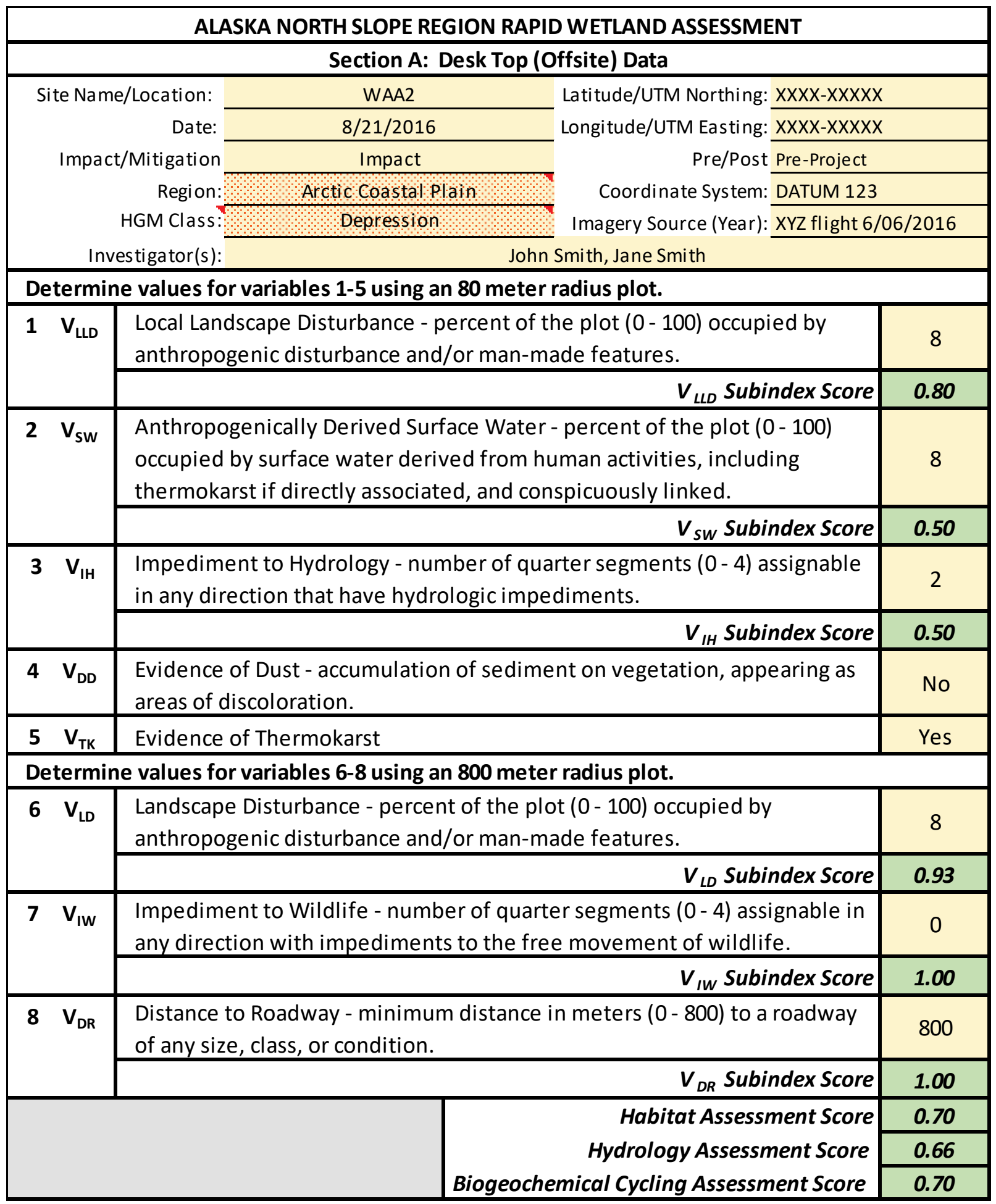

The variable subindex scores are used to calculate the habitat assessment score, hydrology assessment score, and the biogeochemical cycling assessment score. 
Habitat Assessment Score:

$\left[\operatorname{MIN}\left(V_{I W}, V_{D R}\right)+\left(\left(V_{L D}+V_{L L D}\right) / 2\right)\right] / 2 \rightarrow[\operatorname{MIN}(1,1)+((0.93+0.80) / 2)] / 2=0.70$

Hydrology Assessment Score:

$\left[\left(\left(V_{I H}+V_{S W}\right) / 2\right) X\left(\left(V_{L D}+V_{L L D}\right) / 2\right)\right]^{1 / 2} \rightarrow[((0.5+0.5) / 2) X((0.93+0.80) / 2)]^{1 / 2}=0.66$

Biogeochemical Cycling Assessment Score:

$$
\operatorname{MIN}\left(V_{L D}, V_{L L D}\right) \rightarrow \operatorname{MIN}(0.93,0.80)=0.70
$$

\subsubsection{On-site evaluation of WAA2}

The WAA2 variable subindex scores for $\mathrm{V}_{\mathrm{SR}}, \mathrm{V}_{\mathrm{BG}}$, and $\mathrm{V}_{\mathrm{MT}}$, are used to calculate the on-site assessment score modifier (Figures 62 and 63). The measured microtopography values were entered into the wetland assessment calculator, which yielded in an absolute microtopography value of 40 , which corresponds to a microtopography variable subindex score ( $\left.\mathrm{V}_{\mathrm{MT}}\right)$ of 0.80 (Figures 43 and 63). Quadrats displayed species richness values of 3, 2, 3 , and 1, resulting in an average species richness of 2.25. An average species richness of 2.25 in the ACP equates to a $V_{S R}$ variable subindex score of 0.23 . Because the site is dominated (i.e., >50\% of vegetative cover) by Arctophila fulva, which naturally occurs in near monotypic stands, the $V_{\text {SR variable }}$ subindex score is automatically adjusted to 1.0 (Figures 44 and 63). The percentage of bare ground in the four quadrats was determined to be $40 \%$, $30 \%, 35 \%$, and $55 \%$. The average bare ground percentage of $40 \%$ equates to a $V_{B G}$ score of 0.61 (Figure 63). No thermokarst or dust deposition was identified within the on-site assessment area.

The variables subindex scores for $\mathrm{V}_{\mathrm{SR}}, \mathrm{V}_{\mathrm{BG}}$, and $\mathrm{V}_{\mathrm{MT}}$ are utilized to calculate the on-site assessment score modifier (Figure 64).

On-site Assessment Score Modifier:

$$
\left(V_{S R}+V_{B G}+V_{M T}\right) / 3 \rightarrow(1.0+0.61+0.8) / 3=0.80
$$

Thus, the pre-project assessment score for WAA2 is 0.72. If the project results in conversion of land from jurisdictional wetlands to uplands, the post project assessment score will always be zero. 
Figure 62. On-site photos for WAA2 situated within the ACP, note the dominance of Arctophila fulva, which results in a species richness variable subindex score of 1.0.

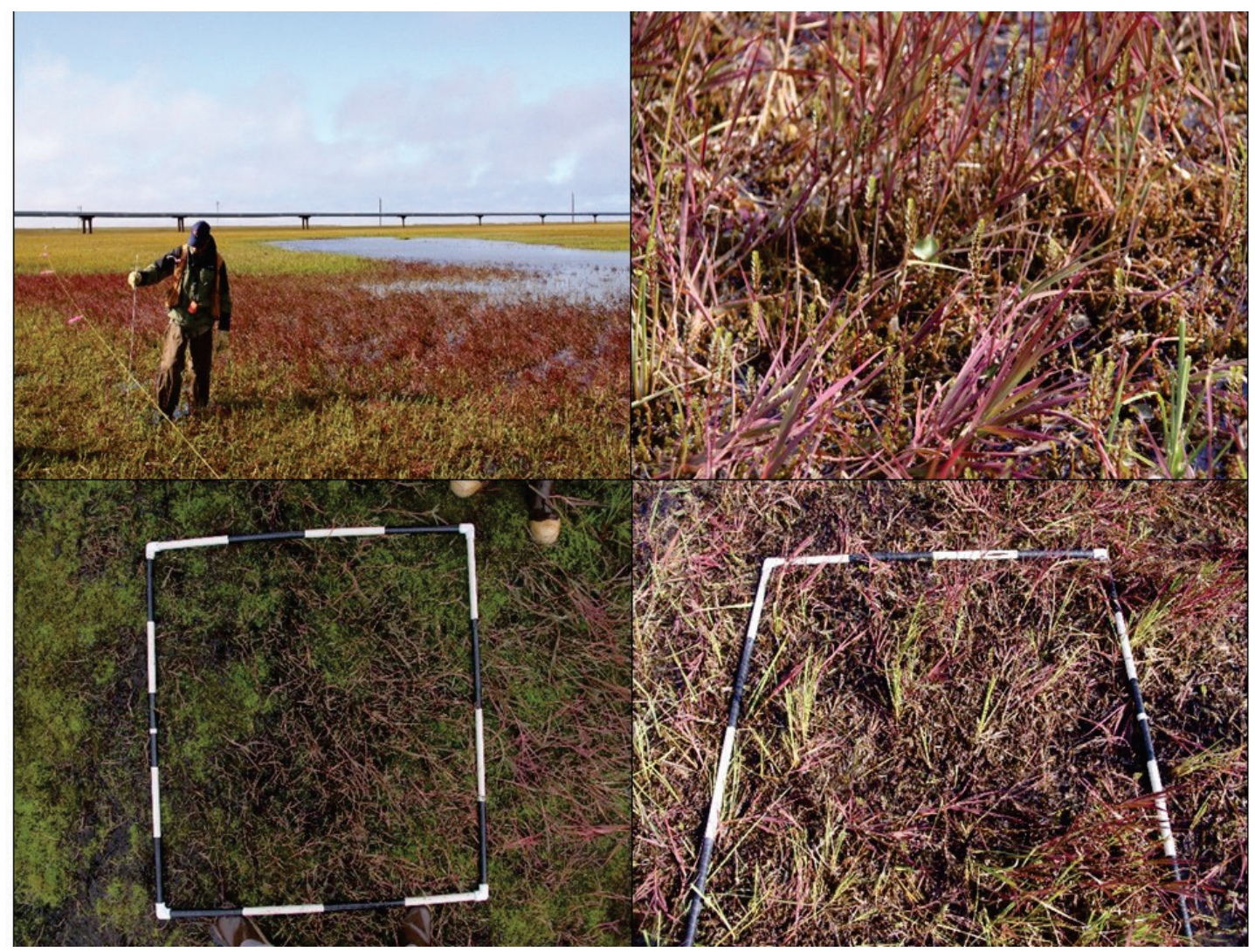


Figure 63. Example of on-site data for WAA2, which was determined by using the wetland assessment calculator.

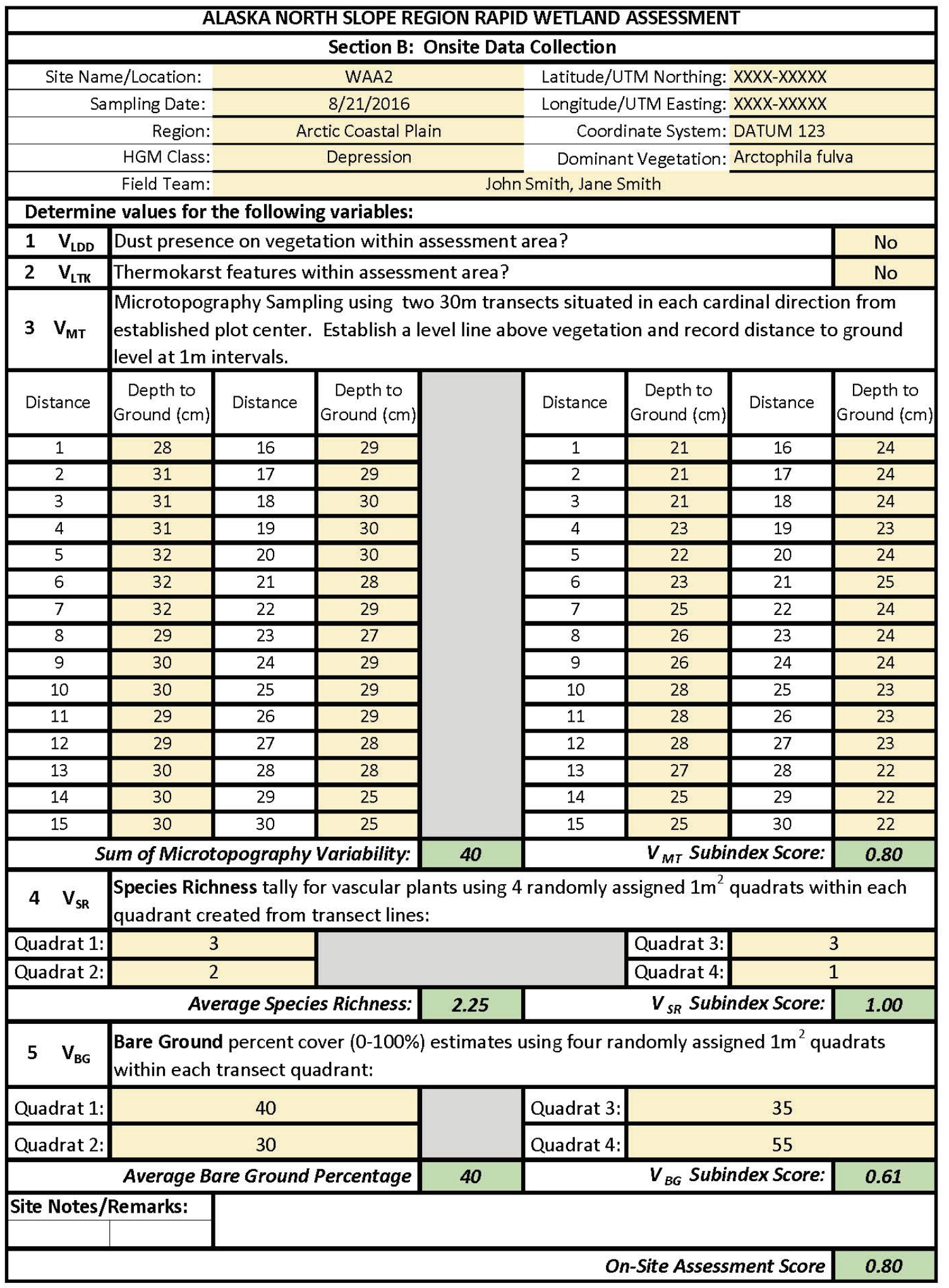


Figure 64. Example of summary of assessment scores for WAA2, which was generated using the wetland assessment calculator.

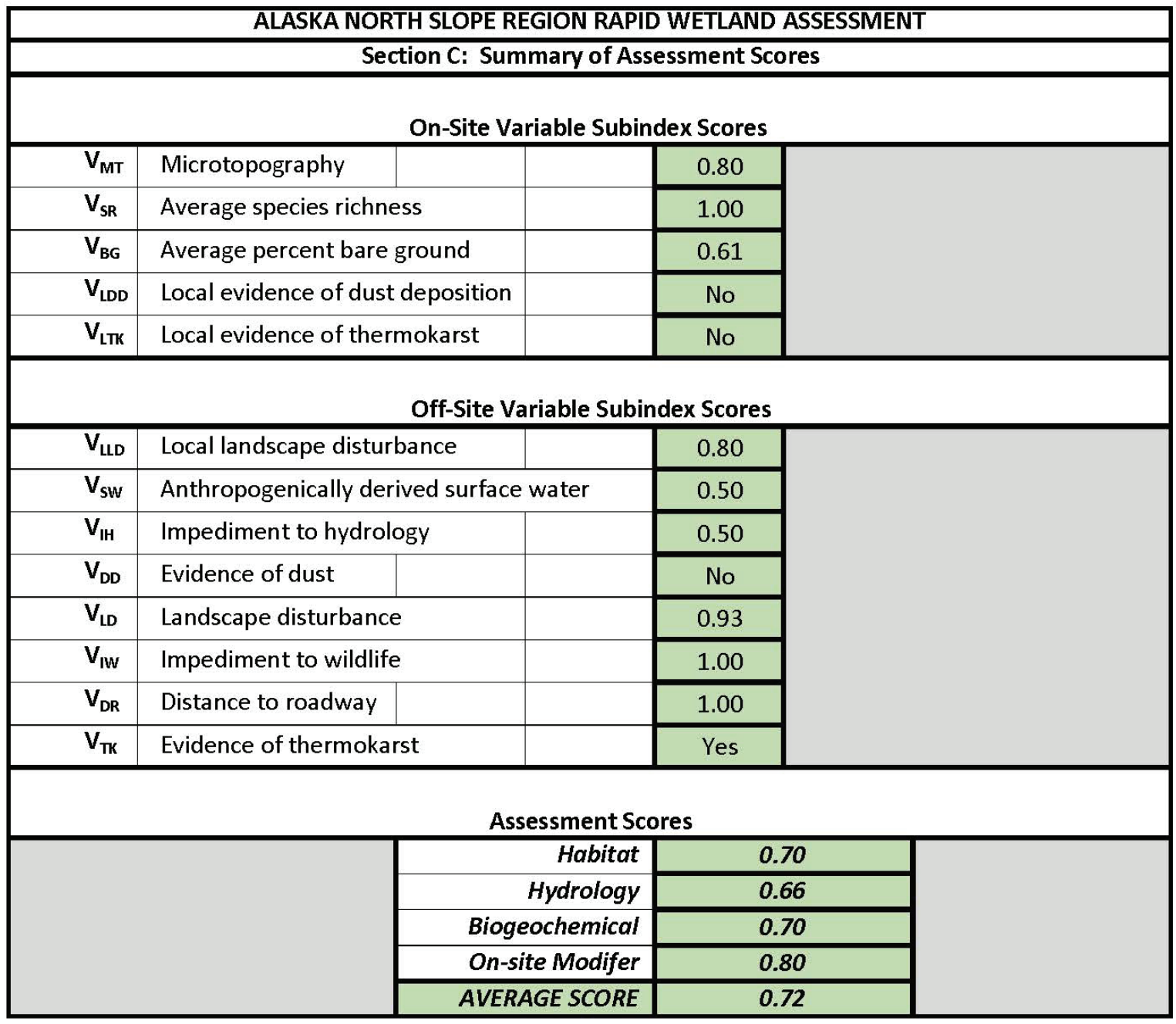

\subsubsection{Desktop (Off-site) evaluation of WAA3}

WAA3 is located in a depression wetland area immediately adjacent to existing infrastructure (Figure 65). WAA3 contains 15\% VLLD, 10\% VSW, some thermokarst ( $\mathrm{V}_{\mathrm{TK}}$ ) features, 2 impeded quarter segments for $\mathrm{V}_{\mathrm{IH}}$, and no visible evidence of dust $\left(\mathrm{V}_{\mathrm{DD}}\right)$. Because evidence of thermokarst $\left(\mathrm{V}_{\mathrm{TK}}\right)$ is present, the three assessment component scores are limited to a maximum of 0.70 .

At the $800 \mathrm{~m}$ scale (Figure 66), WAA3 contains 20\% $\mathrm{V}_{\mathrm{LD}}, 3$ impeded quarter segments for VIW (shaded portion), and is $52 \mathrm{~m}$ from the nearest roadway $\left(V_{D R}\right)$. The value for each variable assessed at the $80 \mathrm{~m}$ and 800 $\mathrm{m}$ scale is used to determine variable subindex scores using the wetland assessment calculator (Figure 67). 
Figure 65 . WAA3 at the $80 \mathrm{~m}$ scale.

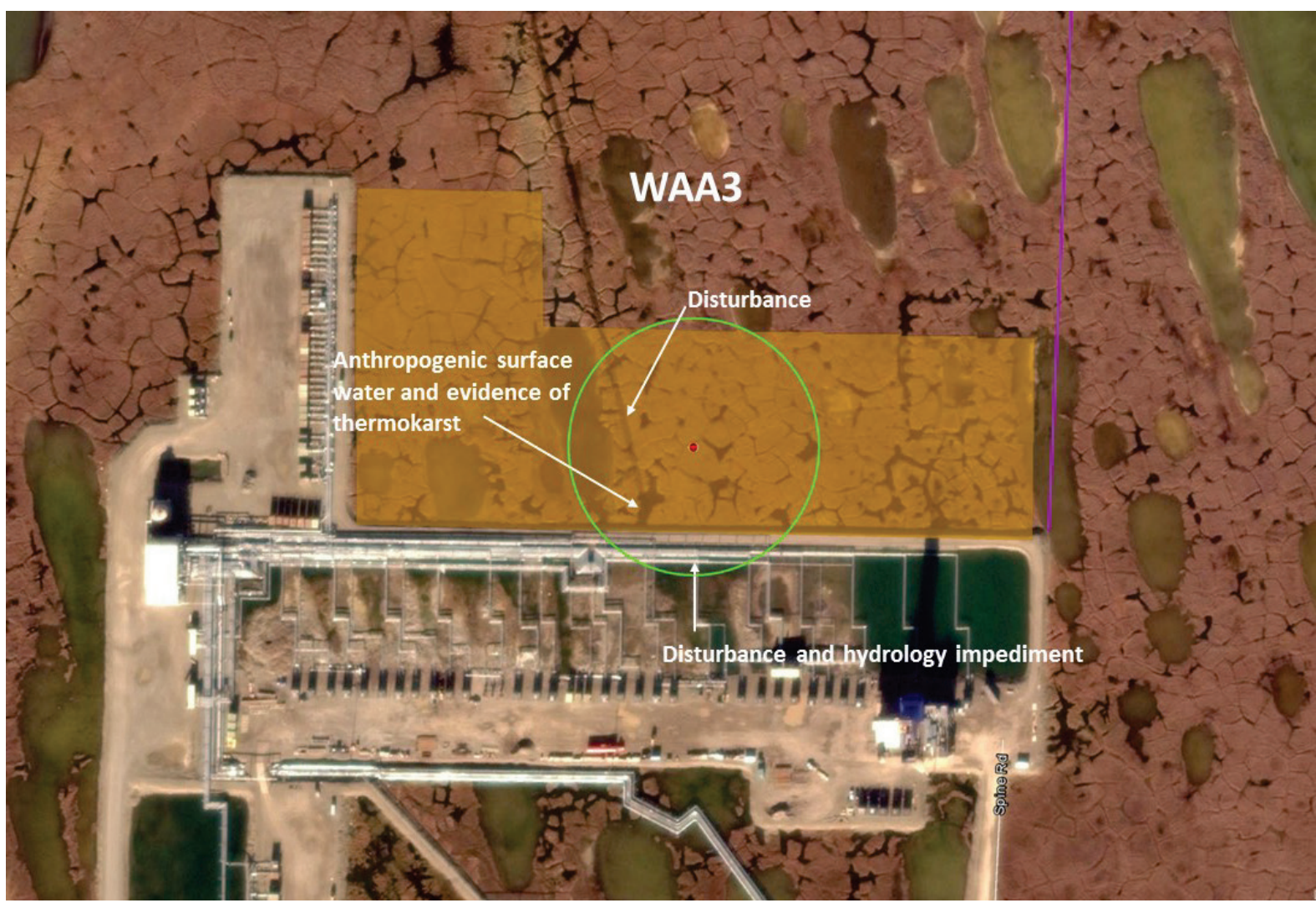

Figure 66. WAA3 at the $800 \mathrm{~m}$ scale. Shaded portion of the plot is impeded to wildlife movement.

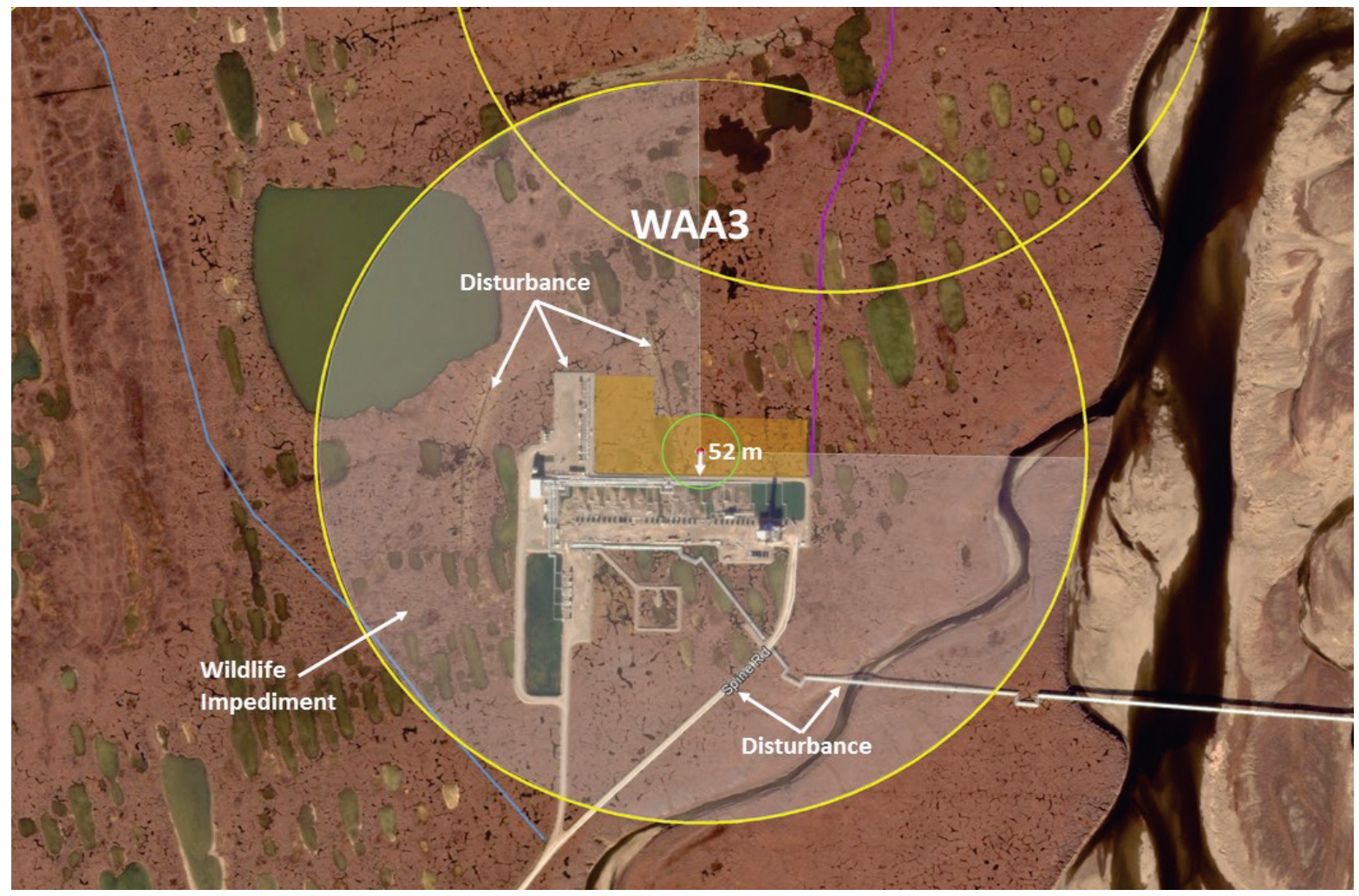


Figure 67. Example of wetland assessment calculator used to determine off-site scores for WAA3.

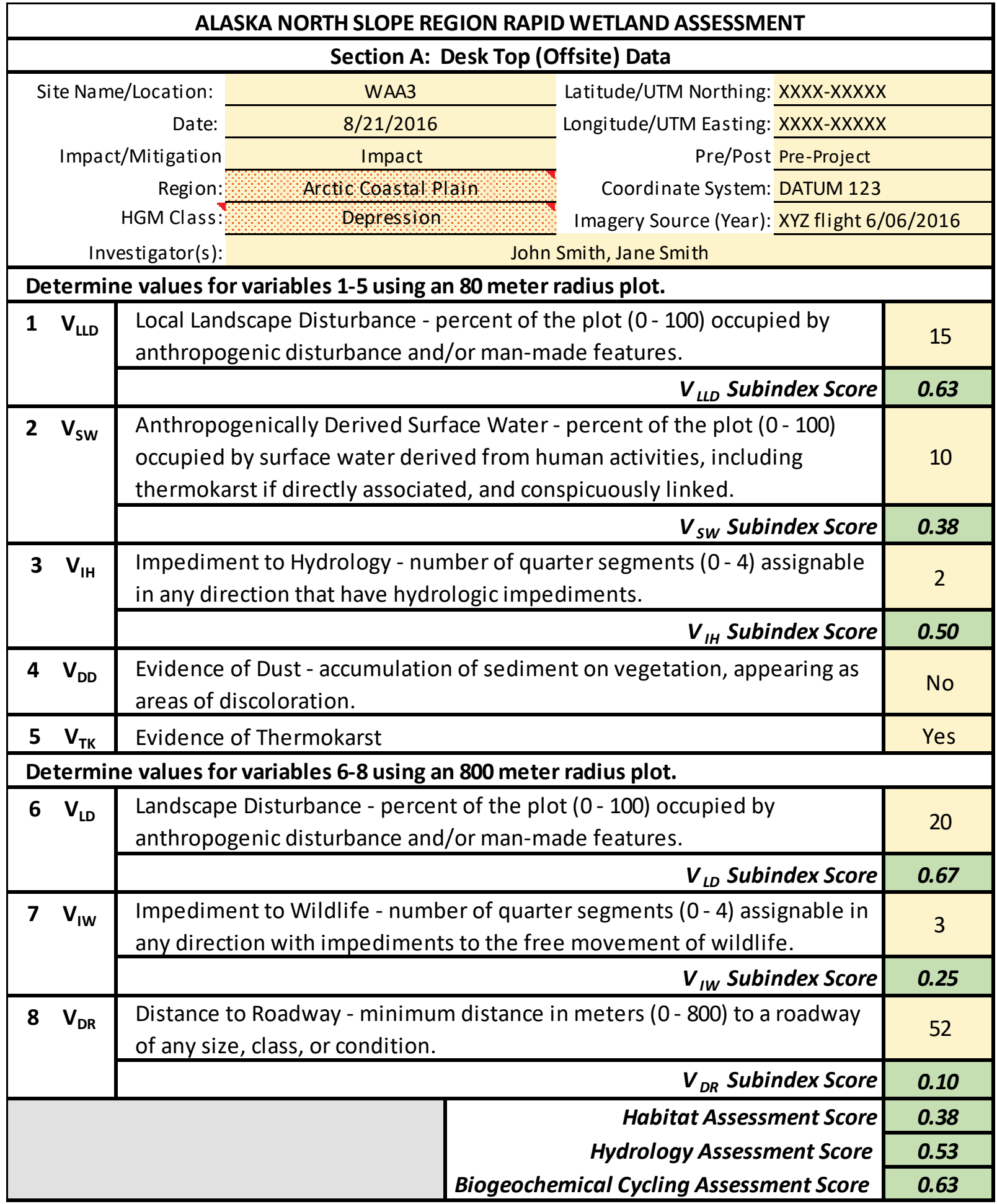

The variable subindex scores are used to calculate the habitat assessment score, hydrology assessment score, and the biogeochemical cycling assessment score. 
Habitat Assessment Score

$\left[\operatorname{MIN}\left(V_{I W}, V_{D R}\right)+\left(\left(V_{L D}+V_{L L D}\right) / 2\right)\right] / 2 \rightarrow[\operatorname{MIN}(0.25,0.1)+((0.67+0.63) / 2)] / 2=0.38$

Hydrology Assessment Score

$\left[\left(\left(V_{I H}+V_{S W}\right) / 2\right) X\left(\left(V_{L D}+V_{L L D}\right) / 2\right)\right]^{1 / 2} \rightarrow[((0.5+0.38) / 2) X((0.67+0.63) / 2)]^{1 / 2}=0.53$

Biogeochemical Cycling Assessment Score

The biogeochemical cycling assessment score is the minimum value of $\mathrm{V}_{\mathrm{LD}}$ and VLLD.

$$
\operatorname{MIN}\left(V_{L D}, V_{L L D}\right) \rightarrow \operatorname{MIN}(0.67,0.63)=0.63
$$

\subsubsection{On-site evaluation of WAA3}

The WAA3 variable subindex scores for $\mathrm{V}_{\mathrm{SR}}, \mathrm{V}_{\mathrm{BG}}$, and $\mathrm{V}_{\mathrm{MT}}$ are used to calculate the on-site assessment score modifier (Figures 68 and 69). Local evidence of thermokarst was observed at the sample location, limiting wetland assessment scores to a maximum value of 0.70 .

Figure 68. Demonstrative photos for on-site assessment of WAA3 situated within the ACP and directly adjacent to a gravel pad.

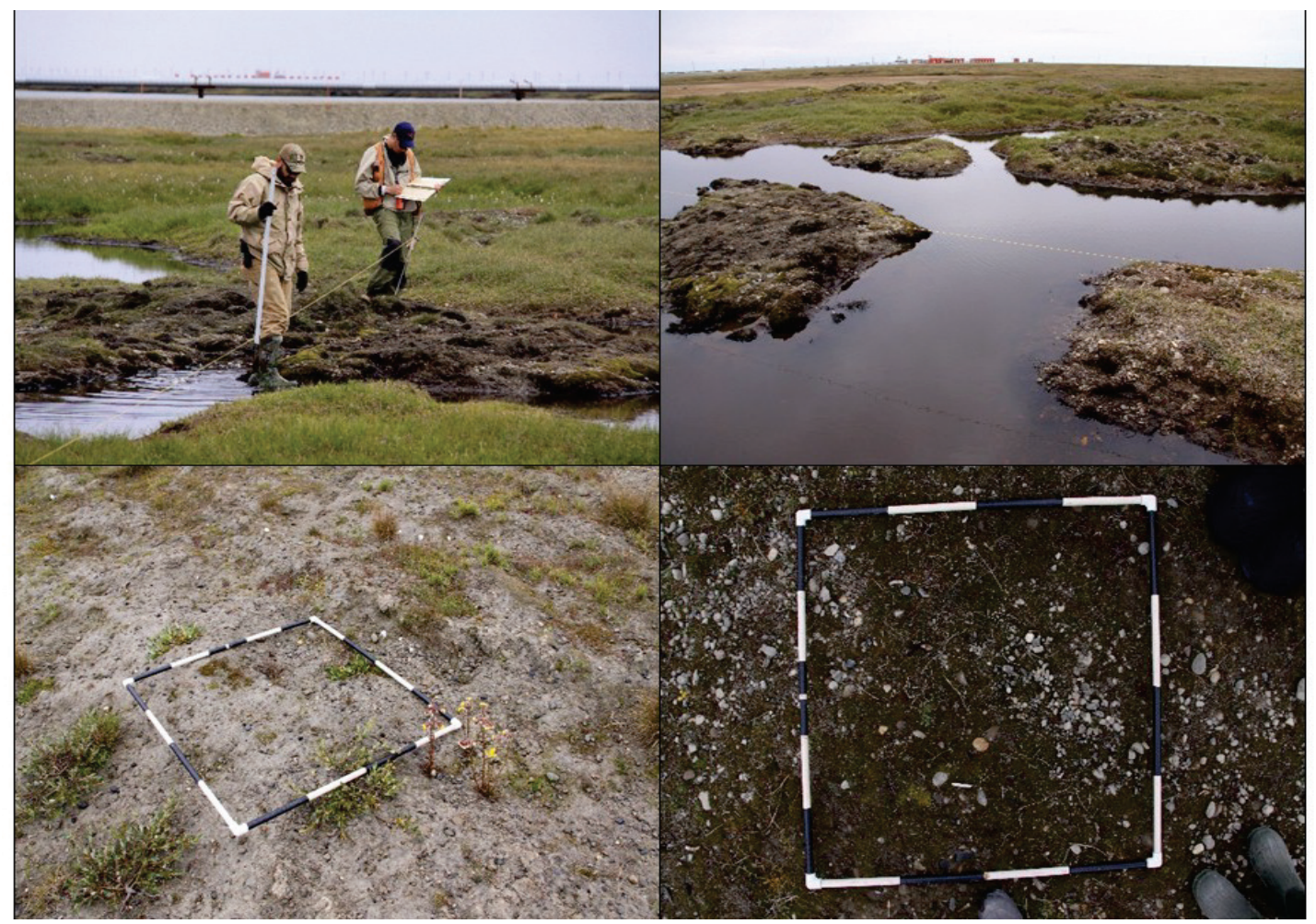


Figure 69. Example of on-site wetland assessment scores, which were determined by using the wetland assessment calculator.

\begin{tabular}{|c|c|c|c|c|c|c|c|c|}
\hline \multicolumn{9}{|c|}{ ALASKA NORTH SLOPE REGION RAPID WETLAND ASSESSMENT } \\
\hline \multicolumn{9}{|c|}{ Section B: Onsite Data Collection } \\
\hline \multirow{5}{*}{\multicolumn{2}{|c|}{$\begin{array}{r}\text { Site Name/Location: } \\
\text { Sampling Date: } \\
\text { Arctic Region: } \\
\text { HGM Class: } \\
\text { Field Team: }\end{array}$}} & \multicolumn{3}{|c|}{ WAA3 } & \multicolumn{4}{|c|}{ Latitude/UTM Northing: XXXX-XXXXX } \\
\hline & & \multicolumn{3}{|c|}{$8 / 21 / 2016$} & \multicolumn{4}{|c|}{ Longitude/UTM Easting: $\overline{X X X X-X X X X X}$} \\
\hline & & \multicolumn{3}{|c|}{ Coastal Plain } & \multicolumn{4}{|c|}{ Coordinate System: DATUM 123} \\
\hline & & \multicolumn{3}{|c|}{ Depression } & \multicolumn{3}{|c|}{ Dominant Vegetation: Other... } & \\
\hline & & \multicolumn{7}{|c|}{ John Smith, Jane Smith } \\
\hline \multicolumn{9}{|c|}{ Determine values for the following variables: } \\
\hline $1 V_{\text {LDD }}$ & \multicolumn{7}{|c|}{ Dust presence on vegetation within assessment area? } & No \\
\hline $2 V_{\text {LTK }}$ & \multicolumn{7}{|c|}{ Thermokarst features within assessment area? } & Yes \\
\hline $3 \mathrm{~V}_{\mathrm{MT}}$ & \multicolumn{8}{|c|}{$\begin{array}{l}\text { Microtopography Sampling using two } 30 \mathrm{~m} \text { transects situated in each cardinal direction from } \\
\text { established plot center. Establish a level line above vegetation and record distance to ground } \\
\text { level at } 1 \mathrm{~m} \text { intervals. }\end{array}$} \\
\hline Distance & $\begin{array}{c}\text { Depth to } \\
\text { Ground }(\mathrm{cm})\end{array}$ & Distance & $\begin{array}{c}\text { Depth to } \\
\text { Ground }(\mathrm{cm})\end{array}$ & & Distance & $\begin{array}{c}\text { Depth to } \\
\text { Ground }(\mathrm{cm})\end{array}$ & Distance & $\begin{array}{l}\text { Depth to } \\
\text { Ground }(\mathrm{cm})\end{array}$ \\
\hline 1 & 29 & 16 & 25 & & 1 & 30 & 16 & 30 \\
\hline 2 & 20 & 17 & 26 & & 2 & 18 & 17 & 32 \\
\hline 3 & 24 & 18 & 25 & & 3 & 18 & 18 & 35 \\
\hline 4 & 27 & 19 & 24 & & 4 & 27 & 19 & 32 \\
\hline 5 & 28 & 20 & 23 & & 5 & 28 & 20 & 32 \\
\hline 6 & 26 & 21 & 21 & & 6 & 28 & 21 & 28 \\
\hline 7 & 28 & 22 & 17 & & 7 & 27 & 22 & 30 \\
\hline 8 & 29 & 23 & 19 & & 8 & 25 & 23 & 35 \\
\hline 9 & 14 & 24 & 13 & & 9 & 27 & 24 & 30 \\
\hline 10 & 27 & 25 & 10 & & 10 & 28 & 25 & 28 \\
\hline 11 & 28 & 26 & 22 & & 11 & 27 & 26 & 24 \\
\hline 12 & 27 & 27 & 19 & & 12 & 30 & 27 & 20 \\
\hline 13 & 27 & 28 & 13 & & 13 & 30 & 28 & 21 \\
\hline 14 & 27 & 29 & 21 & & 14 & 29 & 29 & 24 \\
\hline 15 & 26 & 30 & 30 & & 15 & 28 & 30 & 23 \\
\hline \multicolumn{4}{|c|}{ Sum of Microtopography Variability: } & 185 & \multicolumn{3}{|c|}{$V_{M T}$ Subindex Score: } & 0.43 \\
\hline $4 \mathrm{~V}_{\mathrm{SR}}$ & \multicolumn{8}{|c|}{$\begin{array}{l}\text { Species Richness tally for vascular plants using } 4 \text { randomly assigned } 1 \mathrm{~m}^{2} \text { quadrats within each } \\
\text { quadrant created from transect lines: }\end{array}$} \\
\hline Quadrat 1: & \multicolumn{2}{|c|}{7} & & & & Quadrat 3: & \multicolumn{2}{|c|}{5} \\
\hline Quadrat 2: & \multicolumn{2}{|c|}{5} & & & & Quadrat 4: & \multicolumn{2}{|c|}{7} \\
\hline & \multicolumn{2}{|c|}{ Average Species Richness: } & & 6.00 & & $v_{S R}$ Subir & dex Score: & 0.60 \\
\hline $5 \quad \mathrm{~V}_{\mathrm{BG}}$ & $\begin{array}{l}\text { Bare Grounc } \\
\text { within each }\end{array}$ & percent c & $\begin{array}{l}\text { over }(0-100 \%) \\
\text { ladrant: }\end{array}$ & timate & using four ra & ndomly assig & ned $1 m^{2}$ qua & adrats \\
\hline Quadrat 1: & & 40 & & & Quadrat 3: & & 65 & \\
\hline Quadrat 2: & & 80 & & & Quadrat 4: & & 55 & \\
\hline & Average $B C$ & re Ground & Percentage & 60 & & $V_{B G}$ Subir & dex Score: & 0.29 \\
\hline Site Notes/1 & Remarks: & & & & & & & \\
\hline & & & & & & n-Site Assess & nent Score & 0.44 \\
\hline
\end{tabular}


At WAA3, the measured microtopography values were entered into the wetland assessment calculator, resulting in an absolute microtopography value of 185 . This is an example of the development of unusually uneven surfaces. The result corresponds to a microtopography variable subindex score ( $\mathrm{V}_{\mathrm{MT}}$ ) of 0.43 (Figures 44 and 69). In this example, quadrats displayed species richness values of $7,5,5$, and 7 respectively, resulting in an average species richness of 6 . The species richness count of 6 in the $\mathrm{ACP}$ equates to a $\mathrm{V}_{\mathrm{SR}}$ variable subindex score of 0.60 (Figures 45 and 69).

The percentage of bare ground in the 4 quadrats was determined to be $40 \%, 80 \%, 65 \%$, and $55 \%$. The bare ground average percentage of $60 \%$ equates to a $V_{\text {BG }}$ subindex score of 0.29 (Figure 69).

The variable subindex scores for $\mathrm{V}_{\mathrm{SR}}, \mathrm{V}_{\mathrm{BG}}$, and $\mathrm{V}_{\mathrm{MT}}$ are utilized to calculate the on-site assessment score modifier (Figure 64). The summary of scores for WAA3 can be seen in Figure 70.

On-site Assessment Score Modifier:

$$
\left(V_{S R}+V_{B G}+V_{M T}\right) / 3 \rightarrow(0.60+0.29+0.43) / 3=0.44
$$

Thus, the pre-project assessment score for WAA3 is 0.49. If the project results in a conversion of land from jurisdictional wetlands to uplands, the post-project assessment score will always be zero.

\subsubsection{Alternatives analysis for WAA1, WAA2, and WAA3}

After calculating scores for the three WAAs, pre-project results are compiled for comparative analysis, as shown in Table 3. Post-project scores are all zero since the result of the discharge is the conversion of land from jurisdictional wetlands to uplands. WAA1 is located in an undisturbed area, resulting in an average wetland assessment score of 0.99. WAA2 displayed some disturbance, resulting in an average score of 0.72. WAA3 is located in a disturbed landscape with pads, roads, and utility lines present, and received the lowest average score at 0.49 . $\mathrm{V}_{\text {TK }}$ and $\mathrm{V}_{\text {LTK }}$ are present at WAA3; however, they have no effect on the scores because the components already score below the limiting values. Figure 71 provides an example of how assessment scores can be displayed graphically. 
Figure 70. Summary of wetland assessment scores generated for WAA3 using the wetland assessment calculator.

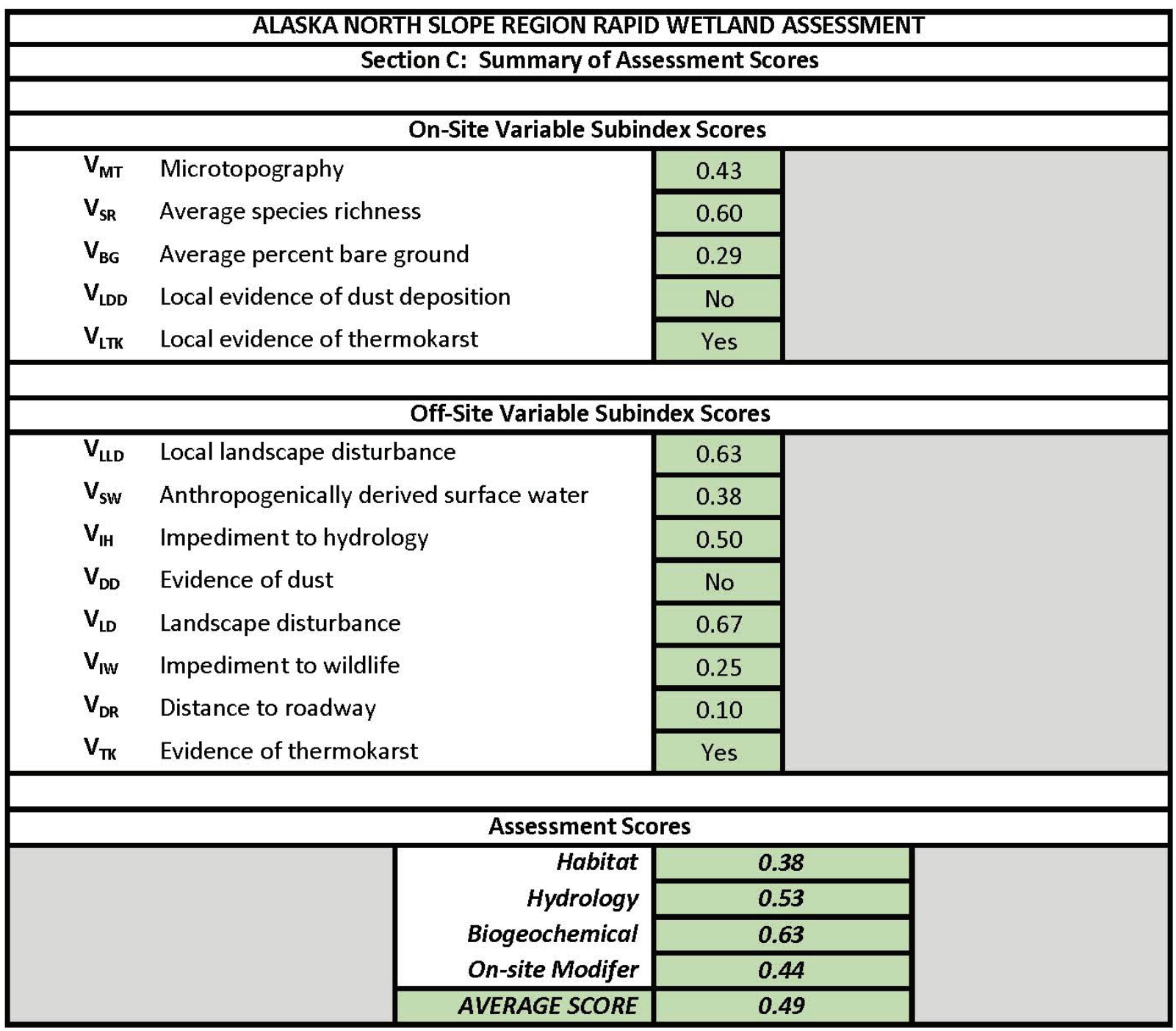

Table 3. Wetland assessment component scores for WAA1, WAA2, and WAA3.

\begin{tabular}{|l|c|c|c|}
\hline Wetland Assessment Component & WAA1 & WAA2 & WAA3 \\
\hline Habitat & 1.00 & 0.70 & 0.38 \\
\hline Hydrology & 1.00 & 0.66 & 0.53 \\
\hline Biogeochemical cycling & 1.00 & 0.70 & 0.63 \\
\hline On-site modifier & 0.98 & 0.80 & 0.44 \\
\hline Average score & 0.99 & 0.72 & 0.49 \\
\hline
\end{tabular}


Figure 71. Wetland assessment component scores for WAA1, WAA2, and WAA3.

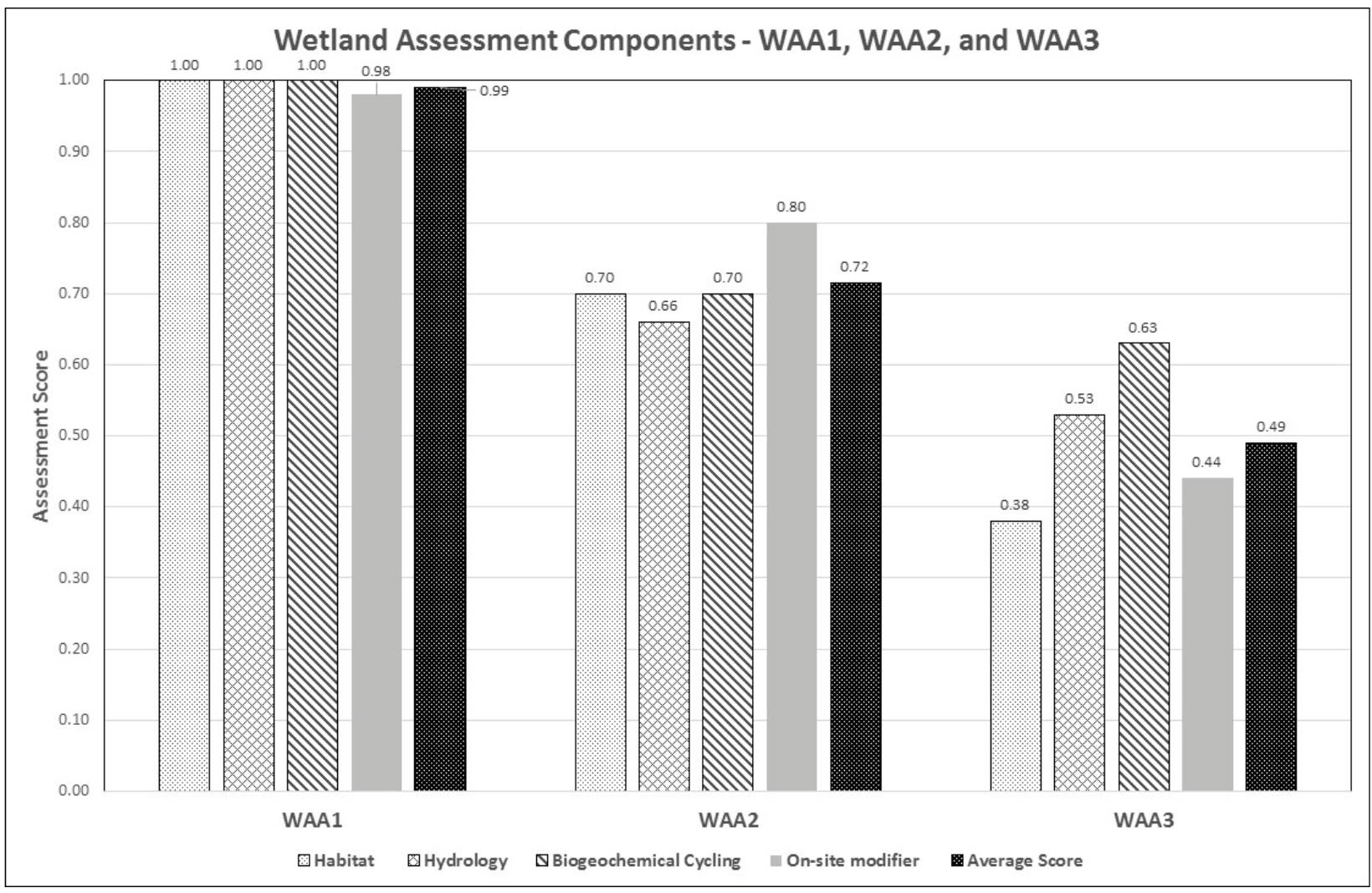

Figure 71 demonstrates that WAA1 received the highest assessment scores and likely perform wetland functions at a higher level than the other locations. WAA3 received the lowest scores and is likely the lowest functioning site. WAA2 scored in the intermediate range. As a result, the alternatives that are associated with each assessment area differ in the level of proposed impacts to wetlands within the region.

The resulting values can be incorporated into the Alaska District's CDM.

\subsection{Scenario 2 - Assessment of linear project areas}

The following is an example scenario that demonstrates the evaluation of a proposed development project along a linear corridor. This scenario utilizes desktop (off-site) variables only. The construction of a well-pad and access road are proposed near an existing well-pad, road, and aboveground utility line (Figure 72). The pad would occupy 8 ha and require a $5900 \mathrm{~m}$ by $6 \mathrm{~m}$ access road (3.54 ha). 
Figure 72. Proposed well-pad and access road.

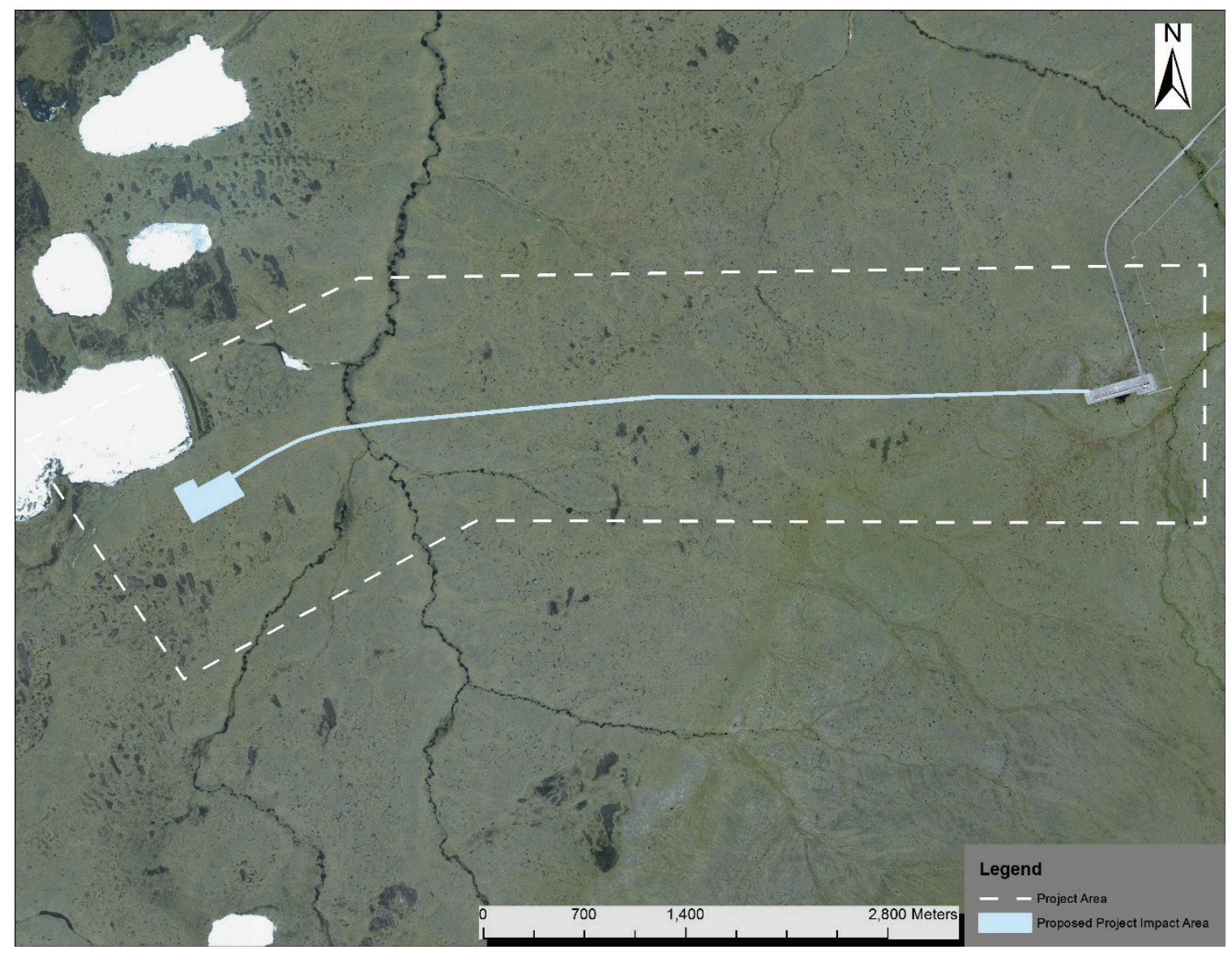

To effectively capture the variety of wetland resources and levels of wetland disturbances present within the project area, implement three individual WAAs (Figure 73). WAA1 is located in a flats wetland adjacent to an existing pad-site and road, representing a disturbed area. WAA2 is located in an undisturbed riverine wetland, within the footprint of the proposed access road. WAA3 is located in an undisturbed flats wetland at the site of the proposed well-pad.

\subsubsection{WAA1}

At the $80 \mathrm{~m}$ scale (Figure 74), WAA1 contains $15 \% \mathrm{~V}_{\mathrm{LLD}}$, o percent $\mathrm{V}_{\mathrm{Sw}}$, 1 impeded quarter segment for $\mathrm{V}_{\mathrm{IH}}$, thermokarst $\left(\mathrm{V}_{\mathrm{TK}}\right)$ features, and no visible evidence of dust (“No" for $\mathrm{VDD}$ ).

At the $800 \mathrm{~m}$ scale (Figure 74), WAA1 contains $6 \% \mathrm{~V}_{\mathrm{LD}}, 2$ impeded quarter segments for $\mathrm{V}_{\mathrm{IW}}$, and the nearest roadway is located $42 \mathrm{~m}$ from the sample area $\left(V_{D R}\right)$. The values for each variable assessed at the $80 \mathrm{~m}$ and $800 \mathrm{~m}$ scale are used to determine variable subindex scores via the wetland assessment calculator (Figure 75). 
Figure 73. Project area with three WAAs identified.

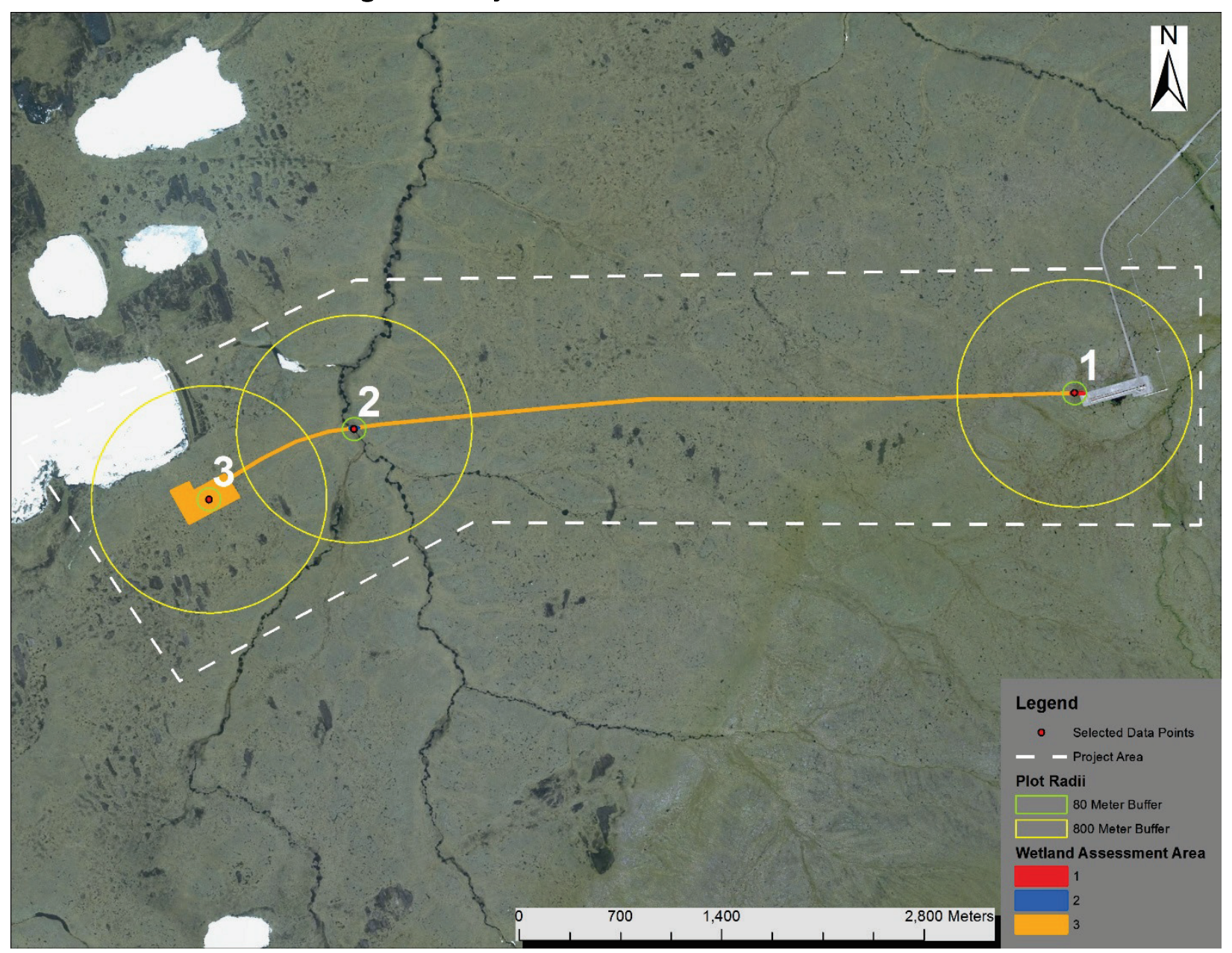


Figure 74. WAA1 located adjacent to an existing well-pad. The green shaded $1 / 4$ segment of the $80 \mathrm{~m}$ radius area has impediments to hydrology. The gray shaded portion of the $800 \mathrm{~m}$ radius area has impediments to wildlife.

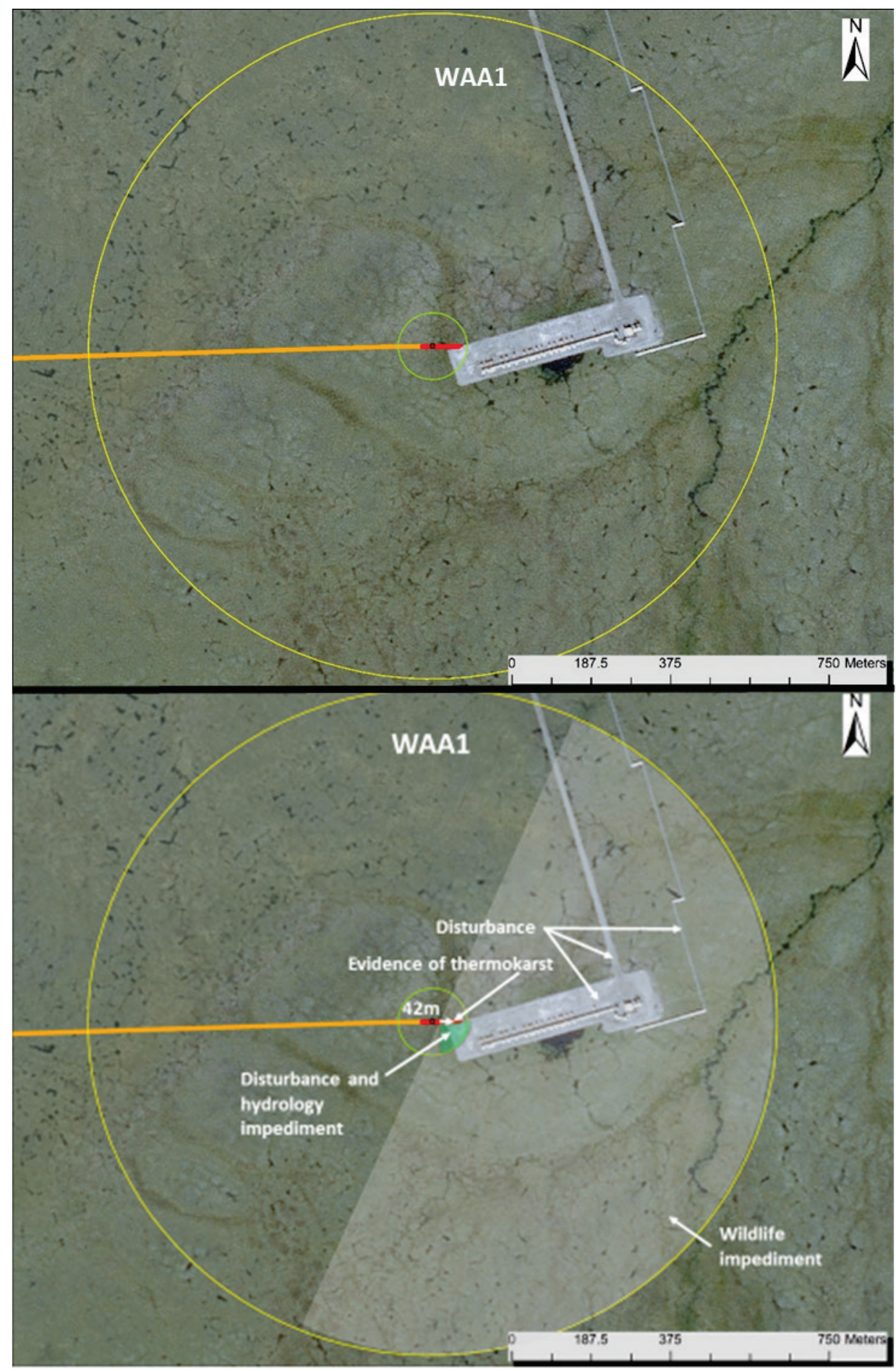


Figure 75. Example of Desktop (off-site) assessment scores for WAA1 using the wetland assessment calculator.

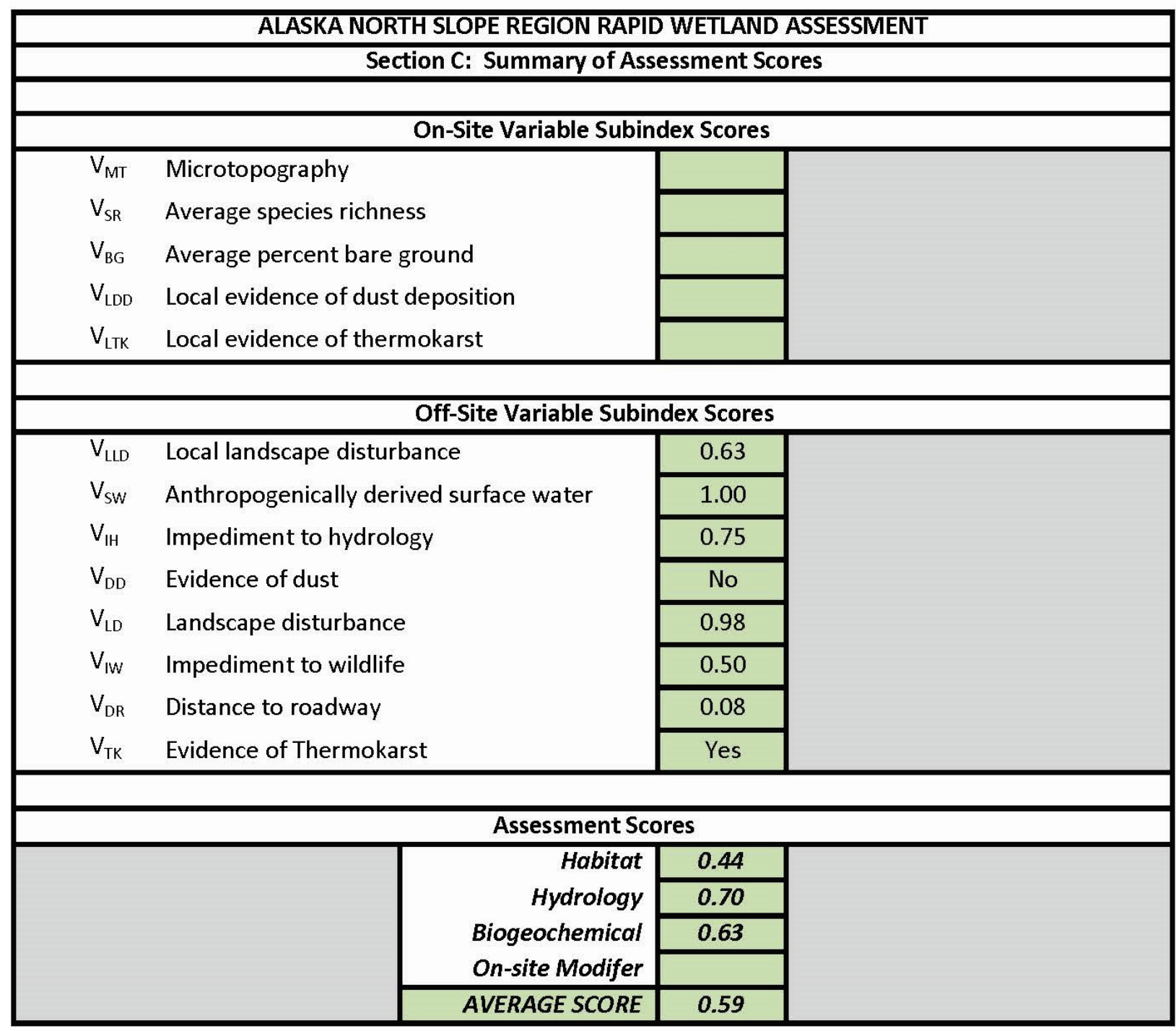

The variable subindex scores are used to calculate the habitat assessment score, hydrology assessment score, and the biogeochemical cycling assessment score. Because evidence of thermokarst ( $\mathrm{V}_{\mathrm{TK}}$ ) is present, the three assessment component scores are limited to a maximum value of 0.7 .

\section{Habitat Assessment Score}

The habitat assessment score is the minimum value of $V_{I W}$ and VDR, plus the sum of $V_{L D}$ and $V_{L L D}$, divided by two, with the resulting quotient divided by two.

$$
\left[M I N\left(V_{I W}, V_{D R}\right)+\left(\left(V_{L D}+V_{L L D}\right) / 2\right)\right] / 2 \rightarrow[M I N(0.50,0.08)+((0.98+0.63) / 2)] / 2=0.44
$$


Because the score is less than 0.7, the $\mathrm{V}_{\mathrm{TK}}$ limit does not apply.

Hydrology Assessment Score

The hydrology assessment score is the sum of $\mathrm{V}_{\mathrm{IH}}$ and $\mathrm{V}_{\mathrm{sw}}$, divided by two, multiplied by the sum of $\mathrm{V}_{\mathrm{LD}}$ and $\mathrm{V}_{\mathrm{LLD}}$, divided by two, with the resulting product raised to the $1 / 2$ power.

$$
\left[\left(\left(V_{I H}+V_{S W}\right) / 2\right) X\left(\left(V_{L D}+V_{L L D}\right) / 2\right)\right]^{1 / 2} \rightarrow[((0.75+1.00) / 2) X((0.98+0.63) / 2)]^{1 / 2}=0.81
$$

Evidence of $\mathrm{V}_{\text {тк }}$ limits the maximum hydrology score to 0.70 .

Biogeochemical Cycling Assessment Score

The biogeochemical cycling assessment score is the minimum value of $V_{L D}$ and VLLD.

$$
\operatorname{MIN}\left(V_{L D}, V_{L L D}\right) \rightarrow \operatorname{MIN}(0.98,0.63)=0.63
$$

Because the score in less than 0.7, the $\mathrm{V}_{\text {Tर }}$ limit does not apply.

Average Assessment Score

The average pre-project assessment score is the average of the habitat, hydrology, and biogeochemical cycling scores: $(0.44+0.70+0.63) / 3=$ 0.59

If the project results in conversion of land from jurisdictional wetlands to uplands, the post-project assessment score will always be zero.

\subsubsection{WAA2 and WAA3}

WAA2 and WAA3 are located in undisturbed areas that represent two distinct wetland classes. As a result, each must be evaluated individually. At the $80 \mathrm{~m}$ scale (Figure 76), WAA2 and WAA3 each contain $0 \% \mathrm{~V}_{\mathrm{LLD}}, 0 \%$ $\mathrm{V}_{\mathrm{SW}}$, o impeded quarter segments for $\mathrm{V}_{\mathrm{IH}}$, have no visible evidence of dust ("No" for $\mathrm{VDD}_{\mathrm{DD}}$ ), and have no visible evidence of thermokarst ("No" for $\mathrm{V}_{\mathrm{TK}}$ ). 
Figure 76. WAA2 located in a riverine wetland, and WAA3 located in a flats wetland.

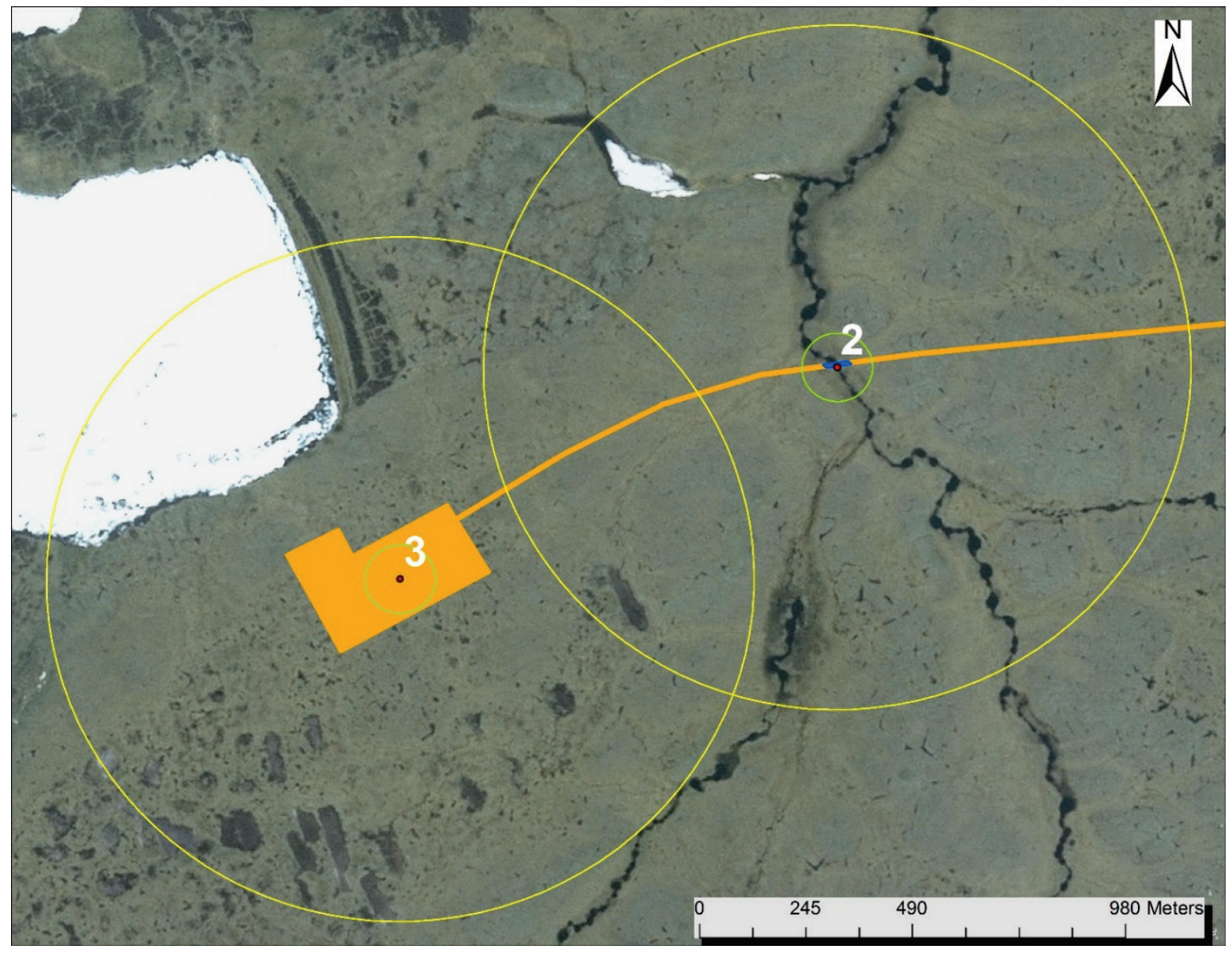

At the $800 \mathrm{~m}$ scale (Figure 76), WAA2 and WAA3 each contain $0 \% \mathrm{~V}_{\mathrm{LD}}$, o impeded quarter segments for $\mathrm{VIW}_{\mathrm{IW}}$, and are located greater than $800 \mathrm{~m}$ from the nearest roadway $\left(\mathrm{V}_{\mathrm{DR}}\right)$. The values for each variable assessed at the $80 \mathrm{~m}$ and $800 \mathrm{~m}$ scale are used to determine variable subindex scores using the wetland assessment calculator (Figure 77).

The variable subindex scores are used to calculate the habitat assessment score, hydrology assessment score, and the biogeochemical cycling assessment score.

\section{Habitat Assessment Score}

The habitat assessment score is the minimum value of $V_{I W}$ and $V_{D R}$, plus the sum of $V_{L D}$ and $V_{L L D}$, divided by two, with the resulting quotient divided by two.

$$
\left[M I N\left(V_{I W}, V_{D R}\right)+\left(\left(V_{L D}+V_{L L D}\right) / 2\right)\right] / 2 \rightarrow[M I N(1,1)+((1+1) / 2)] / 2=1.00
$$


Figure 77. Example of summary of assessment scores for WAA2 generated using the wetland assessment calculator. Though it is located in a different HGM class, WAA3 would receive the same scores as WAA2.

\begin{tabular}{|c|c|c|c|}
\hline \multicolumn{4}{|c|}{ ALASKA NORTH SLOPE REGION RAPID WETLAND ASSESSMENT } \\
\hline \multicolumn{4}{|c|}{ Section C: Summary of Assessment Scores } \\
\hline \multicolumn{4}{|c|}{ On-Site Variable Subindex Scores } \\
\hline $\mathrm{V}_{\mathrm{MT}}$ & Microtopography & & \\
\hline $\mathrm{V}_{\mathrm{SR}}$ & Average species richness & & \\
\hline$V_{\mathrm{BG}}$ & Average percent bare ground & & \\
\hline$V_{\mathrm{LDD}}$ & Local evidence of dust deposition & & \\
\hline$V_{\text {LTK }}$ & Local evidence of thermokarst & & \\
\hline \multicolumn{4}{|c|}{ Off-Site Variable Subindex Scores } \\
\hline $\mathrm{V}_{\mathrm{LLD}}$ & Local landscape disturbance & 1.00 & \\
\hline$V_{\text {SW }}$ & Anthropogenically derived surface water & 1.00 & \\
\hline $\mathrm{V}_{\mathrm{IH}}$ & Impediment to hydrology & 1.00 & \\
\hline $\mathrm{V}_{\mathrm{DD}}$ & Evidence of dust & No & \\
\hline$V_{\mathrm{LD}}$ & Landscape disturbance & 1.00 & \\
\hline$V_{\text {IW }}$ & Impediment to wildlife & 1.00 & \\
\hline$V_{D R}$ & Distance to roadway & 1.00 & \\
\hline $\mathrm{V}_{\mathrm{TK}}$ & Evidence of Thermokarst & No & \\
\hline \multicolumn{4}{|c|}{ Assessment Scores } \\
\hline \multirow{2}{*}{\multicolumn{2}{|c|}{$\begin{array}{r}\text { Habitat } \\
\text { Hydrology }\end{array}$}} & 1.00 & \\
\hline & & 1.00 & \\
\hline \multirow{2}{*}{\multicolumn{2}{|c|}{$\begin{array}{l}\text { Biogeochemical } \\
\text { On-site Modifer }\end{array}$}} & 1.00 & \\
\hline & & & \\
\hline & AVERAGE SCORE & 1.00 & \\
\hline
\end{tabular}

\section{Hydrology Assessment Score}

The hydrology assessment score is the sum of $\mathrm{V}_{\mathrm{IH}}$ and $\mathrm{V}_{\mathrm{sw}}$, divided by two, multiplied by the sum of $\mathrm{V}_{\mathrm{LD}}$ and $\mathrm{V}_{\mathrm{LLD}}$, divided by two, with the resulting product raised to the $1 / 2$ power.

$$
\left[\left(\left(V_{I H}+V_{S W}\right) / 2\right) X\left(\left(V_{L D}+V_{L L D}\right) / 2\right)\right]^{1 / 2} \rightarrow[((1+1) / 2) X((1+1) / 2)]^{1 / 2}=1.00
$$


Biogeochemical Cycling Assessment Score

The biogeochemical cycling assessment score is the minimum value of $\mathrm{V}_{\mathrm{LD}}$ and VLLD.

$$
\operatorname{MIN}\left(V_{L D}, V_{L L D}\right) \rightarrow \operatorname{MIN}(1,1)=1.00
$$

Average Assessment Score

The average pre-project assessment score is the average of the habitat, hydrology, and biogeochemical cycling scores.

$$
(1.0+1.00+1.00) / 3=1.00
$$

If the project results in conversion of land from jurisdictional wetlands to uplands, the post-project assessment score will always be zero.

The resulting value can be incorporated into the Alaska District's CDM.

\subsection{Scenario 3 - Assessment of preservation-only mitigation}

The following is an example scenario that demonstrates the evaluation of a preservation-only mitigation parcel using the pre-project (with preservation) and post-project (without preservation). This parcel has been deemed to meet the preservation criteria and has been identified as a high priority using a watershed approach (33 CFR 332.3(h)). This scenario utilizes desktop (off-site) assessment variables only.

An umbrella mitigation bank proposes to preserve a large parcel within the ACP in order to provide compensatory mitigation to offset impacts to aquatic resources from the Department of the Army permits in the service area identified in the bank's approved Instrument. The mitigation sponsor submitted a mitigation plan that offered to develop additional oil and gas infrastructure as the threat of destruction or adverse modification to the aquatic functions present on the parcel.

An evaluation of existing oil and gas projects in the watershed suggests that the construction of a $600 \mathrm{~m} \times 200 \mathrm{~m}$ well-pad and an attendant road connecting the project to the existing road system is reasonable and likely to occur on the subject parcel. The construction of a $600 \mathrm{~m} \times 200 \mathrm{~m}$ 
(12 ha) well-pad and a $1000 \mathrm{~m} \times 6 \mathrm{~m}$ (o.6 ha) access road were interpolated onto the subject parcel and the resulting effects of disturbance, hydrology disruption, thermokarst, and anthropogenic surface water was predicted (Figure 78).

Figure 78. Parcel boundary and projected footprint of well-pad and access road, as identified in mitigation plan.

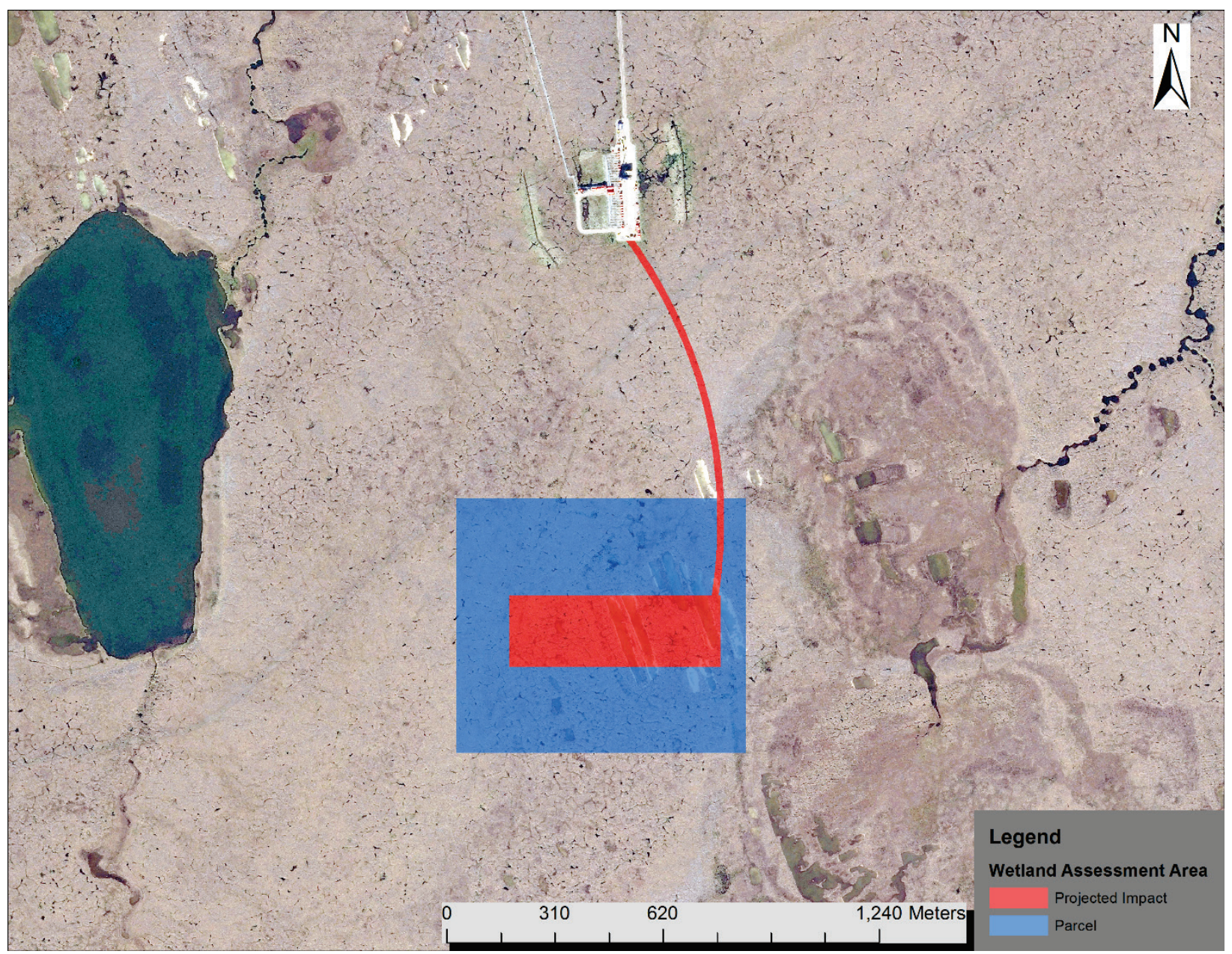

The existing state of the parcel is considered to be undisturbed, which is best described as a flats wetland HGM class.

\subsubsection{WAA1 and WAA2 pre-project assessment (WAA1 ${ }_{\text {PRE }}$ and WAA2PRE)}

The pre-project assessment is performed first, by evaluating the parcel in its "with preservation" condition, which in this case is the existing or current condition. For this step, the score for WAA1PRE and WAA2PRE will be the same since the "with preservation" state is anticipated to be the same, an undisturbed flats wetland. 
At the $80 \mathrm{~m}$ scale (Figure 79), WAA1PRE and WAA2PRE contain O\% $\mathrm{V}_{\mathrm{LLD}}$, $\mathrm{o} \% \mathrm{Vsw}$, o impeded quarter segments for $\mathrm{V}_{\mathrm{IH}}$, and has no visible evidence of dust ("No" for VDD) or thermokarst ("No" for VTK).

At the $800 \mathrm{~m}$ scale (Figure 79), WAA1PRE and WAA2PRE contain O\% $\mathrm{V}_{\mathrm{LD}}$, o impeded quarter segments for $\mathrm{V}_{\mathrm{IW}}$, and the nearest roadway is located more than $800 \mathrm{~m}$ from the sample area $\left(\mathrm{V}_{\mathrm{DR}}\right)$. The values for each variable assessed at the $80 \mathrm{~m}$ and $800 \mathrm{~m}$ scale are used to determine variable subindex scores using the wetland assessment calculator (Figure 80).

Figure 79. Location of WAA1 and WAA2 with associated data points

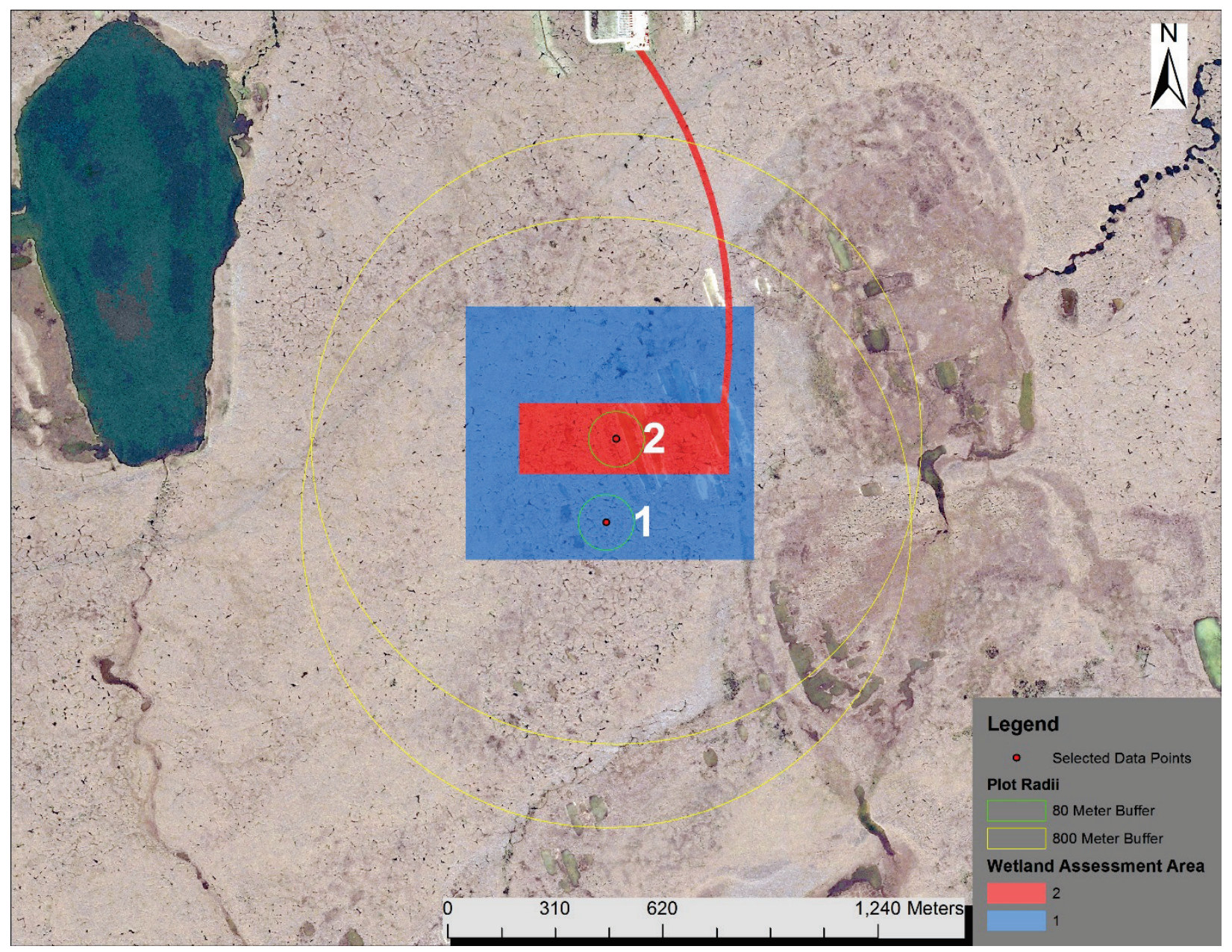


Figure 80. Example of off-site assessment scores for WAA1

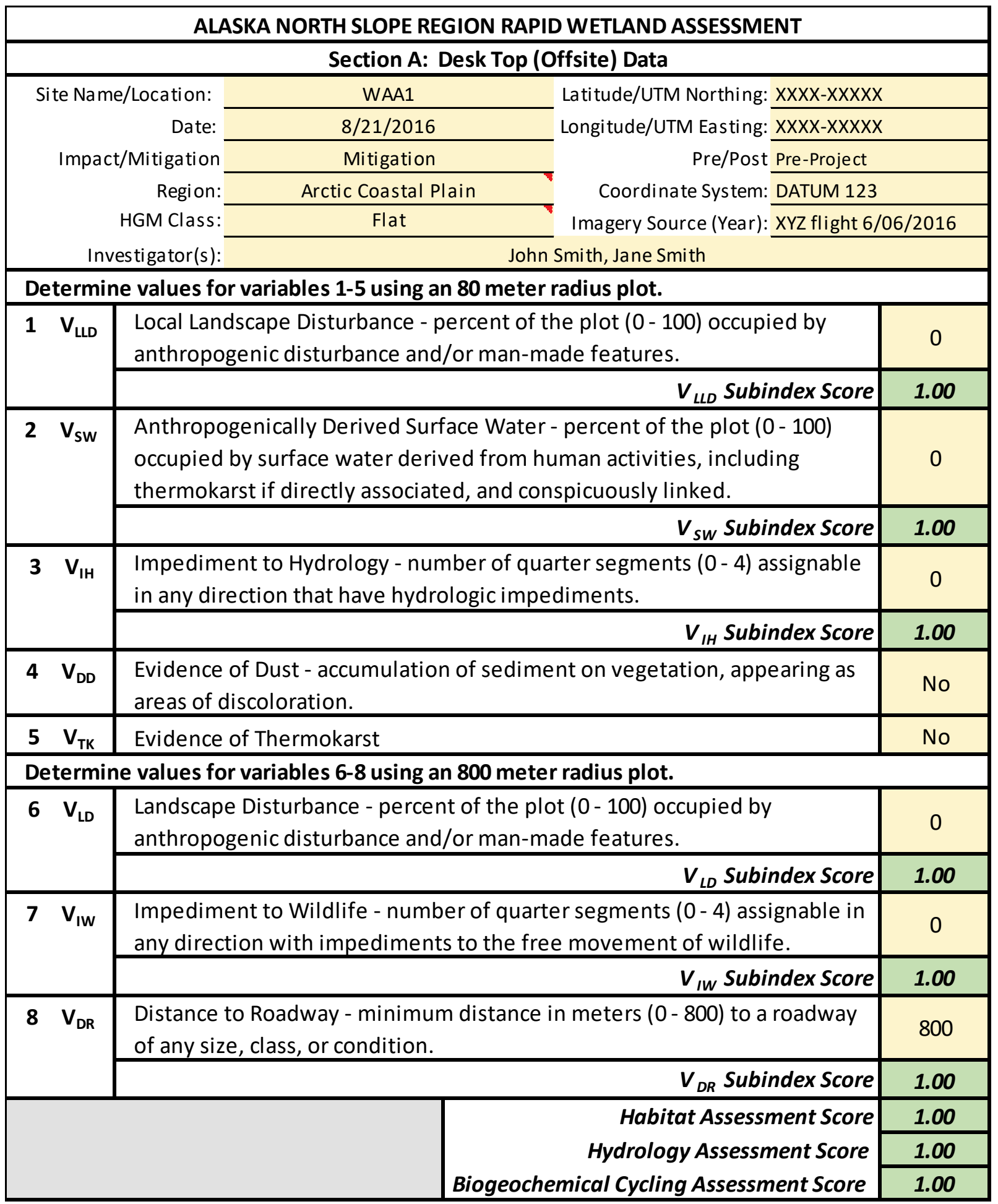

The variable subindex scores are used to calculate the habitat assessment score, hydrology assessment score, and the biogeochemical cycling assessment score. 


\section{Habitat Assessment Score}

The habitat assessment score is the minimum value of $V_{I W}$ and $V_{D R}$, plus the sum of $V_{L D}$ and $V_{L L D}$, divided by two, with the resulting quotient divided by two.

$\left[\operatorname{MIN}\left(V_{I W}, V_{D R}\right)+\left(\left(V_{L D}+V_{L L D}\right) / 2\right)\right] / 2 \rightarrow[\operatorname{MIN}(1.00,1.00)+((1.00+1.00) / 2)] / 2=1.00$

\section{Hydrology Assessment Score}

The hydrology assessment score is the sum of $\mathrm{V}_{\mathrm{IH}}$ and $\mathrm{V}_{\mathrm{SW}}$, divided by two, multiplied by the sum of $\mathrm{V}_{\mathrm{LD}}$ and $\mathrm{V}_{\mathrm{LLD}}$, divided by two, with the resulting product raised to the $1 / 2$ power.

$$
\left[\left(\left(V_{I H}+V_{S W}\right) / 2\right) X\left(\left(V_{L D}+V_{L D}\right) / 2\right)\right]^{1 / 2} \rightarrow[((1.00+1.00) / 2) X((1.00+1.00) / 2)]^{1 / 2}=1.00
$$

Biogeochemical Cycling Assessment Score

The biogeochemical cycling assessment score is the minimum value of $\mathrm{V}_{\mathrm{LD}}$ and VLLD.

$$
\operatorname{MIN}\left(V_{L D}, V_{L L D}\right) \rightarrow \operatorname{MIN}(1.00,1.00)=1.00
$$

Average Assessment Scores

The average assessment score is the average of the habitat, hydrology, and biogeochemical cycling scores: $(1.00+1.00+1.00) / 3=1.00$

\subsubsection{WAA1 post-project assessment (WAA1PosT)}

At the $80 \mathrm{~m}$ scale (Figure 79), WAA1Post would likely contain O\% VLLD, O\% $\mathrm{V}_{\mathrm{sw}}$, no impeded quarter segments for $\mathrm{V}_{\mathrm{IH}}$, and would likely demonstrate visible evidence of dust ("Yes" for $\mathrm{VDD}_{\mathrm{DD}}$ ) and thermokarst ("Yes" for $\mathrm{V}_{\mathrm{TK}}$ ).

At the $800 \mathrm{~m}$ scale (Figure 79), WAA1Post would likely contain $6 \% \mathrm{~V}_{\mathrm{LD}}, 2$ impeded quarter segments for $\mathrm{V}_{\mathrm{IW}}$, and would be located $125 \mathrm{~m}$ from the nearest roadway $\left(\mathrm{V}_{\mathrm{DR}}\right)$. The values for each variable assessed at the $80 \mathrm{~m}$ and $800 \mathrm{~m}$ scale are used to determine variable subindex scores using the wetland assessment calculator (Figure 81). 
Figure 81. Example of summary of assessment scores for WAA1Post generated using the wetland assessment calculator.

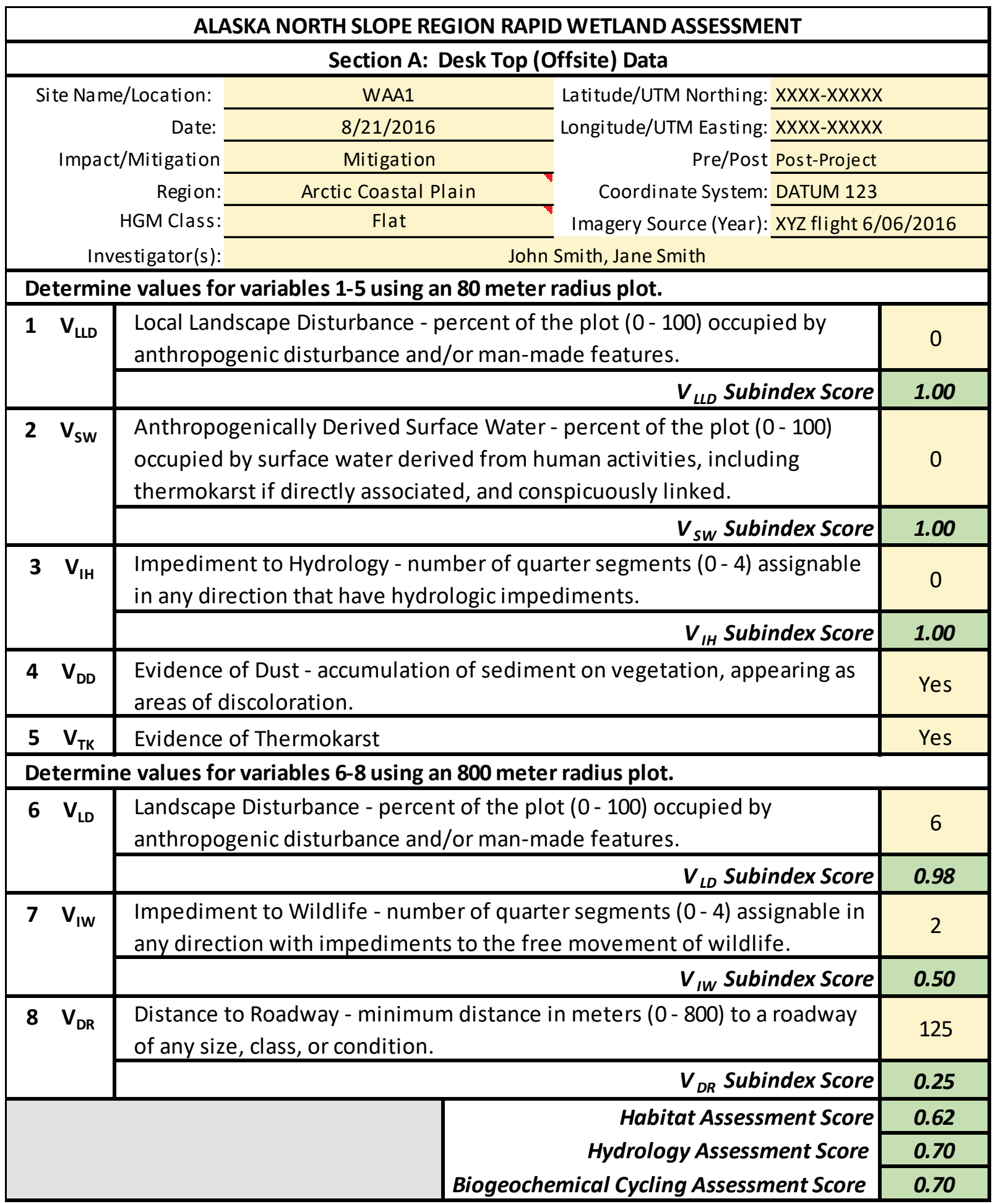

The variable subindex scores are used to calculate the habitat assessment score, hydrology assessment score, and the biogeochemical cycling assessment score. 


\section{Habitat Assessment Score}

The habitat assessment score is the minimum value of $V_{I W}$ and $V_{D R}$, plus the sum of $V_{L D}$ and $V_{L L D}$, divided by two, with the resulting quotient divided by two.

$\left[\operatorname{MIN}\left(V_{I W}, V_{D R}\right)+\left(\left(V_{L D}+V_{L L D}\right) / 2\right)\right] / 2 \rightarrow[\operatorname{MIN}(0.50,0.25)+((0.98+1) / 2)] / 2=0.62$

Because the score in less than 0.7, the Vтк limit does not apply.

\section{Hydrology Assessment Score}

The hydrology assessment score is the sum of $\mathrm{V}_{\mathrm{IH}}$ and $\mathrm{V}_{\mathrm{sw}}$, divided by two, multiplied by the sum of $V_{L D}$ and $V_{L L D}$, divided by two, with the resulting product raised to the $1 / 2$ power.

$$
\left[\left(\left(V_{I H}+V_{S W}\right) / 2\right) X\left(\left(V_{L D}+V_{L L D}\right) / 2\right)\right]^{1 / 2} \rightarrow[((1+1) / 2) X((0.98+1) / 2)]^{1 / 2}=0.70
$$

Biogeochemical Cycling Assessment Score

The biogeochemical cycling assessment score is the minimum value of $V_{L D}$ and VLLD.

$$
\operatorname{MIN}\left(V_{L D}, V_{L L D}\right) \rightarrow \operatorname{MIN}(0.98,0.98)=0.70
$$

The variable subindex scores are used to calculate the habitat assessment score, hydrology assessment score, and the biogeochemical cycling assessment score. Because evidence of thermokarst ( $\left.\mathrm{V}_{\mathrm{TK}}\right)$ is present, the three assessment component scores are limited to a maximum value of 0.7 .

\section{Average Assessment Score}

The average assessment score is the average of the habitat, hydrology, and biogeochemical cycling scores.

$$
(0.62+0.70+0.70) / 3=0.67
$$




\subsubsection{WAA2 post-project assessment (WAA2 Post)}

Since the project will result in the conversion of land from jurisdictional wetlands to uplands, the post-project assessment score will be zero.

The resulting values can be incorporated into the Alaska District's CDM to

determine the potential amount of credits the mitigation site can generate. 


\section{Summary}

The sections above outline information required to conduct a rapid wetland assessment within the North Slope of Alaska. This information includes information regarding wetland classification, description of the region and associated ecological resources, assessment variables and assessment equations, protocols, and scenarios to aid users in application. Additionally, a wetland assessment calculator tool has been developed as a companion to this guidebook, which provides automated calculations of all variables and assessment scores. Notably, any rapid assessment method is limited by the quality of data inputs. As a result, users should utilize the best available tools to conduct the assessment. A variety of GIS, database, and imagery tools are available for the region (Appendix A), and the best, most current information should be utilized in the assessment. Further, this assessment approach allows for users to take advantage of on-site data, when available or as directed by USACE, or to operate the assessment based upon desktop (off-site) data only due to the remote nature of the region and the short growing season.

Questions regarding the operation of the wetland assessment should be directed toward the USACE Alaska District - Regulatory Division at 907753-2712; regpagemaster@usace.army.mil. Updates to this methodology may be considered based upon user input, evaluation of additional data, or other factors to further refine and improve rapid assessment approaches in the region. 


\section{References}

Alaska Dept. of Fish and Game (ADFG). 2006. Our wealth maintained: A strategy for conserving Alaska's diverse wildlife and fish resources. Juneau, AK: Alaska Department of Fish and Game.

Bailey R. G. 1995. Description of the ecoregions of the United States. USDA Forest Service Miscellaneous Publication 1391. Washington, DC: U.S. Forest Service.

Berendse, F., and S. Jonasson. 1992. Nutrient use and nutrient cycling in northern ecosystems. In Arctic ecosystems in a changing climate: An ecophysiological perspective, eds. F. S. Chapin III, R. L. Jefferies, J. F. Reynolds, G. R. Shaver, J. S. Svoboda, and E. W. Chu, 337-356. New York, NY: Academic Press, Inc.

Berkowitz, J. F., C. V. Noble, E. A. Summers, J. R. White, and R. D. DeLaune. 2014. Investigation of biogeochemical functional proxies in headwater streams across a range of channel and catchment alterations. Environmental Management 53(3): 534-548.

Boelman, N. T., L. Gough, J. Wingfield, S. Goetz, A. Asmus, H. E. Chmura, J. S. Krause, J. H. Perez, S. K. Sweet, and K. C. Guay. 2015. Greater shrub dominance alters breeding habitat and food resources for migratory songbirds in Alaskan arctic tundra. Global Change Biology 21(4): 1508-1520.

Bormann, F. H., and G. E. Likens. 1970. The nutrient cycles of an ecosystem. Scientific American 223(4): 92-101.

Bridgham, S. D., C. L Ping, J. L. Richardson, and K. Updegraff. 2001. Soils of Northern Peatlands: Histosols and Gelosols. In Wetland soils: genesis, hydrology, and classification, eds. J. L Richardson and M. J. Vepraskas, 343-370. Boca Raton, FL: CRC Press.

Brinson, M. M. 1993. A hydrogeomorphic classification for wetlands. Wetlands Research Program Technical Report WRP-DE-4. Vicksburg, MS: U.S. Army Engineer Waterways Experiment Station.

Buol, S. W., R. J. Southard, R. C. Graham, and P. A. McDaniel. 2006. Soil genesis and classification, $6^{\text {th }}$ Edition. Sussex, United Kingdom: John Wiley and Sons.

Chapin, III, F. S., N. Fetcher, K. Kielland, K. R. Everett, and A. E. Linkins. 1993. Productivity and nutrient cycling of Alaskan tundra: Enhancement by flowing soil water. Ecology 69: (3)693-702.

Cowardin, L. M., V. Carter, F. C. Golet, and E. T. LaRoe. 1979. Classification of wetlands and deepwater habitats of the United States. Washington, DC: U.S. Department of the Interior, Fish and Wildlife Service.

Croonquist, M. J., and R. P. Brooks. 1991. Use of avian and mammalian guilds as indicators of cumulative impacts in riparian wetland areas. Environmental Management 15(5): 701-714. 
Davis, N. 2001. Permafrost: A guide to frozen ground in transition. Fairbanks, AK: University of Alaska Press.

Frey, K. E., and J. W. McClelland. 2009. Impacts of permafrost degradation on arctic river biogeochemistry." Hydrological Processes 23(1): 169-182.

Furness, R. W., and J. J. D. Greenwood. 1993. Birds as monitors of environmental change. New York, NY: Springer Science + Business Media.

Gallant, A. L., E. F. Binnian, J. M. Omernik, and M. B. Shasby. 1995. Ecoregions of Alaska. U.S. Geological Survey Professional Paper 1567. Washington, DC: United States Government Printing Office.

Giblin, A. E., K. J. Nadelhoffer, G. R. Shaver, J. A. Laundre, and A. J. McKerrow. 1991. Biogeochemical diversity along a riverside toposequence in arctic Alaska. Ecological monographs 61(4): 415-435.

Hammerschmidt, C. R., W. F. Fitzgerald, C. H. Lamborg, P. H. Balcom, and C.-M. Tseng. 2006. Biogeochemical cycling of methylmercury in lakes and tundra watersheds of Arctic Alaska. Environmental Sci. Technol. 4O(4): 1204-1211.

Johnson, S. R., and D. R. Herter. 1989. The birds of the Beaufort Sea. Anchorage, AK: British Petroleum Exploration.

Jonasson, S., A. Michelsen, and I. K. Schmidt. 1999. Coupling of nutrient cycling and carbon dynamics in the Arctic, integration of soil microbial and plant processes. Applied Soil Ecology 11(2-3): 135-146.

Jonasson, S., and G. R. Shaver. 1999. Within-stand nutrient cycling in arctic and boreal wetlands. Ecology 80(7): 2139-2150.

Jorgenson, M. T., J. E. Roth, P. F. Miller, M. J. Macander, M. S. Duffy, A. F. Wells, G. V. Frost, and E. R. Pullman. 2009. An ecological land survey and landcover map of the Arctic Network. Natural Resource Technical Report NPS/ARCN/NRTR2009/270. Fort Collins, CO: U.S. National Park Service, Natural Resource Program Center.

Kessel, B. 1979. Avian habitat classification for Alaska. The Murrelet 6o(3): 86-94.

Liebezeit, J. R., S. J. Kendall, S. Brown, C. B. Johnson, P. Martin, T. L. McDonald, D. C. Payer C. L. Rea, B. Steever, A. M. Wildman, and S. Zack. 2009. Influence of human development and predators on nest survival of tundra birds, Arctic Coastal Plain, Alaska. Ecological Applications 19(6): 1628-1644.

Mack, M. C., E. A. G. Schuur, M. Syndonia Bret-Harte, G. R. Shaver, and F. S. Chapin,III. 2004. Ecosystem carbon storage in arctic tundra reduced by long-term nutrient fertilization. Nature 431(7007): 440-443.

Markon, C.J. 2001. Seven-year phenological record of the Alaskan ecoregions derived from advanced very high resolution radiometer normalized difference vegetation index data. Open-File Report 01-11. Washington, DC: U.S. Department of the Interior, U.S. Geological Survey. 
McGuire, A. D., L. G. Anderson, T. R. Christensen, S. Dallimore, L. Guo, D. J. Hayes, M. Heimann, T. D. Lorenson, R. W. Macdonald, and N. Roulet. 2009. Sensitivity of the carbon cycle in the Arctic to climate change. Ecological Monographs 79(4): 523-555.

McNamara, J. P., D. L. Kane, and L. D. Hinzman. 1998. An analysis of streamflow hydrology in the Kuparuk River Basin, Arctic Alaska: A nested watershed approach. Journal of Hydrology 206(1-2): 39-57.

Mitsch, W. J., and J. G. Gosselink. 2007. Wetlands. 4th edition. New York, NY: John Wiley \& Sons.

Morrison, M. L. 1986. Bird populations as indicators of environmental change. Current Ornithology 3: 429-451.

Nellemann, C., I. Vistnes, P. Jordhøy, O. Strand, and A. Newton. 2003. Progressive impact of piecemeal infrastructure development on wild reindeer. Biological Conservation 113(2): 307-317.

Noble, C. V., E. A. Summers, and J. F. Berkowitz. 2014. Validating the operational draft regional guidebook for the functional assessment of high-gradient ephemeral and intermittent headwater streams. ERDC/EL TR-14-7. Vicksburg, MS: U.S. Army Engineer Research and Development Center.

Noble, C. V., and J. F. Berkowitz. 2016. Wetland soils and the hydrogeomorphic classification of wetlands. In Wetland soils: Genesis, hydrology, landscapes, and classification, $2^{\text {nd }}$ edition, M. J. Vepraskas and C. B. Craft, 393-424. Boca Raton, FL: CRC Press.

North Slope Science Initiative (NSSI). 2013. North Slope Science Initiative (NSSI) Landcover Mapping Summary Report. Rancho Cordova, CA: Ducks Unlimited, Inc.

Ralph, C. J., G. R. Geupel, P. Pyle, T. E. Martin, and D. F. DeSante. 1993. Handbook of field methods for monitoring landbirds. General Technical Report PSW-GTR144-Web. Albany, CA: U.S. Department of Agriculture, Forest Service, Pacific Southwest Research Station.

Reddy, K. R., and R. D. DeLaune. 2008. Biogeochemistry of wetlands: Science and applications. Boca Raton, FL: CRC press.

Roulet, N. T., and M-K Woo. 1986. Hydrology of a wetland in the continuous permafrost region. Journal of Hydrology 89(1-2): 73-91

Rovansek, R. J., L. D. Hinzman, and D. L. Kane. 1996. Hydrology of a tundra wetland complex on the Alaskan Arctic Coastal Plain, USA. Arctic and Alpine Research 28(3): 311-317.

Schuur, E. A. G., J. Bockheim, J. G. Canadell, E. Euskirchen, C. B. Field, S. V. Goryachkin, S. Hagemann, P. Kuhry, P. M. Lafleur, H. Lee, G. Mazhitova, F. E. Nelson, A. Rinke, V. E. Romanovsky, N. Shiklomanov, C. Tarnocai, S. Venevsky, J. G. Vogel, and S. A. Zimov. 2008. Vulnerability of permafrost carbon to climate change: implications for the global carbon cycle. BioScience 58(8): 701-714. 
Shafer, D., and D. J. Yozzo. 1998. National guidebook for application of hydrogeomorphic assessment to tidal fringe wetlands. Wetlands Research Program TR WRP-DE-16. Vicksburg, MS: U.S. Army Engineer Waterways Experiment Station.

Shaver, G. R., and F. S. Chapin, III. 1991. Production: biomass relationships and element cycling in contrasting arctic vegetation types." Ecological Monographs 61(1): 131.

Shaver, G. R., W. D. Billings, F. Chapin, III, A. E. Giblin, K. J. Nadelhoffer, W. C. Oechel, and E. B. Rastetter. 1992. Global change and the carbon balance of arctic ecosystems. BioScience 42(6): 433-441.

Smith, R. D., A. Ammann, C. Bartoldus, and M. M. Brinson. 1995. An approach for assessing wetland functions using hydrogeomorphic classification, reference wetlands, and functional indices. Wetlands Research Program Technical Report WRP-DE-9. Vicksburg, MS: U.S. Army Engineer Waterways Experiment Station.

Smith, R. D, C. V. Noble, and J. F. Berkowitz. 2013. Hydrogeomorphic (HGM) approach to assessing wetland functions: Guidelines for developing guidebooks (version 2). ERDC/EL TR-13-11. Vicksburg, MS: U.S. Army Engineer Research and Development Center.

Sullivan, P. F., S. J. T. Arens, R. A. Chimner, and J. M. Welker. 2008. Temperature and microtopography interact to control carbon cycling in a high arctic fen. Ecosystems 11(1): 61-76.

Summers, E., C. V. Noble, and J. F. Berkowitz. 2017. Operational draft regional guidebook for the functional assessment of high-gradient headwater streams and low-gradient perennial streams in Appalachia. ERDC/EL TR-17-1. Vicksburg, MS: U. S Army Engineer Research and Development Center.

Summers, E., J. F. Berkowitz, C. V. Noble, and F. Spilker. 2015. Evaluating a rapid assessment method using salamander community metrics. Wetland Science and Practice 32(4): 9-14.

U.S. Army Corps of Engineers. 2007. Regional Supplement to the Corps of Engineers Wetland Delineation Manual: Alaska Region (Version 2.o). ERDC/EL TR-0724. Vicksburg, MS: U.S. Army Engineer Research and Development Center.

U.S. Department of Agriculture, Natural Resources Conservation Service (USDA NRCS). 2006. Land Resource Regions and Major Land Resource Areas of the United States, the Caribbean, and the Pacific Basin. U.S. Department of Agriculture Handbook 296. Washington, D.C.: U.S. Department of Agriculture.

U.S. Department of Agriculture, Natural Resources Conservation Service (USDA NRCS). 2004. Land resource regions and major land resource areas of Alaska. Palmer, AK: United States Department of Agriculture-NRCS.

U.S. Department of the Interior - Bureau of Land Management (USDOI-BLM). 2012. National Petroleum Reserve-Alaska final Integrated Activity Plan/ Environmental Impact Statement. Anchorage, AK: U.S. Department of the Interior, Bureau of Land Management. 
Viereck, L. A., C. T. Dyrness, A. R. Batten, and K. J. Wenzlick. 1992. The Alaska vegetation classification. Gen. Tech. Rep. PNW-GTR-286. Portland, OR: U.S. Department of Agriculture, Forest Service, Pacific Northwest Research Station.

Wahrhaftig, C. 1965. Physiographic divisions of Alaska. Geological Survey Professional Paper 482. Washington, DC: U.S. Department of the Interior.

Walker, D. A., and K. R. Everett. 1987. Road dust and its environmental impact on Alaskan taiga and tundra. Arctic and Alpine Research 19(4): 479-489.

Woo, M-K., and K. L. Young. 2006. High Arctic wetlands: Their occurrence, hydrological characteristics and sustainability. Journal of Hydrology 320(3-4): 432-450.

Woo, M-K., and T. C. Winter. 1993. The role of permafrost and seasonal frost in the hydrology of northern wetlands in North America. Journal of hydrology 141(14): 5-31. 


\section{Appendix A: Resources for Wetland Classification, Assisting in Site Characterization, and Conducting Off-Site Analysis of Wetlands within the North Slope Region}

A hydrogeomorphic classification for wetlands (Brinson 1993). http://www.dtic.mil/docs/citations/ADA270053

Hydrogeomorphic (HGM) Approach to assessing wetland functions:

Guidelines for developing guidebooks (Version 2) (Smith et al. 2013). http://www.dtic.mil/docs/citations/ADA583904

North Slope Science Catalog- North Slope Science Initiative (NSSI 2013) http://catalog.northslope.org/catalog

Over 80 datasets available for North Slope Alaska, including:

- Digital Elevation Models (DEMs)

- Permafrost and ground-ice characterization

- NSSI Landcover (30 m resolution)

- National Hydrology Datasets

- Climate Datasets

- LANDFIRE Existing Vegetation Type Maps

- Snow cover and Ice Analyses (freeze and thaw depths)

- Unified Ecoregions of Alaska

Geographical Information Network of Alaska-GINA http://gina.alaska.edu/data

A host of GIS data layers including, but not limited to:

- Advanced Very High Resolution Radiometer (AVHRR)

- MODIS and Landsat satellite images

- Digital Elevation Models (DEM's)

Toolik Field Station Spatial Data. http://toolik.alaska.edu/gis/data/ 
The Toolik Field station develops, archives, and distributes spatial data applicable for research in the Toolik Region. The Toolik Field Station archives an assortment of GIS and remote sensing datasets including:

- Digital Elevation Models (DEMs) (high-resolution for selected localities)

- Landscape Disturbance

- Assortment of Satellite and Aerial imagery

- Landscape Hydrology

Alaska DNR-Division of Oil and Gas: GIS Data Downloads

http://dog.dnr.alaska.gov/GIS/GISDataFiles.htm

Oil and gas GIS data including leases, units, and participating areas in Alaska.

USGS (formerly available via Alaska Geospatial Data Clearinghouse (AGDC))

Available at http://catalog.data.gov/dataset and https://www.sciencebase.gov/catalog

Example datasets include:

- Land Surface Characterization for Alaska and Arctic Regions

- Water Resources of Alaska GIS Data

- Digital Elevation Models

- Statewide Geologic Maps for Alaska 


\section{Appendix B: Data Form}




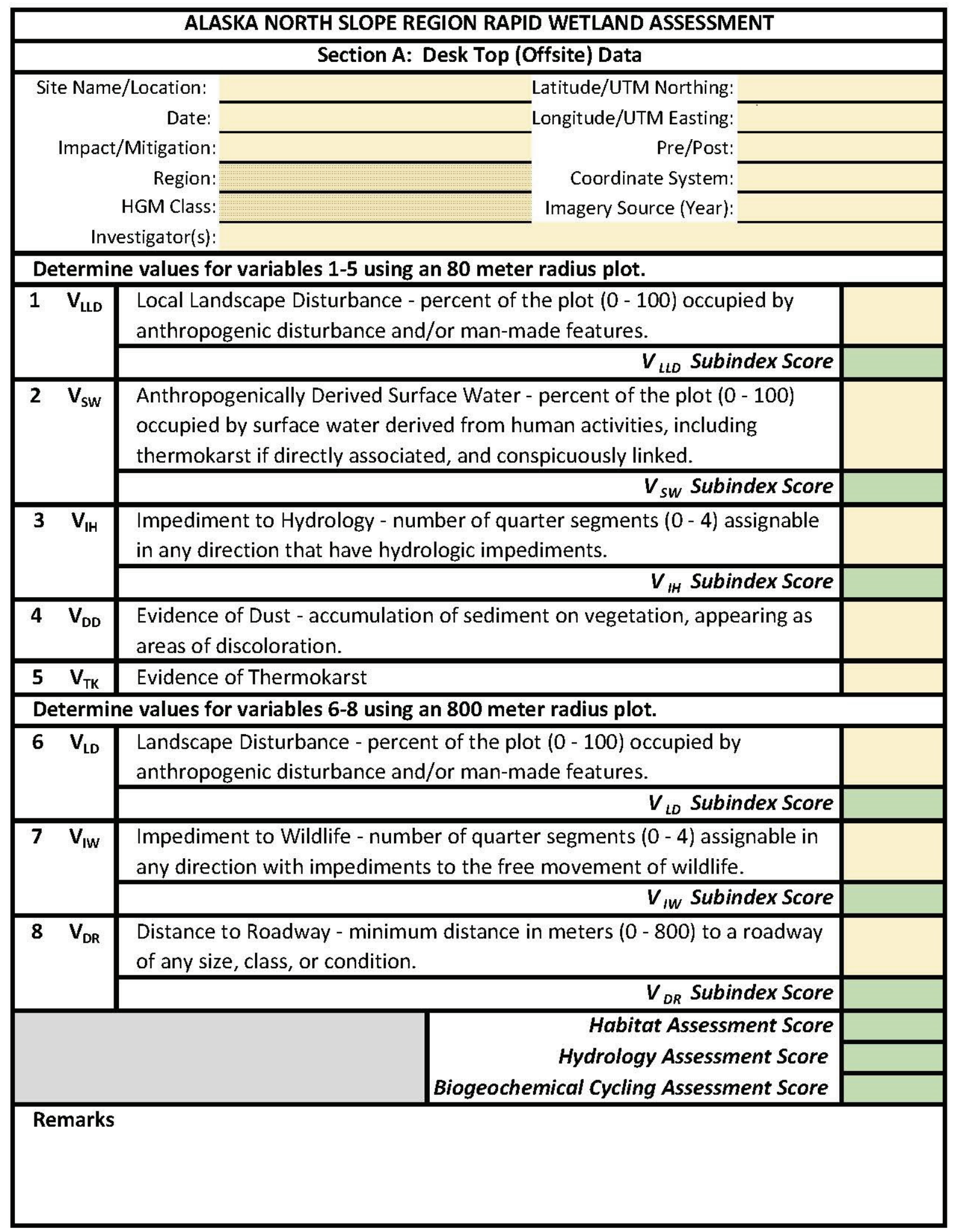




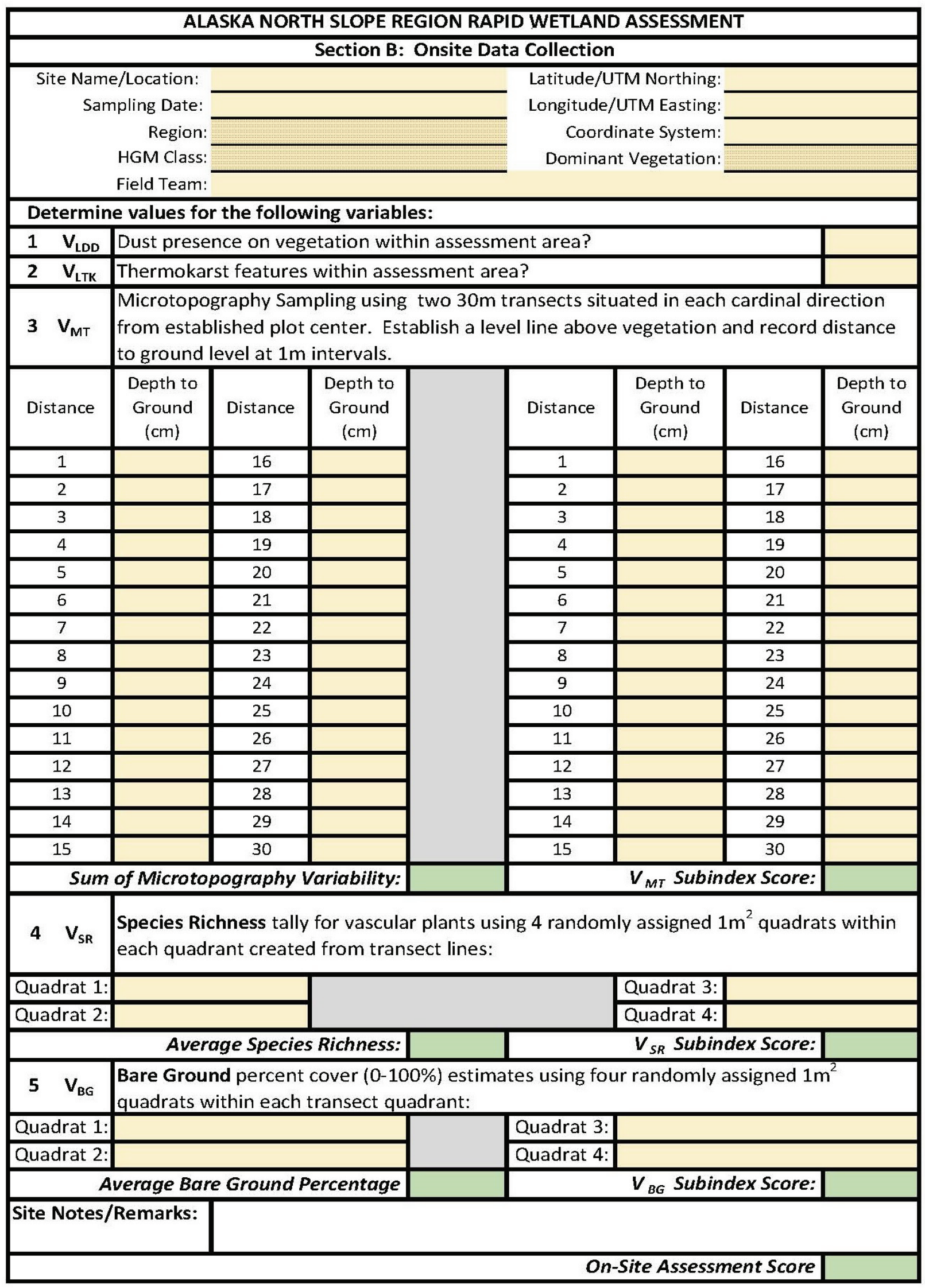




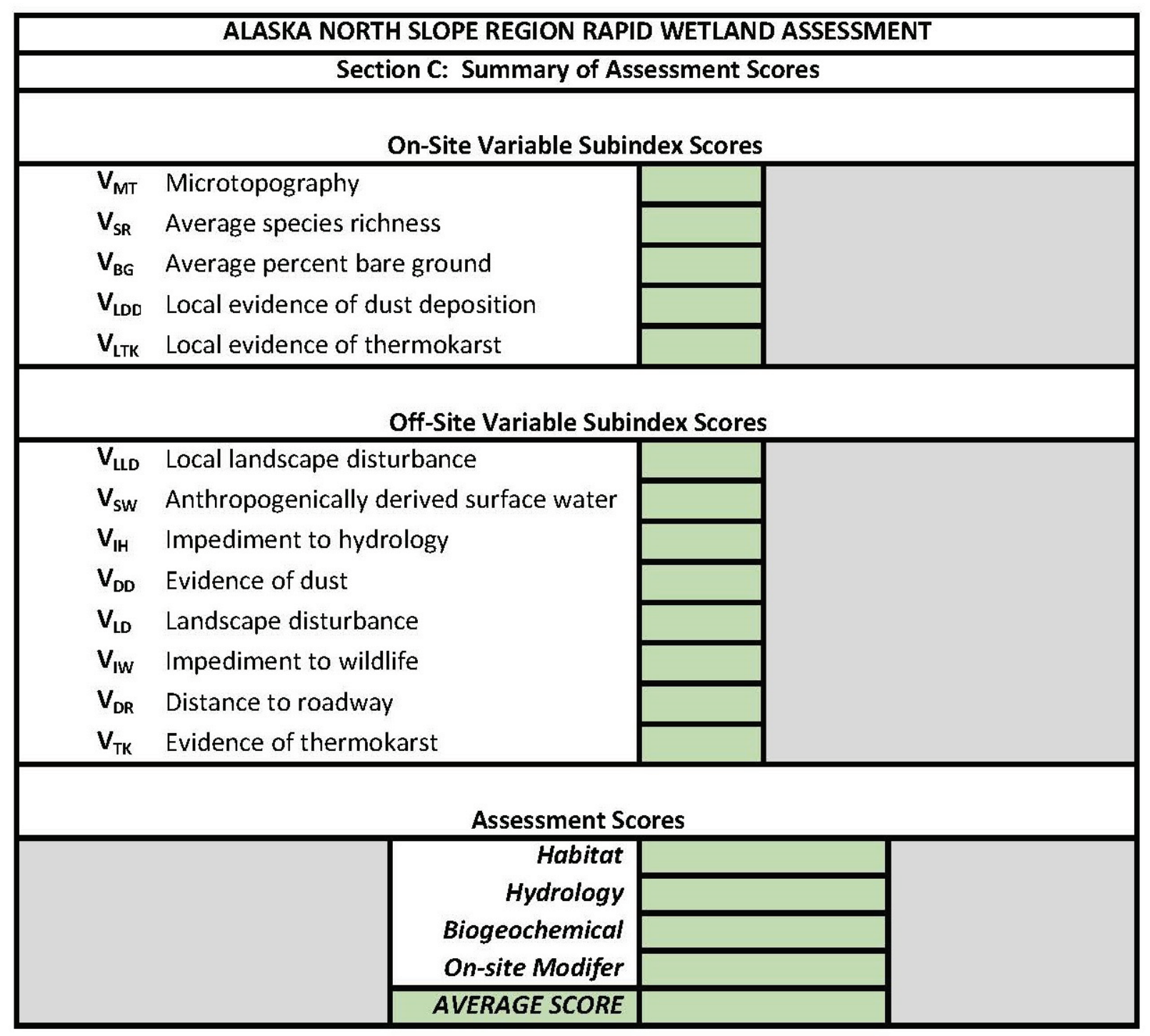


The public reporting burden for this collection of information is estimated to average 1 hour per response, including the time for reviewing instructions, searching existing data sources, gathering and maintaining the data needed, and completing and reviewing the collection of information. Send comments regarding this burden estimate or any other aspect of this collection of information, including suggestions for reducing the burden, to Department of Defense, Washington Headquarters Services, Directorate for Information Operations and Reports (0704-0188), 1215 Jefferson Davis Highway, Suite 1204, Arlington, VA 22202-4302. Respondents should be aware that notwithstanding any other provision of law, no person shall be subject to any penalty for failing to comply with a collection of information if it does not display a currently valid OMB control number. PLEASE DO NOT RETURN YOUR FORM TO THE ABOVE ADDRESS.

\begin{tabular}{|l|l|l}
\hline $\begin{array}{l}\text { 1. REPORT DATE }(D D-M M-Y Y Y Y) \\
\text { August } 2017\end{array}$ & $\begin{array}{l}\text { 2. REPORT TYPE } \\
\text { Technical Report }\end{array}$ & 3. DATES COVERED (From - To) \\
\hline
\end{tabular}

\section{TITLE AND SUBTITLE}

Operational Draft Regional Guidebook for the Rapid Assessment of

Wetlands in the North Slope Region of Alaska 5a. CONTRACT NUMBER

5b. GRANT NUMBER

5c. PROGRAM ELEMENT NUMBER

5d. PROJECT NUMBER

A1210-North Slope Alaska

5e. TASK NUMBER

5f. WORK UNIT NUMBER

8. PERFORMING ORGANIZATION REPORT NUMBER

ERDC/EL TR-17-14

10. SPONSOR/MONITOR'S ACRONYM(S)

WRAP

11. SPONSOR/MONITOR'S REPORT NUMBER(S)

\section{DISTRIBUTION/AVAILABILITY STATEMENT}

Approved for public release; distribution is unlimited.

\section{SUPPLEMENTARY NOTES}

\section{ABSTRACT}

This guidebook describes a rapid approach to assessing wetlands within the Arctic Foothills and Arctic Coastal Plain (North Slope) region of Alaska. This report utilized established approaches to (1) characterize regional wetlands, (2) provide the rationale used to determine assessment scores, (3) describe assessment variables utilized, (4) outline the developed assessment equations, and (5) provide a step-by-step protocol for applying results. The region's remote nature and short growing season limits the time period during which onsite data can be collected. As a result, the developed method allows for a tiered approach utilizing (1) an assessment based upon off-site data (remotely sensed or desktop resources) only or (2) an assessment using a combination of on-site (field data collection) and off-site data collection. On-site data collection may be required at the discretion of USACE. Several scenarios are presented to aid users in conducting the rapid wetland assessment.

\section{SUBJECT TERMS}

Assessment

Biogeochemical cycling

Habitat

\begin{tabular}{|c|c|c|c|}
\hline \multicolumn{3}{|c|}{ 16. SECURITY CLASSIFICATION OF: } & \multirow{3}{*}{$\begin{array}{l}\text { 17. LIMITATION OF } \\
\text { ABSTRACT } \\
\text { UNCLASSIFIED }\end{array}$} \\
\hline a. REPORT & b. ABSTRACT & c. THIS PAGE & \\
\hline UNCLASSIFIED & UNCLASSIFIED & UNCLASSIFIED & \\
\hline
\end{tabular}

North Slope Region

Rapid wetland assessment 